\title{
Characterization and recommendations for the remediation of acid mine drainage impacted streams
}

\author{
Patrick F. Hudnall \\ West Virginia University
}

Follow this and additional works at: https://researchrepository.wvu.edu/etd

\section{Recommended Citation}

Hudnall, Patrick F., "Characterization and recommendations for the remediation of acid mine drainage impacted streams" (2003). Graduate Theses, Dissertations, and Problem Reports. 1379.

https://researchrepository.wvu.edu/etd/1379

This Thesis is protected by copyright and/or related rights. It has been brought to you by the The Research Repository @ WVU with permission from the rights-holder(s). You are free to use this Thesis in any way that is permitted by the copyright and related rights legislation that applies to your use. For other uses you must obtain permission from the rights-holder(s) directly, unless additional rights are indicated by a Creative Commons license in the record and/ or on the work itself. This Thesis has been accepted for inclusion in WVU Graduate Theses, Dissertations, and Problem Reports collection by an authorized administrator of The Research Repository @ WVU. For more information, please contact researchrepository@mail.wvu.edu. 
Characterization and Recommendations for the Remediation of Acid Mine Drainage Impacted Streams

Patrick F. Hudnall

Thesis submitted to

The College of Engineering and Mineral Resources

at West Virginia University

In partial fulfillment of the requirements for the degree of

Master of Science

In

Civil and Environmental Engineering

Roger Viadero, Ph.D., Chair

Ronald Fortney, Ph.D.

Donald Gray, Ph.D., P.E.

Department of Environmental Engineering

Morgantown, West Virginia

2003

Keywords: acid mine drainage, remediation, prevention, Appalachian Corridor-H, water quality, Beaver Creek, watershed. 


\begin{abstract}
Characterization and Recommendations for the Remediation of Acid Mine Drainage Impacted Streams
\end{abstract}

Patrick F. Hudnall

The Beaver Creek watershed (located in Tucker Co., in north eastern West Virginia) has been severely impacted by Acid Mine Drainage (AMD) from both historic and current surface mining operations. For this study, water quality sampling sites were designated and monitored along the main channel and several tributaries of Beaver Creek. The water quality was monitored via water quality grab samples, in-situ water quality monitoring devices (YSI Sondes), and fish and macroinvertebrate community sampling. For example, the headwaters of Beaver Creek have limited capacity to buffer changes in $\mathrm{pH}$, as the average alkalinity and average acidity values were 11.1 and 13.8 $\mathrm{mg} / \mathrm{L}$ as $\mathrm{CaCO}_{3}$, respectively, and the average $\mathrm{pH}$ was 5.1. Although a diminished capacity to buffer against changes in $\mathrm{pH}$ was observed, the headwaters of Beaver Creek were relatively un-impacted by AMD. Approximately half way down the drainage, $\mathrm{pH}$ values ranged from 6.1 to 8.9 and the waters were net alkaline due to the periodic addition of limestone sands to Beaver Creek and contributions from other active treatment processes located on tributaries. The water quality of Beaver Creek as it enters the Blackwater River was also measured and was found to be net alkaline with $\mathrm{pH}$ ranging from 5.5 to 7.8. High concentrations of metal ions (Fe, $\mathrm{Mn}, \mathrm{Al}$, and $\mathrm{SO}_{4}$ ) and acidity along with low $\mathrm{pH}$ and alkalinity values were observed in the tributary water quality sampling sites. The water quality data collected from the in-situ monitoring devices and fish and macroinvertebrate sampling supported the findings from the water quality grab sampling. Recommendations were made for the remediation as well as recommendations for the minimization of further impacts, due to roadway construction, of the tributaries sampled during this study. For example, the implementation of rigorous acid-base accounting on all overburden, which may be disturbed during construction, and the development of special handling procedures are recommended. Additionally, the implementation of a "train" of passive treatment processes tailored to meet the specific water quality loading requirements and targeted remediation goals in the Beaver Creek watershed are suggested, with an emphasis on the integration of natural stream design into the treatment process. Recommendations were also made for the reclamation of the headwaters of Beaver Creek to a native trout fishery. 


\section{TABLE OF CONTENTS}

TITLE PAGE $i$

ABSTRACT $\quad$ ii

TABLE OF CONTENTS iii

LIST OF TABLES viii

LIST OF FIGURES $\quad x i$

CHAPTER 1.0 INTRODUCTION 1

1.1 Problem Statement 1

1.2 Objectives 1

CHAPTER 2.0 BACKGROUND 3

2.1 Impacts of Acid Mine Drainage on Stream Water Quality 3

2.1.1 Water Chemistry 3

2.1.2 Macro-invertebrates and Fish Populations 4

2.2 Prevention of Acid Mine Drainage $\quad 7$

2.3 Mitigation and Remediation of Acid Mine Drainage 10

2.3.1 Wetland Treatment Systems $\quad 11$

2.3.2 Anoxic Limestone Drains 15

2.3.3 Open Limestone Channels 16

2.3.4 Sulfur-Reducing Bacteria $\quad 17$

2.3.5 Limestone Sands 18

2.4 Social and Economic Benefits 19

2.5 In-Situ Water Quality Monitoring 20

CHAPTER 3.0 EXPERIMENTAL APPROACH 21 
$\begin{array}{ll}\text { 3.1 Description of Study Site } & 21\end{array}$

$\begin{array}{ll}3.2 \text { Description of Sampling Sites } & 24\end{array}$

3.2.1 Upper Beaver Creek 25

3.2.2 Elder Swamp 25

$\begin{array}{ll}3.2 .3 \text { Gatzmer } & 26\end{array}$

$\begin{array}{ll}\text { 3.2.4 Iron Pond } & 27\end{array}$

3.2.5 Slate Culvert 28

3.2.6 Chaffee Run $\quad 29$

3.2.7 Hawkins Run $\quad 30$

3.2.8 Lower Beaver Creek Watershed Sampling Sites 31

3.2.8.1 Lower Beaver Creek 32

3.2.8.2 Davis

$\begin{array}{ll}\text { 3.3 Materials } & 33\end{array}$

3.4 Sampling Regime $\quad 35$

3.4.1 YSI Sondes $\quad 35$

3.4.2 Grab Samples $\quad 36$

$\begin{array}{ll}3.5 \text { Experimental Methods } & 38\end{array}$

3.5.1 YSI Sondes 38

3.5.2 Grab Sample Water Chemistry $\quad 39$

3.5.3 Benthic Macro Invertebrate and Fish Assessment $\quad 42$

3.5.3.1 Benthic macroinvertebrate Methods 42

3.5.3.2 Fisheries Evaluations Methods $\quad 44$

3.6 Quality Assurance and Quality Control 47 
3.6.2 Grab Samples $\quad 52$

3.7 Statistical Analysis: Paired-t Test 53

CHAPTER 4.0 RESULTS 56

4.1 YSI Sonde Results 56

4.1.1 Upper Beaver Creek (BC-1) 57

4.1.2 Gatzmer (BC-3) 58

4.1.3 Chaffee (BC-7) $\quad 58$

4.1.4 Hawkins $(B C-8) \quad 59$

4.1.5 Lower Beaver Creek/Davis (BC-6 \& 9) 59

$\begin{array}{ll}\text { 4.1.6 Probe Failures } & 60\end{array}$

4.2 Water Quality Grab Sample Results 65

4.2.1 Upper Beaver Creek (BC-1) 66

4.2.2 Elder Swamp (BC-2) 67

$\begin{array}{ll}\text { 4.2.3 Gatzmer (BC-3) } & 68\end{array}$

4.2.4 Iron Pond (BC-4) 69

4.2.5 Slate Culvert (BC-5) 70

$\begin{array}{ll}\text { 4.2.6 Chaffee (BC-7) } & 72\end{array}$

$\begin{array}{ll}\text { 4.2.7 Hawkins (BC-8) } & 73\end{array}$

4.2.8 Lower Beaver Creek (BC-6 and BC-9) 74

4.3 Fish and Macroinvertebrate Sampling Results 75

4.3.1 Upper Beaver Creek (BC-1) 77

$\begin{array}{ll}\text { 4.3.2 Gatmer }(B C-3) & 77\end{array}$ 
CHAPTER 7.0 REFERENCES

APPENDIX A

APPENDIX B 


\section{List of Tables}

TABLE

Table 2.1.2.1.

WVSCI Ranges and Corresponding Stream

7

Ranks (EPA, 1999).

Table 3.3.1. $\quad$ Range and Accuracy of YSI Sonde Probes

35

Employed in the Beaver Creek Watershed.

Table3.4.1.1. YSI Sonde Deployment and Retrieval Dates for

36

Beaver Creek

Table 3.4.2.1. Beaver Creek Watershed Sampling Sites and

37

Dates on Which Water Quality Grab Samples

Were Taken.

Table 3.5.2.1 Methods Used to Determine the Water Quality

40

Parameters.

Table 3.5.3.1.1. Classification of WVSCI Metrics (USEPA 2000).

Table 3.5.3.1.2. The Rating System for WVSCI (USEPA 2000). 44

Table 3.5.3.2.1. Narrative Description of Stream Biological 46

Integrity Associated with each of the IBI Categories, taken from Table 5.5 (Roth et al. 1999).

Table 3.6.1.1. $\quad$ QA/QC on the $\mathrm{pH}$ Values Reported by the YSI

Sondes in the Beaver Creek Watershed.

Table 3.6.1.2. $\quad$ QA/QC on the SpCond Values Reported by the

YSI Sondes in the Beaver Creek Watershed.

Table 3.6.1.3. $\quad$ QA/QC on the Temperature Values Reported by the YSI Sondes in the Beaver Creek Watershed.

Table 3.6.1.4. QA/QC on the Turbidity Values Reported by the YSI Sondes in the Beaver Creek Watershed.

Table 4.1.1. Beginning and Ending Dates of the Seasonal Periods of Sonde Analysis.

Table 4.1.2.

Average and Max. and Min. Values Collected at the Five Beaver Creek Watershed Deployment Sites. 
Table 4.1.6.1.

Sections of Suspected Problematic Data and theReason for Suspicion from BC-1.

Table 4.1.6.2. Sections of Suspected Problematic Data and the Reason

Table 4.1.6.3. Sections of Suspected Problematic Data and the Reason 62 for Suspicion from BC-7.

Table 4.1.6.4. Sections of Suspected Problematic Data and the Reason for Suspicion from BC-8.

Table 4.1.6.5. Sections of Suspected Problematic Data and the Reason 64 for Suspicion from BC-6/9.

Table 4.2.1.

Summary of Standard Water Quality Criteria for 65 Freshwater Organisms (Jenkins et al. 1995).

Table 4.3.1.

Macroinvertebrate Data and Index Scores from Beaver Creek Water Quality Grab Sampling Sites.

Table 4.3.2

Fish Data and Index Scores from Beaver Creek Water 76 Quality Grab Sample Sites.

Table 5.1.1.

Average Water Quality Values from the Beaver

82 Creek Sampling Stations.

Table 5.1.2.

Statistical Analysis Results of BC-1, BC-3, and BC-9

Table 5.2.2.1. Water Chemistry Criteria for the Support of Salmonids and the Average Values Recorded from BC-1 Sampling Site.

Table 5.2.2.2. Initial and Actual Metal Ion Concentrations from BC-1, 89 as Calculated by CHEAQS.

Table 5.2.2.3. Average Values of Flow and Acidity Used to Calculate the Average Annual Acid Load at BC-1.

Table 5.3.1

Average Molar Concentrations of Ions Used to Calculate $\mu_{\text {calc. }} .93$

Table 5.3.2.

Values of $\mu_{\text {meas }}$ and $\mu_{\text {calc }}$ and Percent Difference for the BC-1 and BC-3 Grab Sample Sites. 
Table 5.4.1.1. Average Flow rate Measurements from the BC-3, BC-4, BC-5, BC-7, BC-8, and BC-6/9 Grab

Sample Sites. 


\section{List of Figures}

FIGURE

Figure 2.3.1.

Passive Systems for AMD Treatment (Faulkner

11 and Skousen 1994).

Figure 3.1.1. Regional Map of the Beaver Creek Watershed.

Figure 3.1.2

Map of Beaver Creek Watershed and the Water

Quality Grab Sample Sites in Relation to the Appalachian Corridor-H Alignment.

Figure 3.1.3.

Mine Lands in the Beaver Creek Watershed in

Relation to the Water Quality ampling Sites.

Figure 3.2.1.1. Photograph of The Upper Beaver Creek Sampling Station 25 (Site BC-1).

Figure 3.2.2.1. Photograph of the Elder Swamp Sampling Station (BC-2). 26

Figure 3.2.3.1. $\quad$ Photograph of the Gatzmer Sampling Station (Site BC-3). 27

Figure 3.2.4.1. $\quad$ Photograph of the Iron Pond Sampling Station (BC-4). $\quad 28$

Figure 3.2.5.1. $\quad$ Photograph of the Slate Culvert Sampling Station (BC-5). 29

Figure 3.2.6.1. $\quad$ Photograph of the Chaffee Run Sampling Station 30

(Site BC-7).

Figure 3.2.7.1. $\quad$ Photograph of the Hawkins Run Sampling Station (BC-8). 31

Figure 3.2.8.2.1. $\quad$ Photograph of the Davis Sampling Station (Site BC-9). 33

Figure 3.6.1.1. $\quad$ QA/QC Comparison of Depth Recorded at 47

BC-3 by the YSI Sondes with the Depth Recorded

by the USGS Gauging Station at Davis, WV.

Figure 3.6.1.2. $\quad$ QA/QC Comparison of Depth at BC-9 by the

YSI Sondes with Depth Recorded from the USGS

Gauging Station at Davis, WV.

Figure 5.2.1.

pH Data Collected by the YSI Sondes from the BC-1.

85

Figure 5.3.1. Comparison of $\mathrm{pH}$ Data Collected at BC-1 and

92 BC-3 by the YSI Sondes. 
Figure 5.3.2.

Comparison of Specific Conductance Data

Collected by the YSI Sondes Between BC-1 and BC-3.

Figure 5.4.1.1. A Comparison of $\mathrm{pH}$ Data Collected by the YSI Sondes at BC-3 and BC-6/9.

Figure 5.4.1.2. Comparison of Specific Conductance Data 98 Collected by the YSI Sondes at BC-3 and BC-6/9. 


\subsection{INTRODUCTION}

\subsection{Problem Statement}

The Beaver Creek watershed has been adversely impacted by extensive mining conducted prior to the passing of the Surface Mining Control and Reclamation Act (SMCRA) in 1977. Large amounts of acid producing material were exposed throughout the Beaver Creek watershed prior to 1977 due to the lack of regulations governing the management of mine waste material. As a result, the water quality in the Beaver Creek watershed had become severely impaired with Acid Mine Drainage (AMD). Furthermore, the proposed construction of Appalachian Corridor $H$ through the Beaver Creek watershed has raised the issue of re-disturbing the mine wastes throughout the watershed. The "cuts" and "fills" inherent with any highway construction provide the potential for future additional AMD impact in a setting such as the Beaver Creek watershed. Therefore, this study will explore possible methods that could be used to remediate the waters of the Beaver Creek watershed. Additionally, the opportunity for the restoration of the headwaters of Beaver Creek to a natural fishery will be discussed.

\subsection{Objectives}

The objectives of this research were:

- Characterize the water in the main channel of Beaver Creek and several of its major tributaries using water quality grab samples, in-situ water quality monitoring devices, and macroinvertebrate and fish sampling.

- Identify the major sources of Acid Mine Drainage (AMD) throughout the Beaver Creek watershed. 
- Make recommendations for the remediation of AMD sources.

- Determine the feasibility of restoring the headwaters of Beaver Creek to a natural fishery. 


\subsection{BACKGROUND}

\subsection{Impacts of Acid Mine Drainage on Stream Water Quality}

\subsubsection{Water Chemistry}

Acid mine drainage is a problem encountered during and after coal mining operations in the Eastern US. Pyrite, or iron sulfide $\left(\mathrm{FeS}_{2}\right)$, is the major iron-sulfur impurity found in mining byproducts that is responsible for the generation of AMD. When pyrite comes in contact with water, a dilute sulfuric acid $\left(\mathrm{H}_{2} \mathrm{SO}_{4}\right)$ is formed. The stochiometric basis for AMD formation is presented in Equations 2.1.1.1 through 2.1.1.4.

$$
4 \mathrm{FeS}_{2}(\mathrm{~s})+14 \mathrm{O}_{2}+4 \mathrm{H}_{2} \mathrm{O} \Leftrightarrow 4 \mathrm{Fe}^{2+}+8 \mathrm{H}^{+}+8 \mathrm{SO}_{4}{ }^{2-}
$$

Next, the free ferrous ions, $\mathrm{Fe}^{2+}$, are oxidized to form ferric iron, $\mathrm{Fe}^{3+}$,

$$
4 \mathrm{Fe}^{2+}+4 \mathrm{H}^{+}+\mathrm{O}_{2} \Leftrightarrow 4 \mathrm{Fe}^{3+}+2 \mathrm{H}_{2} \mathrm{O}
$$

The third step of the chemical reactions occurs as the ferric iron combines with water molecules to form ferric oxide, $\mathrm{Fe}(\mathrm{OH})_{3(\mathrm{~s})}$, commonly referred to as "yellow boy".

$$
4 \mathrm{Fe}^{3+}+12 \mathrm{H}_{2} \mathrm{O} \Leftrightarrow 4 \mathrm{Fe}(\mathrm{OH})_{3}(\downarrow)+12 \mathrm{H}^{+}
$$

Yellow boy is the precipitate commonly seen coating rocks and covering stream beds in AMD impacted streams. As the precipitate coats rocks and covers streambeds it smothers benthic habitats, cements the substrate and contributes to embeddedness (EPA 1997). The end result is typically a "dead stream", from a biological point of view.

Another chemical reaction of importance in the series that produces acidic drainage is as follows:

$$
\mathrm{FeS}_{2}(\mathrm{~s})+14 \mathrm{Fe}^{3+}+8 \mathrm{H}_{2} \mathrm{O} \Leftrightarrow 15 \mathrm{Fe}^{2+}+2 \mathrm{SO}_{4}{ }^{2-}+16 \mathrm{H}^{+}
$$


Equation 2.1.1.4 represents the cyclic and self propagating part of the system of equations outlined above and will continue until either ferric iron or the source of pyrite is depleted. Note that in Equation 2.1.1.4, iron in the oxidizing agent, not oxygen.

The rate limiting reaction for the series of chemical equations outlined above is the oxygenation of ferrous iron, Equation 2.1.1.2. The reaction rate constant, $\mathrm{k}$, for Equation 2.1.1.2 is $1 \times 10^{-25}$ (1/atm-min) at $25^{\circ} \mathrm{C}$ at $\mathrm{pH}$ less than 5.5 , which is an extremely slow rate of reaction (Snoeynk and Jenkins 1980, Stumm and Morgan 1996). However; experimentally, it is known that pyrite is rapidly oxidized to ferric iron, $\mathrm{Fe}^{3+}$. The difference between the theoretical and actual rate of oxygenation of iron observed in mine waters can be explained by microbial action by the microorganisms Thiobacillus thiooxidans, Thiobacillus ferrooxidans, and Ferrobacillus ferrooxidans (Snoeyink and Jenkins 1980), and the presence of chemical catalysts, such as $\mathrm{Cu}^{2+}$ and $\mathrm{Co}^{2+}$ in trace quantities, and anions that form complexes with $\mathrm{Fe}^{3+}$ (e.g., $\mathrm{HPO}_{4}{ }^{2-}$ ) (Stumm and Morgan 1996).

Therefore, two pathways for ferric iron to interact exist: through the formation of ferric hydroxide and the further reaction with pyrite to produce additional ferrous iron. The result of this is strong acids, which react with minerals in the soil, and create waters with increased hardness and total dissolved solids (Snoeyink and Jenkins 1980, Faulkner and Skousen 1998).

\subsubsection{Macro-invertebrates and Fish Populations}

Distribution of stream macro-invertebrates is closely related to substrate characteristics. The addition of fine sediments to substrates composed of larger material 
can be detrimental to macro-invertebrate communities. Major faunal change follows when there is gross siltation sufficient to smother the streambed or fill gaps between large substrate particles (Chessman et al., 1987, Gray, 1996). The sedimentation and flocculation of metals associated with AMD effectively blankets or "smothers" the macro-invertebrate habitat of receiving streams. The increased amount of particulate matter on the streambed also inhibits the respiratory and feeding processes of many macro-invertebrates (Jooste et al., 1999).

In addition to the increased sediment that can be created by the precipitation of AMD metals in streams, the aqueous phase concentrations of the same metals in the streams can also be detrimental to fish and macro-invertebrate communities. Jenkins et al. (1995) reported that benthic macroinvertebrates and fish require a $\mathrm{pH}$ minimum of 6.5 in order to survive. Even short term reductions ( $\sim 8$ hours) in stream $\mathrm{pH}$ were found to decrease benthic densities of many sensitive insect larvae in stream communities (Kratz et al., 1994; Lange and Lambert, 1995). Also, total suspended solids concentration should not exceed $80 \mathrm{mg} / \mathrm{L}$. The iron concentration should be less than $1.5 \mathrm{mg} / \mathrm{L}$ and manganese concentration should not be greater than $1.0 \mathrm{mg} / \mathrm{L}$ in order for a stream to maintain and support healthy aquatic life.

The Index of Well Being (IWB) is used to represent fish assemblage quality more realistically than a single diversity or abundance measure (Barbour et al. 1999) and is given by equation 2.1.2.1. The IWB incorporates two abundance and two dversity measures in an approximately equal fashion in order to more realistically represent a fish assemblage (Barbour et al. 1999). 


$$
I W B=0.5 \ln N+0.5 \ln B+\overline{H_{N}}+\overline{H_{B}}
$$

where $\quad \mathrm{N}=$ Number of individuals caught per unit distance sampled

$\mathrm{B}=$ Biomass of individuals caught per unit distance

$\bar{H}=$ Shannon diversity index, given in Equation 2.1.2.2 (Magurran, 1988).

$$
\bar{H}=-\sum \frac{n_{i}}{N} \ln \left(\frac{n_{i}}{N}\right)
$$

where $\quad n_{\mathrm{i}}=$ Relative number or weight of the $\mathrm{i}^{\text {th }}$ species

$\mathrm{N}=$ Total number or weight of the sample

Through the Index of Biological Integrity (IBI), Karr et al. (1986) provided a consistent theoretical framework for analyzing fish assemblage data. The IBI is an aggregation of 12 biological metrics that are based on the fish assemblage's taxonomic and trophic composition and the abundance and condition of fish. Such multipleparameter indices are important for making objective evaluations of complex systems. The IBI was designed for small midwestern warm water streams but has been modified for use in many regions (e.g., eastern and western United States, Canada, France) and in different ecosystems (e.g., rivers, impoundments, lakes, and estuaries). The metrics attempt to quantify a biologist's best professional judgment (BPJ) of the quality of the fish assemblage. Each metric is scored against criteria based on expectations developed from appropriate regional reference sites. Metric values approximating, deviating slightly from, or deviating greatly from values occurring at the reference sites are scored as 5,3 , or 1 , respectively. The scores of the metrics are added or averaged to produce an IBI score for the site. IBI metric alternatives for different geographic regions have been derived from the original metrics described by Karr (1981) for Illinois streams. There 
currently is not a specific IBI for the State of West Virginia, though the West Virginia Division of Natural Resources is working to develop one.

The West Virginia Stream Condition Index (WVSCI) was developed by the West Virginia Department of Environmental Protection (WVDEP) and was patterned after the Rapid Bioassessment Protocols (RBPs) developed by Plafkin et al. (1989) for the U.S. Environmental Protection Agency (USEPA) (USEPA, 2000). The index includes six biological metrics representing elements of the structure and function of the macroinvertebrate assemblage. To obtain a WVSCI score, the biological condition, from the six metrics sampled in the test stream, is compared to a reference site, which is an aggregation of conditions in unimpaired streams in the region (USEPA, 2000). The ranges of WVSCI scores and the corresponding stream condition ranks are presented in Table 2.1.2.1.

Table 2.1.2.1. WVSCI ranges and corresponding stream ranks (USEPA, 2000).

\begin{tabular}{|c|c|}
\hline Range & Rank \\
\hline \hline$<78$ to 100 & Very Good \\
$<68$ to 78 & Good \\
$<45$ to 68 & Fair \\
$<22$ to 45 & Poor \\
0 to 22 & Very Poor \\
\hline
\end{tabular}

\subsection{Prevention of Acid Mine Drainage}

Most AMD prevention techniques have been evaluated for application to surface mining operations. Due to the similarity between the disturbances caused by surface mining and roadway construction, many of the same prediction and prevention techniques can be applied to prevent AMD generation resulting from roadway construction. 
Common preventive measures include acid-base accounting, application of selective handling and placement of acidic waste materials, and alkaline additions.

Caruccio et al. (1988) reported that AMD was affected by the flow path of groundwater or any other water which might infiltrate into spoils and the unique geochemistry. Meek (1991) examined the available prediction and prevention techniques and determined the effectiveness of each process at preventing AMD. Through the collection of core samples, an acid-base account can be determined. Meek recommended that the maximum spacing between core samples be $\sim 305$ meters (1000 ft). A "paste $\mathrm{pH}$ " test was conducted on each core sample. Paste $\mathrm{pH}$ is the measure of pyretic salts, which is similar to the amount of weathering to which each stratum has been subjected. Another method of acid production prediction examined by Meek was the total pyretic sulfur analysis, which was a measure of the amount of acid producing material present in the rock. Neutralization potential analysis, which entails the measurement of alkalinity or neutralizing material present, was a third prediction technique explored by Meek. Selective handling and placement were recommended to minimize the disturbance of acid producing material prior to mining or blasting. The placement of such material should be made where exposure to oxygen and water can be minimized (e.g., containment in a cap with a liner, and/or application of a porous pad). Alkaline addition to the overburden was a third method of acid mine drainage prevention reported by Meek. Such additives included limestone admixing, phosphate admixing, and quick lime addition. The additives were mixed with the acid producing backfill at calculated intervals and then capped. This method not only seals off the acidic waste from oxygen and water, but also enables a second line of defense should any water infiltrate into the cap. 
Acid base accounting (ABA) has been evaluated by many researchers for its accuracy in predicting the potential for acid mine drainage. Brady et al. (1994) accredited Sobek (1978) with creating the original version of the acid base account. Smith et al. (1976) were the first to research the concept of the acid base account and derive overburden potentials from soil samples. The ABA was based on Equation 2.2.1:

$$
\mathrm{FeS}_{2}(s)+2 \mathrm{CaCO}_{3}(s)+3.75 \mathrm{O}_{2}+1.5 \mathrm{H}_{2} \mathrm{O} \rightarrow \mathrm{Fe}(\mathrm{OH})_{3}(\Downarrow)+2 \mathrm{SO}_{4}^{2-}+2 \mathrm{Ca}^{2+}+2 \mathrm{CO}_{2}
$$

When iron disulfide is mixed with calcium carbonate, oxygen, and water, ferric hydroxide, sulfate, calcium, and carbon dioxide are created. The sulfate produced through this reaction is the main acid generator.

The basis for the ABA as defined by Ferguson and Morin (1991) was a combination of an acid generation test based on a sulfur assay (determination of the percent sulfur present multiplied by 31.25 ) and a neutralization generation test based on the digestion of the acid and a titration. Based on the aforementioned analyses, the net neutralization potential (NNP; neutralization potential minus the acid generation potential) can be determined. All values used in the $\mathrm{ABA}$ are expressed in tons of $\mathrm{CaCO}_{3}$ equivalents per 1000 tons of material to be remediated. Ferguson and Morin determined that an NNP less than 5 tons of $\mathrm{CaCO}_{3}$ per 1000 tons could be considered acid generating and that an NNP greater than 20 tons of $\mathrm{CaCO}_{3}$ per 1000 tons would not be considered an AMD generating term in this reaction. Materials with an NNP of 5 to 20 tons of $\mathrm{CaCO}_{3}$ per 1000 tons were considered to be "unknowns" which required further testing (typically leaching tests) to determine how the material would react to exposure to the atmosphere. 


\subsection{Mitigation and Remediation of Acid Mine Drainage}

When treating acid mine drainage or waters with high metal concentrations, two major categories of treatment are employed: active or passive treatment. Active treatment methods include any system that must be operated with human labor, any treatment facility that reroutes the impaired water through a series of mechanical treatments, or any chemical addition that is maintained year round. Passive treatment methods are those that are implemented and left to operate with minimal to no operator intervention. Through biological and chemical processes that occur within the passive treatment systems, the water is cleansed (Faulkner and Skousen 1994). Passive treatments are starting to replace the costlier active treatment processes due to the lower operating costs, ease of use, and less maintenance associated with passive treatment systems. Eger and Lapakko (1989) estimated that passive treatment systems for AMD were less than $1 / 2$ the capital costs and 1/20 the maintenance costs of conventional active plants (as cited in Cohen and Staub, 1992). The six most commonly employed passive treatment technologies for AMD treatment are presented in Figure 2.3.1. 


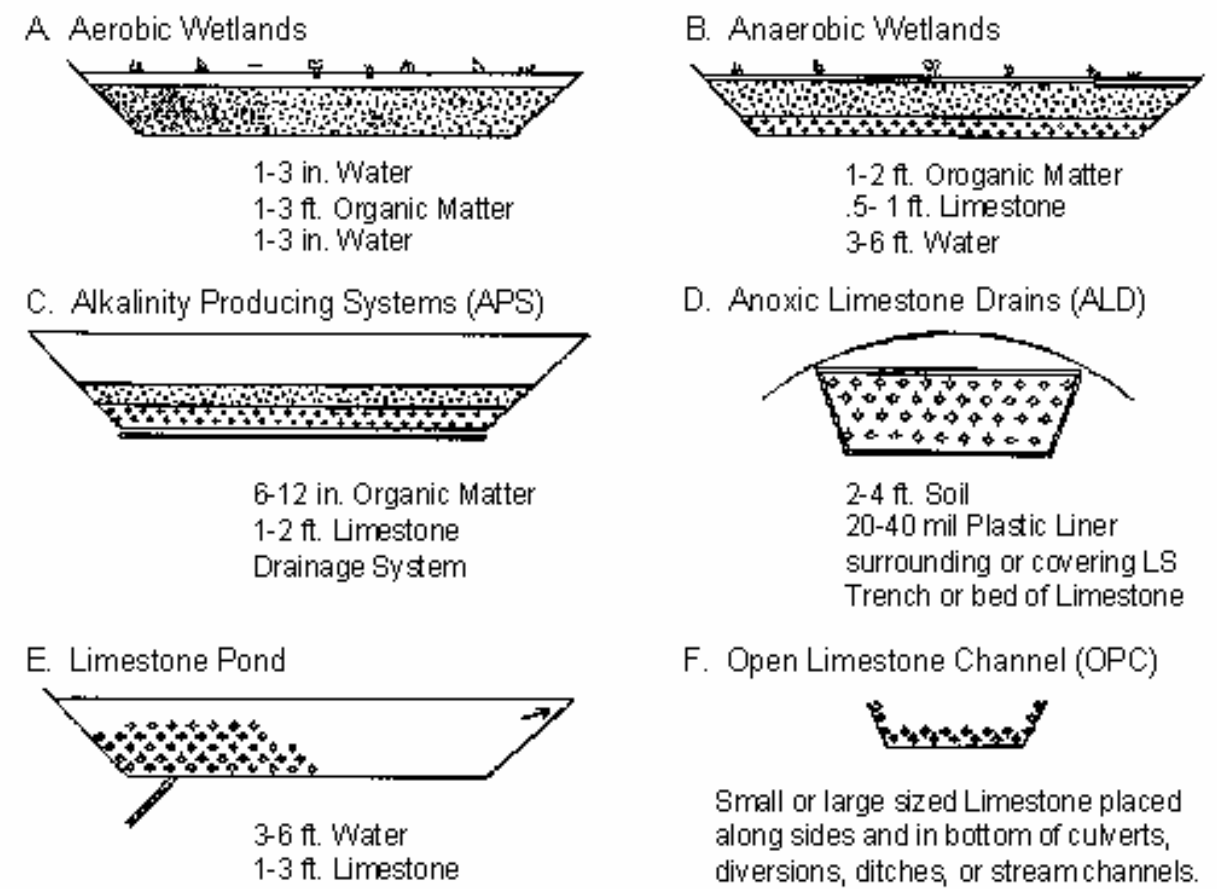

Figure 2.3.1. Passive Systems for AMD Treatment (Faulkner and Skousen
1994).

\subsubsection{Wetland Treatment Systems}

As early as the 1970s, natural wetlands have been used to treat acid mine drainage characterized by a low $\mathrm{pH}$ and high metal concentrations. AMD, however, degrades the quality of natural wetlands, which are protected by federal law. Thus, natural wetlands were replaced, as an AMD treatment system, with constructed wetlands. Constructed wetlands could be used to treat AMD because they are not governed by federal law (Faulkner and Skousen 1994).

Constructed wetlands utilize either anaerobic or aerobic vegetation. Metal uptake within the constructed wetland is performed by one of the following mechanisms: formation and precipitation of metal hydroxides; formation of insoluble metal sulfides; organic complexation reactions; and cation exchange of metals onto negatively charged 
soil sites. Other functional components of wetlands which aid in metal removal include: direct plant uptake; neutralization by carbonates; fastening to substrate soils; metal adsorption and exchange onto algae layers; and iron hydroxide formation and sulfate reduction through microbial dissimilation (Faulkner and Skousen 1994, Henrot and Wieder 1990, Wieder 1988, Wildeman et al. 1993).

Constructed aerobic wetlands are shallow pools over a relatively impermeable surface of soil, clay, or mine spoils which are typically vegetated with Typha spp, a plant with high metal uptake removal potential (Faulkner and Skousen 1994). Water collects in the wetland pool and is retained and aerated; upon oxidation, metals are precipitated. Aerobic wetlands have been found to decrease aluminum concentrations by $83 \%$, iron by $50 \%$ and manganese by $18 \%$. Aerobic wetlands can also increase $\mathrm{pH}$ and decrease the acidity by $43 \%$ (Faulkner and Skousen 1994).

Anaerobic wetlands are composed of vegetation, most commonly Typha spp, growing in deep, permeable sediments consisting of soil, peat, manure, other organic materials, and limestone. Treatment occurs through interactions within the organic carbon rich substrate. Metal oxidation in the anaerobic wetland takes place in the aerobic layers located at the surface of the wetland and through microbial reduction reactions, which also neutralize the $\mathrm{pH}$. The high Biological Oxygen Demand (BOD), produced by the organic carbon rich substrate, causes the water to become anaerobic as it passes through the wetland. The metal reducing mechanisms in the anaerobic wetland are similar to those in the aerobic wetland. Anaerobic wetlands have the potential to reduce iron concentrations $84 \%$, manganese concentrations $7 \%$, and the total suspended solids 63\% (Faulkner and Skousen 1994). 
Both anaerobic and aerobic wetlands have been known to create metalcontaminated soils and can potentially contaminate groundwater. The sorption of metals on the substrate eventually exhausts the removal capacities (Faulkner and Skousen 1994). Further, general factors that limit the success of wetland establishment include improper grade, improper wetland species, inadequate water level, erosion, and litter deposition and accumulation (Thrasher 1983).

The substrate of a constructed wetland, aerobic or anaerobic, should be designed to suit the character of water the wetland will treat. Vile and Wieder (1993) examined the alkalinity production of five substrates and determined whether the alkalinity was generated by ferric reduction or sulfate reduction. The five wetland substrates consisted of Sphagnum peat with a limestone and fertilizer mix, Sphagnum peat, sawdust, straw and manure, and mushroom compost. Water quality was tested at two temperatures, $4{ }^{\circ} \mathrm{C}$ and $25{ }^{\circ} \mathrm{C}$. No significant sulfate reduction was reported in any of the five substrates. Vile and Wieder found that the sawdust substrate exhibited a significant increase in ferrous iron concentration, which was four times greater at $25{ }^{\circ} \mathrm{C}$ than at $4{ }^{\circ} \mathrm{C}$ and that the alkalinity generation in the mushroom compost substrate was less than in the other four substrates.

In a constructed wetland experiment conducted by Sikora et al. (1996), an anaerobic wetland cell was followed by an aerobic wetland cell, in order to determine the influence of the combination on dissolved iron and manganese concentrations. The anaerobic wetland substrate was constructed of organic matter (i.e., mushroom compost, wood chips, and manure), limestone, and canary grass was used as the wetland vegetation. The aerobic wetland was composed of river gravel, through which the water 
would flow to be aerated after being oxygen-deprived from the high BOD of the anaerobic zone. A disadvantage to anaerobic treatment identified by Sikora et al. was the surface flow at the water-sediment interface which limited the amount of water being exposed to the reducing conditions within the anaerobic layers. An increase in alkalinity was reported at elevated temperatures in the anaerobic wetland. Sikora et al. found that the kinetic processes from which manganese $\left(\mathrm{Mn}^{2+}\right)$ was oxidized were slower than the oxidation of iron, decreasing the removal rate of manganese. Also, effective manganese oxidation requires a $\mathrm{pH}$ greater than 10 , which decreased the amount of manganese removed since the system $\mathrm{pH}$ was rarely increased above 6 . The presence of ferrous iron also hindered the reduction of manganese, as oxides are often utilized to remove iron instead of manganese. Wildeman et al. (1993) suggested that manganese removal in anaerobic wetlands would decline after the first two or three months. Sikora et al. (1996) reported similar results from their experiment, as manganese removal rates were $50 \%$ during the first three months, then the efficiencies declined to $10 \%$ as the wetland substrate became saturated with metals.

Brooks (1984) recommended several factors when designing a constructed wetland. Cattails provide erosion control and aid in the settling of sediments. Several characteristics typical to wetland construction to avoid are round sedimentation basins with uniform slopes and depths, which reduce flow. A supply of Typha spp and Sphagnum spp. is needed at the site prior to construction. Also, the utilization of more naturalized, meandering systems enhances plant establishment and sheet flow, therefore increasing the contact between water and substrate. Construction of obstacles helps minimize the channelization through a wetland. 
Stark et al. (1994) suggested that the substrate depth be approximately $15 \mathrm{~cm}$ of crushed limestone layered over $45 \mathrm{~cm}$ of spent mushroom compost or peat moss. By combining the limestone and the compost, an aerobic and anaerobic zone could be formed within the wetland. During ponding and slower flow rates, the water could infiltrate and be treated in both zones.

\subsubsection{Anoxic Limestone Drains}

Anoxic limestone drains (ALD) are a third method of passive AMD treatment. ALDs are buried trenches or ditches filled with limestone which channel water with high acidity and high dissolved metals content. Through the reactions with the limestone in the channel the $\mathrm{pH}$ is increased and the acidity is neutralized. The limestone filled ditches and/or trenches are typically buried, creating anoxic conditions in the buried channel (Turner and McCoy, 1990). In these channels, the limestone does not become coated or armored with iron hydroxide, as a result of increasing $\mathrm{pH}$, due to the lack of oxygen in the water. Upon exiting the ALD, the circumneutral $\mathrm{pH}$ and the aeration of the water promote the precipitation of metal hydroxides and the addition of alkalinity, in the form of bicarbonate, neutralizes the acidity by metal hydrolysis (Hedin and Nairn, 1993). ALDs are not intended to treat AMD on there own, rather they provide a means of generating the required alkalinity without the risk of biological limitations (Brodie et al., 1990). As a result, ALDs typically precede a constructed wetland, settling pond, or any other structure that will facilitate the precipitation and settling of metal hydroxides. ALDs have been known to fail or function poorly, especially when the $\mathrm{pH}$ is below five 
and when anoxic conditions are not maintained within the channel resulting in the armoring of the limestone in the channel (Faulkner and Skousen 1994).

In a study by Hedin and Watzlaf (1994), 21 pre-existing anoxic limestone drains were monitored and characterized to evaluate the performance of the systems. In this study, the variation in alkalinity generation was found to be less than the variation in acidity removal across all 21 study sites. The largest changes in acidity were found to be a result of the retention of ferric iron and aluminum by the ALDs. Ferrous iron was not significantly retained unless the retention times in the ALDs exceeded 650 hours and none of the ALDs retained any manganese or sulfate. Also, the concentration of alkalinity generated by the ALDs reached a maximum after 14-23 hours of retention time, with no marked increase in alkalinity after 23 hours.

\subsubsection{Open Limestone Channels}

Open limestone channels (OLCs) are open channels or ditches that are lined with coarse limestone aggregate. OLCs treat AMD by introducing alkalinity via the dissolution of calcium carbonate in the channel, thus increasing the $\mathrm{pH}$ and precipitating metal hydroxides (Ziemkiewicz et al., 1994). Factors such as length of channel and channel gradient, which affect turbulence and the buildup of coatings, are design factors that can be varied for optimal performance (Faulkner and Skousen, 1994). Faulkner and Skousen (1994) also recommend that a channel gradient of $20 \%$ be used for optimal performance of the OLC. The high gradient serves to scour iron and aluminum hydroxide coatings from the limestone and keep the metal precipitates suspended in solution. 
In the past, assumptions were made that the limestone in an OLC ceases to dissolve when the limestone becomes coated or armored with iron and aluminum hydroxides. Subsequent experiments showed that armored limestone continues to dissolve at approximately $20 \%$ of the rate of unarmored limestone (Pearson and McDonnell, 1975). Ziemkiewicz et al. (1994) recommended that OLCs be constructed on steep slopes and approximately five times longer to account for the armoring effect. In Ziemkiewicz et al. (1997), the armoring of limestone was found to reduce the dissolution of limestone between 2 and 50\%. Also, Ziemkiewicz et al. (1997) found that steeper OLCs performed better than channels located on flatter terrain due to the scouring effect that reduces the coating of the limestone.

\subsubsection{Sulfur-Reducing Bacteria}

Sulfur-reducing bacteria (SRB) have been added to active and passive treatment methods, with primary focus on wetland treatment systems. Research has been conducted to evaluate the SRB metal removal efficiency in wetlands, biotrenches, and in pit and mine shaft applications (Kuyucak and St-Germain 1995). Kuyucak and StGermain found that SRBs used in place of hydroxide precipitates had several advantages: high metal removals (e.g., copper, cadmium, zinc, lead, arsenic, mercury, nickel, and iron) at low $\mathrm{pH}$ ranges (3-6), a smaller volume and a more stable precipitate sludge. SRBs were less expensive than the standard sulfide reagents. Kuyucak and St-Germain examined the use of SRBs in situ and reported that the SRBs could be applied to open pits and mines and could easily be manipulated as a large, natural reactor. Nutrients were tested for their ability to aid the SRB activity. Those nutrients providing for the most 
SRB reactions included: cellulosic wastes (e.g., wood pulp, sawdust, bark, leaves, oat straw, and fuel and horticultural peat), organics (such as cattle manure, distillers' and brewers' dried grains, whey, molasses, and starch), and a lactic acid mixture. A stable substrate for a wetland supporting SRB activity was found to consist of limestone and either sand, phosphate, sulphidic rock, or woodchips. Kuyucak and St-Germain determined that sulfur-reducing bacteria were most efficient in low load situations $(\mathrm{pH}>$ 3.0 and low metal concentrations); however, the efficiency decreased with the decrease of $\mathrm{pH}$ and increase in metal concentrations.

\subsubsection{Limestone Sands}

The treatment of AMD impacted streams with sand-sized limestone particles is another form of passive AMD treatment (Faulkner and Skousen, 1994). The limestone sand is dumped into AMD impacted streams at various locations throughout an AMD impacted watershed. After being deposited in the stream, the water flow redistributes the sands downstream, neutralizing the acid as the stream moves the limestone downstream. Faulkner and Skousen also stated that the agitation and scouring of the limestone by the streamflow offset the armoring effect and kept fresh surfaces available for reaction.

The West Virginia Department of Environmental Protection treats many AMD impacted rivers and streams in West Virginia using limestone sands. In a study by Zurbuch (1996), 41 sites in the Middle Fork River, including 27 tributaries, were monitored. The dose of limestone sand which was added to a stream was based on the average annual acid load. The average annual acid load of a stream can be determined by multiplying the average annual acidity $\left(\right.$ as $\mathrm{CaCO}_{3}$ ) by the average annual flow. For non- 
AMD impacted streams the recommended dose of limestone sand is four times the average annual acid load. Likewise, for AMD impacted tributaries the recommended limestone sand dose was two times the average annual acid load.

After the first year of treatment the dose was decreased to an amount equal to the annual acid load of the stream. The $\mathrm{pH}$ of the water was maintained above 6.0 for several miles downstream of treatment sites and the anticipated limestone coating was not observed at those sites.

\subsection{Social and Economic Benefits}

Historically, many Appalachian communities have been confronted with the adverse affects of AMD. As public concern for environmental integrity has increased, calls for the remediation of AMD sites have become more prevalent on the political agendas of regional stakeholders. As a result, the social and economical benefits associated with the remediation of AMD sites have been widely analyzed by policy makers.

Decisions about the desirability of any AMD remediation plan or project includes a trade-off between the initial capital investment in equipment and facilities and a series of short-term benefits and longer term welfare gains. Some of the benefits that are derived from consumers using the system, or "use benefits", may include making the water potable and suitable for industrial use, recreational activities, or any other use

which incurs a capital return. Another benefit included with the "use benefits" was the educational value of the system and the associated historical industrial locations associated with the reclaimed mine location. The "non-use and option benefits" or 
benefits that may not produce a capital return include the improved environmental conditions and aesthetic value of the land. This also tends to precipitate civic pride and a sense of well being among the community (Button et al., 1999).

\subsection{In-Situ Water Quality Monitoring}

No relevant articles could be found detailing the use of in-situ water quality monitoring devices such as YSI Sondes, which were used in this study. 


\subsection{EXPERIMENTAL APPROACH}

\subsection{DESCRIPTION OF STUDY SITE}

The Beaver Creek watershed is located in the northeast section of Tucker County, West Virginia. Beaver Creek begins near the Tucker-Grant County line on US Route 93 and drains southeast toward Davis, West Virginia where it discharges into the Blackwater River. The majority of the land cover in the Beaver Creek watershed is forest with a few areas of scrub-shrub and wetland. The Beaver Creek watershed was heavily surfacemined from the 1920's to the 1980's leaving large areas of mining waste material throughout the watershed. A regional map illustrating the location of the Beaver Creek watershed is presented in Figure 3.1.1.

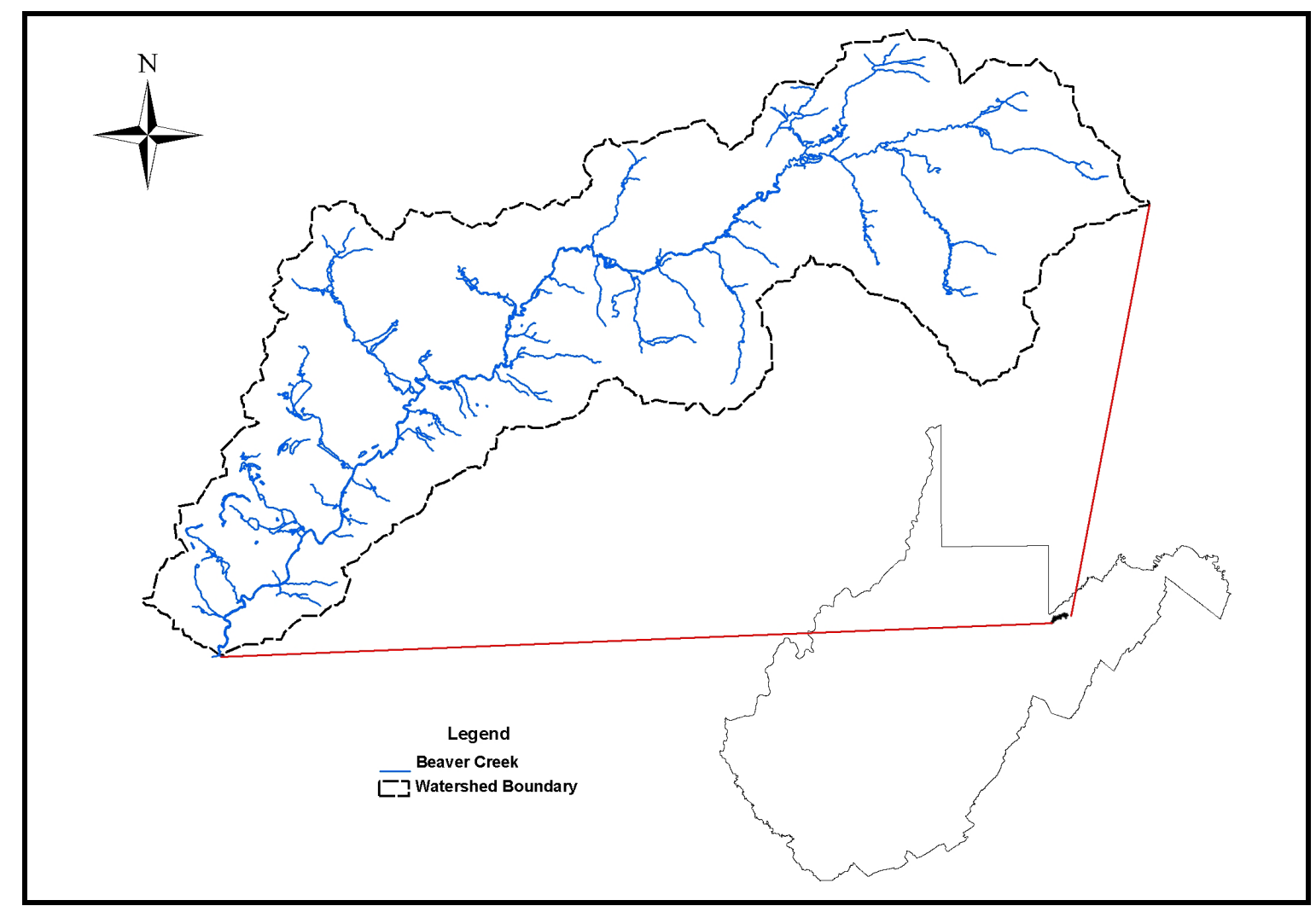

Figure 3.1.1. Regional Map of the Beaver Creek Watershed. 
In an attempt to establish the water quality in the Beaver Creek watershed, nine water quality sampling sites were designated along Beaver Creek. The water quality sampling sites were chosen at points of interest both along the main channel of Beaver Creek and in its tributaries for the purpose of establishing baseline water quality conditions as well as identifying major inputs of impaired waters. The locations of sampling sites are presented in Figure 3.1.2.

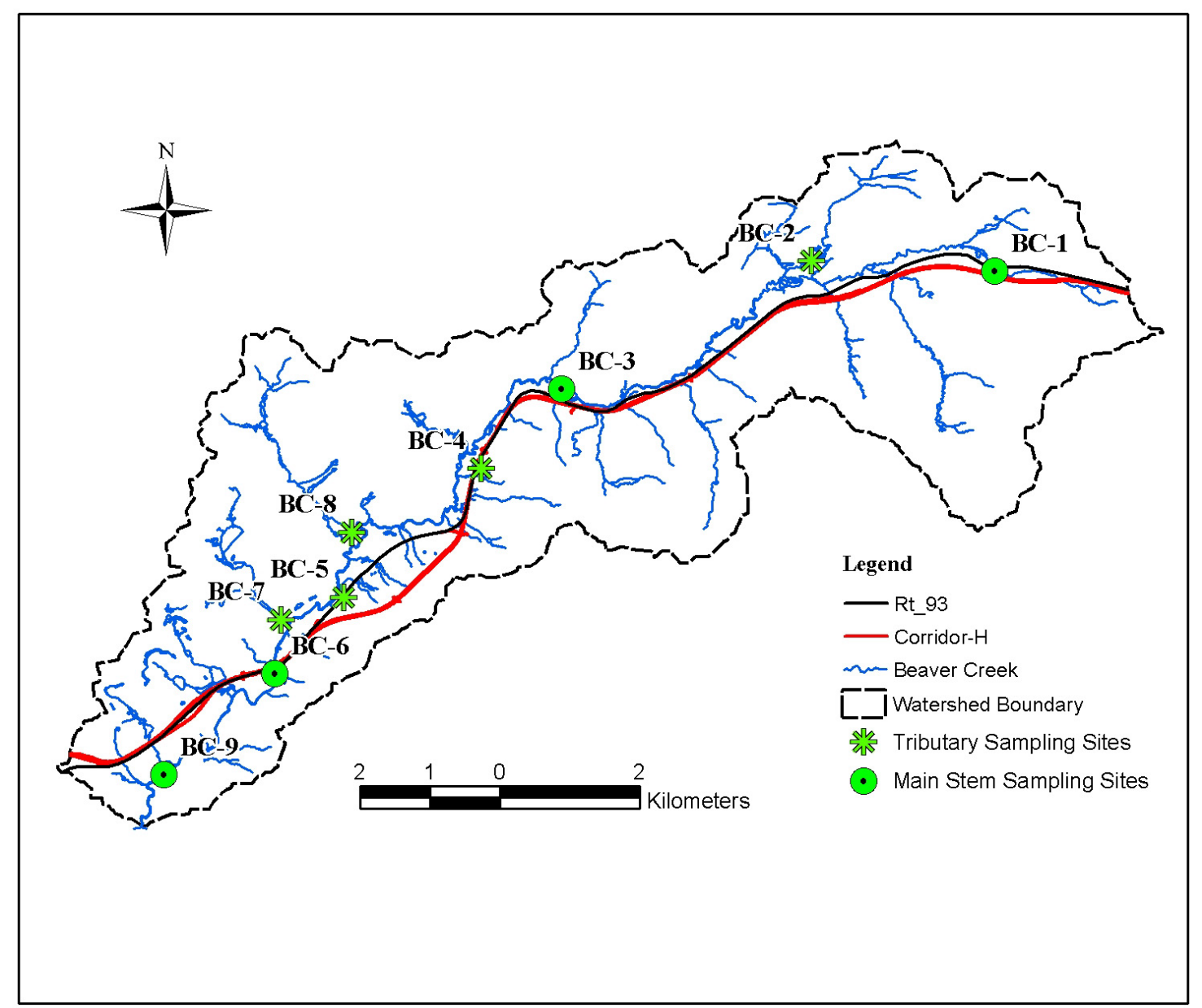

Figure 3.1.2 Map of Beaver Creek Watershed and the Water Quality Grab Sample Sites in Relation to the Appalachian Corridor-H Alignment.

Therefore, sample sites were designated at the headwaters of Beaver Creek, on tributaries of interest along Beaver Creek, and at the confluence of Beaver Creek and the Blackwater River, at the mouth of the watershed. This arrangement of sample sites 
helped WVU-CEE researchers to locate tributaries that were contributing to the degradation of environmental conditions in Beaver Creek and determine the degree to which these contributions affected the main channel of Beaver Creek.

The sampling sites chosen in the main channel of Beaver Creek were Upper Beaver Creek (BC-1), at the headwaters of the Beaver Creek watershed, Elder Swamp (BC-2), downstream of Upper Beaver Creek, Gatzmer (BC-3), the approximate mid-point of the watershed, Lower Beaver Creek (BC-6), near the outlet of the watershed, and Davis (BC-9), near the outlet of the watershed. The sampling sites chosen in tributaries of Beaver Creek were Iron Pond (BC-4), a tributary that enters Beaver Creek from the south, Slate Culvert (BC-5), a tributary that enters Beaver Creek from the south, Hawkins (BC-7), a tributary that enters Beaver Creek from the north, and Chaffee (BC-8), a tributary that enters Beaver Creek from the north. The mined land in the Beaver Creek watershed with respect to the water quality monitoring sites is presented in Figure 3.1.3. 


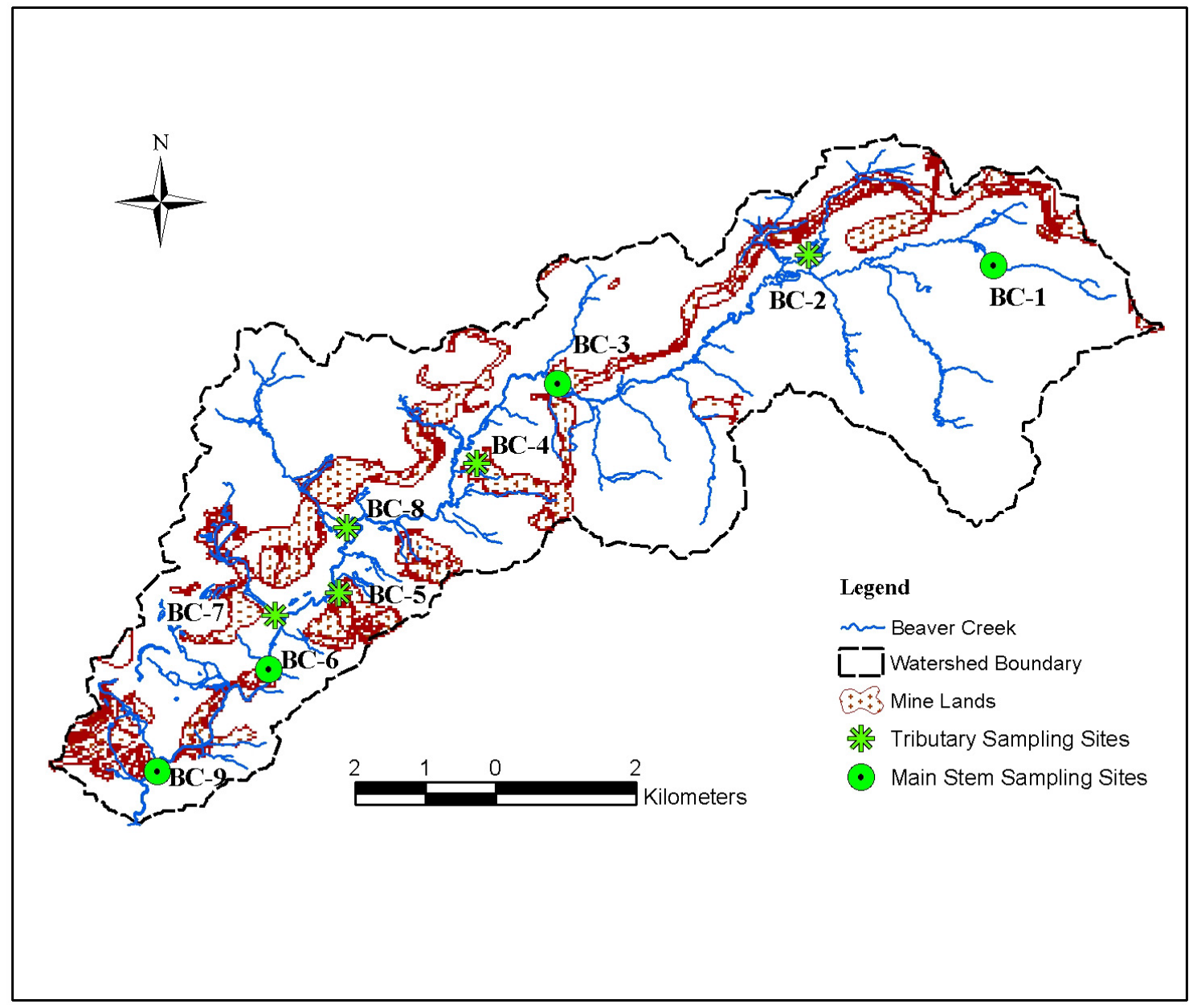

Figure 3.1.3. Mine Lands in the Beaver Creek Watershed in Relation to the Water Quality ampling Sites.

\subsection{DESCRIPTION OF SAMPLING SITES}

Six of the nine aforementioned sampling sites in Section 3.1 were designated as deployment sites for the WVU-CEE continuous monitoring devices, also known as "YSI Sondes". The sampling sites chosen for YSI Sonde deployment were: Upper Beaver Creek, Gatzmer, Hawkins, Chaffee, Lower Beaver Creek, and Davis. These sites were chosen as YSI Sonde deployment sites because, together, the sites were representative of the overview water quality conditions in the Beaver Creek watershed. The aforementioned deployment sites are further described in the following sub-sections. 


\subsubsection{Upper Beaver Creek}

Located at the head of the Beaver Creek watershed, Upper Beaver Creek, site BC1, was the first site chosen for the water quality analysis of Beaver Creek with the YSI Sondes. A photograph of Upper Beaver Creek is presented in Figure 3.2.1.1, where flow is moving from top to bottom.

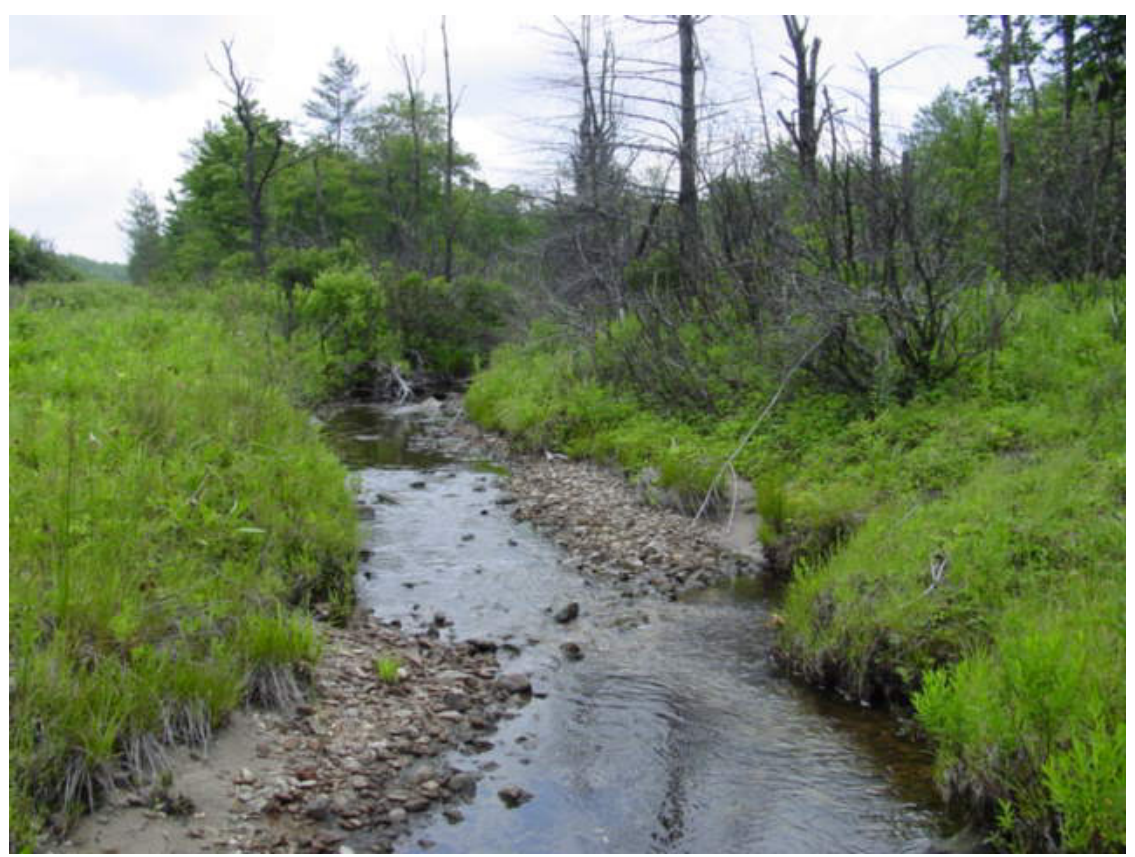

Figure 3.2.1.1. Photograph of The Upper Beaver Creek Sampling Station (Site BC-1).

Site BC-1 represented the headwaters of Beaver Creek and provided WVU-CEE researchers with water quality conditions from waters that were historically and presently minimally impacted by mining activities in the Beaver Creek watershed.

\subsubsection{Elder Swamp}


The Elder Swamp sampling station (BC-2) was located downstream of the Upper Beaver Creek sampling site at the confluence of Beaver Creek and a tributary. The tributary that converged with the main channel of Beaver Creek in Elder Swamp conveyed treated AMD water. A photograph of Elder Swamp taken from BC-2 sampling station is presented in Figure 3.2.2.1.

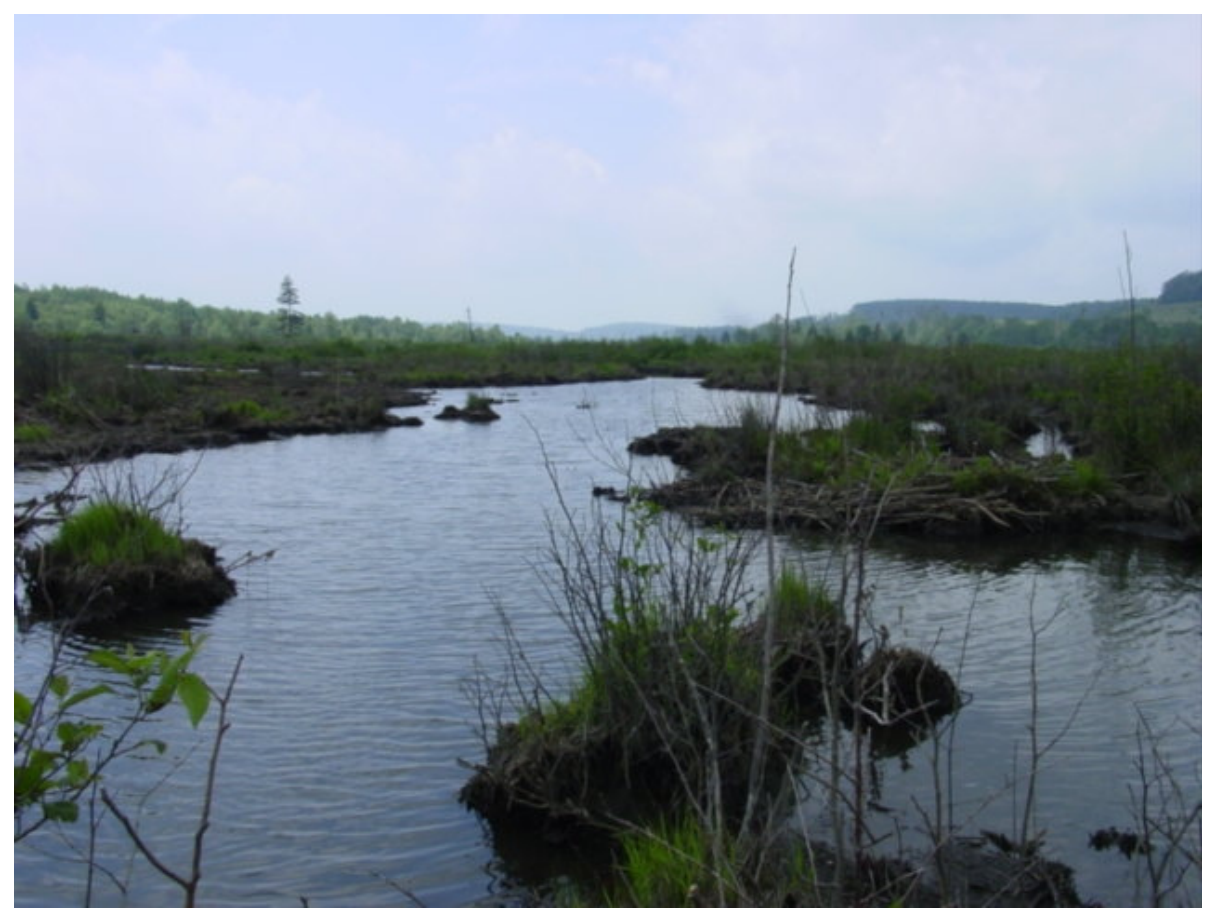

Figure 3.2.2.1. Photograph of the Elder Swamp Sampling Station (BC-2).

The BC-2 sampling site represented the first input of AMD impacted water into the main channel of Beaver Creek. BC-2 was not chosen as a YSI Sonde deployment site, but was monitored as part of the water quality grab sampling regime.

\subsubsection{Gatzmer}

The Gatzmer sampling site (BC-3) was located roughly midway down the Beaver Creek watershed, just down stream of the bridge that crosses Beaver Creek on the Buffalo 
Coal access road. A photograph of the Gatzmer sampling site is provided in Figure 3.2.3.1, where flow is from bottom to top.

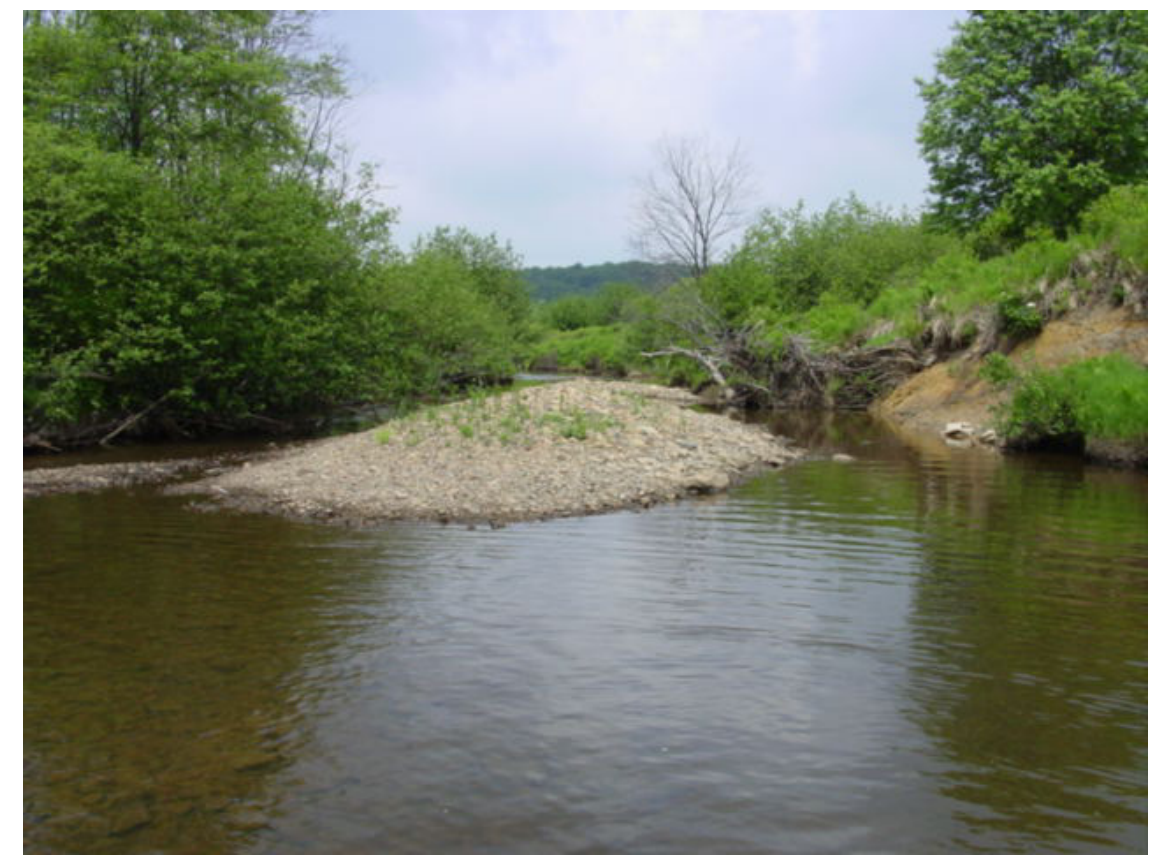

Figure 3.2.3.1. Photograph of the Gatzmer Sampling Station (Site BC-3).

BC-3 was the second site designated as a deployment site for the YSI Sondes. BC-3 was chosen to represent the water quality in Beaver Creek above major suspected inputs of impaired water.

\subsubsection{Iron Pond}

The Iron Pond sampling station (BC-4) was located on a tributary that flowed into Beaver Creek downstream from BC-3 and was the first major input of AMD impaired water from the south side of Beaver Creek. A photograph of the BC-4 sampling site is presented in Figure 3.2.4.1. 


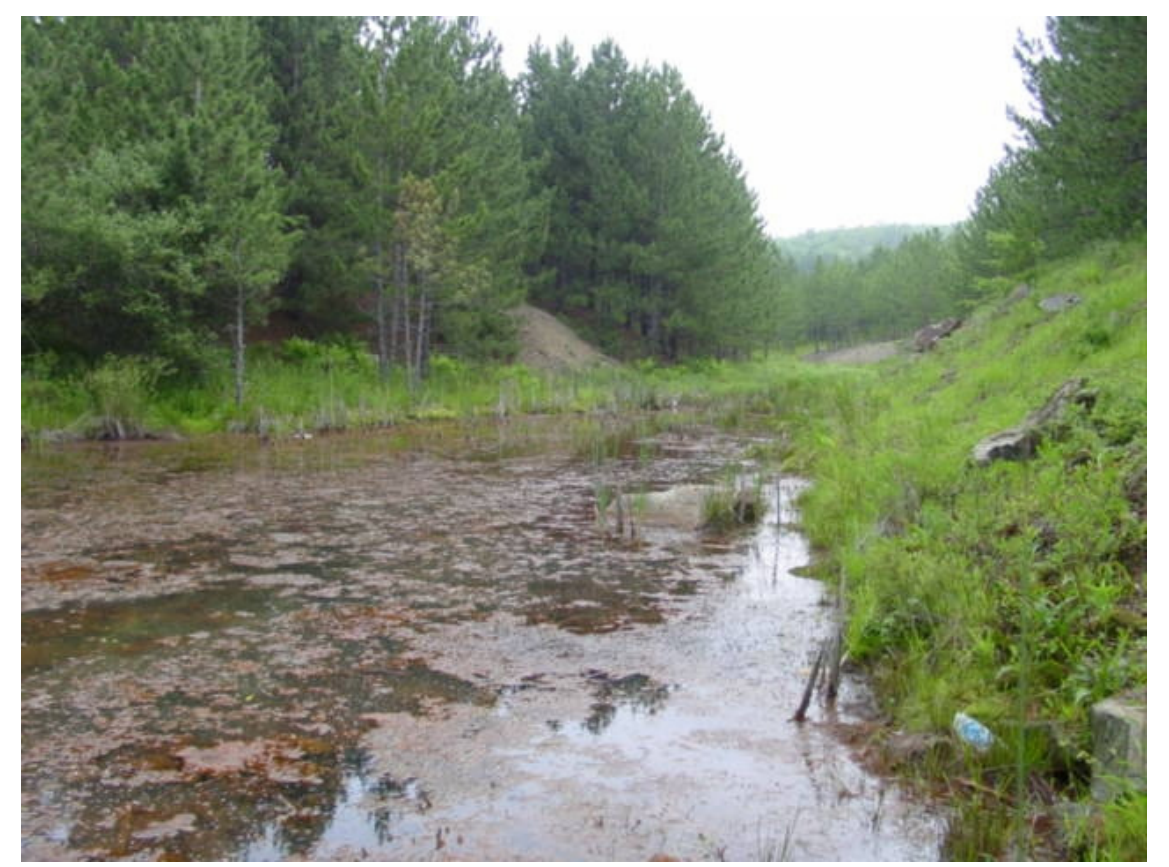

Figure 3.2.4.1. Photograph of the Iron Pond Sampling Station (BC-4).

The BC-4 sampling station was not chosen as a YSI Sonde deployment site but was monitored as part of the water quality grab sampling regime.

\subsubsection{Slate Culvert}

The Slate Culvert sampling station (BC-5) was located on a tributary that flowed into Beaver Creek between BC-7 and BC-8. A photograph of BC-5 is presented in Figure3.2.5.1. 


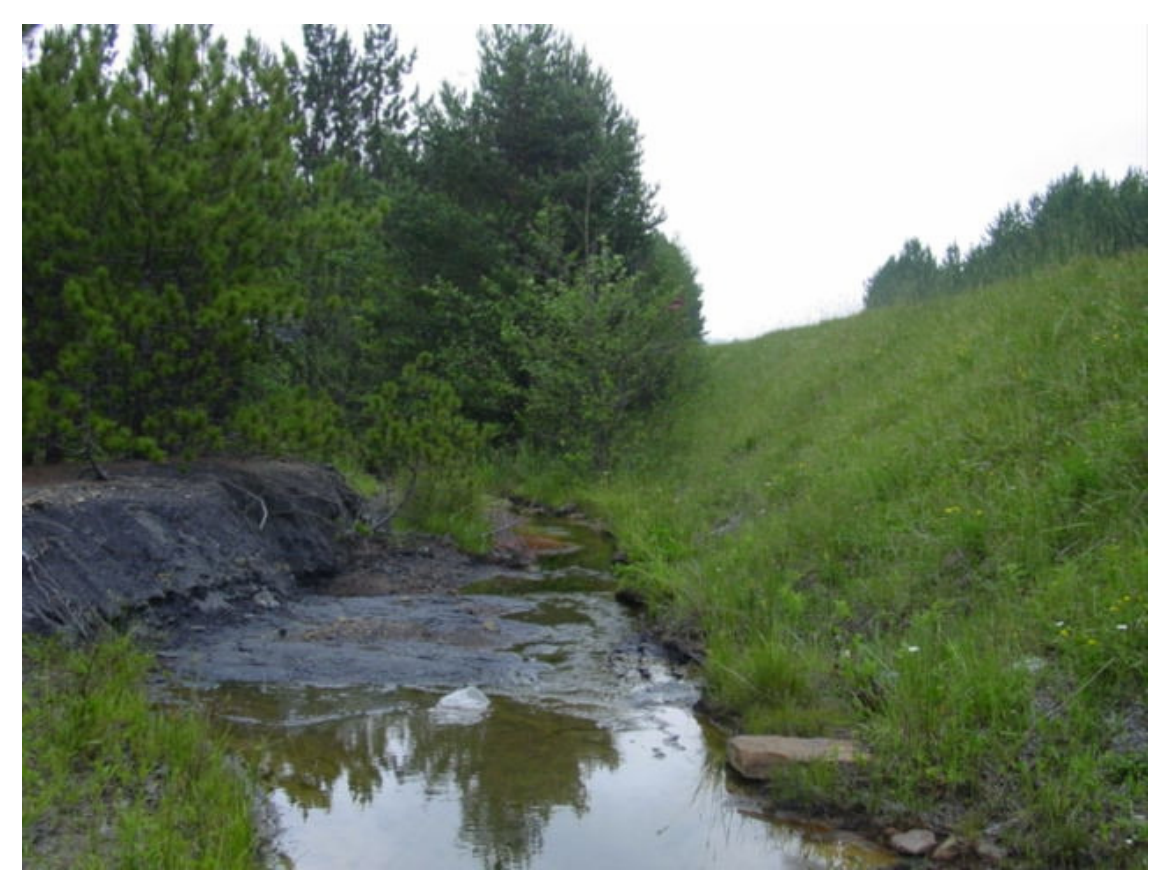

Figure 3.2.5.1. Photograph of the Slate Culvert Sampling Station (BC-5).

The BC-5 sampling station was the second major input of AMD impaired waters to enter Beaver Creek from the South. BC-5 was not selected as a YSI Sonde deployment site, but was monitored as part of the water quality grab sampling regime.

\subsubsection{Chaffee Run}

The Chaffee Run sampling site (BC-7) is located at the overflow of a beaver impoundment on a tributary of Beaver Creek, down stream of BC-3 and BC-8, and was the third YSI Sonde deployment site. A photograph of $\mathrm{BC}-7$ is provided in Figure 3.2.6.1, where flow is from top to bottom. 


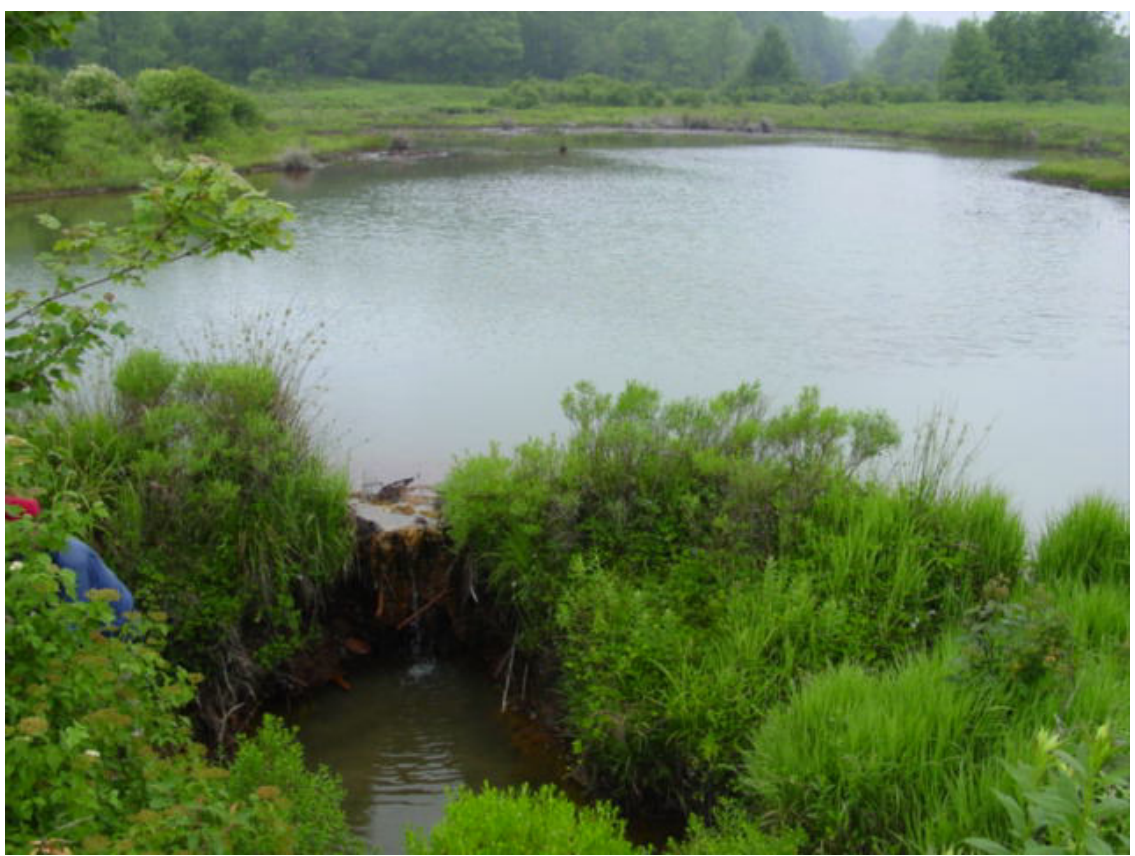

Figure 3.2.6.1. Photograph of the Chaffee Run Sampling Station (Site BC-7).

The tributary in which BC-7 is located conveys water from a sub-basin that has been impacted by mining activities in the past and is presently occupied by mine waste. The water quality data collected from BC-7 represents a suspected major source of impaired water entering Beaver Creek.

\subsubsection{Hawkins Run}

The Hawkins Run sampling site (BC-8) is located at the overflow of a beaver impoundment on a tributary of Beaver Creek, down stream of BC-3 and was the fourth YSI Sonde deployment site. A photograph of BC-8 is provided in Figure 3.2.7.1, where flow is from bottom to top. 


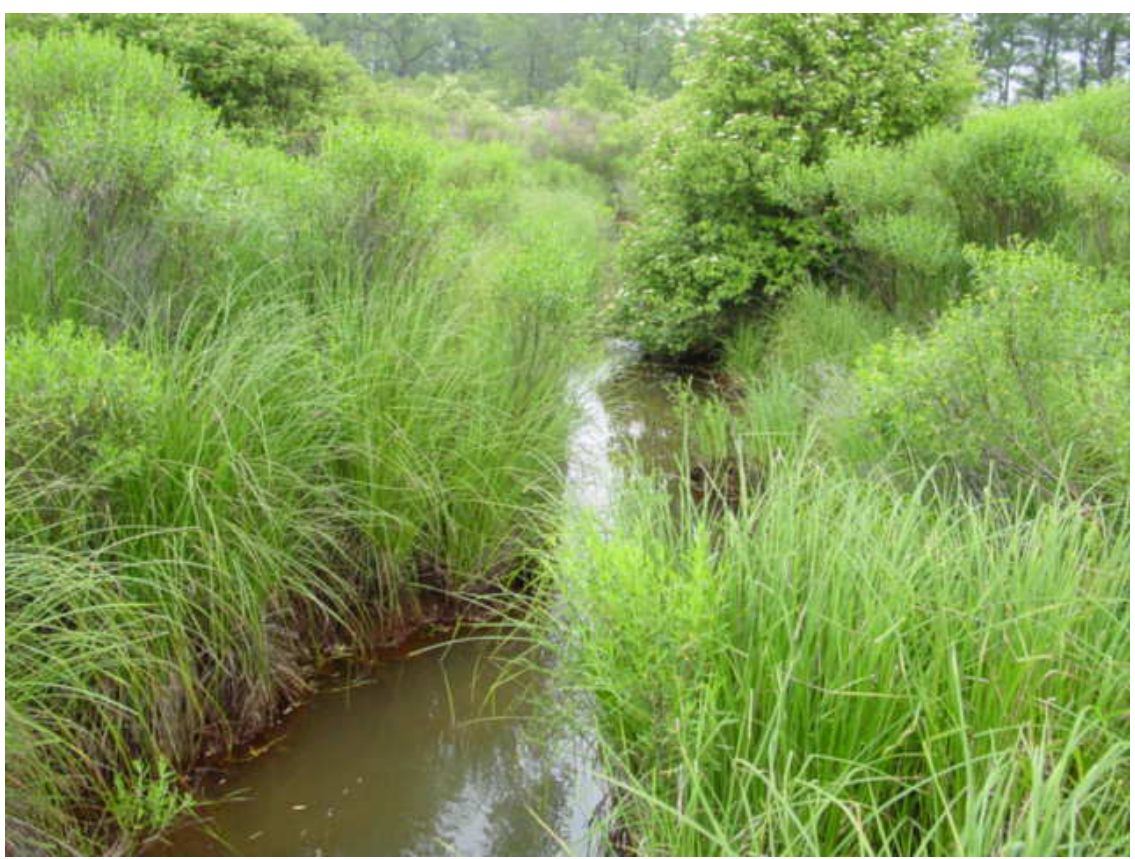

Figure 3.2.7.1. Photograph of the Hawkins Run Sampling Station (BC-8).

The tributary in which BC-8 is located conveys water from a sub-basin that has been impacted by mining activities in the past and is presently occupied by mine waste. The water quality data collected from BC-8 represents a suspected major source of impaired water entering Beaver Creek.

\subsubsection{Lower Beaver Creek Watershed Sampling Sites}

The first Beaver Creek watershed sampling site located near the bottom of the watershed was the Lower Beaver Creek sampling site. The Lower Beaver Creek sampling site was compromised when WVU-CEE researchers learned that a section of Appalachian Corridor- $H$ was to be constructed directly over the sampling site. The WVU-CEE researchers replaced the Lower Beaver Creek sampling site with the Davis sampling site, which was located downstream of the Lower Beaver Creek sampling site. 
In this section the Lower Beaver Creek and Davis sampling sites will be analyzed as a single sampling site throughout this study.

\subsubsection{Lower Beaver Creek}

The Lower Beaver Creek sampling site (BC-6) is located in the tailwaters of the Beaver Creek watershed, on Beaver Creek, underneath a bridge outside of Davis, WV on US Route 93. BC-6 was the fifth YSI sonde deployment site selected by the WVU-CEE researchers. BC-6 was selected as a study site by WVU-CEE researchers for the purpose of determining the water quality of Beaver Creek before it flowed into the Blackwater River.

\subsubsection{Davis}

The Davis sampling site (BC-9) is located just upstream of the outlet of the Beaver Creek watershed. A photograph of the Davis sampling site is presented in Figure 3.2.8.2.1. 


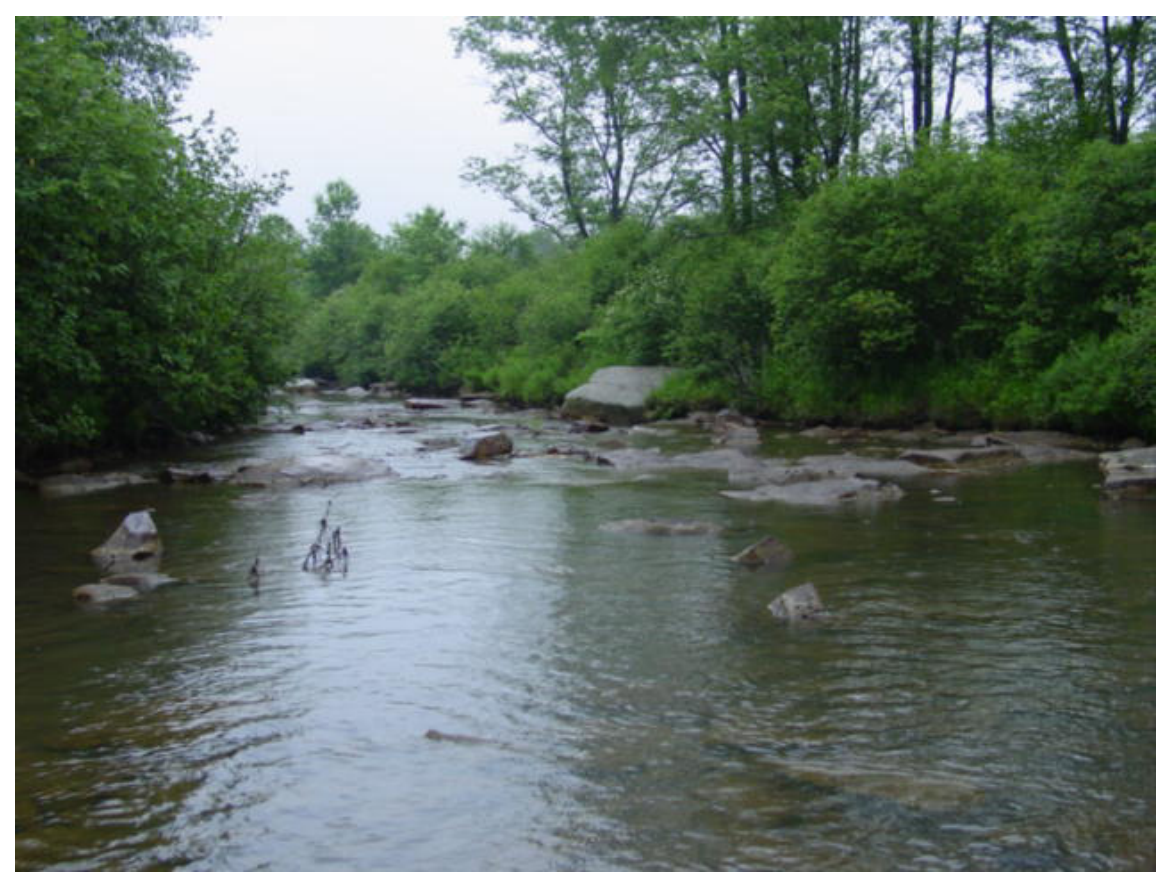

Figure 3.2.8.2.1. Photograph of the Davis Sampling Station (Site BC-9).

BC-9 was the sixth and last YSI sonde deployment site. BC-9 was selected to be a YSI sonde deployment site for the purpose of determining the water quality in Beaver Creek prior to its confluence with the Blackwater River.

\subsection{MATERIALS}

The device used to collect continuous data at the sampling sites described previously in Section 3.2 was an in-situ water quality monitoring device manufactured by Yellow Springs Instruments Co. (YSI), known as an "Environmental Monitoring Systems 6-Series Sonde". The YSI sondes were multi-parameter instruments capable of being deployed in a body of water, and reading/storing water quality data without intervention from researchers. The YSI sondes were capable of being configured to collect data on such water quality parameters as dissolved oxygen (DO) in percent and $\mathrm{mg} / \mathrm{L}$, conductivity, specific conductance, salinity, total dissolved solids, resistivity, 
temperature, $\mathrm{pH}$, oxidation reduction potential (ORP), depth, level, flow rate, turbidity, nitrate-N, ammonia-N, ammonium-N, chloride, and chlorophyll (YSI, 1999).

The YSI sondes were cylindrical in shape with a data-port for downloading saved water quality data on one end and the selected configuration of probes at the other end. A clear, airtight polyurethane casing, which was screwed onto the end of the sonde that housed the probes, covered and protected the probes during downtime and transport. During the time that the sondes were deployed in a body of water, the polyurethane casing was replaced with a plastic casing with holes which allowed water to flow through and contact the probes. Attached to the data port of the sonde, during deployment, was an 8 meter long data transfer cord that could be used to download water quality data without disturbing the sonde. Also, attached to that cord was a barometric pressure sensor that was used in the determination of water depth by measuring the difference in ambient air pressure and the pressure exerted by the water above the sonde. During downtime and transport, the cord was removed from the data port and replaced by an airtight cap. The YSI Sondes were capable of recording water quality data on an hourly basis for up to 90 days, needing only periodic in-situ cleaning and calibration to keep the probes in working order.

The YSI Environmental Monitoring System used by the WVU-CEE researchers in the Beaver Creek watershed was the 6920 model sonde with a probe configuration to measure turbidity, dissolved oxygen (percent and $\mathrm{mg} / \mathrm{L}$ ), temperature, $\mathrm{pH}$, specific conductance, and depth. The ranges and accuracy of the probes that the WVU-CEE researchers selected for the YSI sondes in the Beaver Creek watershed are presented in Table 3.3.1 (YSI, 1999). 
Table 3.3.1. Range and Accuracy of YSI Sonde Probes Employed in the Beaver Creek Watershed (YSI, 1999).

\begin{tabular}{|c|c|c|}
\hline Probe & Range & Accuracy \\
\hline Temperature & -5 to $45^{\circ} \mathrm{C}$ & $+/-0.15^{\circ} \mathrm{C}$ \\
\hline $\begin{array}{c}\text { Dissolved Oxygen, } \% \\
\text { Saturation }\end{array}$ & $\begin{array}{c}0 \text { to } 500 \% \text { air } \\
\text { saturation }\end{array}$ & $\begin{array}{c}+/-2 \% \text { of } \\
\text { reading }\end{array}$ \\
\hline Dissolved Oxygen, $\mathrm{mg} / \mathrm{L}$ & 0 to $50 \mathrm{mg} / \mathrm{L}$ & $\begin{array}{c}+/-2 \% \text { of } \\
\text { reading }\end{array}$ \\
\hline pH & 0 to 14 standard units & $+/-0.2$ units \\
\hline Turbidity & 0 to $1000 \mathrm{NTU}$ & $\begin{array}{c}+/-5 \% \text { of } \\
\text { reading }\end{array}$ \\
\hline Specific Conductance & 0 to $100 \mathrm{mS} / \mathrm{cm}$ & $\begin{array}{c}+/-5 \% \text { of } \\
\text { reading }\end{array}$ \\
\hline Depth & 0 to $9.1 \mathrm{~m}$ & $+/-0.003 \mathrm{~m}$ \\
\hline
\end{tabular}

\subsection{SAMPLING REGIME}

\subsubsection{YSI Sondes}

After the five sonde deployment sites were designated in the Beaver Creek watershed the YSI sondes were then deployed for thirty days at a time. When the thirtyday deployment period had expired, the sondes were retrieved, transported back to the lab for downloading of data, and redeployed by WVU-CEE researchers. The deployment

periods for each Beaver Creek watershed YSI sonde deployment site are presented in Table 3.4.1.1. 
Table3.4.1.1. YSI Sonde Deployment and Retrieval Dates for Beaver Creek.

\begin{tabular}{|l|l|l|l|l|l|l|l|l|l|l|l|l|l|}
\hline \multicolumn{1}{c|}{} & \multicolumn{7}{c|}{ Deployment and Retrieval Dates for Beaver Creek } \\
\hline & $2 / 14 / 01$ & $3 / 20 / 01$ & $4 / 13 / 02$ & $5 / 17 / 01$ & $6 / 28 / 01$ & $8 / 2 / 01$ & $9 / 12 / 01$ & $10 / 16 / 01$ & $12 / 19 / 01$ & $2 / 2 / 02$ & $4 / 23 / 02$ \\
\hline Site ID & $3 / 14 / 01$ & $4 / 12 / 01$ & $5 / 13 / 01$ & $6 / 17 / 01$ & $7 / 26 / 01$ & $9 / 1 / 01$ & $10 / 15 / 01$ & $11 / 15 / 01$ & $1 / 19 / 02$ & $4 / 5 / 02$ & $7 / 13 / 02$ \\
\hline BC-1 & & & & & & & & & & & \\
\hline BC-2 & & & & & & & & & & & \\
\hline BC-3 & & & & & & & & & & & \\
\hline BC-4 & & & & & & & & & & & \\
\hline BC-4B & & & & & & & & & & & \\
\hline BC-5 & & & & & & & & & & & \\
\hline BC-6 & & & & & & & & & & & \\
\hline BC-7 & & & & & & & & & & & \\
\hline BC-8 & & & & & & & & & & & \\
\hline BC-9 & & & & & & & & & & & \\
\hline BC-10 & & & & & & & & & & & \\
\hline BC-11 & & & & & & & & & & & \\
\hline BC-12 & & & & & & & & & & & \\
\hline BC-13 & & & & & & & & & & & \\
\hline
\end{tabular}

From February 14, 2001 to January 19, 2002 the YSI Sondes were deployed for a period of thirty days with the sondes being cleaned and calibrated in the WVU-CEE lab between deployments. After January 19, 2002, WVU-CEE researchers began deploying the YSI Sondes for periods between sixty and ninety days. During these longer deployment periods the WVU-CEE researchers preformed in-situ cleaning and calibration to keep the YSI Sondes working properly. The in-situ cleaning and calibration of the YSI Sondes was conducted roughly every thirty days during the longer deployment periods.

\subsubsection{Grab Samples}

On March 28, 2000, WVU-CEE researchers made the first reconnaissance trip to the Beaver Creek watershed in order to select preliminary water quality grab sample sites and retrieved water quality grab samples from $\mathrm{BC}-1, \mathrm{BC}-3$, and $\mathrm{BC}-6$. The subsequent 
Beaver Creek watershed water quality grab sample sites and sampling dates are presented in Table 3.4.2.1

Table 3.4.2.1. Beaver Creek Watershed Sampling Sites and Dates on Which the Sites Were Sampled.

\begin{tabular}{|l|l|l|l|l|l|l|l|l|l|l|l|l|l|l|l|}
\hline & \multicolumn{8}{c|}{ Grab Sampling Dates for Beaver Creek } \\
\hline & \multicolumn{8}{c|}{2000} & & \multicolumn{7}{c|}{2001} & \multicolumn{2}{c|}{2002} \\
\hline Site ID & $3 / 28$ & $9 / 16$ & $10 / 29$ & $12 / 10$ & $1 / 24$ & $4 / 27$ & $6 / 21$ & $8 / 6$ & $9 / 22$ & $10 / 3$ & $12 / 19$ & $1 / 19$ & $2 / 24$ & $4 / 5$ \\
\hline BC-1 & & & & & & & & & & & & & & \\
\hline BC-2 & & & & & & & & & & & & & & \\
\hline BC-3 & & & & & & & & & & & & & & \\
\hline BC-4 & & & & & & & & & & & & & & \\
\hline BC-4B & & & & & & & & & & & & & & \\
\hline BC-5 & & & & & & & & & & & & & & \\
\hline BC-6 & & & & & & & & & & & & & & \\
\hline BC-7 & & & & & & & & & & & & & & \\
\hline BC-8 & & & & & & & & & & & & & & \\
\hline BC-9 & & & & & & & & & & & & & & \\
\hline BC-10 & & & & & & & & & & & & & & \\
\hline BC-11 & & & & & & & & & & & & & & \\
\hline BC-12 & & & & & & & & & & & & & & \\
\hline BC-13 & & & & & & & & & & & & & \\
\hline
\end{tabular}

On September 16, 2000 WVU-CEE researchers initiated the water quality grab sampling regime in the Beaver Creek watershed by collecting grab samples at sites BC-2, $\mathrm{BC}-3, \mathrm{BC}-4, \mathrm{BC}-5, \mathrm{BC}-6$, and $\mathrm{BC}-7$. Once the water quality grab sampling regime was initiated in the Beaver Creek watershed, water quality grab samples were collected approximately every six weeks for the first five months of the sampling regime. After the first five months of the water quality grab sampling regime, water quality grab samples were collected approximately every two months from April 2001 through July 2002.

Starting on January 19, 2002, WVU-CEE researchers employed the YSI 63 handheld field meter to gather stream water quality data for additional QA/QC 
comparison of water quality data with YSI Sonde measurements. The YSI 63 handheld field meter is capable of detecting temperature, $\mathrm{pH}$, conductivity, and specific conductance.

\subsection{EXPERIMENTAL METHODS}

\subsubsection{YSI Sondes}

A protocol for calibrating and deploying the YSI sondes was created and rigorously followed during the entire period of sampling in the Beaver Creek watershed. The protocol was created in order to ensure that the water quality data being collected by the YSI sondes would be defensible.

The calibration and programming procedure from the YSI Environmental Monitoring Systems User's Manual was utilized to recalibrate and reprogram the YSI sondes before each deployment (YSI, 1999). Standard solutions from the Hach Co. were used for the calibration of the $\mathrm{pH}$, turbidity, and specific conductance probes. A computer, with the EcoWatch software loaded, was used for the calibration and programming of the YSI sondes.

During deployment, the YSI sondes were placed as near to the invert of the main channel as the data cord allowed. The YSI sondes were placed at a forty-five degree angle to the direction of flow with the probe end of the sonde pointed downstream. This orientation was chosen to optimize mixing in the probe and to minimize the sediment build up around the Sonde. After a YSI sonde was placed in its respective sampling site, it was secured with several large rocks from the streambed to ensure that the stream could not carry it away. The YSI sondes were also secured and locked to a nearby tree with a 
length of steel cable to prevent the sondes from being stolen or washed away in a flood event.

\subsubsection{Grab Sample Water Chemistry}

All methods used for water quality analyses were derived from $\underline{\text { Standard Methods }}$ for the Examination of Water and Wastewater (APHA 1998), with the exception of flow determination, which was based on a USEPA Method (USEPA 1999). The methods used to determine water quality and quantity parameters and respective detection limits are presented in Table 3.5.1 
Table 3.5.2.1 Methods Used to Determine the Water Quality and Quantity and Respective Detection Limits.

\begin{tabular}{|c|c|c|}
\hline Parameter & Standard Method & Detection Limit \\
\hline pH & $4500 \mathrm{H}^{+}-\mathrm{B}$ & -- \\
\hline Turbidity (Nephelometric) & $2130 \mathrm{~B}$ & $1 \mathrm{NTU}$ \\
\hline Total Suspended Solids & $2540 \mathrm{D}$ & $100 \mathrm{mg}$ residual filter mass \\
\hline Conductivity & $2510 \mathrm{~B}$ & $10 \mathrm{mS} / \mathrm{cm}$ \\
\hline Alkalinity & $2320 \mathrm{~B}$ & $0.75 \mathrm{mg} / \mathrm{L}$ as $\mathrm{CaCO}_{3}$ \\
\hline Acidity & $2310 \mathrm{~B}(4 \mathrm{~d})$ & $0.75 \mathrm{mg} / \mathrm{L}$ as $\mathrm{CaCO}_{3}$ \\
\hline \multirow{2}{*}{ Chloride } & $4500-\mathrm{Cl}-\mathrm{C}$ & $1.0 \mathrm{mg} / \mathrm{L}$ \\
\hline & Chloride Probe & $0.5 \mathrm{mg} / \mathrm{L}$ \\
\hline Sulfate & $4500-\mathrm{SO}_{4}-\mathrm{E}$ & $7.0 \mathrm{mg} / \mathrm{L}$ \\
\hline Iron & $3120 \mathrm{~B}$ & $0.10 \mathrm{mg} / \mathrm{L}$ \\
\hline $\begin{array}{c}\text { Calcium and Total } \\
\text { Hardness }\end{array}$ & $3120 \mathrm{~B}$ & $0.1 \mathrm{mg} / \mathrm{L}$ as $\mathrm{CaCO}_{3}$ \\
\hline Manganese & $3120 \mathrm{~B}$ & $0.10 \mathrm{mg} / \mathrm{L}$ \\
\hline Aluminum & $3120 \mathrm{~B}$ & $0.10 \mathrm{mg} / \mathrm{L}$ \\
\hline Magnesium & $3120 \mathrm{~B}$ & $0.10 \mathrm{mg} / \mathrm{L}$ \\
\hline Flow & 5.1 & $0.002 \mathrm{~m}^{3} / \mathrm{s}$ \\
\hline Ammonia & $4500-\mathrm{NH}_{3} \mathrm{G}$ & $0.01 \mathrm{mg} / \mathrm{L}$ \\
\hline Nitrate & $4501-\mathrm{NO}_{3}^{-} \mathrm{G}$ & $0.02 \mathrm{mg} / \mathrm{L}$ \\
\hline Nitrite & $4502-\mathrm{NO}_{2}^{-} \mathrm{G}$ & $0.02 \mathrm{mg} / \mathrm{L}$ \\
\hline Phosphate & 4503 - P E & 0.01 to $0.006 \mathrm{mg} / \mathrm{L}$ \\
\hline
\end{tabular}

The aforementioned analyses and procedures were chosen based on a review of the literature dealing with characterization of acidic drainage (Faulkner and Skousen 1998, Meek 1991, Murawski 1994). Aside from problems associated with low pH, acidic waters usually have significant metal concentrations (e.g., iron, aluminum, and manganese). Sulfate concentration can be detrimental as well, especially in the presence of iron (Barrett, et.al 1995a, Faulkner and Skousen 1994, and Maestri and Lord 1987). 
Analytic values below detection limits were noted in accordance with the guidelines for analyzing data with nondetects, from Guidance for Data Quality Assessment, USEPA (1998), when $<15 \%$ of the data were nondetects, it was recommended that the nondetects be replaced with one half the detection limit, the detection limit, or a very small number for statistical analysis. Throughout the analysis of water quality parameters for this study, the nondetects were managed by replacing them with one half the detection limit.

Flow rate was determined using the Global Water Flow Probe and the EM Flow Probe, by first measuring the stream bed width. The stream width was then divided into segments according to length:

- less than $5 \mathrm{~m} \rightarrow 5$ sections

- $5-10 \mathrm{~m} \rightarrow 10$ sections

- greater than $10 \mathrm{~m} \rightarrow 15$ sections.

Then the depth of the stream was measured using a meter stick at the midpoint of each division and the approximate cross-sectional area was determined. The velocity of the stream was then measured at the same location as the depth measurement at a depth of approximately one-third of the stream depth from the water surface. Using the approximate cross-sectional area of the stream and the velocity for each stream section, the flow rate for the stream was calculated (USEPA 1999).

Samples from each site were stored at zero headspace in plastic bottles and transported on ice. Six liters of water were collected at each site for total suspended solids analysis, alkalinity, $\mathrm{pH}$, conductivity, and acidity, as well as for external laboratory 
analyses (iron, calcium, manganese, aluminum, and magnesium.) Filtrate from the total suspended solids analysis was divided into four $500 \mathrm{~mL}$ containers, for sulfate, iron, chloride, calcium, magnesium and total hardness analysis, and stored in a refrigerator at 4 ${ }^{0} \mathrm{C}$ for subsequent analysis of dissolved metal concentrations. Filtrate used for iron and calcium and total hardness analyses was acidified with $2 \mathrm{~mL}$ of concentrated nitric acid prior to refrigeration.

\subsubsection{Benthic Macroinvertebrate and Fish Assessment}

An investigation of benthic macro invertebrates in Beaver Creek was conducted to establish a biological measure of suspected poor water quality conditions in the watershed. The impact of water quality on macro invertebrates and fish was established through studies of the species, size, and variety. The macroinvertebrate and fish sampling and analysis the Beaver Creek watershed was conducted by the Department of Fisheries and Wildlife and the USGS Cooperative Fisheries Research Unit at West Virginia University.

\subsubsection{Benthic Macroinvertebrate Methods}

Benthic macroinvertebrate sampling at the Beaver Creek sampling sites followed a modified version of the single habitat protocol described in the 1999 edition of Rapid Bioassessment Protocols for Use in Wadeable Streams and Rivers (Barbour et al. 1999). A 500-micron nytex dipnet with standard dimensions of $1 / 2$ meter wide by $1 / 3$ meter high was used to sample 0.25 sq. meter of riffle area. The net was placed in a riffle with the flow of stream perpendicular to the net. An area 0.5 meter by 0.5 meter was sampled. 
Large rocks were rubbed into the water flowing into the net, and the substrate was then disturbed to a maximum depth of four centimeters. Four composite samples were collected to obtain one square meter of sampled area. Samples were preserved in $95 \%$ ethanol.

Collection containers had internal and external labels. The labels contained all pertinent site data including location, date, and sample number. Samples were transported back to the laboratory. Within one week, sample fluids were drained and new preservative was added. The organisms in the sample were then sorted from debris.

Individuals within the sub sample were identified and enumerated using regional identification keys. By use of this method, the total number of organisms per square meter (density) was extrapolated from the sub-sample. These data were entered into a database and used to calculate a multi-metric index. Six metrics (EPT taxa, total taxa, \% EPT, \% chironomidae, \% top 2 dominant taxa, Hilsenhoff Family Biotic Index, HBI) were used to calculate the West Virginia Stream Condition Index (WVSCI). WVSCI ranges and corresponding steam ranks are presented in Table 3.5.31.1. 
Table 3.5.3.1.1. Classification of WVSCI Metrics (USEPA 2000).

\begin{tabular}{|c|c|}
\hline $\begin{array}{l}\text { Category } \\
\text { Specific } \\
\text { Metrics }\end{array}$ & Definition \\
\hline $\begin{array}{c}\text { Total } \\
\text { Individuals }\end{array}$ & $\begin{array}{l}\text { Total benthic macro invertebrates collected in the } \\
\text { sample }\end{array}$ \\
\hline Total EPT & $\begin{array}{l}\text { Total Ephemeroptera (mayfly nymphs), Plecoptera } \\
\text { (stonefly naiads), and Trichoptera (caddisfly larvae) }\end{array}$ \\
\hline$\%$ EPT & $\begin{array}{l}\text { Percent of sample comprised of Ephemeroptera (mayfly } \\
\text { nymphs), Plecoptera (stonefly naiads), and Trichoptera } \\
\text { (caddisfly larvae) }\end{array}$ \\
\hline$\%$ CHIRO & $\begin{array}{l}\text { Percent of sample comprised of chironomid (midge) } \\
\text { larvae pupae }\end{array}$ \\
\hline$\% 2 \mathrm{DOM}$ & $\begin{array}{l}\text { Percent of sample comprised of the } 2 \text { most abundant } \\
\text { species }\end{array}$ \\
\hline HBI & $\begin{array}{l}\text { Hilsenhoff Biotic Index, abundance-weighted average } \\
\text { tolerance of assemblage of organisms }\end{array}$ \\
\hline$\%$ Filterers & $\begin{array}{l}\text { Percent abundance of individuals belonging to the } \\
\text { "filterers" }\end{array}$ \\
\hline$\%$ Shredders & $\begin{array}{l}\text { Percent abundance of individuals belonging to the } \\
\text { "shredders" }\end{array}$ \\
\hline
\end{tabular}

WVSCI is classified into sub-sections of water quality, based on the score of the index, as very good, good, fair, poor, or very poor water quality. The rating system for WVSCI is presented in Table 3.5.3.1.2.

Table 3.5.3.1.2. The Rating System for WVSCI (USEPA 2000).

\begin{tabular}{|c|c|}
\hline WVSCI Score & Rating System of Water Quality \\
\hline $78-100$ & Very Good \\
\hline $70-77$ & Good \\
\hline $45-69$ & Fair \\
\hline $23-44$ & Poor \\
\hline $0-22$ & Very Poor \\
\hline
\end{tabular}

\subsubsection{Fisheries Evaluations Methods}

The protocol used for electrofishing surveys conducted in the Beaver Creek watershed was based on the US EPA Rapid Fish Protocols (Barbour et al. 1999). Smaller streams ( $<5 \mathrm{~m}$ average width) were sampled using a backpack electrofishing unit, and 
larger streams were sampled using a parallel wire electrofishing system. Each sample reach was located in proximity to a pre-determined water grab sample station. The exact placement of the sample reach was chosen based on two interacting factors. First, the composition of habitat types (pools, riffles, and runs) included in the sample reach was proportional to habitat types observed at the sample location. Secondly, the sample reach length was equal to approximately 40 times the stream width with a maximum of 150 meters. Reaches were located between natural barriers to limit the escape of fishes, or block nets were placed at the upstream and downstream ends of the sample reach to prevent immigration or emigration of fishes. Electrofishing proceeded upstream and triple pass depletion was utilized.

Fishes requiring laboratory identification were fixed and securely packed in jars of $10 \%$ Formalin solution. If possible, at least three individuals of all non-game species were vouchered. Location, date, collectors, and site name were included on the jar label, and recorded in a field notebook along with other pertinent information. The preservative was replaced in the sample jars after 72 hours to prevent dilution of the preservative by specimen dehydration. Regional taxonomic keys were used to identify voucher fishes.

Species abundances, number of taxa, species and total biomass, and standing stock were estimated at each sampling site. A sensitivity index and trophic guild was assigned to each species based on the "Tolerance and Trophic Guilds of Selected Fish Species" (Barbour et al. 1999). Number and percent of fishes classified as piscivore, herbivore, omnivore, filter feeder, generalist feeder, and insectivore were also calculated at each site. The Shannon-Wiener species diversity index and the percent species similarity index were calculated to make comparisons of species assemblages between 
sites. The Index of Well-Being (IWB) was also calculated for each station. The IWB was used to represent fish assemblage quality more realistically than a single diversity or abundance measure (Barbour et al. 1999). Through the Index of Biological Integrity (IBI), Karr et al. (1986) provided a consistent theoretical framework for analyzing fish assemblage data. The IBI is an aggregation of 12 biological metrics that are based on the fish assemblage's taxonomic and trophic composition and the abundance and condition of fish. Values from the seven categories were averaged to provide an IBI score for the site. Scores ranged from 1.0 to 5.0 and were ranked as good (4.0 to 5.0), fair (3.0 to 3.9), poor (2.0 to 2.9 ), and very poor (1.0 to 1.9 ) (Table 3.5.3.2.1).

Table 3.5.3.2.1. Narrative Description of Stream Biological Integrity Associated with each of the IBI Categories, taken from Table 5.5 (Roth et al. 1999).

\begin{tabular}{|l|l|l|}
\hline Rank & Score & Description \\
\hline Good & 4.0 to 5.0 & $\begin{array}{l}\text { Comparable to reference streams considered to be } \\
\text { minimally impacted. Fall within the upper } 50 \% \text { of } \\
\text { reference condition }\end{array}$ \\
\hline Fair & 3.0 to 3.9 & $\begin{array}{l}\text { Comparable to reference conditions, but some aspects of } \\
\text { biological integrity may not resemble the qualities of these } \\
\text { minimally impacted streams. Fall within the lower } \\
\text { portion of the range of reference sites (10 to 50 } \\
\text { percentile) }\end{array}$ \\
\hline Poor & 2.0 to 2.9 & $\begin{array}{l}\text { Significant deviation from reference conditions, with } \\
\text { many aspects of biological integrity not resembling the } \\
\text { qualities of these minimally impacted streams, indicating } \\
\text { some degradation }\end{array}$ \\
\hline Very Poor & 1.0 to 1.9 & $\begin{array}{l}\text { Strong deviation from reference conditions, with most } \\
\text { aspects of biological integrity not resembling the qualities } \\
\text { of these minimally impacted streams, indicating severe } \\
\text { degradation }\end{array}$ \\
\hline
\end{tabular}




\subsection{QUALITY ASSURANCE AND QUALITY CONTROL}

\subsubsection{YSI Sondes}

A quality assurance and quality control (QA/QC) program was established in order to produce defensible data from the YSI sondes in the Beaver Creek watershed. The QA/QC program consisted of the procurement of steam water quality data at the time of a YSI sonde measurement event and the comparison of at least ten percent of YSI sonde data with water quality grab sample data.

The comparison of ten percent of YSI sonde depth data with flow data from the United States Geologic Survey (USGS) gage station, located in Davis, WV, is represented in Figure 3.6.1.1 and Figure 3.6.1.2.

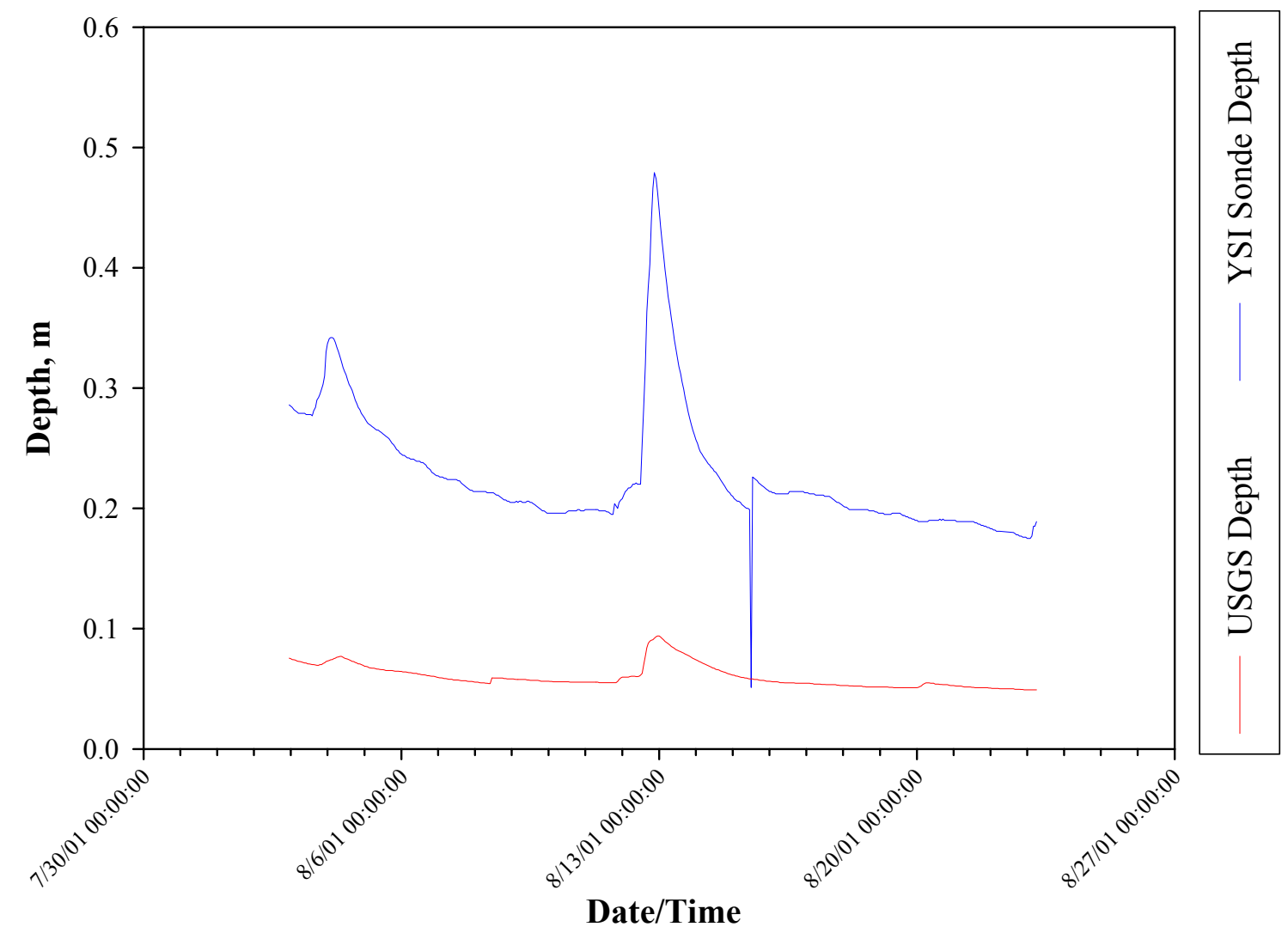

Figure 3.6.1.1. QA/QC Comparison of Depth Recorded at BC-3 by the YSI Sondes with the Depth Recorded by the USGS Gauging Station at Davis, WV. 


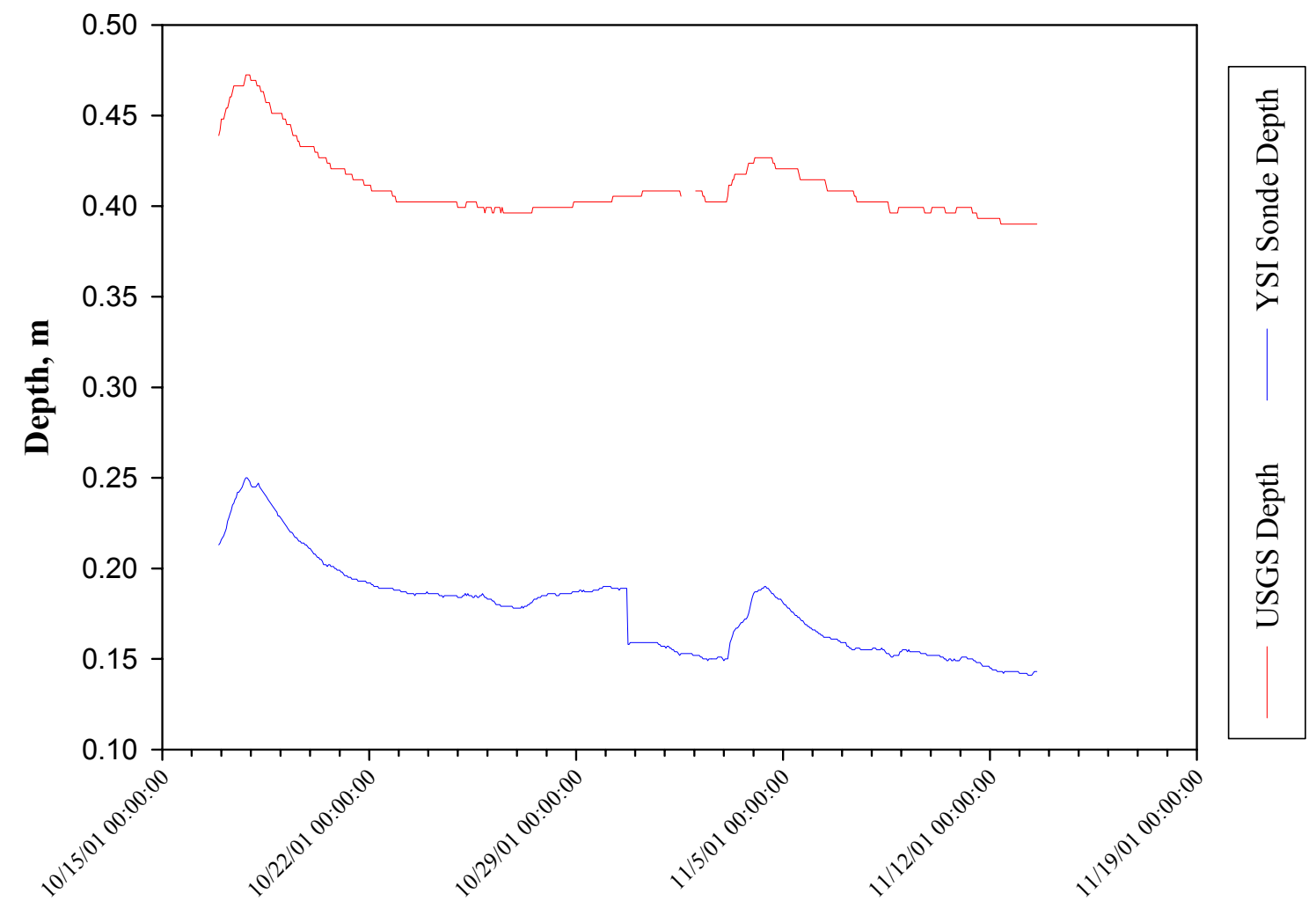

Date/Time

Figure 3.6.1.2. QA/QC Comparison of Depth at BC-9 by the YSI Sondes with Depth Recorded from the USGS Gauging Station at Davis, WV.

The conclusion that the data from both the YSI Sondes and the USGS station follow the same trends throughout the deployment period was supported by the comparison of the depth data collected from the YSI Sondes in the Beaver Creek watershed and the depth data from the USGS station at Davis, WV, as presented in Figures 3.6.1.1 and 3.6.1.2. Because of the correlation between the depth data from the YSI Sondes and the USGS station the WVU-CEE researchers were reassured that the depth data being collected by the YSI Sondes was accurate and reliable.

The QA/QC checks of $\mathrm{pH}$, temperature, specific conductance, and turbidity data from the YSI Sondes were conducted using grab sample water quality data from April 27, 
2001, August 6, 2001, September 22, 2001, and January 19, 2002. The hourly YSI Sonde data from each date, corresponding to a grab sample date to which it was compared, was averaged for the QA/QC comparison. The percent differences of the corresponding YSI Sonde values and grab sample values for each of the parameters listed above were calculated using Equation 3.6.1.1.

$$
\% \text { Error Recovery }=100 *\left|\frac{C_{\text {theo }}-C_{\text {recov }}}{C_{\text {theo }}}\right|
$$

A comparison of $\mathrm{pH}$ data from grab samples and YSI Sonde measurements is represented in Table 3.6.1.1. The percent differences between the $\mathrm{pH}$ values from the YSI Sonde and the grab sample were calculated and are also represented in Table 3.6.1.1.

Table 3.6.1.1. QA/QC on the pH Values Reported by the YSI Sondes in the Beaver Creek Watershed.

\begin{tabular}{|c|c|c|c|c|}
\hline & & & \multirow{3}{*}{$\begin{array}{c}\% \\
\text { Difference }\end{array}$} & \\
\hline & \multirow{2}{*}{$\begin{array}{l}\text { Avg pH Values from Sonde } \\
\text { Data }\end{array}$} & \multirow{2}{*}{$\begin{array}{c}\mathrm{pH} \text { Values from Grab } \\
\text { Sample Data }\end{array}$} & & \\
\hline Date & & & & Site \\
\hline $4 / 27 / 2001$ & 6.7 & 7 & 4.29 & BC-3 \\
\hline $8 / 6 / 2001$ & 3.5 & 3.4 & 2.94 & BC-8 \\
\hline $9 / 22 / 2001$ & 6.65 & 6.9 & 3.62 & BC-9 \\
\hline $1 / 19 / 2002 *$ & 6.65 & 6.73 & 1.19 & BC-3 \\
\hline
\end{tabular}

$*=$ comparison data came from YSI 63 meter

The percent differences between the YSI Sonde data and the grab sample data ranged between 1.19 and $4.29 \%$ where the highest acceptable percent difference was 10 $\%$. The correlation between the $\mathrm{pH}$ data from the YSI Sondes and the grab samples reassured the WVU-CEE researchers that the $\mathrm{pH}$ data collected by the YSI Sondes is accurate and reliable. 
A comparison of specific conductance data from grab samples and YSI Sonde measurements is represented in Table 3.6.1.2. The percent differences between the specific conductance values from the YSI Sonde and the grab sample were calculated and are also represented in Table 3.6.1.2.

Table 3.6.1.2. QA/QC on the SpCond Values Reported by the YSI Sondes in the Beaver Creek Watershed.

\begin{tabular}{|c|c|c|c|c|}
\hline & \multirow{2}{*}{$\begin{array}{l}\text { Avg SpCond from } \\
\text { Sonde Data, } \mu \mathrm{S} / \mathrm{cm}\end{array}$} & \multirow{2}{*}{$\begin{array}{l}\text { SpCond from Grab } \\
\text { Sample Data, } \mu \mathrm{S} / \mathrm{cm}\end{array}$} & \multirow{2}{*}{$\begin{array}{c}\% \\
\text { Difference }\end{array}$} & \\
\hline Date & & & & Site \\
\hline $4 / 27 / 2001$ & 320.1 & 455 & 29.6 & BC-7 \\
\hline $8 / 6 / 2001$ & 12.1 & 144 & 91.6 & BC-9 \\
\hline $9 / 22 / 2001$ & 38.1 & 88 & 56.7 & BC-1 \\
\hline $1 / 19 / 2002$ & 165 & 167 & 1.2 & BC-3 \\
\hline
\end{tabular}

A comparison of temperature data from grab sample data and YSI Sonde measurements is represented in Table 3.6.1.3. The percent differences between the temperature values from the YSI Sonde and the grab sample were calculated and are also represented in Table 3.6.1.3. While the comparison of the specific conductance data did not return compelling percent differences, the relatively low magnitude of the specific conductance values must be considered. For instance, the detectable range of range the specific conductance meters used was 0 to $100 \mathrm{mS} / \mathrm{cm}$ or $100,000 \mu \mathrm{S} / \mathrm{cm}$. 
Table 3.6.1.3. QA/QC on the Temperature Values Reported by the YSI Sondes in the Beaver Creek Watershed.

\begin{tabular}{|c|c|c|c|c|}
\cline { 4 - 5 } \multicolumn{1}{c|}{} & \multirow{2}{*}{$\begin{array}{c}\text { Avg Temp Values from } \\
\text { Sonde Data }\left({ }^{\circ} \mathrm{C}\right)\end{array}$} & $\begin{array}{c}\text { Temp Values from Grab } \\
\text { Sample Data }\left({ }^{\circ} \mathrm{C}\right)\end{array}$ & $\begin{array}{c}\% \\
\text { Difference }\end{array}$ & Site \\
\hline $4 / 27 / 2001$ & 14.8 & 15.2 & 2.6 & BC-7 \\
\hline $8 / 6 / 2001$ & 20.8 & 20.9 & 0.5 & BC-3 \\
\hline $9 / 22 / 2001$ & 12.9 & 12.7 & 1.6 & BC-1 \\
\hline $1 / 19 / 2002 *$ & 0.92 & 1.4 & 34.3 & BC-8 \\
\hline
\end{tabular}

* = comparison data came from YSI 63 meter

The percent differences between the YSI Sonde data and the grab sample data ranged between $0.5 \%$ and $2.6 \%$, with the exception of the data from January 19,2002 , where the highest acceptable percent difference is $10 \%$. The percent difference of the data from January 19, 2002 was 34.3\%, however, the values from the YSI Sonde data and the grab sample data were $0.92^{\circ} \mathrm{C}$ and $1.4^{\circ} \mathrm{C}$, respectively. The small magnitude of the temperature values from January 19, 2002 may have contributed to the elevated percent difference when calculated using equation 3.6.1.1. The correlation between the temperature data from the YSI Sondes and the grab samples reassures the WVU-CEE researchers that the temperature data collected by the YSI Sondes is accurate and reliable.

A comparison of turbidity data from grab sample data and YSI Sonde measurements is represented in Table 3.6.1.4. The percent differences between the turidity values from the YSI Sonde and the grab sample were calculated and are also represented in Table 3.6.1.4. 
Table 3.6.1.4. QA/QC on the Turbidity Values Reported by the YSI Sondes in the Beaver Creek Watershed.

\begin{tabular}{|c|c|c|c|c|}
\hline & & & \multirow{3}{*}{$\begin{array}{c}\% \\
\text { Difference }\end{array}$} & \multirow[b]{3}{*}{ Site } \\
\hline \multirow[b]{2}{*}{ Date } & \multirow{2}{*}{$\begin{array}{l}\text { Avg Turbidity Values from } \\
\text { Sonde Data (NTU) }\end{array}$} & \multirow{2}{*}{$\begin{array}{l}\text { Turbidity Values from Grab } \\
\text { Samples (NTU) }\end{array}$} & & \\
\hline & & & & \\
\hline $4 / 27 / 2001$ & 2.9 & 2.19 & 32.4 & BC-3 \\
\hline $8 / 6 / 2001$ & 9.6 & 7.9 & 21.5 & BC-9 \\
\hline 9/22/2001 & 1.7 & 0.7 & 142.9 & BC-8 \\
\hline $1 / 19 / 2002 *$ & 1.1 & 3 & 63.3 & BC-1 \\
\hline
\end{tabular}

* = comparison data came from YSI 63 meter

While none of the four sampling dates analyzed in Table 3.6.1.4 yielded a percent difference below $10 \%$ the data were still considered to be accurate. This assumption was made when the magnitude of the values analyzed from the four sampling dates were compared to the detectable ranges of the turbidity meters. For example, the detectable range of the YSI Sonde turbidity meter is 0 to 1000 NTUs (Table 3.3.1). Therefore, the values recorded from the water quality sample sites were very near the detection limit for the turbidity meters.

\subsubsection{Grab Samples}

The QA/QC protocol for grab samples consisted of triplicate sampling (on at least ten percent of all samples) and analytical recoveries (on at least ten percent of all samples) on each parameter, with the exception of total suspended solids. Triplicate samples were taken at one randomly selected site each trip. Triplicates were collected for total suspended solids analysis, however analytical recoveries could not be calculated, as the solids collected on the filter during filtration can not be duplicated in a standard solution. 
Recoveries were calculated and determined using standard solutions, following the procedure in Standard Methods for the Examination of Water and Wastewater (APHA 1998), and were reported as a "percent error". The equation used to determine the percent error in recovery is presented in Equation 3.6.2.1.

$$
\% \text { Error Recovery }=100 *\left|\frac{C_{\text {theo }}-C_{\text {re cov }}}{C_{\text {theo }}}\right|
$$

where the $\%$ error recovery is the percent error in the recovery, the theoretical concentration is the concentration calculated according to Equation 3.6.2.2, and the recovered concentration is the analytical value determined after the standard addition was made. The equation used to calculate the theoretical concentration, based on a mass balance, is presented in Equation 3.6.2.2.

$$
C_{\text {theo }}=\frac{\left(C_{\text {meas }} * V_{\text {sample }}\right)+\left(C_{\text {spike }} * V_{\text {spike }}\right)}{V_{\text {spike }}+V_{\text {sample }}}
$$

where the total volume is the volume of spike plus the volume of sample. The percent difference within the triplicates and the percent error of recovery should be below ten percent to be considered acceptable for inclusion in the data reduction process.

\subsection{STATISTICAL ANALYSES: Paired-tTest}

The performance of a statistical analysis was required in order to determine if a significant difference existed between water quality parameters for the BC-1, BC-3, and BC-6/9 sites.

Using a Paired-t Test, it is possible to examine the changes which occur before and after (or above and below) an experimental intervention on the same individuals or parameters to determine whether or not a significant difference or effect exists. 
Examining changes as opposed to the values before and after the discharge of the active mine waste treatment facility (BC-1 to $\mathrm{BC}-3)$ or above and below the confluences of suspected inputs of acid drainage (BC-3 to BC-6/9) eliminated differences due to individual responses and produced a more sensitive, powerful, test (Hayter 1996).

In order to determine whether or not the active mine drainage treatment facility and the tributaries of suspected acid drainage inputs had any effect on the water quality of Beaver Creek, the Paired-t Test was performed on the two sets of data, above and below the active mine drainage treatment facility (Sites BC-1 and BC-3) and above and below the tributaries of suspected acid drainage inputs (Sites BC-3 and BC-6/9). The data were first tested to ascertain whether they were normally distributed. If the data were normal distributed, then the Paired-t Test was performed utilizing the SigmaStat software program by SPSS (1997) at a confidence level of 0.95 and $\alpha=0.05$. The confidence interval is an interval that contains possible values for the average or mean of a set of data. An $\alpha=0.05$ is an acceptable probability of incorrectly concluding that a difference exists between data before and after an experimental intervention. A P value of 0.05 is the probability of incorrectly concluding that there is a true difference between the data before and after a particular experimental intervention.

In the process of performing a Paired-t Test, one must first determined whether the data are normally distributed. Upon verifying that the data are normally distributed, a Paired-t Test statistic can be calculated and an interpretation of the data can be made. If the data were not normally distributed, then the Paired-t Test was judged to be invalid. The existence of a statistically significant change between two data sets was determined based on a difference greater than would be expected by chance (SPSS 1997.) 
In SigmaStat, results of normality test and Paired-t Test statistics are reported at a $\mathrm{P}$ value of 0.05 . The Paired-t Test statistic was computed by determining the difference between values before and after an experimental intervention. A mean difference is then calculated, and divided by the standard error of the mean, as presented in Equation 3.7.1: $t=\frac{\mu_{\text {difference }}}{\text { stderror }_{\mu}}$

where $t$ is the Paired-t Test statistic, $\mu_{\text {difference }}$ is the mean difference between the above and below values, and std error ${ }_{\mu}$ is the standard error of the mean. The value of the t-test statistic is indicative of whether or not a statistically significant relationship exists. If the absolute value of the t-test statistic is greater than two, it is concluded that a statistically significant relationship exists. However, if the absolute value of the t-test statistic is less than two, it is concluded that a statically significant relationship does not exist between the above and below data sets (i.e., difference may be due to chance) (SPSS 1997). 


\subsection{RESULTS}

\subsection{YSI Sonde Results}

The data collected from the five YSI Sondes that were deployed in the Beaver Creek watershed are presented in graphical format due to the large volume of data. A complete set of the plots of the YSI Sonde data is presented in Appendix A including seasonal plots and plots of the entire deployment period, which began on February 14, 2001 and ended on July 12, 2002. The seasonal plots of the YSI Sonde data were delimited by the dates presented in Table 4.1.1. Plots of the data collected by the YSI Sondes at all five deployment sites during the Spring of 2001 (March 20 to June 19) are presented in Figure 4.1.1 through Figure 4.1.5 below to present the format and basic manifestation of the trends of the water quality data.

Table 4.1.1. Beginning and Ending Dates of the Seasonal Periods of Sonde Analysis.

\begin{tabular}{c|cc}
\hline Season & Beginning Date & Ending Date \\
\hline \hline Spring & March 20 & June 20 \\
Summer & June 21 & September 22 \\
Autumn & September 23 & December 21 \\
Winter & December 22 & March 19 \\
\hline
\end{tabular}

Average, maximum, and minimum values of the data collected by the YSI Sondes deployed in BC-1, BC-3, BC-7, BC-8, and BC-6/9 in the Beaver Creek watershed are presented in Table 4.1.2. 


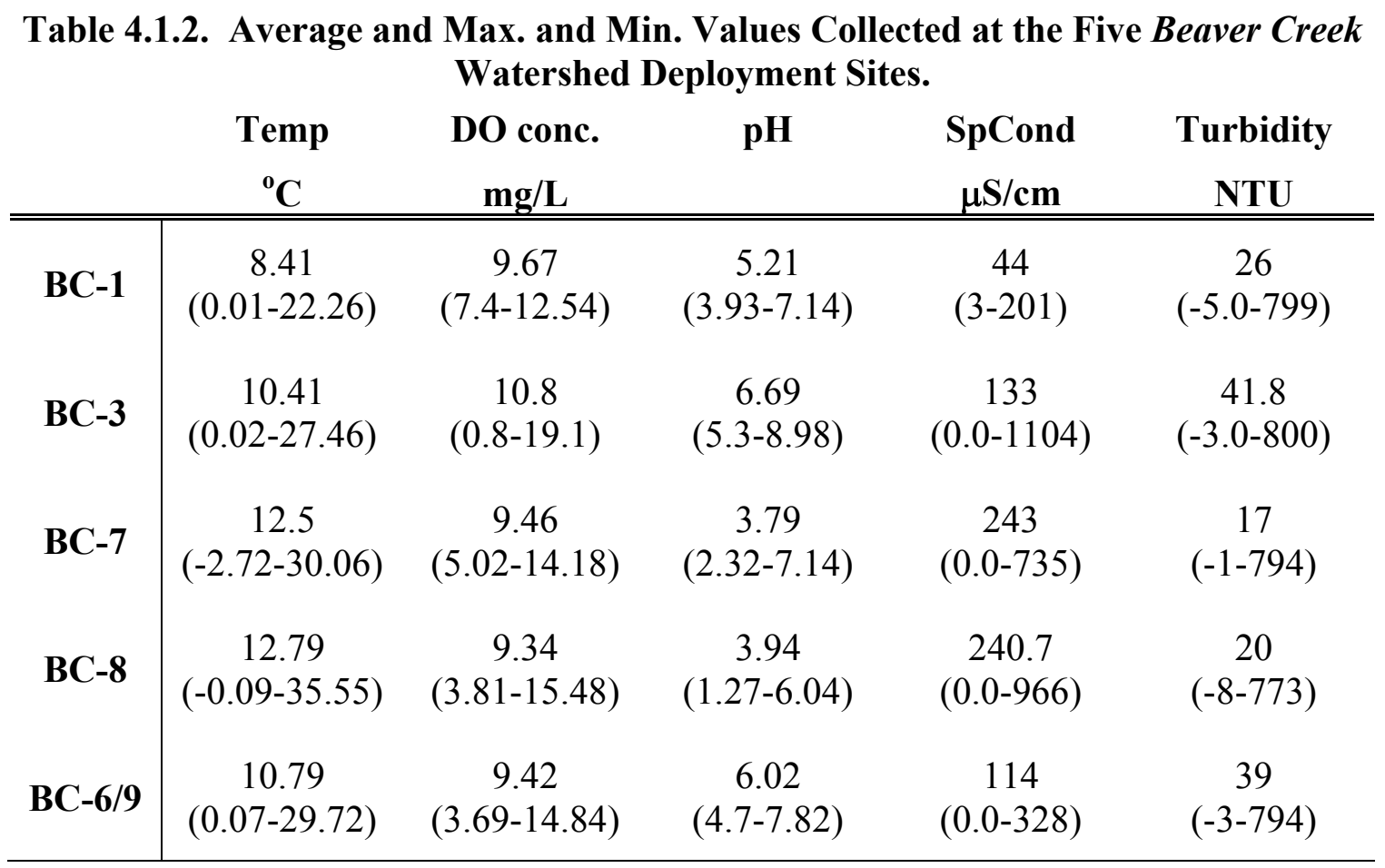

\subsubsection{Upper Beaver Creek (BC-1)}

The $\mathrm{pH}$ and specific conductance at $\mathrm{BC}-1$ averaged 5.21 with a range of 3.93 to 7.14 and $44 \mu \mathrm{S} / \mathrm{cm}$ with a range of 3 to $200.9 \mu \mathrm{S} / \mathrm{cm}$, respectively. The temperature and dissolved oxygen values collected at $\mathrm{BC}-1$ averaged $8.41^{\circ} \mathrm{C}$ with a range of 0.01 to $22.26^{\circ} \mathrm{C}$, and $9.67 \mathrm{mg} / \mathrm{L}$ with a range of 7.4 to $12.54 \mathrm{mg} / \mathrm{L}$, respectively. The turbidity values collected at BC-1 averaged 25.6 NTU with a range of -5.1 to 798.5 NTUs.

The $\mathrm{pH}$ data collected at $\mathrm{BC}-1$ fluctuated significantly over much of the study period. The specific conductance data collected at BC-1 did not fluctuate significantly with the exception of several small magnitude spikes throughout the study period. 


\subsubsection{Gatzmer (BC-3)}

The $\mathrm{pH}$ and specific conductance at $\mathrm{BC}-3$ averaged 6.69 with a range of 5.3 to 8.98 and $133.1 \mu \mathrm{S} / \mathrm{cm}$ with a range of 0.0 to $1104 \mu \mathrm{S} / \mathrm{cm}$, respectively. The temperature and dissolved oxygen values collected at $\mathrm{BC}-3$ averaged $10.41^{\circ} \mathrm{C}$ with a range of 0.02 to $27.46^{\circ} \mathrm{C}$, and $10.8 \mathrm{mg} / \mathrm{L}$ with a range of 1 to $19.1 \mathrm{mg} / \mathrm{L}$, respectively. The turbidity values collected at BC-3 averaged $41.8 \mathrm{NTU}$ with a range of -2.6 to $800 \mathrm{NTU}$.

The $\mathrm{pH}$ data collected at BC-3 did not fluctuate significantly with the exception of several small magnitude spikes throughout the study period. The specific conductance data collected at BC-3 did not fluctuate significantly with the exception of several small magnitude spikes throughout the study period.

\subsubsection{Chaffee (BC-7)}

The $\mathrm{pH}$ and specific conductance at $\mathrm{BC}-7$ averaged 3.79 with a range of 2.32 to 7.14 and $243 \mu \mathrm{S} / \mathrm{cm}$ with a range of 0.0 to $735 \mu \mathrm{S} / \mathrm{cm}$, respectively. The temperature and dissolved oxygen values collected at $\mathrm{BC}-7$ averaged $12.5^{\circ} \mathrm{C}$ with a range of -2.72 to $30.06^{\circ} \mathrm{C}$, and $9.5 \mathrm{mg} / \mathrm{L}$ with a range of 5.02 to $14.2 \mathrm{mg} / \mathrm{L}$, respectively. The turbidity values collected at BC-7 averaged 17 NTU with a range of 1 to 794 NTU.

The $\mathrm{pH}$ data collected at $\mathrm{BC}-7$ did not fluctuate significantly with the exception of several small magnitude spikes throughout the study period. The specific conductance data collected at BC-7 fluctuated significantly over much of the study period. 


\subsubsection{Hawkins (BC-8)}

The $\mathrm{pH}$ and specific conductance at $\mathrm{BC}-8$ averaged 3.94 with a range of 1.27 to 6.04 and $241 \mu \mathrm{S} / \mathrm{cm}$ with a range of 0.0 to $966 \mu \mathrm{S} / \mathrm{cm}$, respectively. The temperature and dissolved oxygen values collected at $\mathrm{BC}-8$ averaged $12.79^{\circ} \mathrm{C}$ with a range of 0.09 to $35.55^{\circ} \mathrm{C}$, and $9.3 \mathrm{mg} / \mathrm{L}$ with a range of 3.8 to $15.5 \mathrm{mg} / \mathrm{L}$, respectively. The turbidity values collected at BC-8 averaged 20 NTU with a range of -8 to 773 NTU.

The $\mathrm{pH}$ data collected at $\mathrm{BC}-8$ did not fluctuate significantly with the exception of several small magnitude spikes throughout the study period. The specific conductance data collected at BC-8 fluctuated significantly over much of the study period.

\subsubsection{Lower Beaver Creek/Davis (BC-6 \& 9)}

The $\mathrm{pH}$ and specific conductance at $\mathrm{BC}-6 / 9$ averaged 6.02 with a range of 4.7 to 7.82 and $114 \mu \mathrm{S} / \mathrm{cm}$ with a range of 0 to $328 \mu \mathrm{S} / \mathrm{cm}$, respectively. The temperature and dissolved oxygen values collected at $\mathrm{BC}-6 / 9$ averaged $10.8^{\circ} \mathrm{C}$ with a range of 0.1 to $29.7^{\circ} \mathrm{C}$, and $9.4 \mathrm{mg} / \mathrm{L}$ with a range of 3.7 to $14.5 \mathrm{mg} / \mathrm{L}$, respectively. The turbidity values collected at BC-6/9 averaged 39 NTU with a range of 0 to 794 NTU.

The $\mathrm{pH}$ data collected at BC-6/9 fluctuated significantly over much of the study period. The specific conductance data collected at BC-6/9 fluctuated significantly over much of the study period. 


\subsubsection{Probe Failures}

Of the probes on the YSI Sondes the dissolved oxygen probe and the turbidity probe were the most susceptible to contamination and/or failure. Probe failure was limited to only several occasions throughout the span of deployment periods.

Sections of questionable data and the reason for suspecting problems with the data collected at the BC-1 sampling station are presented in Table 4.1.6.1.

Table 4.1.6.1. Sections of Suspected Problematic Data and the Reason for Suspicion from $\mathrm{BC}-1$.

\begin{tabular}{|c|c|c|c|c|c|}
\hline $\begin{array}{c}\text { BC-1 } \\
\text { Questionable Data }\end{array}$ & 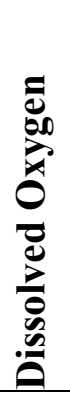 & & 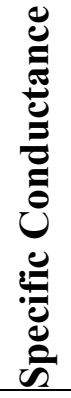 & $\frac{\pi}{2}$ & Reason \\
\hline \multicolumn{6}{|l|}{2001} \\
\hline 4/5 11:00 - 4/12 10:00 & $\mathrm{X}$ & & & & not cleaned during deployment \\
\hline $6 / 1420: 00-6 / 199: 00$ & $\mathrm{x}$ & & & & not cleaned during deployment \\
\hline $12 / 2620: 00-12 / 3123: 00$ & $\mathrm{x}$ & $\mathrm{x}$ & $\mathrm{x}$ & $\mathrm{x}$ & sonde/probe out of water \\
\hline \multicolumn{6}{|l|}{2002} \\
\hline 1/1 0:00 - 1/9 20:00 & $\mathrm{x}$ & $\mathrm{x}$ & $\mathrm{x}$ & $\mathrm{x}$ & sonde/probe out of water \\
\hline $2 / 223: 00-4 / 514: 00$ & $\mathrm{x}$ & & & & bad membrane \\
\hline 4/13 23:00 - 6/10 13:00 & $\mathrm{x}$ & & & & probe failure \\
\hline
\end{tabular}

During the February to April 2002 deployment period the dissolved oxygen probe or membrane failed completely and twice the membrane on the probe became too contaminated with sediment near the end of a deployment period to consistently collect readings. A large portion of the data collected during the deployment period of Deccember 2001 to January 2002 was compromised because the sonde was out of the stream. 
Sections of questionable data and the reason for suspecting problems with the data collected at the BC-3 sampling station are presented in Table 4.1.6.2.

Table 4.1.6.2. Sections of Suspected Problematic Data and the Reason for Suspicion from BC-3.

\begin{tabular}{|c|c|c|c|c|c|}
\hline $\begin{array}{c}\text { BC-3 } \\
\text { Questionable Data }\end{array}$ & 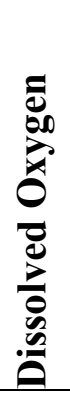 & 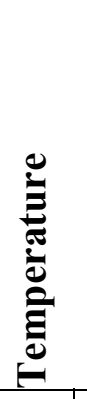 & 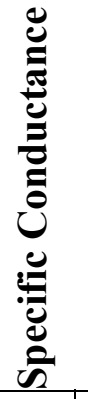 & $\bar{z}$ & Reason \\
\hline \multicolumn{6}{|l|}{2001} \\
\hline 4/8 0:00 - 4/12 7:00 & $\mathrm{x}$ & & & & not cleaned during deployment \\
\hline $5 / 811: 00-5 / 1314: 00$ & $\mathrm{x}$ & & & & not cleaned during deployment \\
\hline 7/9 0:00 - 7/28 18:00 & $\mathrm{x}$ & & & & not cleaned during deployment \\
\hline 10/26 22:00 - 10/29 2:00 & $\mathrm{x}$ & & & & sonde malfunctioned at this point \\
\hline \multicolumn{6}{|l|}{\begin{tabular}{|c|}
2002 \\
\end{tabular}} \\
\hline $2 / 24$ 13:00 - 3/17 13:00 & & & & $\mathrm{x}$ & broken $\mathrm{pH}$ bulb \\
\hline $5 / 296: 00-6 / 1015: 00$ & $\mathrm{x}$ & & & & period prior to cleaning \\
\hline
\end{tabular}

The dissolved oxygen probe was unable to collect usable data at $\mathrm{BC}-3$ on five separate occasions due to contamination of the membrane near the end of the deployment period of prior to a scheduled in-situ cleaning. During the February to April 2002 deployment period the WVU-CEE researcher discovered that the $\mathrm{pH}$ probe bulb had been broken and subsequently replaced the probe at the next available time. The data collected by the sonde during that time were therefore discarded.

Sections of questionable data and the reason for suspecting problems with the data collected at the BC-7 sampling station are presented in Table 4.1.6.3. 
Table 4.1.6.3. Sections of Suspected Problematic Data and the Reason for Suspicion from BC-7.

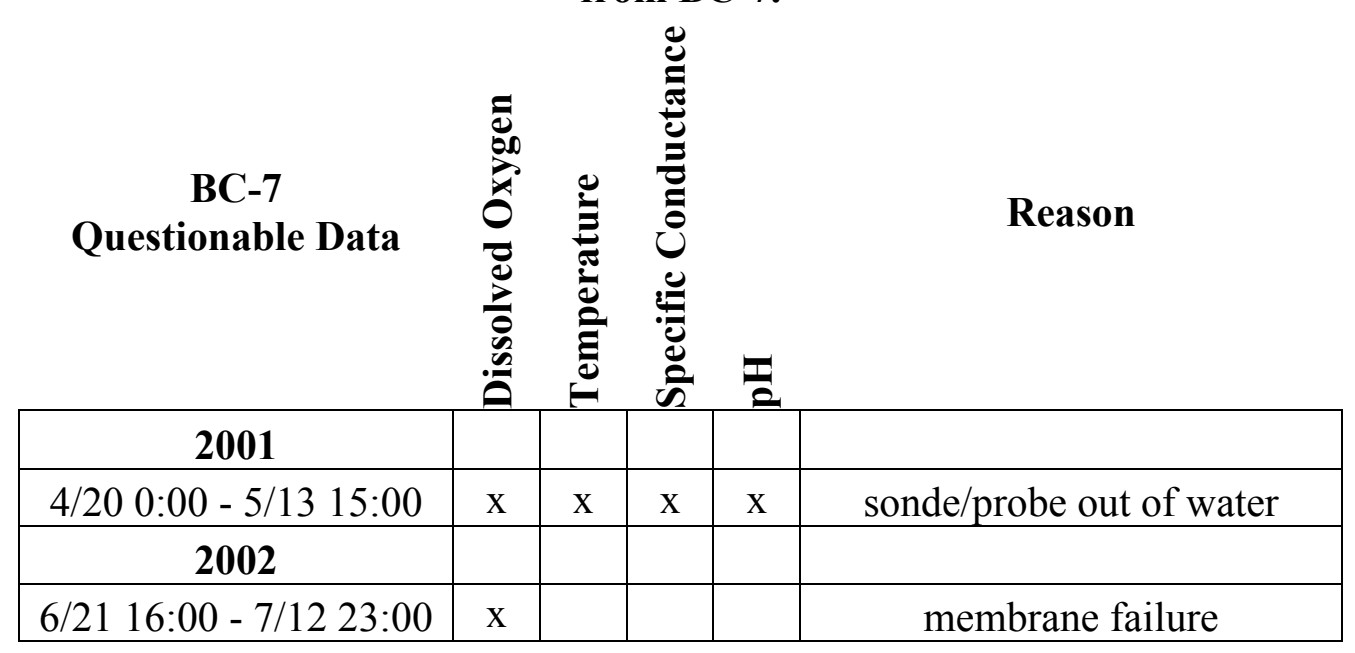

During the April 2001 deployment period the sonde at the BC-7 deployment site was dislocated from is original position and deposited in much shallower section of the stream during a high water event. As the water receded the sonde was left out of the water leading to a section of suspicious data that was subsequently removed. There was also a dissolved oxygen membrane failure near the end of the May to July 2002 deployment period.

Sections of questionable data and the reason for suspecting problems with the data collected at the BC-8 sampling station are presented in Table 4.1.6.4. 
Table 4.1.6.4. Sections of Suspected Problematic Data and the Reason for Suspicion from BC-8.

\begin{tabular}{|c|c|c|c|c|c|}
\hline $\begin{array}{c}\text { BC-8 } \\
\text { Questionable Data }\end{array}$ & 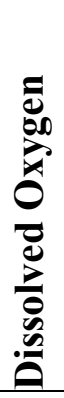 & 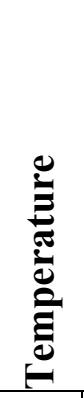 & 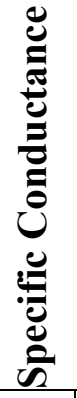 & $\frac{\pi}{2}$ & Reason \\
\hline \multicolumn{6}{|l|}{2001} \\
\hline 4/14 0:00 - 5/13 14:00 & & & $\mathrm{x}$ & $\mathrm{x}$ & probe failure \\
\hline 7/9 13:00 - 7/11 2:00 & $\mathrm{x}$ & & & & probe slip prior to cleaning \\
\hline $7 / 2415: 00-7 / 264: 00$ & $\mathrm{x}$ & & & & not cleaned during deployment \\
\hline $8 / 71: 00-8 / 1121: 00$ & $\mathrm{x}$ & & & & probe slip prior to cleaning \\
\hline 9/12 16:00 - 9/12 21:00 & $\mathrm{x}$ & & & & probe failure \\
\hline $9 / 1317: 00-9 / 142: 00$ & $\mathrm{x}$ & & & & probe failure \\
\hline 9/23 18:00 - 9/24 2:00 & $\mathrm{x}$ & & & & probe failure \\
\hline 10/16 22:00 - 11/3 16:00 & $\mathrm{x}$ & & & & bubble under membrane \\
\hline \multicolumn{6}{|l|}{2002} \\
\hline $2 / 223: 00-2 / 32: 00$ & $\mathrm{x}$ & & & & probe failure \\
\hline $3 / 40: 00-3 / 22 \quad 10: 00$ & $\mathrm{x}$ & & & & probe failure \\
\hline $5 / 42: 00-6 / 1015: 00$ & $\mathrm{x}$ & & & & probe slip prior to cleaning \\
\hline
\end{tabular}

The dissolved oxygen probe became contaminated to the point of collecting inaccurate data or malfunctioned due to the development of an air bubble under the membrane on five separate occasions. The specific conductance and $\mathrm{pH}$ probes failed to operated correctly throughout the April to May 2001 deployment period.

Sections of questionable data and the reason for suspecting problems with the data collected at the BC-6/9 sampling station are presented in Table 4.1.6.5. 
Table 4.1.6.5. Sections of Suspected Problematic Data and the Reason for Suspicion from $B C-6 / 9$.

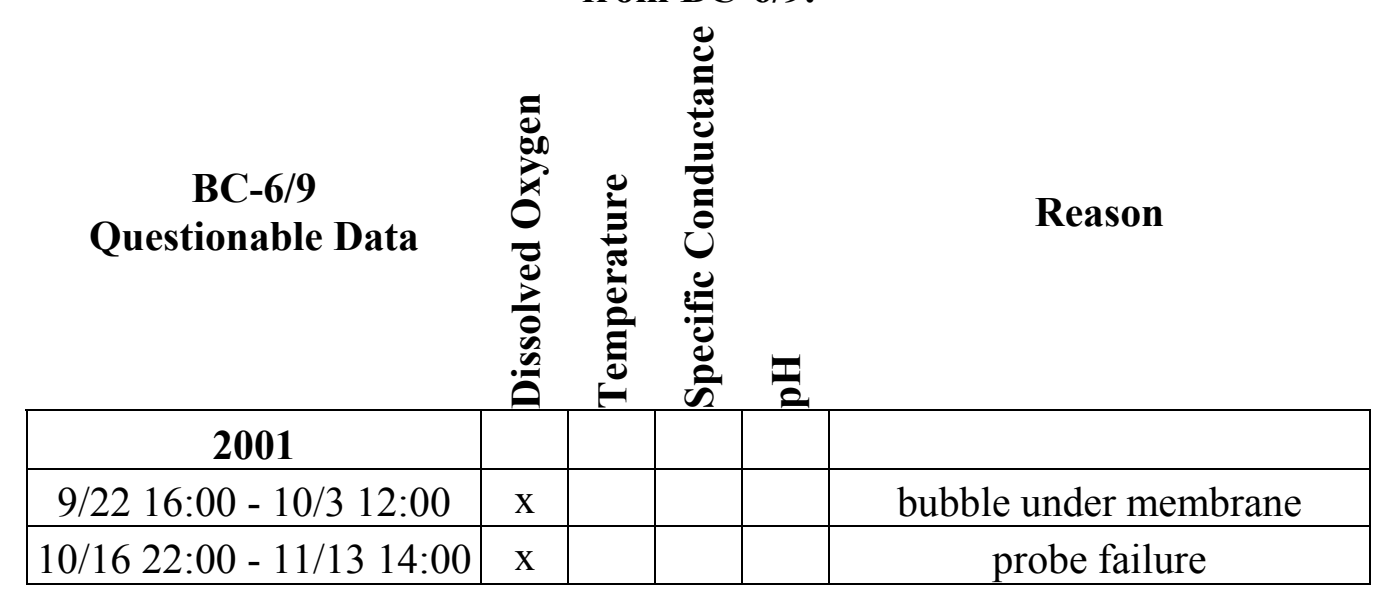

The dissolved oxygen probe failed to collect accurate data due to the development of an air bubble under the membrane during one deployment at BC-9.

The turbidity data collected from each of the deployment sites exhibited very inconsistent and suspect trends throughout each deployment period. The date trends routinely vary from the somewhat "normal" values and spike to values of 1200 to 2000 NTU and back down to the previously recorded "normal" values. In order to deal with this inconsistent behavior, WVU-CEE researchers removed all data points that lied outside the upper extreme of the calibration range, which was 800 NTUs.

Aside from the failure of probes during deployment periods, inconsistencies were observed in the depth values between some of the deployment periods. It was determined that these inconsistencies were due to the failure of research personnel to calibrate the pressure gauge at the time of deployment. Since the depth was calculated from the difference in pressure sensed by the sonde (under water) and the pressure sensed by the atmospheric pressure gauge on the data cord (above water) the observed trends in the 
depth data were accurate but the range of values or magnitude of the values may have been inaccurate.

\subsection{Water Quality Grab Sample Results}

Water quality grab samples were collected and evaluated at each of the eight water quality sampling sites in the Beaver Creek watershed as described previously in Section 3.4.2 (Sampling Regime) and Section 3.5.2 (Experimental Methods). The results of the aforementioned collection and evaluation of the water quality grab samples are summarized in the following section.

A set of criteria was used to assist the characterization the water quality data collected at each sampling station. The criteria used was a set of standards used to classify a body of water as capable of supporting aquatic organisms. The minimum water quality criteria needed to support aquatic life is presented in Table 4.2.1. (Jenkins et al. 1995)

Table 4.2.1. Summary of Standard Water Quality Criteria for Freshwater Organisms (Jenkins et al. 1995).

\begin{tabular}{|c|c|}
\hline Water Quality Parameter & Criteria \\
\hline Alkalinity & $10-400 \mathrm{mg} / \mathrm{L}\left(\right.$ as $\left.\mathrm{CaCO}_{3}\right)$ \\
\hline Total Hardness & $10-400 \mathrm{mg} / \mathrm{L}(\mathrm{as} \mathrm{CaCO} 3)$ \\
\hline Iron (dissolved) & $<1.5 \mathrm{mg} / \mathrm{L}^{2}$ \\
\hline Total Suspended Solids & $<80 \mathrm{mg} / \mathrm{L}$ \\
\hline $\mathrm{pH}$ & $6.5-8.0 \mathrm{units}$ \\
\hline Sulfate & $<850 \mathrm{mg} / \mathrm{L}$ \\
\hline Aluminum & $<87 \mu \mathrm{gg} / \mathrm{L}^{1}$ or $<0.087 \mathrm{mg} / \mathrm{L}^{2}$ \\
\hline Chloride & $<860 \mathrm{mg} / \mathrm{L}^{1}$ or $<230 \mathrm{mg} / \mathrm{L}^{2}$ \\
\hline Nitrite (as Nitrite-N) & $<1.0 \mathrm{mg} / \mathrm{L}^{1}$ \\
\hline Manganese & $<1.0 \mathrm{mg} / \mathrm{L}$ \\
\hline
\end{tabular}

${ }^{1}$ acute exposure to the given parameter, the average concentration for one hour, which should not be exceeded more than once during a three year period.

${ }^{2}$ chronic exposure to the given parameter, the average concentration for four days, which should not be exceeded more than once during a three year period. 
The results of the water quality sampling of the Beaver Creek watershed are presented in the following subsections. The complete data set is presented in tabular form by water quality grab sampling site in Appendix B.

\subsubsection{Upper Beaver Creek (BC-1)}

The air and water temperature averaged $10.2{ }^{\circ} \mathrm{C}$ with a range of -0.5 to $27.6{ }^{\circ} \mathrm{C}$ and $7.4{ }^{\circ} \mathrm{C}$ with a range of 0.8 to $19.7{ }^{\circ} \mathrm{C}$, respectively. The turbidity and TSS averaged 2.9 NTUs with a range of 0.8 to 14.6 NTUs and $1.68 \mathrm{mg} / \mathrm{L}$ with a range of 0.15 to 5.35 $\mathrm{mg} / \mathrm{L}$, respectively. The stream at BC-1 had an average flow rate of $0.102 \mathrm{~m}^{3} / \mathrm{sec}$ with a range of 0.003 to $0.80 \mathrm{~m}^{3} / \mathrm{sec}$. The $\mathrm{pH}$ and conductivity averaged 5.12 with a range of 4.50 to 6.10 and $59.9 \mu \mathrm{S} / \mathrm{cm}$ with a range of 28.7 to $104.6 \mu \mathrm{S} / \mathrm{cm}$, respectively. The alkalinity and acidity averaged $12.26 \mathrm{mg} / \mathrm{L}$ as $\mathrm{CaCO}_{3}$ with a range of 1.56 to $18.48 \mathrm{mg} / \mathrm{L}$ as $\mathrm{CaCO}_{3}$ and $12.0 \mathrm{mg} / \mathrm{L}$ as $\mathrm{CaCO}_{3}$ with a range of 5.17 to $46.2 \mathrm{mg} / \mathrm{L}$ as $\mathrm{CaCO}_{3}$, respectively. The water collected at $\mathrm{BC}-1$ averaged $11.5 \mathrm{mg} / \mathrm{L}$ of sulfate with a range of 7.51 to $23.6 \mathrm{mg} / \mathrm{L}$. The average value of iron found at $\mathrm{BC}-1$ was $0.22 \mathrm{mg} / \mathrm{L}$ with a range of 0.13 to $0.31 \mathrm{mg} / \mathrm{L}$. The values of calcium and magnesium averaged $4.78 \mathrm{mg} / \mathrm{L}$ with a range of 1.37 to $19.0 \mathrm{mg} / \mathrm{L}$ and $0.45 \mathrm{mg} / \mathrm{L}$ with a range of 0.24 to $0.88 \mathrm{mg} / \mathrm{L}$, respectively. The values of manganese and aluminum averaged $0.07 \mathrm{mg} / \mathrm{L}$ with a range of 0.01 to $0.29 \mathrm{mg} / \mathrm{L}$ and $0.90 \mathrm{mg} / \mathrm{L}$ with a range of 0.0 to $8.0 \mathrm{mg} / \mathrm{L}$, respectively. The chloride in the water collected at BC-1 averaged $6.69 \mathrm{mg} / \mathrm{L}$ with a range of 1.30 to 21.7 $\mathrm{mg} / \mathrm{L}$. Values of nitrite at BC-1 were consistently below detectable limits. The values of nitrate found at BC-1 averaged $0.04 \mathrm{mg} / \mathrm{L}$ with a range of 0.02 to $0.07 \mathrm{mg} / \mathrm{L}$. Values of 
ammonia and phosphate were found to average $0.01 \mathrm{mg} / \mathrm{L}$ with no range and $0.016 \mathrm{mg} / \mathrm{L}$ with a range of 0.005 to $0.027 \mathrm{mg} / \mathrm{L}$, respectively.

The flow at BC-1 was low because this site was located near the headwaters of Beaver Creek. The $\mathrm{pH}$ and conductivity at $\mathrm{BC}-1$ were both low. Both the alkalinity and acidity were low at BC-1, which means that the water at BC-1 had little ability to buffer against changes in $\mathrm{pH}$. The nutrient concentrations at $\mathrm{BC}-1$ were low and the metals concentrations were high.

\subsubsection{Elder Swamp (BC-2)}

The air and water temperature averaged $10.1{ }^{\circ} \mathrm{C}$ with a range of -0.3 to $23.9^{\circ} \mathrm{C}$ and $9.3{ }^{\circ} \mathrm{C}$ with a range of 0.3 to $23.4{ }^{\circ} \mathrm{C}$, respectively. The turbidity and TSS averaged 3.1 NTUs with a range of 0.6 to $7.2 \mathrm{NTUs}$ and $4.07 \mathrm{mg} / \mathrm{L}$ with a range of 0.55 to 11.1 $\mathrm{mg} / \mathrm{L}$, respectively. The stream at $\mathrm{BC}-2$ had an average flow rate of $0.97 \mathrm{~m}^{3} / \mathrm{sec}$ with a range of 0.230 to $1.710 \mathrm{~m}^{3} / \mathrm{sec}$. The $\mathrm{pH}$ and conductivity averaged 6.1 with a range of 5.2 to 6.9 and $333.1 \mu \mathrm{S} / \mathrm{cm}$ with a range of 11.1 to $1027.0 \mu \mathrm{S} / \mathrm{cm}$, respectively. The alkalinity and acidity averaged $19.8 \mathrm{mg} / \mathrm{L}$ as $\mathrm{CaCO}_{3}$ with a range of 2.0 to $33.3 \mathrm{mg} / \mathrm{L}$ as $\mathrm{CaCO}_{3}$ and $19.6 \mathrm{mg} / \mathrm{L}$ as $\mathrm{CaCO}_{3}$ with a range of 0.5 to $110.0 \mathrm{mg} / \mathrm{L}$ as $\mathrm{CaCO}_{3}$, respectively. The water collected at BC-2 averaged $131.3 \mathrm{mg} / \mathrm{L}$ of sulfate with a range of 10.9 to $285.0 \mathrm{mg} / \mathrm{L}$. The average value of iron at BC-2 was $0.63 \mathrm{mg} / \mathrm{L}$ with a range of 0.16 to $1.53 \mathrm{mg} / \mathrm{L}$. The values of calcium and magnesium averaged $28.7 \mathrm{mg} / \mathrm{L}$ with a range of 2.0 to $68.2 \mathrm{mg} / \mathrm{L}$ and $8.9 \mathrm{mg} / \mathrm{L}$ with a range of 0.6 to $17.4 \mathrm{mg} / \mathrm{L}$, respectively.

The values of manganese and aluminum averaged $1.54 \mathrm{mg} / \mathrm{L}$ with a range of 0.11 to 3.48 $\mathrm{mg} / \mathrm{L}$ and $0.19 \mathrm{mg} / \mathrm{L}$ with a range of 0.10 to $0.30 \mathrm{mg} / \mathrm{L}$, respectively. The chloride in the 
water collected at BC-2 averaged $3.12 \mathrm{mg} / \mathrm{L}$ with a range of 0.75 to $8.75 \mathrm{mg} / \mathrm{L}$. Values of nitrite and nitrate at BC-2 averaged $0.04 \mathrm{mg} / \mathrm{L}$ with a range of 0.02 to $0.06 \mathrm{mg} / \mathrm{L}$ and $0.38 \mathrm{mg} / \mathrm{L}$ with a range of 0.05 to $1.20 \mathrm{mg} / \mathrm{L}$, respectively. Values of ammonia and phosphate averaged $19.2 \mathrm{mg} / \mathrm{L}$ with a range of 0.37 to $42.2 \mathrm{mg} / \mathrm{L}$ and $0.032 \mathrm{mg} / \mathrm{L}$ with a range of 0.010 to $0.059 \mathrm{mg} / \mathrm{L}$, respectively.

The flow at BC-2 was low because this site was just below the headwaters of Beaver Creek. The alkalinity and acidity were approximately equal at BC-2, which means that the water at this site was weakly buffered against changes in $\mathrm{pH}$. The nutrient concentrations at $\mathrm{BC}-2$ were low and the metals concentrations were generally high.

\subsubsection{Gatzmer (BC-3)}

The air and water temperature averaged $10.3^{\circ} \mathrm{C}$ with a range of -0.2 to $34.5^{\circ} \mathrm{C}$ and $8.3{ }^{\circ} \mathrm{C}$ with a range of 0.4 to $21.3{ }^{\circ} \mathrm{C}$, respectively. The turbidity and TSS averaged 3.0 NTUs with a range of 1.0 to 5.0 NTUs and $2.45 \mathrm{mg} / \mathrm{L}$ with a range of 0.45 to 7.40 $\mathrm{mg} / \mathrm{L}$, respectively. The stream at BC-3 had an average flow rate of $0.740 \mathrm{~m}^{3} / \mathrm{sec}$ with a range of 0.058 to $3.970 \mathrm{~m}^{3} / \mathrm{sec}$. The $\mathrm{pH}$ and conductivity averaged 6.5 with a range of 5.0 to 7.3 and $143.4 \mu \mathrm{S} / \mathrm{cm}$ with a range of 76.4 to $381.0 \mu \mathrm{S} / \mathrm{cm}$, respectively. The alkalinity and acidity averaged $21.7 \mathrm{mg} / \mathrm{L}$ as $\mathrm{CaCO}_{3}$ with a range of 6.6 to $34.1 \mathrm{mg} / \mathrm{L}$ as $\mathrm{CaCO}_{3}$ and $15.4 \mathrm{mg} / \mathrm{L}$ as $\mathrm{CaCO}_{3}$ with a range of 0.0 to $158.0 \mathrm{mg} / \mathrm{L}$ as $\mathrm{CaCO}_{3}$, respectively. The water collected at BC-3 averaged $43.2 \mathrm{mg} / \mathrm{L}$ of sulfate with a range of 20.2 to $135.1 \mathrm{mg} / \mathrm{L}$. The average value of iron found at BC-3 was $1.99 \mathrm{mg} / \mathrm{L}$ with a range of 0.16 to $16.6 \mathrm{mg} / \mathrm{L}$. The values of calcium and magnesium averaged $15.2 \mathrm{mg} / \mathrm{L}$ with a range of 0.48 to $36.4 \mathrm{mg} / \mathrm{L}$ and $3.51 \mathrm{mg} / \mathrm{L}$ with a range of 0.05 to $16.8 \mathrm{mg} / \mathrm{L}$, 
respectively. The values of manganese and aluminum averaged $0.72 \mathrm{mg} / \mathrm{L}$ with a range of 0.09 to $2.91 \mathrm{mg} / \mathrm{L}$ and $0.33 \mathrm{mg} / \mathrm{L}$ with a range of 0.10 to $1.40 \mathrm{mg} / \mathrm{L}$, respectively. The chloride in the water collected at BC-3 averaged $4.41 \mathrm{mg} / \mathrm{L}$ with a range of 1.50 to 7.50 $\mathrm{mg} / \mathrm{L}$. Values of nitrite and nitrate at BC-3 averaged $0.18 \mathrm{mg} / \mathrm{L}$ with a range of 0.03 to $0.48 \mathrm{mg} / \mathrm{L}$ and $0.41 \mathrm{mg} / \mathrm{L}$ with a range of 0.23 to $0.80 \mathrm{mg} / \mathrm{L}$, respectively. Values of ammonia and phosphate were found to average $2.23 \mathrm{mg} / \mathrm{L}$ with a range of 0.10 to 12.5 $\mathrm{mg} / \mathrm{L}$ and $0.061 \mathrm{mg} / \mathrm{L}$ with a range of 0.002 to $0.477 \mathrm{mg} / \mathrm{L}$, respectively.

The flow at BC-3 was moderate because this site was at the mid-point of the main channel of Beaver Creek. The stream at BC-3 was net alkaline, which means that the water was buffered against changes in $\mathrm{pH}$. The nutrient concentrations at BC-3 were high and the metals concentrations were high.

\subsubsection{Iron Pond (BC-4)}

The air and water temperature averaged $10.7^{\circ} \mathrm{C}$ with a range of 0.0 to $25.8^{\circ} \mathrm{C}$ and $9.8{ }^{\circ} \mathrm{C}$ with a range of -0.2 to $18.9^{\circ} \mathrm{C}$, respectively. The turbidity and TSS averaged 1.8 NTUs with a range of 0.3 to $5.5 \mathrm{NTUs}$ and $3.02 \mathrm{mg} / \mathrm{L}$ with a range of 0.20 to $7.35 \mathrm{mg} / \mathrm{L}$, respectively. The flow rate was never measured at BC-4 due to the fact that the sampling site for BC-4 is located in an impoundment therefore a value of flow rate would be of no signifigance. The $\mathrm{pH}$ and conductivity averaged 4.2 with a range of 2.8 to 6.2 and 286.2 $\mu \mathrm{S} / \mathrm{cm}$ with a range of 102.8 to $456.0 \mu \mathrm{S} / \mathrm{cm}$, respectively. The alkalinity and acidity averaged $13.6 \mathrm{mg} / \mathrm{L}$ as $\mathrm{CaCO}_{3}$ with a range of 0.0 to $20.0 \mathrm{mg} / \mathrm{L}$ as $\mathrm{CaCO}_{3}$ and $34.5 \mathrm{mg} / \mathrm{L}$ as $\mathrm{CaCO}_{3}$ with a range of 4.0 to $81.4 \mathrm{mg} / \mathrm{L}$ as $\mathrm{CaCO}_{3}$, respectively. The water collected at BC-4 averaged $120.3 \mathrm{mg} / \mathrm{L}$ of sulfate with a range of 40.5 to $188.0 \mathrm{mg} / \mathrm{L}$. The average 
value of iron found at BC-4 was $2.83 \mathrm{mg} / \mathrm{L}$ with a range of 0.67 to $7.38 \mathrm{mg} / \mathrm{L}$. The values of calcium and magnesium averaged $23.4 \mathrm{mg} / \mathrm{L}$ with a range of 11.2 to $64.2 \mathrm{mg} / \mathrm{L}$ and $8.50 \mathrm{mg} / \mathrm{L}$ with a range of 1.01 to $13.4 \mathrm{mg} / \mathrm{L}$, respectively. The values of manganese and aluminum averaged $3.00 \mathrm{mg} / \mathrm{L}$ with a range of 1.03 to $13.0 \mathrm{mg} / \mathrm{L}$ and $2.69 \mathrm{mg} / \mathrm{L}$ with a range of 0.50 to $8.40 \mathrm{mg} / \mathrm{L}$, respectively. The chloride in the water collected at $\mathrm{BC}-4$ averaged $2.09 \mathrm{mg} / \mathrm{L}$ with a range of 0.25 to $6.50 \mathrm{mg} / \mathrm{L}$. The values of nitrite at BC-4 were found to be consistently below detectible limits. Values of nitrate at BC-4 averaged $0.024 \mathrm{mg} / \mathrm{L}$ with a range of 0.02 to $0.03 \mathrm{mg} / \mathrm{L}$. Values of ammonia and phosphate were found to average $0.027 \mathrm{mg} / \mathrm{L}$ with a range of 0.016 to $0.05 \mathrm{mg} / \mathrm{L}$ and $0.028 \mathrm{mg} / \mathrm{L}$ with a range of 0.005 to $0.044 \mathrm{mg} / \mathrm{L}$, respectively.

The flow at BC-4 was very low because this site was in a pond on a tributary of Beaver Creek. The $\mathrm{pH}$ and conductivity at this site were both low at BC-4. The stream at BC-4 was net acidic, which means that the water at BC-4 was not buffered against changes in $\mathrm{pH}$. The nutrient concentrations at $\mathrm{BC}-4$ were low and the metals concentrations were high.

\subsubsection{Slate Culvert (BC-5)}

The air and water temperature averaged $11.6{ }^{\circ} \mathrm{C}$ with a range of 0.6 to $26.9{ }^{\circ} \mathrm{C}$ and $10.3{ }^{\circ} \mathrm{C}$ with a range of 0.3 to $26.8{ }^{\circ} \mathrm{C}$, respectively. The turbidity and TSS averaged 2.0 NTUs with a range of 0.0 to 10.0 NTUs and $1.9 \mathrm{mg} / \mathrm{L}$ with a range of 0.0 to $8.6 \mathrm{mg} / \mathrm{L}$, respectively. The stream at $\mathrm{BC}-5$ had an average flow rate of $0.005 \mathrm{~m}^{3} / \mathrm{sec}$ with a range of 0.001 to $0.013 \mathrm{~m}^{3} / \mathrm{sec}$. The $\mathrm{pH}$ and conductivity averaged 2.9 with a range of 2.1 to 3.3 and $734.0 \mu \mathrm{S} / \mathrm{cm}$ with a range of 129.0 to $1107.0 \mu \mathrm{S} / \mathrm{cm}$, respectively. There was no 
alkalinity found in the water at $\mathrm{BC}-5$ because the $\mathrm{pH}$ was below the methyl orange endpoint used in the analysis of alkalinity. Values of acidity were found to average 129.5 $\mathrm{mg} / \mathrm{L}$ as $\mathrm{CaCO}_{3}$ with a range of 18.0 to $171.6 \mathrm{mg} / \mathrm{L}$ as $\mathrm{CaCO}_{3}$. The water collected at BC-5 averaged $207.0 \mathrm{mg} / \mathrm{L}$ of sulfate with a range of 61.2 to $356.0 \mathrm{mg} / \mathrm{L}$. The average value of iron found at BC-5 was $8.85 \mathrm{mg} / \mathrm{L}$ with a range of 3.68 to $16.3 \mathrm{mg} / \mathrm{L}$. The values of calcium and magnesium averaged $16.6 \mathrm{mg} / \mathrm{L}$ with a range of 6.88 to $49.4 \mathrm{mg} / \mathrm{L}$ and $19.3 \mathrm{mg} / \mathrm{L}$ with a range of 0.61 to $31.7 \mathrm{mg} / \mathrm{L}$, respectively. The values of manganese and aluminum averaged $5.81 \mathrm{mg} / \mathrm{L}$ with a range of 3.87 to $8.11 \mathrm{mg} / \mathrm{L}$ and $6.87 \mathrm{mg} / \mathrm{L}$ with a range of 3.40 to $9.29 \mathrm{mg} / \mathrm{L}$, respectively. The chloride in the water collected at $\mathrm{BC}-5$ averaged $2.44 \mathrm{mg} / \mathrm{L}$ with a range of BDL to $11.0 \mathrm{mg} / \mathrm{L}$. Values of nitrite at BC-5 were found to be consistently below detectable limits. The values of nitrate at BC-5 averaged $0.07 \mathrm{mg} / \mathrm{L}$ with a range of 0.01 to $0.18 \mathrm{mg} / \mathrm{L}$. Values of ammonia and phosphate were found to average $0.10 \mathrm{mg} / \mathrm{L}$ with a range of 0.01 to $0.18 \mathrm{mg} / \mathrm{L}$ and $0.056 \mathrm{mg} / \mathrm{L}$ with a range of 0.003 to $0.107 \mathrm{mg} / \mathrm{L}$, respectively.

The flow at BC-5 was low because this site was located on a small tributary of Beaver Creek. The $\mathrm{pH}$ values at $\mathrm{BC}-5$ were low and the conductivity values at $\mathrm{BC}-5$ were high. The values of alkalinity were very low and the values of acidity were very high at $\mathrm{BC}-5$, which means that the water at this site was very poorly buffered and acidic. The nutrient concentrations at $\mathrm{BC}-5$ were low except for phosphates and the metals concentrations at this site were high. 


\subsubsection{Chaffee (BC-7)}

The air and water temperature averaged $15.0{ }^{\circ} \mathrm{C}$ with a range of 3.1 to $29.8^{\circ} \mathrm{C}$ and $13.9^{\circ} \mathrm{C}$ with a range of 2.2 to $25.0{ }^{\circ} \mathrm{C}$, respectively. The turbidity and TSS averaged 2.7 NTUs with a range of 0.4 to 7.0 NTUs and $3.11 \mathrm{mg} / \mathrm{L}$ with a range of 0.70 to $8.89 \mathrm{mg} / \mathrm{L}$, respectively. The stream at $\mathrm{BC}-7$ had an average flow rate of $0.01 \mathrm{~m}^{3} / \mathrm{sec}$ with a range of BDL to $0.25 \mathrm{~m}^{3} / \mathrm{sec}$. The $\mathrm{pH}$ and conductivity averaged 3.8 with a range of 3.4 to 4.4 and $304.7 \mu \mathrm{S} / \mathrm{cm}$ with a range of 148.9 to $458.2 \mu \mathrm{S} / \mathrm{cm}$, respectively. The alkalinity and acidity averaged $6.93 \mathrm{mg} / \mathrm{L}$ as $\mathrm{CaCO}_{3}$ with a range of 0.0 to $15.0 \mathrm{mg} / \mathrm{L}$ as $\mathrm{CaCO}_{3}$ and $56.58 \mathrm{mg} / \mathrm{L}$ as $\mathrm{CaCO}_{3}$ with a range of 16.0 to $86.7 \mathrm{mg} / \mathrm{L}$ as $\mathrm{CaCO}_{3}$, respectively. The water collected at $\mathrm{BC}-7$ averaged $101.0 \mathrm{mg} / \mathrm{L}$ of sulfate with a range of 43.0 to 161.0 $\mathrm{mg} / \mathrm{L}$. The average value of iron found at BC-7 was $2.36 \mathrm{mg} / \mathrm{L}$ with a range of 0.52 to $5.83 \mathrm{mg} / \mathrm{L}$. The values of calcium and magnesium averaged $10.0 \mathrm{mg} / \mathrm{L}$ with a range of 3.79 to $19.1 \mathrm{mg} / \mathrm{L}$ and $9.84 \mathrm{mg} / \mathrm{L}$ with a range of 4.97 to $13.4 \mathrm{mg} / \mathrm{L}$, respectively. The values of manganese and aluminum averaged $3.17 \mathrm{mg} / \mathrm{L}$ with a range of 0.67 to 5.84 $\mathrm{mg} / \mathrm{L}$ and $3.14 \mathrm{mg} / \mathrm{L}$ with a range of 2.30 to $9.60 \mathrm{mg} / \mathrm{L}$, respectively. The chloride in the water collected at BC-7 averaged $0.77 \mathrm{mg} / \mathrm{L}$ with a range of 0.0 to $1.90 \mathrm{mg} / \mathrm{L}$. Values of nitrite in the water collected at $\mathrm{BC}-7$ were found to be consistently below detectable limits. The values of nitrate at $\mathrm{BC}-7$ averaged $0.066 \mathrm{mg} / \mathrm{L}$ with a range of 0.02 to 0.19 $\mathrm{mg} / \mathrm{L}$. Values of ammonia and phosphate were found to average $0.25 \mathrm{mg} / \mathrm{L}$ with a range of 0.02 to $1.08 \mathrm{mg} / \mathrm{L}$ and $0.030 \mathrm{mg} / \mathrm{L}$ with a range of 0.003 to $0.051 \mathrm{mg} / \mathrm{L}$, respectively.

The flow at BC-7 was low because this site was on a tributary of Beaver Creek. The $\mathrm{pH}$ and conductivity at this site were both low. The values of alkalinity were low and the values of acidity were slightly high at $\mathrm{BC}-7$, which means that the water at this 
site was acidic. The nutrient concentrations at $\mathrm{BC}-7$ were low and the metals concentrations at this site were high.

\subsubsection{Hawkins (BC-8)}

The air and water temperature averaged $15.1{ }^{\circ} \mathrm{C}$ with a range of 5.8 to $27.3{ }^{\circ} \mathrm{C}$ and $14.5{ }^{\circ} \mathrm{C}$ with a range of 3.6 to $27.8^{\circ} \mathrm{C}$, respectively. The turbidity and TSS averaged 2.2 NTUs with a range of 0.6 to 6.0 NTUs and $2.93 \mathrm{mg} / \mathrm{L}$ with a range of 0.6 to $13.0 \mathrm{mg} / \mathrm{L}$, respectively. The stream at $\mathrm{BC}-8$ had an average flow rate of $0.071 \mathrm{~m}^{3} / \mathrm{sec}$ with a range of 0.028 to $0.141 \mathrm{~m}^{3} / \mathrm{sec}$. The $\mathrm{pH}$ and conductivity averaged 4.1 with a range of 3.4 to 4.7 and $260.1 \mu \mathrm{S} / \mathrm{cm}$ with a range of 122.6 to $415.0 \mu \mathrm{S} / \mathrm{cm}$, respectively. The alkalinity and acidity averaged $9.10 \mathrm{mg} / \mathrm{L}$ as $\mathrm{CaCO}_{3}$ with a range of 0.0 to $16.4 \mathrm{mg} / \mathrm{L}$ as $\mathrm{CaCO}_{3}$ and $41.0 \mathrm{mg} / \mathrm{L}$ as $\mathrm{CaCO}_{3}$ with a range of 16.6 to $72.0 \mathrm{mg} / \mathrm{L}$ as $\mathrm{CaCO}_{3}$, respectively. The water collected at BC-8 averaged $102.4 \mathrm{mg} / \mathrm{L}$ of sulfate with a range of 55.3 to 157.0 $\mathrm{mg} / \mathrm{L}$. The average value of iron found at $\mathrm{BC}-8$ was $1.59 \mathrm{mg} / \mathrm{L}$ with a range of 0.42 to $8.26 \mathrm{mg} / \mathrm{L}$. The values of calcium and magnesium averaged $13.9 \mathrm{mg} / \mathrm{L}$ with a range of 4.52 to $26.8 \mathrm{mg} / \mathrm{L}$ and $11.2 \mathrm{mg} / \mathrm{L}$ with a range of 4.71 to $18.6 \mathrm{mg} / \mathrm{L}$, respectively. The values of manganese and aluminum averaged $2.18 \mathrm{mg} / \mathrm{L}$ with a range of 0.9 to $3.56 \mathrm{mg} / \mathrm{L}$ and $2.18 \mathrm{mg} / \mathrm{L}$ with a range of 1.60 to $5.90 \mathrm{mg} / \mathrm{L}$, respectively. The chloride in the water collected at BC-8 averaged $1.11 \mathrm{mg} / \mathrm{L}$ with a range of 0.25 to $4.0 \mathrm{mg} / \mathrm{L}$. Values of nitrite collected at BC-8 were found to be consistently below detectable limits. The values of nitrate at $\mathrm{BC}-8$ averaged $0.11 \mathrm{mg} / \mathrm{L}$ with a range of 0.01 to $0.15 \mathrm{mg} / \mathrm{L}$. Values of ammonia and phosphate were found to average $0.05 \mathrm{mg} / \mathrm{L}$ with a range of 0.01 to 0.15 $\mathrm{mg} / \mathrm{L}$ and $0.034 \mathrm{mg} / \mathrm{L}$ with a range of 0.003 to $0.063 \mathrm{mg} / \mathrm{L}$, respectively. 
The flow at BC-8 was low because this site was on a tributary of Beaver Creek. The $\mathrm{pH}$ and conductivity at this site were low and slightly low, respectively. The values of alkalinity were low and the values of acidity were high at BC-8, which means that the water at this site was acidic. The nutrient concentrations at $\mathrm{BC}-8$ were low and the metals concentrations were high.

\subsubsection{Lower Beaver Creek (BC-6 and BC-9)}

The air and water temperature averaged $10.6{ }^{\circ} \mathrm{C}$ with a range of -0.3 to $26.7{ }^{\circ} \mathrm{C}$ and $9.6{ }^{\circ} \mathrm{C}$ with a range of 0.3 to $21.5{ }^{\circ} \mathrm{C}$, respectively. The turbidity and TSS averaged 6.1 NTUs with a range of 1.7 to 21.5 NTUs and $6.90 \mathrm{mg} / \mathrm{L}$ with a range of 2.45 to 23.20 $\mathrm{mg} / \mathrm{L}$, respectively. The stream at BC-6/9 had an average flow rate of $1.447 \mathrm{~m}^{3} / \mathrm{sec}$ with a range of 0.090 to $7.810 \mathrm{~m}^{3} / \mathrm{sec}$. The $\mathrm{pH}$ and conductivity averaged 6.2 with a range of 4.9 to 7.8 and $152.5 \mu \mathrm{S} / \mathrm{cm}$ with a range of 62.6 to $288.3 \mu \mathrm{S} / \mathrm{cm}$, respectively. The alkalinity and acidity averaged $15.98 \mathrm{mg} / \mathrm{L}$ as $\mathrm{CaCO}_{3}$ with a range of 3.68 to $24.12 \mathrm{mg} / \mathrm{L}$ as $\mathrm{CaCO}_{3}$ and $5.43 \mathrm{mg} / \mathrm{L}$ as $\mathrm{CaCO}_{3}$ with a range of 3.16 to $10.0 \mathrm{mg} / \mathrm{L}$ as $\mathrm{CaCO}_{3}$, respectively. The water collected at BC-6/9 averaged $52.1 \mathrm{mg} / \mathrm{L}$ of sulfate with a range of 36.1 to $87.5 \mathrm{mg} / \mathrm{L}$. The average value of iron found at BC-6/9 was $0.65 \mathrm{mg} / \mathrm{L}$ with a range of 0.27 to $1.23 \mathrm{mg} / \mathrm{L}$. The values of calcium and magnesium averaged $16.9 \mathrm{mg} / \mathrm{L}$ with a range of 8.30 to $41.2 \mathrm{mg} / \mathrm{L}$ and $4.23 \mathrm{mg} / \mathrm{L}$ with a range of 0.37 to $8.72 \mathrm{mg} / \mathrm{L}$, respectively. The values of manganese and aluminum averaged $0.75 \mathrm{mg} / \mathrm{L}$ with a range of 0.37 to $3.20 \mathrm{mg} / \mathrm{L}$ and $0.8 \mathrm{mg} / \mathrm{L}$ with a range of 0.2 to $3.5 \mathrm{mg} / \mathrm{L}$, respectively. The chloride in the water collected at BC-6/9 averaged $4.3 \mathrm{mg} / \mathrm{L}$ with a range of 0.30 to 9.7 $\mathrm{mg} / \mathrm{L}$. Values of nitrite collected at BC-6/9 were found to be consistently below 
detectable limits. The values of nitrate at BC-6/9 averaged $0.34 \mathrm{mg} / \mathrm{L}$ with a range of 0.18 to $0.65 \mathrm{mg} / \mathrm{L}$. Values of ammonia and phosphate were found to average $0.58 \mathrm{mg} / \mathrm{L}$ with a range of 0.11 to $1.51 \mathrm{mg} / \mathrm{L}$ and $0.864 \mathrm{mg} / \mathrm{L}$ with a range of 0.005 to $5.080 \mathrm{mg} / \mathrm{L}$, respectively.

The flow at BC-6/9 was high because this site was located near the outlet of Beaver Creek. The $\mathrm{pH}$ values at $\mathrm{BC}-6 / 9$ were high and the conductivity values at $\mathrm{BC}-6 / 9$ were low. The values of alkalinity were low and the values of acidity were low at BC6\&9, which means that the water at this site was well buffered. The nutrient concentrations at BC-9 were high and the metals concentrations at this site were high.

\subsection{Fish and Macroinvertebrate Sampling Results}

The Beaver Creek water quality grab sample sites were also sampled for fish populations and macroinvertebrate populations as an additional tool for the characterization of the waters in the Beaver Creek watershed. Macroinvertebrate data collected from the water quality grab sample sites in Beaver Creek and subsequent index scores are presented in Table 4.3.1. 
Table 4.3.1. Macroinvertebrate Data and Index Scores from Beaver Creek Water Quality Grab Sampling Sites.

SAMPLING SITES

\begin{tabular}{|c|c|c|c|c|c|c|c|c|}
\hline \multirow[b]{2}{*}{ Metrics } & \\
\hline & BC-1 & BC-2 & $\mathrm{BC}-3$ & BC-4 & BC-5 & BC-7 & BC-8 & $\begin{array}{l}\mathrm{BC}- \\
6 / 9\end{array}$ \\
\hline Total_Taxa & 13 & \multirow{2}{*}{$\begin{array}{c}\text { Not } \\
\text { Sampled }\end{array}$} & 9 & 5 & \multirow{2}{*}{$\begin{array}{c}\text { Not } \\
\text { Sampled }\end{array}$} & 3 & \multirow{2}{*}{$\begin{array}{c}\text { Not } \\
\text { Sampled }\end{array}$} & 11 \\
\hline EPT Taxa & 5 & & 2 & 0 & & 0 & & 3 \\
\hline$\%$ EPT & $49.4 \%$ & & $45.3 \%$ & 0 & & 0 & & $46.2 \%$ \\
\hline $\begin{array}{c}\% \\
\text { chironomidae }\end{array}$ & $18.4 \%$ & & $20.8 \%$ & $82.1 \%$ & & $15.6 \%$ & & $33.3 \%$ \\
\hline $\begin{array}{c}\% \text { top } 2 \\
\text { dominant }\end{array}$ & $37.9 \%$ & & $58.5 \%$ & $91.0 \%$ & & $96.9 \%$ & & $67.9 \%$ \\
\hline HBI & 3.93 & & 4.23 & 6.22 & & 9.18 & & 4.9 \\
\hline WVSCI & 69.8 & & 55.6 & 18.2 & & 19.3 & & 52.5 \\
\hline
\end{tabular}

The fish population data that was collected from the Beaver Creek water quality grab sample sites and subsequent index scores are reported in Table 4.3.2.

Table 4.3.2 Fish Data and Index Scores from Beaver Creek Water Quality Grab Sample Sites.

\begin{tabular}{ccccccc}
\hline \multirow{7}{*}{ Metrics } & BC-1 & BC-3 & BC-5 & BC-7 & BC-8 & BC-6/9 \\
\cline { 2 - 7 } & $\mathbf{1 6 5}$ & $\mathbf{1 7 3}$ & $\mathbf{0}$ & $\mathbf{0}$ & $\mathbf{0}$ & $\mathbf{4 9}$ \\
\hline $\begin{array}{c}\text { Total } \\
\text { Abundance }\end{array}$ & 4 & 4 & - & - & - & 9 \\
$\quad \begin{array}{c}\text { Total Taxa } \\
\text { Standing Stock } \\
\quad \text { (kg) } \\
\quad \text { Shannon- }\end{array}$ & $\mathbf{1 . 4 5 6}$ & $\mathbf{1 . 0 6 8}$ & - & - & - & $\mathbf{0 . 5 5 2}$ \\
$\begin{array}{c}\text { Wiener Species } \\
\text { Diversity }\end{array}$ & 1.07 & 1.56 & - & - & - & 1.82 \\
$\begin{array}{c}\text { Index of Well- } \\
\text { Being (IWB) }\end{array}$ & $\mathbf{5 . 6 6}$ & $\mathbf{5 . 7 2}$ & - & - & - & $\mathbf{4 . 9 6}$ \\
$\begin{array}{c}\text { Index of Biotic } \\
\text { Integrity (IBI) }\end{array}$ & 2.63 & 1.79 & - & - & - & 2.35 \\
- Sample data collected just upstream of BC-3. & & &
\end{tabular}




\subsubsection{Upper Beaver Creek (BC-1)}

An assessment of fish population in Beaver Creek at the BC-1 sampling site yielded a total of 165 fishes representing 4 taxa. Creek chub (Semotilus atromaculatus) was the dominant species captured (125 individuals), and comprised $75.8 \%$ of the relative abundance. The observed standing stock for the stream reach sampled was $1.456 \mathrm{~kg}$, and creek chub $(0.599 \mathrm{~kg})$ and one brook trout (Salvelinus fontinalis) $(0.400 \mathrm{~kg})$ contributed the majority of the biomass. The Shannon-Wiener species diversity index was 1.07 , the Index of Well-Being (IWB) was 5.66, and the Index of Biological Integrity (IBI) calculated for this site was 2.63. In addition to fish populations, a total of thirteen taxa of macroinvertebrates were collected from $\mathrm{BC}-1$ grab sample site. Of the thirteen taxa of macroinvertebrates collected from BC-1, five were EPT taxa and $49.4 \%$ of the total abundance were EPT taxa. Following analysis of the macroinvertebrates collected from the BC-1 sampling site a West Virginia Stream Condition Index (WVSCI) score of 69.8 was assigned to that site. The WVSCI score of 69.8 placed the stream at BC-1 in the "good" stream rank or category.

\subsubsection{Gatmer (BC-3)}

The BC-3 sampling site was not sampled for fish populations during the study period, however, a sampling site on the main-stem of Beaver Creek (BC-15) located a few hundred yards upstream of $\mathrm{BC}-3$ was sampled for fish population during the sampling period. Because of the relatively close proximity of BC-15 to BC-3, the fish population data collected from $\mathrm{BC}-15$ was used to characterize the water at $\mathrm{BC}-3$. A total 
of 173 fishes representing four taxa were collected from this site. Creek chub (Semotilus atromaculatus)was the dominant species captured (99 individuals), and comprised 57.2\% of the relative abundance. The observed standing stock for the stream reach was 1.068 $\mathrm{kg}$, and creek chub $(0.495 \mathrm{~kg})$ and white sucker $(0.440 \mathrm{~kg})$ contributed the majority of the biomass. Tolerant taxa included creek chub, white sucker, green sunfish, and blacknose dace (Rhinichthys atratulus). The Shannon-Wiener species diversity index was 1.82 , the Index of Well-Being (IWB) was 5.72, and the Index of Biological Integrity (IBI) score was 1.79. Along with fish population data, macroinvertebrate data was collected at the BC-3 sampling site. During sampling of BC-3 for macroinvertebrates a total of nine taxa were collected. Of the nine taxa collected from BC-3, two taxa were EPT taxa and 45.3 $\%$ of the total abundance were EPT taxa. Following analysis of the macroinvertebrates collected from the BC-3 sampling site a West Virginia Stream Condition Index (WVSCI) score of 55.6 was assigned to that site.

\subsubsection{Iron Pond (BC-4)}

The BC-4 sampling site was not sampled for fish populations during the study period, however the site was sampled for macroinvertebrates. During sampling of BC-4 for macroinvertebrates a total of five taxa were collected. Of the five taxa collected from BC-4, zero were EPT taxa, thus $0 \%$ of the taxa were EPT taxa. Following analysis of the macroinvertebrates collected from the BC-3 sampling site a WVSCI score of 18.2 was assigned to that site. The WVSCI score of 18.2 placed the stream at BC-3 in the "very poor" stream rank or category. 


\subsubsection{Slate Culvert (BC-5)}

The tributary that BC-5 was located on was not sampled for macroinvertebrates, but it was sampled for fish species and population. The 100-m section of the tributary yielded no fish.

\subsubsection{Chaffee (BC-7)}

The tributary on which $\mathrm{BC}-7$ is located was sampled for macroinvertebrate and fish population. The fish sampling of the stream yielded no fish. The sampling of the stream at the $\mathrm{BC}-7$ grab sample site for macroinvertebrates yielded a total of two different taxa. Of the two taxa collected at the $\mathrm{BC}-7$ sampling site, none of the taxa were EPT taxa, thus $0 \%$ of the total abundance were EPT taxa. Upon further analysis of the macroinvertebrate sample collected at $\mathrm{BC}-7$, a WVSCI score of 19.3 was assigned to the stream at BC-7. The WVSCI score of 19.3 placed the stream on which the BC-7 sampling site is located in the "very poor" stream rank or category.

\subsubsection{Hawkins (BC-8)}

The tributary that $\mathrm{BC}-8$ was located on was not sampled for macroinvertebrates, but it was sampled for fish population. The 78.2-meter section of the tributary that was sampled yielded no fish. 


\subsubsection{Lower Beaver Creek (BC-6/9)}

The sampling of the BC-6 water quality grab sample site yielded a total of 49 fishes (9 taxa) from this site. Creek chub (Semotilus atromaculatus) was the dominant species captured (33 individuals), and comprised $67.3 \%$ of the relative abundance. The observed standing stock for the stream reach was $0.552 \mathrm{~kg}$, and creek chub $(0.371 \mathrm{~kg})$ contributed most of the biomass. The sensitivity index indicated that five taxa comprising $83.7 \%$ of the fishes captured at this station were considered pollution tolerant. Three taxa (sand shiner Notropis stramineus, rock bass Ambloplites rupestris, and Johnny darter Etheostoma nigrum) were considered intermediate tolerant, and one species (longnose dace Rhinichthys cataractae) was considered intolerant. Tolerant taxa included bluntnose minnow (Pimephales notatus), creek chub, white sucker, brown bullhead (Ameiurus nebulosus), and green sunfish. The Shannon-Wiener species diversity index was 1.82, the Index of Well-Being (IWB) was 4.96, and the Index of Biological Integrity (IBI) score for this site was 2.35 .

The BC-9 sampling site was also sampled for macroinvertebrates. The sampling trip yielded a total of 11 taxa from the BC-9 site. Of the eleven taxa collected at the BC9 grab sample site, two of the taxa were EPT taxa and $46.2 \%$ of the total abundance was EPT taxa. Upon further analysis of the samples collected from BC-9, a WVSCI score of 52.5 was assigned to Beaver Creek at this site. A WVSCI score of 52.5 at placed the stream at BC-9 in the "fair" rank or category. 


\subsection{DISCUSSION}

During the study period, several surface coal mining operations were actively exhuming coal throughout the Beaver Creek watershed. These operations were permitted and managed according to legislation set forth in SMCRA, including proper water and spoil management and treatment of runoff water. While the water from the active surface mine operations was managed and treated according to SMCRA, the water was still impaired. Nevertheless, the majority of water quality impacts present during this study were likely due to the extensive surface mining operations that took place in the Beaver Creek watershed prior to the enactment of SMCRA. The pre-SMCRA handling techniques used while disposing of acid producing overburden allowed for the creation of AMD throughout the watershed. While several of the abandoned mine lands have been reclaimed or re-mined under current regulations, many of the pre-1977 mines remain as they were left after initial mining.

\subsection{Overall Water Quality}

Average values of water quality parameters from all eight Beaver Creek sampling stations are presented in Table 5.1.1 where the bold face sampling sites are located on the main channel of Beaver Creek and the non-bold face sampling sites were located on tributaries of Beaver Creek. 
Table 5.1.1. Average Water Quality Values from the Beaver Creek Sampling Stations.

\begin{tabular}{|c|c|c|c|c|c|c|c|c|}
\hline \multirow{2}{*}{ Parameter } & \multicolumn{8}{|c|}{ Average Values } \\
\hline & BC-1 & BC-2 & BC-3 & BC-4 & $\mathrm{BC}-5$ & $\mathrm{BC}-7$ & BC-8 & BC-6/9 \\
\hline Air Temperature, ${ }^{\circ} \mathrm{C}$ & 10.2 & 10.1 & 10.3 & 10.7 & 11.6 & 15 & 15.1 & 10.6 \\
\hline Water Temp, ${ }^{\circ} \mathrm{C}$ & 7.4 & 9.3 & 8.3 & 9.8 & 10.3 & 13.9 & 14.5 & 9.6 \\
\hline Turbidity, NTU & 2.94 & 3.10 & 3.01 & 1.84 & 2.00 & 2.70 & 2.20 & 6.10 \\
\hline Flow, $\mathrm{m}^{3} / \mathrm{s}$ & 0.086 & \#\# & 0.678 & 0.001 & 0.003 & 0.074 & 0.071 & 1.447 \\
\hline pH & 5.12 & 6.12 & 6.47 & 4.24 & 2.91 & 3.81 & 4.10 & 6.18 \\
\hline Conductivity, $\mu \mathrm{S} / \mathrm{cm}$ & 59.9 & 333.1 & 143.4 & 286.2 & 734.0 & 304.7 & 260.1 & 152.5 \\
\hline TSS, mg/L & 1.68 & 4.07 & 2.45 & 3.02 & 1.89 & 3.11 & 2.93 & 6.90 \\
\hline Alkalinity, $\mathrm{mg} / \mathrm{L} \mathrm{CaCO}_{3}$ & 12.26 & 19.80 & 21.71 & 10.27 & 0.14 & 5.06 & 6.90 & 15.98 \\
\hline Acidity, mg/L $\mathrm{CaCO}_{3}$ & 12.02 & 19.60 & 14.29 & 34.54 & 129.5 & 56.6 & 41.00 & 5.40 \\
\hline Sulfates, $\mathrm{mg} / \mathrm{L}$ & 10.3 & 131.3 & 43.2 & 120.3 & 207.0 & 101.0 & 102.4 & 52.1 \\
\hline Chloride, mg/L & 6.7 & 3.1 & 3.7 & 2.1 & 2.1 & 0.8 & 1.1 & 4.3 \\
\hline Iron, mg/L & 0.20 & 0.58 & 1.85 & 2.83 & 8.85 & 2.36 & 1.59 & 0.65 \\
\hline Calcium, mg/L & 4.8 & 28.7 & 15.2 & 23.4 & 16.6 & 10.0 & 13.9 & 16.9 \\
\hline Magnesium, mg/L & 0.42 & 8.22 & 3.51 & 8.50 & 19.30 & 9.80 & 11.22 & 4.23 \\
\hline Manganese, mg/L & 0.06 & 1.54 & 0.70 & 3.00 & 5.81 & 3.17 & 2.18 & 0.75 \\
\hline Aluminum, mg/L & 0.90 & 0.14 & 0.30 & 2.70 & 6.90 & 5.10 & 4.00 & 0.60 \\
\hline Nitrite, $\mathrm{mg} / \mathrm{L}$ & 0.01 & 0.02 & 0.05 & 0.01 & 0.01 & 0.01 & 0.01 & 0.01 \\
\hline Nitrate, $\mathrm{mg} / \mathrm{L}$ & 0.04 & 0.38 & 0.35 & 0.01 & 0.05 & 0.05 & 0.1 & 0.29 \\
\hline Ammonia, mg/L & 0.005 & 12.830 & 2.230 & 0.018 & 0.100 & 0.227 & 0.046 & 0.660 \\
\hline Phosphate, mg/L & 0.006 & 0.019 & 0.048 & 0.015 & 0.038 & 0.021 & 0.022 & 0.404 \\
\hline
\end{tabular}

Sampling sites in bold face were located on the main stem and non-bold face were located on tributaries.

\#\# - no flow measured at this site

In order to determine if the changes in water quality parameters were statistically significant, the data collected at the $\mathrm{BC}-1, \mathrm{BC}-3$, and $\mathrm{BC}-6 / 9$ Beaver Creek sampling stations were analyzed using the Paired-t Test method described previously in Section 3.7. The results of the statistical analysis are presented in Table 5.1.2. The statistical 
analysis of several of the parameters failed because the parameters were not normally distributed, which is required to apply the Paired-t Test.

Table 5.1.2. Statistical Analysis Results of BC-1, BC-3, and BC-9 Sampling Station Data.

\begin{tabular}{|c|c|c|c|c|c|c|c|c|c|}
\hline \multirow[b]{2}{*}{ Parameter } & \multicolumn{3}{|c|}{$\mathrm{BC}-1$ to $\mathrm{BC}-3$} & \multicolumn{3}{|c|}{$\mathrm{BC}-3$ to $\mathrm{BC}-6 / 9$} & \multicolumn{3}{|c|}{$\mathrm{BC}-1$ to $\mathrm{BC}-6 / 9$} \\
\hline & $\begin{array}{c}\mathrm{t} \\
\text { value }\end{array}$ & change? & $\uparrow$ or $\downarrow$ & $\begin{array}{c}\mathrm{t} \\
\text { value }\end{array}$ & Change? & $\uparrow$ or $\downarrow$ & $\begin{array}{c}\mathrm{t} \\
\text { value }\end{array}$ & change? & $\uparrow$ ¡r $\downarrow$ \\
\hline Air Temp & -0.57 & NO & & 0.38 & NO & & -0.23 & NO & \\
\hline Water Temp & -1.99 & NO & & -1.15 & NO & & $\dagger$ & $\dagger$ & \\
\hline Turbidity & -2.33 & YES & $\uparrow$ & -2.79 & YES & $\uparrow$ & -5.29 & YES & $\uparrow$ \\
\hline Flow & -4.02 & YES & $\uparrow$ & -4.59 & YES & $\uparrow$ & -4.69 & YES & $\uparrow$ \\
\hline $\mathrm{pH}$ & -7.61 & YES & $\uparrow$ & 1.51 & NO & & -5.49 & YES & $\uparrow$ \\
\hline Conductivity & -7.63 & YES & $\uparrow$ & -0.37 & NO & & -4.81 & YES & $\uparrow$ \\
\hline TSS & -1.21 & NO & & -3.00 & YES & $\uparrow$ & -6.63 & YES & $\uparrow$ \\
\hline Alkalinity & -4.51 & YES & $\uparrow$ & 4.34 & YES & $\downarrow$ & -4.04 & YES & $\uparrow$ \\
\hline Acidity & 6.25 & YES & $\uparrow$ & -5.65 & YES & $\downarrow$ & 2.91 & YES & $\downarrow$ \\
\hline Sulfate & -6.58 & YES & $\uparrow$ & -2.83 & YES & $\uparrow$ & -10.8 & YES & $\uparrow$ \\
\hline Chloride & 2.55 & YES & $\downarrow$ & -0.64 & NO & & 2.38 & YES & $\downarrow$ \\
\hline Iron & -2.60 & YES & $\uparrow$ & 0.31 & NO & & -6.33 & YES & $\uparrow$ \\
\hline Calcium & -3.98 & YES & $\uparrow$ & -2.67 & YES & $\uparrow$ & -6.48 & YES & $\uparrow$ \\
\hline Magnesium & -4.39 & YES & $\uparrow$ & -1.91 & NO & & -6.55 & YES & $\uparrow$ \\
\hline Manganese & -2.84 & YES & $\uparrow$ & -1.42 & NO & & $\dagger$ & $\dagger$ & \\
\hline Aluminum & 2.41 & YES & $\downarrow$ & -2.40 & YES & $\uparrow$ & -2.41 & YES & $\downarrow$ \\
\hline Nitrite & $\dagger$ & $\dagger$ & & $\dagger$ & $\dagger$ & & $\dagger$ & $\dagger$ & \\
\hline Nitrate & -4.43 & YES & $\uparrow$ & 1.87 & NO & & -5.19 & YES & $\uparrow$ \\
\hline Ammonia & -3.66 & YES & $\uparrow$ & 4.11 & YES & $\downarrow$ & $\dagger$ & $\dagger$ & \\
\hline Phosphate & -1.12 & NO & & -0.45 & $\mathrm{NO}$ & & -2.51 & YES & $\uparrow$ \\
\hline
\end{tabular}

Along with the water quality grab sample data, the waters of the Beaver Creek watershed were characterized using macroinvertebrate and fish sampling data from 
each respective water quality sampling site. This added insight was coupled with the water quality grab sample data and the YSI Sonde data to more fully characterize the water at each sampling station.

The degradation of water quality as the water flowed downstream through Beaver Creek was represented in the grab sample data in Table 5.1.1, the statistical analysis in Table 5.1.2, and the biological sampling results. The degradation of Beaver Creek began with inputs of impaired waters below BC-1, which can be verified by the trends observed in the water quality data from $\mathrm{BC}-1$ to $\mathrm{BC}-3$. As the water flowed downstream from $\mathrm{BC}$ 3 to $\mathrm{BC}-6 / 9$, the water quality appeared to remain unchanged from that of $\mathrm{BC}-3$ for the majority of analyzed parameters. The other four sampling sites analyzed in Table 5.1.1, BC-4, BC-5, BC-7, and BC-8, were representative of the tributaries conveying impaired waters that impacted the main channel of Beaver Creek between BC-3 and BC-6/9.

As a result of the statistical analysis presented in Table 5.1.2 and the trends observed in the data presented in Table 5.1.1, a decision was made to analyze and characterize the water quality in Beaver Creek based on two sections or reaches. The main channel of Beaver Creek was broken into two sections, above and below the Gatzmer sampling site (BC-3). The section of Beaver Creek from BC-1 to BC-3 represented a less impacted and potentially reclaimable reach of stream, while the lower section of Beaver Creek (BC-3 to BC-6/9) represented an AMD impacted reach of stream which was in need of remediation, though full restoration is unlikely. 


\subsection{Above Gatzmer}

\subsubsection{Water Quality}

The average $\mathrm{pH}$ from the grab sample data, $\mathrm{pH} 5.12$ (4.50-6.10), at the BC-1 sampling site was lower than the minimum limit for aquatic life, $\mathrm{pH} 6.5$, presented in Table 4.2.1. Additionally, the average aluminum value was in excess of the maximum value for the support of aquatic life at the BC-1 grab sample site. The major water quality-related concern at $\mathrm{BC}-1$ was the inability of the water to buffer against changes in $\mathrm{pH}$ which is illustrated by the low and approximately equal values of alkalinity and acidity, which represented approximately no net alkalinity. The inability of the water to buffer against changes in $\mathrm{pH}$ at $\mathrm{BC}-1$ was also evident in the $\mathrm{pH}$ data collected by the YSI Sondes at BC-1. Data representing the $\mathrm{pH}$ as collected by the YSI Sondes at BC-1 is presented in Figure 5.2.1.

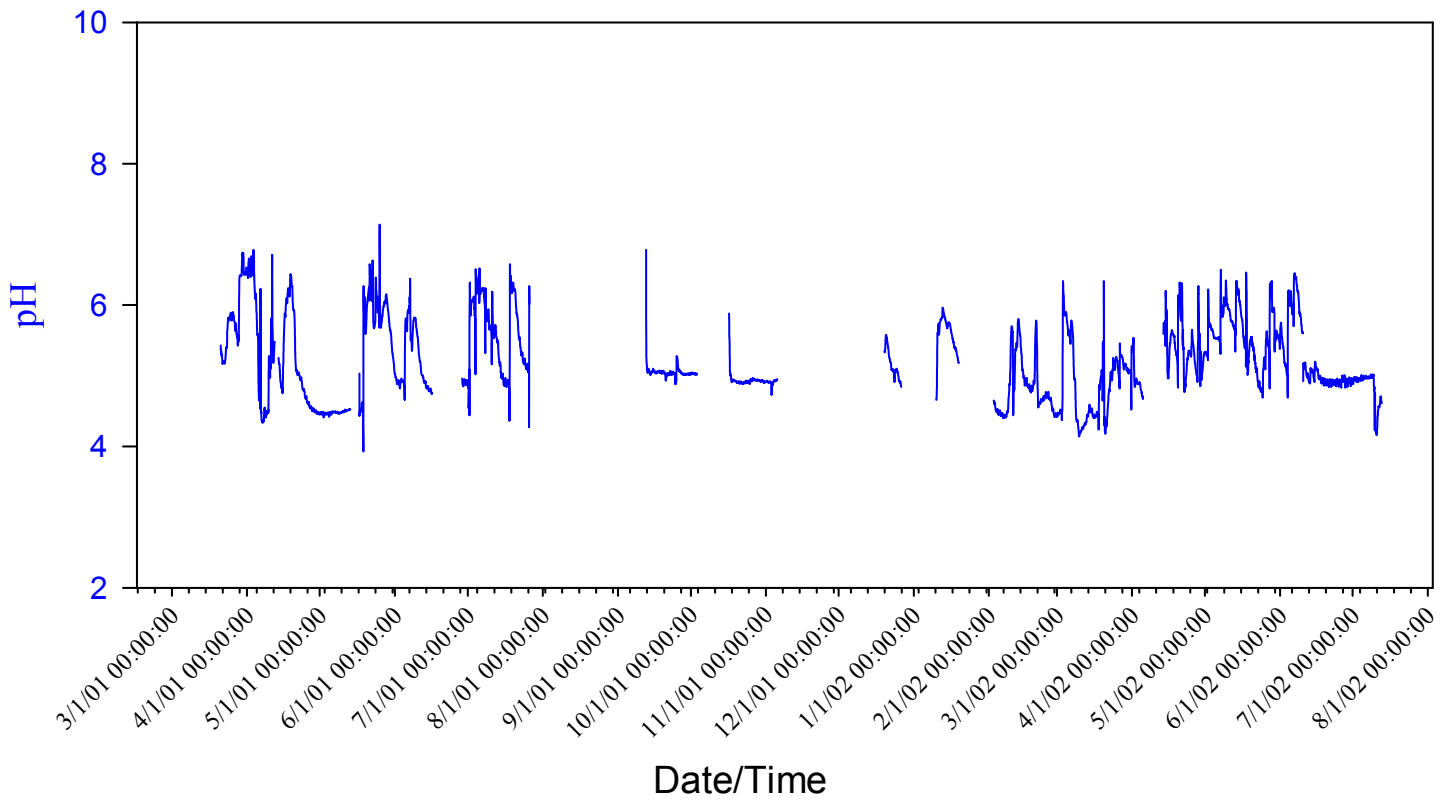

Figure 5.2.1. pH Data Collected by the YSI Sondes from the BC-1. 
The fluctuating behavior exhibited by the $\mathrm{pH}$ data in Figure 5.2.1 is representative of water that is unable to buffer against changes in $\mathrm{pH}$. The inability of water to change the $\mathrm{pH}$ is indicative of water with a low buffer capacity (Snoeyink and Jenkins, 1980; Stumm and Morgan, 1996).

Using the fish and macro-invertebrate data collected from the BC-1 grab sample site, several index scores were calculated which characterized the stream based on a numeric scale. Based on the fish-indices, the BC-1 sampling site was characterized as poor. Of the fish species collected at the $\mathrm{BC}-1$ grab sample site, the most notable was a brook trout (Salvelinus fontinalis). BC-1 was the only grab sample site found to contain a brook trout throughout the Beaver Creek watershed. From the macro-invertebrate data the WVSCI score (69.8) for the stream at BC-1 indicated a "good" stream condition.

The water quality at $\mathrm{BC}-2$ was characterized as having a low average $\mathrm{pH}$ and high concentrations of manganese and aluminum, with respect to the limits for the support of aquatic life. Although not in excess of the limits set forth in Table 4.2.1, the average iron, sulfate, magnesium, and conductivity concentrations were elevated as compared to the values observed at $\mathrm{BC}-1$. Higher metal concentrations were indicative of a change in land use from the minimally impacted site at Upper Beaver Creek to a locale impacted by current and historic mining activities. Average values for nitrite, nitrate, ammonia, and phosphate also increased from the values recorded at $\mathrm{BC}-1$. The increase in nutrient concentrations, most notably the concentration of nitrogen species, observed between BC-1 and BC-2 were representative of characteristic water quality trends of wetlands. (Mitsch and Gosselink, 2000) Furthermore, Stephens (2003) reported that a portion of Elder Swamp was covered by an Alder thicket, which is a nitrogen fixing plant and is 
expected in wetlands with high nitrogen concentrations. This being said, the elevated concentrations of nitrogen recorded at the $\mathrm{BC}-2$ sampling site were mostly due to the active treatment of AMD waters via the addition of anhydrous ammonia. The treated AMD water entered Beaver Creek by the tributary that converged with the main stem of Beaver Creek at the BC-2 sampling site. The average alkalinity and acidity values remained approximately equal, which indicated that the water at $\mathrm{BC}-2$ was also poorly buffered against changes in $\mathrm{pH}$.

\subsubsection{Remediation Recommendations}

Based on the assessment of water quality data, and historic and current land use practices, an opportunity to restore the headwaters of Beaver Creek to suitable brook trout fishery was identified. Water chemistry criteria for the support of salmonids, (Meade 1989), are presented along with the average values from the BC-1 grab sample site in Table 5.2.2.1.

Table 5.2.2.1. Water Chemistry Criteria for the Support of Salmonids and the Average Values Recorded from BC-1 Sampling Site.

\begin{tabular}{|c|c|c|}
\hline Parameter & $\begin{array}{c}\text { Criteria, (Meade } \\
\text { 1989) }\end{array}$ & $\begin{array}{c}\text { Average Value from } \\
\text { BC-1 }\end{array}$ \\
\hline $\begin{array}{c}\text { Dissolved Oxygen } \\
\text { pH }\end{array}$ & $\begin{array}{c}5 \mathrm{mg} / \mathrm{L} \text {-saturation } \\
6.5-8.0\end{array}$ & $\begin{array}{l}9.67 \mathrm{mg} / \mathrm{L}^{\dagger} \\
5.12\end{array}$ \\
\hline Alkalinity $\left(\right.$ as $\left.\mathrm{CaCO}_{3}\right)$ & $10-400 \mathrm{mg} / \mathrm{L}$ & $12.26 \mathrm{mg} / \mathrm{L}$ as $\mathrm{CaCO}_{3}$ \\
\hline Total Hardness (as $\mathrm{CaCO}_{3}$ ) & $10-400 \mathrm{mg} / \mathrm{L}$ & $6.38 \mathrm{mg} / \mathrm{L}$ \\
\hline Sulfate & $<50 \mathrm{mg} / \mathrm{L}$ & $10.3 \mathrm{mg} / \mathrm{L}$ \\
\hline Total Iron & $0.1 \mathrm{mg} / \mathrm{L}$ & $0.2 \mathrm{mg} / \mathrm{L}$ \\
\hline Aluminum & $<0.01 \mathrm{mg} / \mathrm{L}$ & $0.9 \mathrm{mg} / \mathrm{L}$ \\
\hline Manganese & $<0.01 \mathrm{mg} / \mathrm{L}$ & $0.06 \mathrm{mg} / \mathrm{L}$ \\
\hline Calcium & $4-160 \mathrm{mg} / \mathrm{L}$ & $4.8 \mathrm{mg} / \mathrm{L}$ \\
\hline Magnesium & $<15 \mathrm{mg} / \mathrm{L}$ & $0.42 \mathrm{mg} / \mathrm{L}$ \\
\hline
\end{tabular}

${ }^{\dagger}$ Data collected by YSI Sondes 
Alkaline additions were recommended to increase the ability of the water to buffer against changes in $\mathrm{pH}$ at $\mathrm{BC}-1$ and also reduce the dissolved metal concentrations in the water at BC-1 (Snoeyink and Jenkins, 1980; Stumm and Morgan, 1996). Subsequently the alkaline additions would increase the total hardness of the water at BC1. The increase in $\mathrm{pH}$ and decrease in dissolved metal concentrations would then bring all measured water quality parameters within the criteria set forth by Meade (1989) and facilitate the reestablishment of a brook trout fishery at BC-1. The presence of brook trout in the vicinity of Upper Beaver Creek validates the goal of reestablishing a brook trout fishery in the headwaters of Beaver Creek.

The presence of brook trout in the headwaters of Beaver Creek was impossible according to the standards for the support of salmonids, Meade (1989). Recognizing that the concentration of sulfate at $\mathrm{BC}-1$ was high, the complexation of metal ions with inorganic ligands (such as $\mathrm{SO}_{4}{ }^{2-}$ ) could explain the survival of the brook trout. Through the complexation of metal ions, properties that depend on free metal ion concentration, such as solubility, toxicity, and biostimulatory properties, are altered (Snoeyink and Jenkins, 1980). Chemical Equilibria in Aquatic Systems (ChEAqS), a chemical equilibrium modeling program (Verweij, 2002) was utilized to determine the approximate speciation and concentration of metal ions in the water at BC-1. The results from $\mathrm{ChEAqS}$, using the average water quality parameter values collected from $\mathrm{BC}-1$ (Table 5.2.2.1), are presented in Table 5.2.2.2. 
Table 5.2.2.2. Speciation and Percent Abundance of Metal Ion and Inorganic Ligand Complexes at BC-1, as Calculated by ChEAqS.

\begin{tabular}{|c|c|c|c|c|c|}
\hline Ion & Speciation & Percent & Ion & Speciation & Percent \\
\hline \multirow{8}{*}{ Al } & $\mathrm{Al}^{3+}$ & 0.04 & \multirow{4}{*}{ Mn } & $\mathrm{Mn}^{2+}$ & 1.23 \\
\hline & $\mathrm{Al}(\mathrm{OH})^{2+}$ & 0.03 & & $\mathrm{Mn}\left(\mathrm{SO}_{4}\right)$ & 98.41 \\
\hline & $\mathrm{Al}(\mathrm{OH})_{2}^{+}$ & 0.03 & & $\mathrm{MnCl}^{+}$ & 0.36 \\
\hline & $\mathrm{Al}\left(\mathrm{PO}_{4}\right)^{+}$ & 1.78 & & Total & 100 \\
\hline & $\mathrm{Al}_{2}\left(\mathrm{PO}_{4}\right)(\mathrm{OH})^{2+}$ & 0.01 & \multirow{9}{*}{$\mathrm{Fe}$} & & \\
\hline & $\mathrm{Al}_{2}\left(\mathrm{PO}_{4}\right)(\mathrm{OH})_{2}^{+}$ & 0.06 & & $\mathrm{Fe}^{3+}$ & 0.00 \\
\hline & $\mathrm{Al}\left(\mathrm{SO}_{4}\right)^{+}$ & 98.05 & & $\mathrm{Fe}(\mathrm{OH})_{2}^{+}$ & 0.20 \\
\hline & \multirow[t]{2}{*}{ Total } & \multirow[t]{2}{*}{100} & & $\mathrm{Fe}(\mathrm{OH})_{2}^{+}$ & 82.34 \\
\hline \multirow{5}{*}{ Mg } & & & & $\mathrm{Fe}(\mathrm{OH})_{3}$ & 0.41 \\
\hline & $\mathrm{Mg}^{2+}$ & 1.19 & & $\mathrm{FeH}\left(\mathrm{PO}_{4}\right)^{+}$ & 0.01 \\
\hline & $\mathrm{Mg}\left(\mathrm{SO}_{4}\right)$ & 97.95 & & $\mathrm{Fe}\left(\mathrm{SO}_{4}\right)^{+}$ & 1.24 \\
\hline & $\mathrm{MgCl}^{+}$ & 0.86 & & $\mathrm{Fe}\left(\mathrm{SO}_{4}\right)_{2}^{-}$ & 15.80 \\
\hline & Total & 100 & & Total & 100 \\
\hline
\end{tabular}

Therefore, the free concentrations of metal ions in the headwaters of Beaver Creek were greatly reduced through metal-ligand complexation prior to any treatment.

The costs of treating AMD via active treatment systems has become an increasingly large component of the total cost of mining and reclamation in many Appalachian coal producing areas (Skousen et al., 1996). The cost associated with active AMD treatment systems is related to initial installation and subsequent continuous cost of the chemical reagent addition (Skousen et al., 1996). Furthermore, the quality of the water at $\mathrm{BC}-1$ was considerably less impacted by AMD than the waters normally treated with active treatment systems. Therefore, the continuous, active addition of reagents to the headwaters of Beaver Creek was not likely to be a feasible long term solution based economics. As an alternative to an active treatment facility at $\mathrm{BC}-1$, the passive 
treatment method of limestone sand addition to the headwaters of Beaver Creek and its tributaries was recommended.

As described previously in Section 2.3.5, the amount of limestone sands that should be added to streams is based on the annual average acid load. By multiplying the annual average flow by the annual average acidity of the stream, the annual average acid load can be calculated. The annual average acid load calculated for BC-1 is presented in Table 5.2.2.3.

Table 5.2.2.3. Average Values of Flow and Acidity Used to Calculate the Average Annual Acid Load at BC-1.

\begin{tabular}{ccc|ccc|c}
\hline \multicolumn{3}{c|}{ Flow } & \multicolumn{3}{c|}{ Acidity as $\mathrm{CaCO}_{3}$} & Acid Load \\
\hline $\mathrm{m}^{3} / \mathrm{s}$ & $\mathrm{L} / \mathrm{min}$ & $\mathrm{L} / \mathrm{yr}$ & $\mathrm{mg} / \mathrm{L}$ & $\mathrm{Kg} / \mathrm{L}$ & tons/L & tons/yr as CaCO \\
\hline \hline 0.086 & 5160 & $1.1 \mathrm{E}+08$ & 12.02 & $1.2 \mathrm{E}-05$ & $1.3 \mathrm{E}-08$ & $\mathbf{1 . 5}$
\end{tabular}

Based on the average flow and acidity data collected from $\mathrm{BC}-1$, the average annual acid load is 1.5 tons per year as $\mathrm{CaCO}_{3}$. Therefore, approximately 6.0 tons of limestone sands (4 times 1.5 tons/yr as $\mathrm{CaCO}_{3}$ acid load) should be added to $\mathrm{BC}-1$ per year, as BC-1 is considered a non-AMD impacted stream. Upon considering the size and volume conveyed by the streams that the WVDEP considered non-AMD impacted streams, the realization was made that BC-1 was much smaller and conveyed less volume than the non-AMD impacted streams which were treated by the WVDEP. Therefore, the calculated amount of limestone sand to be added to BC-1 may be an over estimate. Alternate methods of limestone sand treatment dose calculation could be explored. As described by the WVDEP, the limestone sands should be added monthly for the first year and quarterly for two subsequent years.

In order to maximize the restoration benefit which is possible from such an investment in alkalinity addition, the involvement of multiple stakeholders will be 
crucial. The involvement of the WV Department of Natural Resources is vital for the stocking of the headwaters of Beaver Creek with native brook trout. Further, the continual treatment of the headwaters of Beaver Creek with limestone sands has to rely on the involvement of the WV Department of Environmental Protection. Other agencies and groups that will be vital in the protection, monitoring, and further study of the Upper Beaver Creek site may include the West Virginia Division of Highways, local watershed groups, and non-government organizations such as the Canaan Valley Institute.

It is recommended that the treatment of the water at the treatment of the BC-2 site utilize the residual alkalinity from that added at $\mathrm{BC}-1$. The close proximity of $\mathrm{BC}-2$ to BC-1 and the lack of severely impacted water inputs between $\mathrm{BC}-1$ and $\mathrm{BC}-2$ produced the conclusion that the added alkalinity, in the form of $\mathrm{CaCO}_{3}$, and the increased $\mathrm{pH}$ from the treatment of $\mathrm{BC}-1$ will serve to treat the water at $\mathrm{BC}-2$.

\subsection{Upper Beaver Creek to Gatzmer}

The BC-3 site was below an active mine water treatment site as well as downstream from the location where WVDEP dosed the main channel of Beaver Creek with limestone sand once. The mine water treatment facility located near BC-3 utilized anhydrous ammonia to treat AMD impacted water before discharge into Beaver Creek just upstream of BC-3. The anhydrous ammonia treatment facility that discharged to the BC-3 sampling site was not the same treatment facility referred to in the discussion of the BC-2 sampling site. Evidence of the addition of anhydrous ammonia was present in the water quality grab sample data as elevated nitrogen concentrations. As might be expected of a stream directly below an active mine water treatment facility and a 
limestone dosing station, Beaver Creek, at BC-3, was net alkaline and the average $\mathrm{pH}$ of the water was at its highest $(\mathrm{pH}=6.47)$. Likewise, the $\mathrm{BC}-3$ sampling site was the only site in the study to have an average $\mathrm{pH}$ within the range of values for the support of aquatic life, as provided in Table 4.2.1. The elevated alkalinity of the water at BC-3 indicated a capacity of Beaver Creek at BC-3 to buffer against changes in $\mathrm{pH}$. The increased buffering ability of the water at $\mathrm{BC}-3$ was evident when the $\mathrm{pH}$ data collected by the YSI Sondes at BC-3 were compared to the data collected at $\mathrm{BC}-1$, which was determined to be poorly buffered. The $\mathrm{pH}$ data collected by the YSI Sondes at BC-1 and BC-3 are presented in Figure 5.3.1.

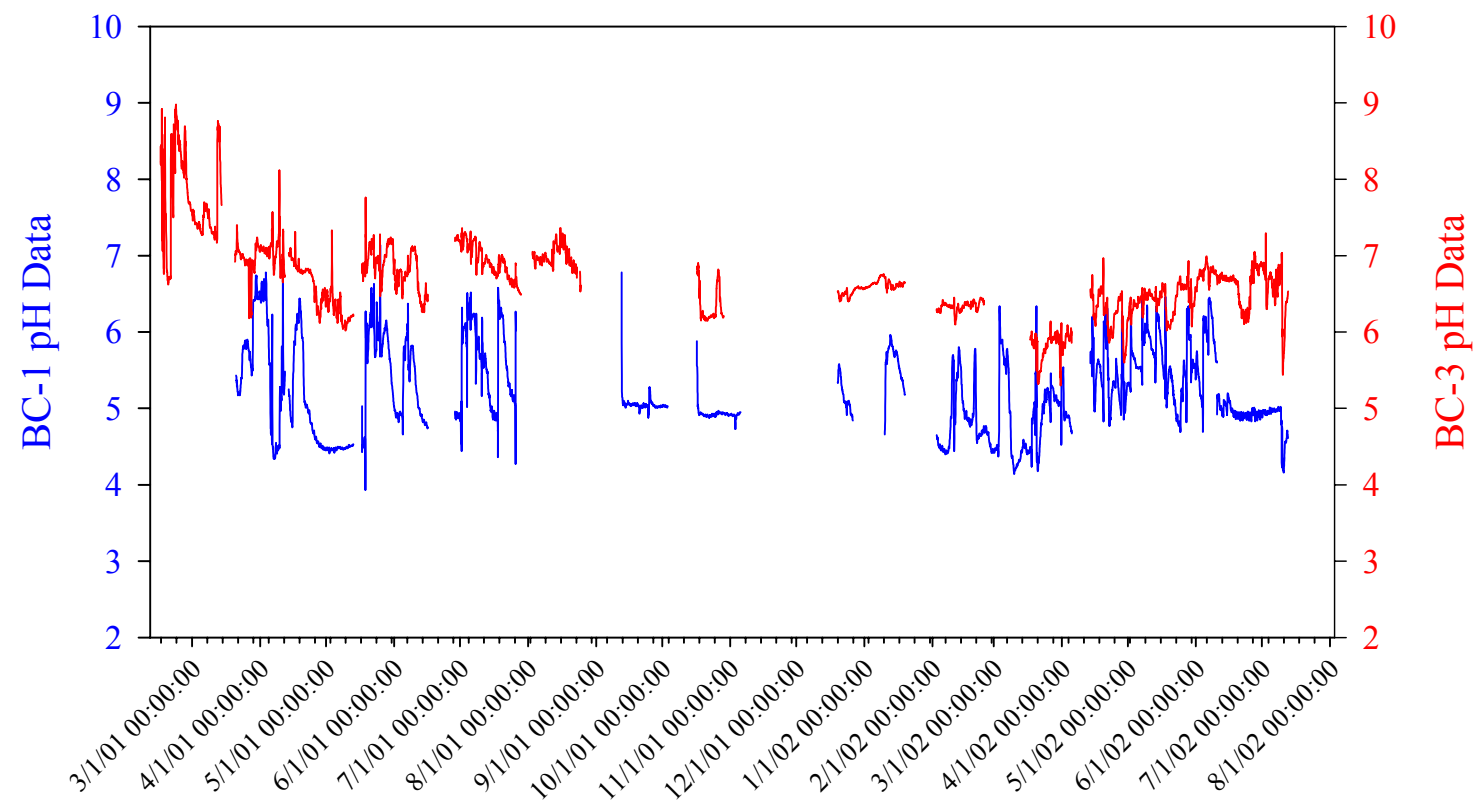

Date/Time

Figure 5.3.1. Comparison of pH Data Collected at BC-1 and BC-3 by the YSI Sondes.

During the study period, the YSI Sonde $\mathrm{pH}$ data collected at BC-3 traversed a wider range (3.68 $\mathrm{pH}$ units) than the $\mathrm{pH}$ data collected from $\mathrm{BC}-1$ (3.21 $\mathrm{pH}$ units), which might generate the conclusion that $\mathrm{BC}-3$ is just as poorly buffered as $\mathrm{BC}-1$, if not worse. 
Conversely, upon visual inspection the $\mathrm{BC}-1 \mathrm{pH}$ data had more "frequent fluctuations" than the $\mathrm{BC}-3 \mathrm{pH}$ data, which indicated that $\mathrm{BC}-3$ was better buffered against $\mathrm{pH}$ changes than the $\mathrm{BC}-1$ sampling site. The greater overall range of the $\mathrm{pH}$ data collected at the BC-3 sampling site could be explained by the treatment of the $\mathrm{BC}-3$ site via limestone dosing by the WVDEP. The addition of the limestone sands would drive the $\mathrm{pH}$ of the water up at the BC-3 sampling site at the time of the dosing, while after an extended period of time the affects of the limestone sands would diminish producing a decrease in the $\mathrm{pH}$ of the water over time. The input of alkalinity from the anhydrous ammonia treatment facility near $\mathrm{BC}-3$ would have also affected the $\mathrm{pH}$ measured at the BC-3 sampling site.

While the average $\mathrm{pH}$ value from the $\mathrm{BC}-3$ grab sample site was within the standards for the support of aquatic life, the average concentrations of iron and aluminum were in excess of the limits for the support of aquatic life. The average concentrations of sulfate, calcium, magnesium, and manganese were elevated, as compared to the values collected from BC-1; however these values did not exceed the limits for the support of aquatic life. The increase of dissolved metals concentrations witnessed from BC-1 to BC-3 was reflected by the increase in the grab sample conductivity data and the increase in specific conductance data collected by the YSI Sondes between BC-1 and BC-3.

Conductance is a measure of the ability of the solution to transmit current, therefore since current is transported through the movement of ions in solution, conductivity increases as ion concentration increases (Snoeyink and Jenkins 1980). Russell (1976) derived a relationship between specific conductance and ionic strength, which is presented in Equation 5.3.1 (Snoeyink and Jenkins 1980). Equation 5.3.1 is an 
approximation of ionic strength, and is often utilized for complex solutions (Snoeyink and Jenkins 1980).

$$
\mu_{\text {meas }}=1.6 \times 10-5 \times \text { specific conductance }(\mu \mathrm{S} / \mathrm{cm})
$$

where $\mu_{\text {meas }}=$ measured ionic strength.

Equation 5.3.2, Lewis and Randall (1921), is used to calculate ionic strength based on an analysis of individual ion concentrations present in the solution (Snoeyink and Jenkins 1980). Values of ionic strength were calculated for the BC-1 and BC-3 grab sample sites with both Equation 5.3.1 and Equation 5.3.2 for comparison. The average values of specific conductance from the YSI Sonde data and the average dissolved metal ion concentrations from the grab sample data were used for the calculations.

$$
\mu_{\text {calc }}=\frac{1}{2} \sum_{i} C_{i} Z_{i}^{2}
$$

where $\mu_{\text {calc }}=$ calculated ionic strength (specific).

$$
\begin{aligned}
& C_{i}=\text { molar concentration of specific ions }(\mathrm{mol} / \mathrm{L}) . \\
& Z_{i}=\text { charge of each ion. }
\end{aligned}
$$

For the $\mathrm{BC}-1$ and $\mathrm{BC}-3$ grab sample sites, the measured molar concentrations of the ions used to determine $\mu_{\text {calc }}$ are presented in Table 5.3.1.

Table 5.3.1. Average Molar Concentrations of Ions Used to Calculate $\mu_{\text {calc }}$.

\begin{tabular}{ccccccccc} 
& {$\left[\mathrm{Fe}^{3+}\right]$} & {$\left[\mathrm{Mn}^{2+}\right]$} & {$\left[\mathrm{Ca}^{2+}\right]$} & {$\left[\mathrm{Mg}^{2+}\right]$} & {$\left[\mathrm{Al}^{3+}\right]$} & {$\left[\mathrm{H}^{+}\right]$} & {$\left[\mathrm{OH}^{-}\right]$} & {$\left[\mathrm{SO}_{4}{ }^{2-}\right]$} \\
\hline BC-1 & $3.58 \times 10^{-6}$ & $1.09 \times 10^{-6}$ & $1.2 \times 10^{-4}$ & $1.73 \times 10^{-5}$ & $3.34 \times 10^{-5}$ & $10^{-5.1}$ & $10^{-8.9}$ & $1.07 \times 10^{-4}$ \\
BC-3 & $3.31 \times 10^{-5}$ & $1.27 \times 10^{-5}$ & $3.79 \times 10^{-4}$ & $1.44 \times 10^{-4}$ & $1.11 \times 10^{-5}$ & $10^{-6.5}$ & $10^{-7.5}$ & $4.5 \times 10^{-4}$
\end{tabular}

Values of $\mu_{\text {meas }}$ and $\mu_{\text {calc }}$ were calculated for the BC-1 and BC-3 sampling sites using 44 $\mu \mathrm{S} / \mathrm{cm}$ and $133 \mu \mathrm{S} / \mathrm{cm}$ as the average specific conductance for the BC-1 and BC-3 grab sample sites, respectively, and the molar concentrations presented in Table 5.3.1. The 
calculated values of $\mu_{\text {meas }}$ and $\mu_{\text {calc }}$ for the $\mathrm{BC}-1$ and $\mathrm{BC}-3$ grab sample sites are presented in Table 5.3.2 along with the percent difference. Equation 5.3.3 was used to determine the percent difference between the measured and calculated values of ionic strength for the BC-1 and BC-3 sampling sites.

$\%$ difference $=\left|\frac{\mu_{\text {calc }}-\mu_{\text {meas }}}{\mu_{\text {calc }}}\right| \times 100$

Table 5.3.2. Values of $\mu_{\text {meas }}$ and $\mu_{\text {calc }}$ and Percent Difference for the BC-1 and BC-3 Grab Sample Sites.

\begin{tabular}{ccc}
\hline & BC-1 & BC-3 \\
\hline \hline$\mu_{\text {meas }}$ & 0.00070 & 0.00213 \\
$\mu_{\text {calc }}$ & 0.00066 & 0.00217 \\
$\%$ diff. & 6.5 & 2 \\
\hline
\end{tabular}

Therefore all major sources of ionic strength were taken into account. The relationship between specific conductance and dissolved metal ions at the $\mathrm{BC}-1$ and $\mathrm{BC} 3$ sampling sites was assumed to hold true for other sampling sites in the Beaver Creek watershed for this study.

A comparison of specific conductance data as collected between BC-1 and BC-3 is represented in Figure 5.3.2. 


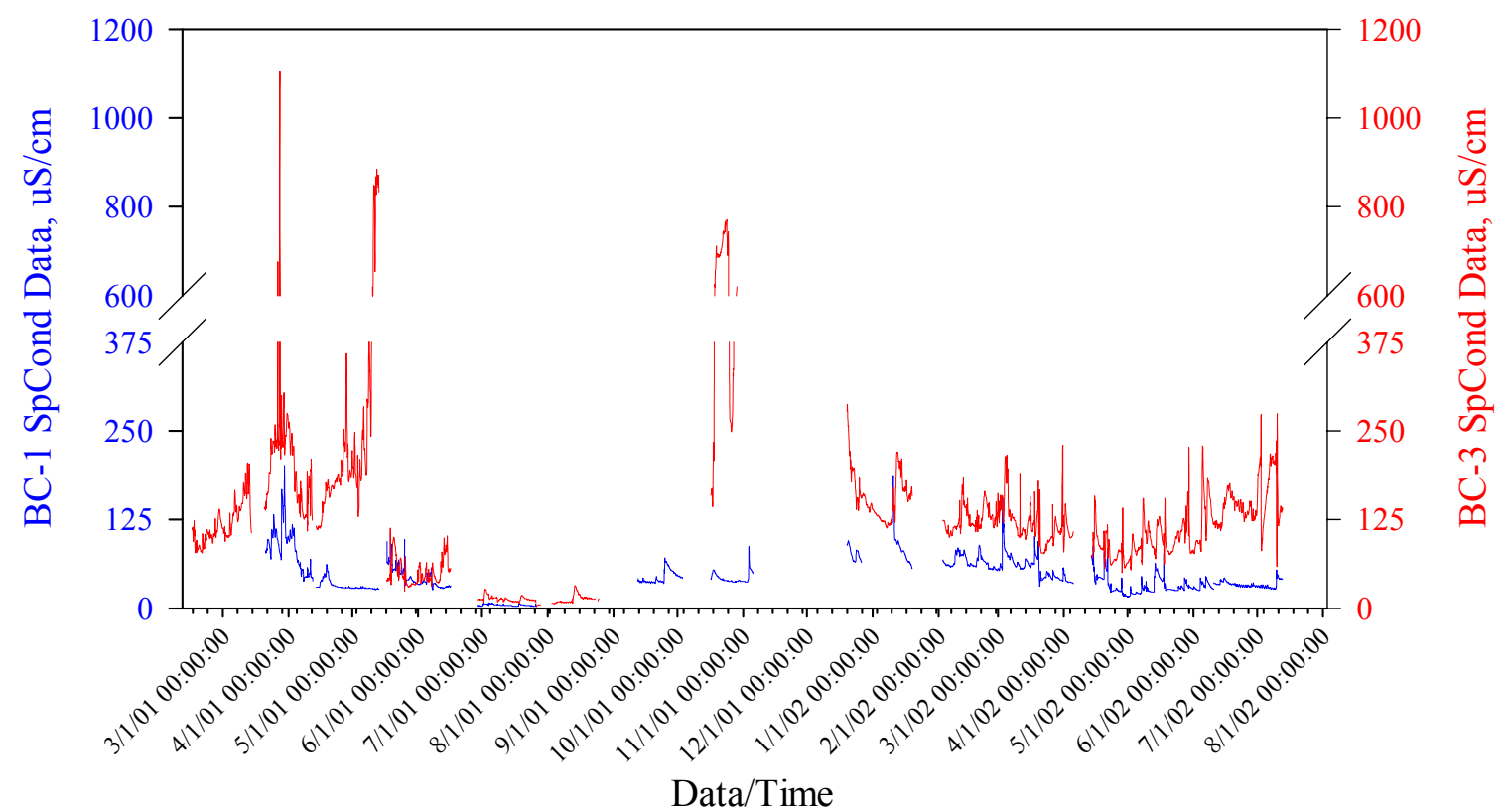

Figure 5.3.2. Comparison of Specific Conductance Data Collected by the YSI Sondes Between BC-1 and BC-3.

The increase in dissolved ion concentrations (principally $\mathrm{Fe}^{3+}, \mathrm{SO}_{4}^{2-}, \mathrm{Al}^{3+}, \mathrm{Mn}^{2+}$ ) in Beaver Creek between $\mathrm{BC}-1$ and $\mathrm{BC}-3$ is represented in the specific conductance data collected by the YSI Sondes and presented in Figure 5.3.2, and the conductivity data collected as part of the grab sample data.

\subsection{Below Gatzmer}

\subsubsection{Main Stem Sites}

The water chemistry at the Lower Beaver/Davis sampling station (BC-6/9) represented the water quality of Beaver Creek just prior to discharge into the Blackwater River. The water quality at $\mathrm{BC}-6 / 9$ also represented the cumulative impact of all the acid drainage inputs that flowed into Beaver Creek from the headwaters at $\mathrm{BC}-1$ to the outlet at BC-6/9. 
At $\mathrm{BC}-6 / 9$ the average $\mathrm{pH}$ was below the limits for the support of aquatic life and the aluminum values exceeded the limits for the support of aquatic life. From the average alkalinity and acidity values measured at the BC-6/9 sampling site, it was determined that the water was net alkaline (alkalinity of $15.98 \mathrm{mg} / \mathrm{L}$ as $\mathrm{CaCO}_{3}$ and acidity of $5.40 \mathrm{mg} / \mathrm{L}$ as $\mathrm{CaCO}_{3}$ ) but still poorly buffered. A comparison of $\mathrm{pH}$ data collected by the YSI Sondes at BC-3 and BC-6/9 is presented in Figure 5.4.1.1.

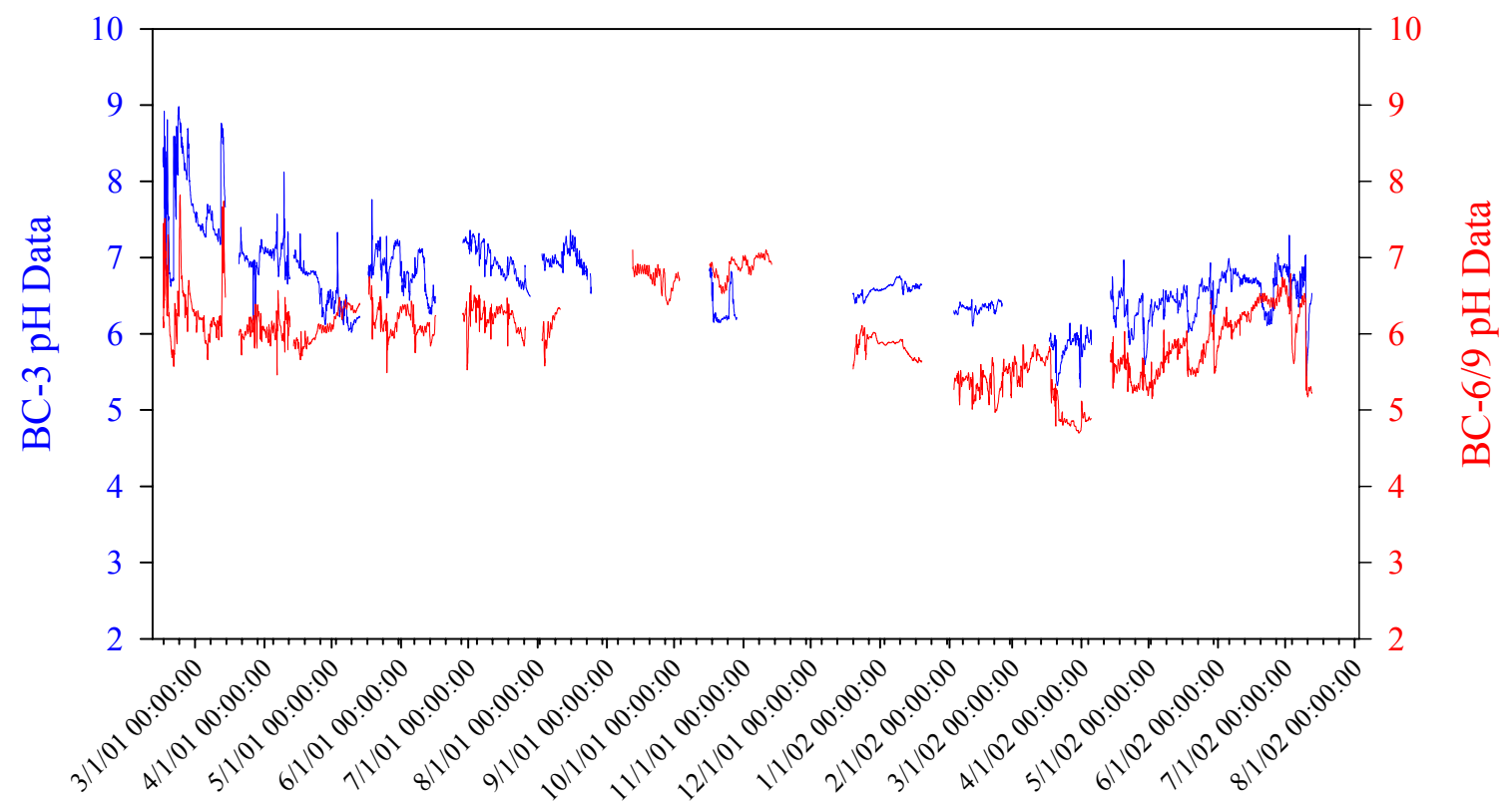

Date/Time

Figure 5.4.1.1. A Comparison of pH Data Collected by the YSI Sondes at $\mathrm{BC}-3$ and $\mathrm{BC}-6 / 9$.

Upon visual inspection, a slight decrease in $\mathrm{pH}$ from $\mathrm{BC}-3$ to $\mathrm{BC}-6 / 9$ was represented in the $\mathrm{pH}$ data collected by the YSI Sondes. The similarity of the $\mathrm{pH}$ data collected by the YSI Sondes is supported by the statistical analysis of grab sample data collected between BC-3 and BC-6/9, presented previously in Table 5.1.2. Likewise, the average specific conductance value also did not change significantly between the BC-3 and BC-6/9 
sampling sites. A comparison of specific conductance data collected by the YSI Sondes at BC-3 and BC-6/9 is presented in Figure 5.4.1.2.

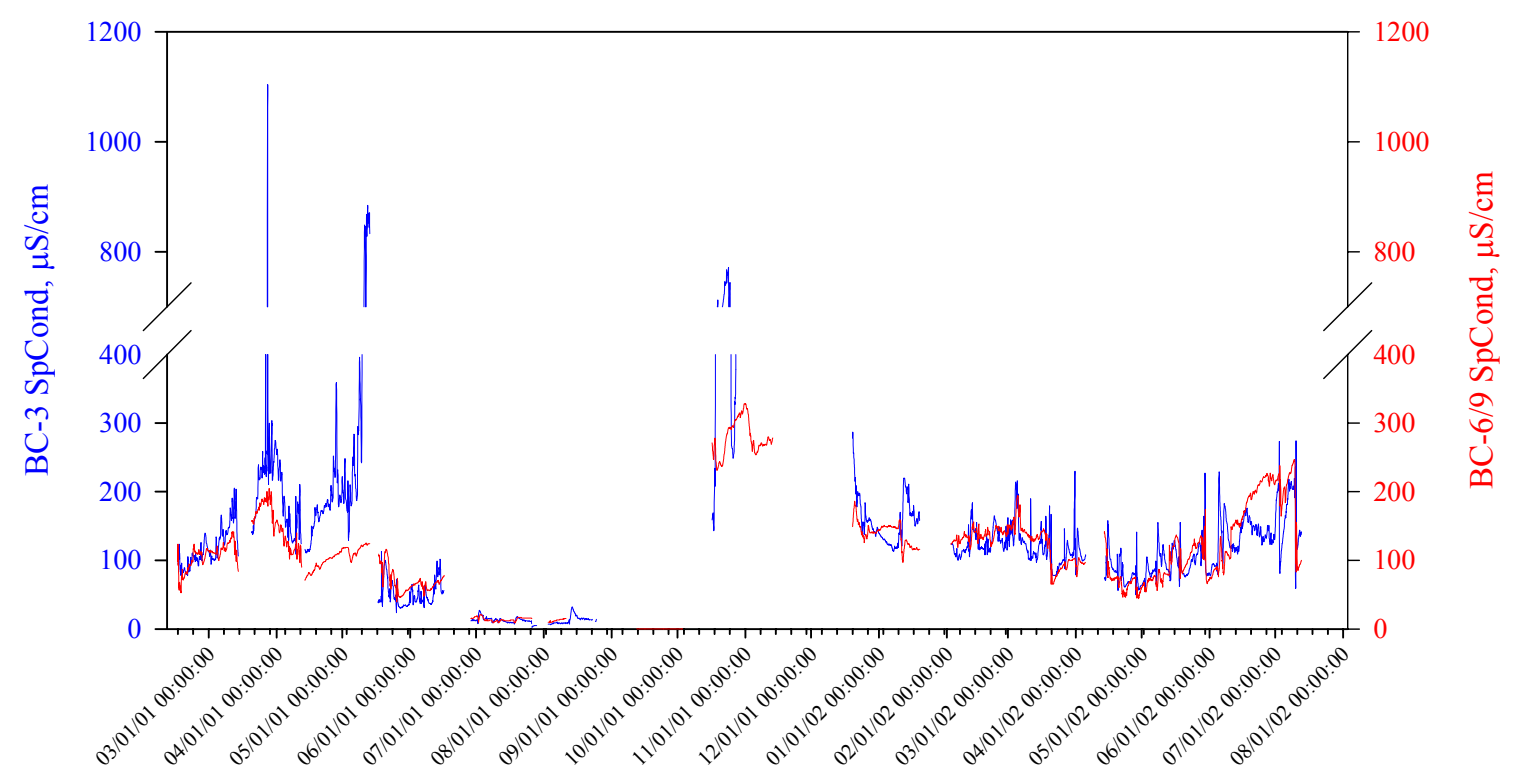

Date and Time

Figure 5.4.1.2. Comparison of Specific Conductance Data Collected by the YSI Sondes at BC-3 and BC-6/9.

The similarity of the specific conductance data collected at BC-3 and BC-6/9 was supported by the conductivity and metal ion concentrations collected for the two sites. From the statistical analysis presented in Table 5.1.2 the lack of change in conductivity and metal ion concentration between $\mathrm{BC}-3$ and $\mathrm{BC}-6 / 9$ is clear.

A dilution process was determined to be the cause of the lack of anticipated degradation of water quality data collected from $\mathrm{BC}-3$ and $\mathrm{BC}-6 / 9$. The dilution effect is illustrated in the average flow rate measurements recorded from the grab sample sites located on the lower reach of Beaver Creek (BC-3, BC-4, BC-5, BC-7, BC-8, and BC6/9), which are presented in Table 5.4.1.1. 
Table 5.4.1.1. Average Flow rate Measurements from the $\mathrm{BC}-3$, BC-4, BC-5, BC-7, BC-8, and BC-6/9 Grab Sample Sites.

\begin{tabular}{ccccccc}
\hline & \multicolumn{4}{c}{ Tributaries } & \multicolumn{3}{c}{ Main Stem } \\
\cline { 2 - 7 } & BC-4 & BC-5 & BC-7 & BC-8 & BC-3 & BC-6/9 \\
\hline \hline $\mathbf{m}^{\mathbf{3}} / \mathbf{s}$ & 0.001 & 0.003 & 0.071 & 0.074 & 0.678 & 1.447 \\
$\mathbf{L} / \mathbf{s}$ & 1 & 3 & 71 & 74 & 678 & 1447 \\
$\mathbf{L} / \mathbf{m i n}$ & 60 & 180 & 4260 & 4440 & 40680 & 86820 \\
$\mathbf{g p m}$ & 16 & 48 & 1129 & 1177 & 10780 & 23007 \\
\hline
\end{tabular}

The magnitude of the flow rate at $\mathrm{BC} 6 / 9$ was $\sim 10$ times greater than the combined flow rates of all four tributaries (BC-4, BC-5, BC-7, and BC-8) that flow into Beaver Creek between $\mathrm{BC}-3$ and $\mathrm{BC}-6 / 9$. If the flow rates $(\mathrm{Q})$ and concentrations $(\mathrm{C})$ are constant, then Equation 5.3.1.4 can be used.

$$
\frac{\mathrm{Q}_{\text {up }} \mathrm{C}_{\text {up }}+\mathrm{Q}_{\text {trib }} \mathrm{C}_{\text {trib }}}{\mathrm{Q}_{\text {down }}}=\mathrm{C}_{\text {down }}
$$

Where the subscripts "up", "trib", and "down" refer to conditions upstream of the tributary, in the tributary, and downstream of the tributary, respectively. Therefore, if $\mathrm{Q}_{\text {trib }}<<\mathrm{Q}_{\text {up }}$, then $\mathrm{C}_{\text {down }} \sim \mathrm{C}_{\text {up }}$. Furthermore, Beaver Creek was found to be a gaining stream below Gatzmer, Tummala (2003), which produced an even more marked dilution effect. The input of groundwater to Beaver Creek also explains the, otherwise unaccounted for, $\sim 10,000 \mathrm{gpm}$ increase in flow from $\mathrm{BC}-3$ to $\mathrm{BC}-6 / 9$. As a result, the dilution process effectively "drowned out" the higher concentrations of dissolved metal ions and acidity that were present in $\mathrm{BC}-4, \mathrm{BC}-5, \mathrm{BC}-7$, and $\mathrm{BC}-8$ as the respective waters entered the main stem of Beaver Creek.

Along with the grab sample data presented previously, the water at both the BC-3 and BC6/9 grab sample site were further characterized with fish and macroinvertebrate data. The fish and macroinvertebrate data which represented BC-3 were collected from 
BC-15, an additional sampling site located on the main stem of Beaver Creek just upstream of BC-3. Using the fish and macroinvertebrate data collected from the BC-15 and BC-6/9 grab sample sites, several index scores were calculated which characterized the stream condition based on a numeric scale. The fish communities at the $\mathrm{BC}-15 \mathrm{BC}-$ 6/9 sampling sites were determined to be moderately diversified, moderate to poor communities, and in poor condition from the index scores calculated from the fish indices. From the macroinvertebrate data, the WVSCI score for the streams at both BC15 and BC-6/9 indicated a "fair" stream rank or category.

\subsubsection{Tributary Sites}

The water chemistry at the Iron Pond sampling station (BC-4), the Slate Culvert sampling station (BC-5), the Chaffee sampling station (BC-7), and the Hawkins sampling station (BC-8) were representative of the water quality characteristics expected of streams which were impacted by acid drainage.

At all of the tributary water quality sampling sites (BC-4, BC-5, BC-7, and BC-8) the average $\mathrm{pH}$, iron, manganese, and aluminum values all exceeded the standards set forth for the support of aquatic life (Table 4.2.1). Along with elevated metals concentrations, the waters of the four tributary water quality sampling sites were determined to be net acidic. The net acidity of the waters at the BC-7 and BC- 8 water quality sampling sites was illustrated by the $\mathrm{pH}$ data collected by the YSI Sondes from each respective site. The plots of the $\mathrm{pH}$ data collected by the YSI Sondes from the four tributary sites are presented in Appendix A. With the exception of a spike in the $\mathrm{pH}$ data from $\mathrm{BC}-7$ on $6 / 25 / 02$ and $\mathrm{BC}-8$ on $8 / 15 / 01$, the $\mathrm{pH}$ recorded at the $\mathrm{BC}-7$ and $\mathrm{BC}-8$ 
sampling sites were substantially less than the $\mathrm{pH}$ data collected along the main channel of the watershed, which indicated that the waters at $\mathrm{BC}-7$ and $\mathrm{BC}-8$ were much more acidic than the water at BC-1. The spikes in the YSI Sonde $\mathrm{pH}$ data collected at the BC-7 and BC-8 sampling sites could not be fully explained.

The elevated concentrations of dissolved metal ions and conductivity values collected from the BC-7 and BC-8 water quality sampling sites were also demonstrated by the YSI Sonde specific conductance data collected from the BC-7 and BC-8 sampling sites. With the exception of several sharp decreases in the specific conductance data at the $\mathrm{BC}-7$ and $\mathrm{BC}-8$ sampling sites, the specific conductance recorded from the $\mathrm{BC}-7$ and BC-8 sampling sites is considerably higher than the specific conductance recorded along the main channel of the watershed. The rapid, large magnitude decreases in the specific conductance data from the $\mathrm{BC}-7$ and $\mathrm{BC}-8$ sampling sites were not completely understood.

The net acidity of the water, along with elevated dissolved metals concentrations observed at the four tributary sampling sites represented substantial sources of water quality impairment associated with drainage from mine spoil piles. The lower $\mathrm{pH}$ and increased specific conductance recorded at the BC-7 and BC-8 sampling sites were supported by the data collected from the grab sample data for the sites. The assumption was made that the same characteristics held true for the two sample sites (BC-4 and BC5) that were not YSI Sonde deployment locations.

Along with the grab sample and YSI Sonde water quality data presented previously, the water at the four tributary grab sample sites were further characterized with fish and macroinvertebrate data. The BC-5, BC-7, and BC-8 grab sample sites were 
sampled for fish population and the $\mathrm{BC}-4$ and $\mathrm{BC}-7$ grab sample sites were sampled for macroinvertebrates during the study period. Since no fish were collected during the sampling of the BC-5, BC-7, and BC-8 grab sample sites, no index scores could be calculated, thus no characterization could be made. Although no characterization was made, the conclusion was made that the fish abundance and diversity would be low in the tributary sites given the water quality impairments described previously. From the macroinvertebrate data collected from the $\mathrm{BC}-4$ and $\mathrm{BC}-7$ grab sample sites, characterizations of "very poor" stream condition were made for both grab sample sites. Again, the same "very poor" stream condition conclusion could be drawn for the BC-5 and BC-8 sample sites given the similarity of water quality impairment at each of the tributary sites.

\subsubsection{Remediation Recommendations Below Gatzmer}

Due to the presence of active mine water treatment facilities in addition to spoil/waste areas from historic mining activities; full restoration to the pre-impacted conditions was not likely to be feasible below BC-3. However, there was abundant potential for the remediation of impaired water and minimization of future sources of water quality impairment below BC-3.

The high volume flow rates in the main stem of Beaver Creek between BC-3 and BC-6/9 (Table 5.4.1.1) made the use of active and/or passive treatment systems impractical for implementation. Flow rates of about 100 gpm have generally been the upper limit for passive treatment systems because of size and area restrictions (Skousen et.al., 1996). Furthermore, the similarity of the grab sample water quality data from BC- 
3 and $\mathrm{BC}-6 / 9$ indicated that most of the water quality impairment present in the main stem of Beaver Creek was originated in the four tributary sampling sites. Therefore, the treatment and remediation of all impaired tributaries that flowed into Beaver Creek was concluded to be the most feasible method for the remediation of the main channel.

Due to the expense and maintenance intensive nature of chemical treatment for remediation (Skousen et.al., 1996), passive treatment "trains" are recommended for the remediation of the impaired tributaries. A combination of passive treatment processes could be used to impart alkalinity on receiving stream waters, facilitate the removal of dissolved metals, and allow for the biochemical reduction of dissolved sulfate (Skousen et.al., 1996).

Dissolved oxygen concentrations of $9.46 \mathrm{mg} / \mathrm{L}$ and $9.34 \mathrm{mg} / \mathrm{L}$ were recorded from the BC-7 and BC-8 sampling sites by the YSI Sondes, respectively. Although dissolved oxygen concentrations were not monitored at $\mathrm{BC}-4$ and $\mathrm{BC}-5$, the assumption that BC-4 and BC-5 had comparable dissolved oxygen concentrations to BC-7 and BC-8 was made. The assumption that $\mathrm{BC}-4$ and $\mathrm{BC}-5$ had high dissolved oxygen concentrations was supported by the fact that both of the tributaries flowed in an open channel setting and both tributaries underwent adequate elevation change to induce turbulence in the streams. Due to the abundant concentrations of dissolved oxygen in the impaired tributaries, there was a high possibly of elevated concentrations of dissolved ferric iron. Therefore, the construction of anaerobic/compost wetlands at the BC-4 and BC-5 sampling sites is recommended. Anaerobic/compost wetlands generate alkalinity through a combination of bacterial sulfate reduction and limestone dissolution (Skousen et.al., 1998). To increase the production of alkalinity and precipitation of dissolved metal 
ions, the construction of an open limestone channel followed by a sedimentation pond prior to the anaerobic/compost wetlands at both the $\mathrm{BC}-4$ and $\mathrm{BC}-5$ sites was recommended. In each combined approach to passive water quality management natural stream design principles may be incorporated to increase the overall benefit of remediation.

The flow rates measured at the $\mathrm{BC}-7$ and $\mathrm{BC}-8$ sampling sites (Table 5.4.1.1) were considerably higher than the $100 \mathrm{gpm}$ limit for the use of passive treatment systems (Skousen et.al., 1996). To facilitate the addition of alkalinity to the waters of BC-7 and BC-8, the construction of OLCs upstream of the "beaver" impoundments located on both tributaries is recommended. By placing the OLCs upstream of the impoundments, the impoundments become settling ponds for which metal precipitates can deposit. The impoundments should be of adequate size to facilitate the settling process necessary to remove all or most of the metal hydroxides that are formed. As the dimensions of the impoundments were not "designed" for any specific use, provisions may need to be made for the future removal of sediment from the impoundments.

Although the $\mathrm{BC}-4, \mathrm{BC}-5, \mathrm{BC}-7$, and $\mathrm{BC}-8$ sampling sites were identified as the major sources of impaired water entering Beaver Creek, it is important to realize that those four tributaries are most likely NOT the only sources of impairment to the watershed. During any subsequent remediation attempts on the Beaver Creek watershed it is recommended to sufficiently monitor every tributary entering the main channel of Beaver Creek and design any treatment facilities accordingly.

Future production of water quality impairment below BC-3 is possible from the disturbance of pyretic material buried in existing spoils piles. To decrease the potential 
for exposure of additional pyretic material several precautions can be taken. If possible, disturbance of mine spoils containing pyretic material should be avoided completely. When the disturbance of such pyretic materials is unavoidable the following methods could be used to minimize adverse impacts. Perform a quantitative acid base accounting of cut $\&$ fill to estimate alkaline admix needs. Implement active treatment during construction to provide sufficient defense against the inadvertent liberation of acidic water during construction. Design and implement passive treatment "trains" after construction is completed to minimize future degradation and to affect some net positive change in water quality through alkaline addition.

While it is necessary to deal with potential acidic drainage resulting from the construction of Corridor $H$ through mine spoils in the Beaver Creek drainage, it is equally important to address sources of water impairment originating above the roadway alignment, as such waters will be drained to Beaver Creek via roadway culverts. Failure to address upgrade sources of acid dissolved metals, and sediment would result in additional loading to passive treatment processes incorporated into roadway design and construction, which may render such mechanisms ineffective. However, it is recognized that the management of sources of water impairment located outside the roadway alignment will require a coordinated effort on the part of multiple stakeholders. Thus, it is recommended that the $W V$ Division of Highways work in conjunction with regulatory and resources agencies such as the WV Department of Environmental Protection (Mining and Reclamation) and the WV Department of Natural Resources to leverage resources in an effort to affect a watershed-scale improvement in environmental conditions. 


\subsection{CONCLUSIONS AND RECOMMENDATIONS}

\subsection{Tributaries}

The tributaries of Beaver Creek (BC-4, BC-5, BC-7, and BC-8) monitored as part of this study were determined to be the main inputs of AMD into Beaver Creek, with BC5 (slate culvert) having the most severely degraded water quality of four. Based on the grab sample data, all four of the sites exhibited low $\mathrm{pH}$ and alkalinity values and elevated acidity, and metal ion concentrations. The grab sample data were supported by the data collected by the YSI Sondes from the BC-7 and BC-8 sampling sites.

The macro-invertebrate and fisheries data collected from the four tributary sites also supported the conclusion that the tributaries were the major sources of AMD input to Beaver Creek. The tributaries sampled for macro-invertebrates (BC-4 and BC-7) both scored very poor on the WVSCI. Additionally, no fish were captured at the three tributary sites (BC-5, BC-7, and $\mathrm{BC}-8)$. The lack of biological organisms present in the four tributary sampling sites was indicative of severely degraded environmental conditions, most likely due to the existence of AMD in the streams.

\subsection{Main Channel}

Through the analysis of the grab sample data collected from the main channel of Beaver Creek, the main channel was divided into two sections. Above Gatzmer (BC-3) the water quality was the least impacted by AMD and most easily rendered suitable for the support of aquatic organisms. Below Gatzmer, the adverse affects of AMD could be seen in the grab sample data and macro-invertebrate and fish data. 


\subsubsection{Above Gatzmer}

The water at $\mathrm{BC}-1$ was the least impacted by AMD of all the sampling sites in the Beaver Creek watershed. At the $\mathrm{BC}-1$ sampling site, the average $\mathrm{pH}$ was only slightly below and the average aluminum concentration was slightly above the ranges set for the support of aquatic life. Additionally, BC-1 was determined to be weakly buffered. Along with the grab sample data from BC-1, the score of "good" on the WVSCI (the only site in the study to attain this score) and the presence of one brook trout (Salvelinus fontinalis), along with three other taxa, indicated that $\mathrm{BC}-1$ could be a suitable location to be reclaimed to a native trout fishery.

The water quality at the BC-2 sampling station was more indicative of impacts associated with AMD than the water from BC-1. The elevated concentrations of metal ions present at the BC-2 sampling site were accompanied by elevated concentrations of nitrogen, due to the anhydrous ammonia treatment facility located on a tributary which emptied into Beaver Creek in the vicinity of the BC-2 sampling site. Thus, the conclusion was drawn that the impacts observed at BC-2 were due mostly to the discharge of the active AMD treatment facility located near BC-2.

\subsubsection{Below Gatzmer}

The water quality at the BC-3 and BC-6/9 sampling sites was similar from both the grab sample data and the macro-invertebrate and fish data. The highest average $\mathrm{pH}$ and alkalinity values in the watershed were observed at the $\mathrm{BC}-3$ sampling station. The elevated $\mathrm{pH}$ and alkalinity recorded from $\mathrm{BC}-3$ were most likely a result of the periodic treatment of BC-3 with limestone sands by the WVDEP, and the discharge from an active 
anhydrous ammonia treatment facility that emptied into Beaver Creek just upstream of BC-3. Evidence of the anhydrous ammonia facility was also present in the elevated nitrogen concentrations recorded at the $\mathrm{BC}-3$ sampling site. The $\mathrm{pH}$, alkalinity, and metal ion values change very little between $\mathrm{BC}-3$ and $\mathrm{BC}-6 / 9$, which was the stretch of Beaver Creek wherein the four AMD impacted tributaries (BC-4, BC-5, BC-7, and BC-8) converge with the main channel of Beaver Creek. Additionally, both BC-3 and BC-6/9 scored "fair" based on the WVSCI metric and had very similar results from the fish sampling. The lack of anticipated change in the water quality conditions between BC-3 and BC-6/9 was explained through the dilution of acid sources by watershed waters. As Beaver Creek flows from BC-3 to BC-6/9 the average flow in the main channel doubles in magnitude with only about $20 \%$ of the magnitude change coming from the four tributaries mentioned above. Thus, the metal ion and acidity concentrations present in the discharge of the four tributaries were effectively "drowned out" by the much larger volume of water in the main channel of Beaver Creek.

\subsection{Recommendations}

As a result of the acidic nature of the soil in the Beaver Creek watershed and the abundance of historically mined lands, it is recommended that great care be taken to avoid the further disturbance of acidic soils during construction of Corridor- $\mathrm{H}$ in the watershed. The method of analyzing core samples via leaching tests and acid-base accounting is recommended along the section of Corridor- $\mathrm{H}$ to be constructed in the Beaver Creek watershed. The core sample analysis data could then be used to determine the best way to manage the material being disturbed by the construction. Any of the 
prevention techniques described in Chapter 2 could be implemented to avoid the future production of AMD.

\subsubsection{Above Gatzmer}

The reclamation of the reach of stream encompassing the BC-1 sampling site to a native trout fishery is recommended. The addition of limestone sands should be sufficient to raise the $\mathrm{pH}$ and alkalinity concentration of the water. The increase in $\mathrm{pH}$ and alkalinity will also help to precipitate metal ions present in the water. The reclamation of the $\mathrm{BC}-1$ sampling site to a native trout fishery would require the cooperation of several State and Federal agencies including the WVDEP and WVDNR to be successful. The dosing of the upper Beaver Creek reach with limestone sands and the subsequent increase in alkalinity and buffer capacity of the water should be sufficient to remediate the water at the $\mathrm{BC}-2$ sampling site.

\subsubsection{Below Gatzmer}

The recommended remediation methods for tributaries on which the BC-4 and BC-5 sampling sites were located include a combination of passive treatment systems. The combination of passive systems began with open limestone channels (OLCs) being constructed near the headwaters of the respective tributaries followed by settling basins. If possible the OLCs should be constructed on a slope of $20 \%$ or more to reduce the amount of limestone armoring that may occur. The effluent from the settling basins should then be discharged into anaerobic/compost wetlands to "polish" the water and remove any residual metal ions from the water for discharge into the main channel of 
Beaver Creek. During the construction of Appalachian Corridor H, the treatment of the $\mathrm{BC}-5$ and possibly the $\mathrm{BC}-4$ tributaries via active treatment is recommended. The treatment of the $\mathrm{BC}-5$ and $\mathrm{BC}-4$ tributaries may be necessary due to the acidic nature of the soils in the surrounding area. As construction proceeds, the disturbance of the acidic soils is likely to produce much more severely impaired water quality conditions than what has already been observed at the BC-5 and BC-4 sampling sites.

The tributaries on which $\mathrm{BC}-7$ and $\mathrm{BC}-8$ were located had average flows that were above the $100 \mathrm{gpm}$ limit thus limiting the types of passive treatment systems that could be employed. The recommended treatment system for the BC-7 and BC-8 tributaries was the construction of OLCs followed by settling basins, respectively. To minimize the amount of construction needed for the two systems, it was recommended that the OLCs be constructed upstream of impoundments located on both the BC-7 and BC-8 tributaries. Thus, the impoundments would serve as the settling basins for the OLCs. As with the BC-4 and BC-5 treatment chains, the OLCs constructed on the BC-7 and BC- 8 tributaries should be built on a slope of $20 \%$ of greater to reduce the amount of limestone armoring that may occur.

There were no direct recommendations for the remediation of the main channel of Beaver Creek below the BC-3 sampling site, however, the remediation of the four tributaries (BC-4, BC-5, BC-7, and $\mathrm{BC}-8)$ should provide adequate remediation indirectly. However, it is recommended that the main stem of Beaver Creek continue to be monitored after implementation of the tributary treatment systems. The possibility does exist that the same dilution effect that "drowned out" the affects of the AMD 
impaired tributaries may do the same to the added alkalinity entering the main channel of Beaver Creek. 


\subsection{REFERENCES}

Barbour, M.T., J.Gerritsen, B.D. Snyder, and J.B. Stribling. (1999). Rapid Bioassessment Protocols for Use in Streams and Wadeable Rivers: Periphyton, Benthic Macroinvertebrates andFish, Second Edition. EPA 841-B-99-002. U.S. Environmental Protection Agency; Office of Water; Washington, D.C.

Barrett, M. E., Malina, J. F. Jr., Charbeneau, R. J., and Ward, G. H. (1995). "Characterization of highway runoff in the Austin, TX Area." Center for Research in Water Res.: Tech. Report CRWR 263, University of Texas at Austin, Austin, TX.

Brady, K. B. C., Perry, E. F., Beam, R. L., Bisko, D. C., Gardner, M. D., and Tarantino, J. M. (1994) "Evaluation of acid-base accounting to predict the quality of drainage at surface coal mines in Pennsylvania, U.S.A." Proc., 3rd Int. Conf. On the Abatement of Acidic Drainage, 1, April 24-29, 138-147.

Brodie, G A., Britt, C. R., Taylor, H., Tomaxzewski, T. and Turner, D. (1990). "Passive anoxic limestone drains to increase effectiveness of wetlands acid drainage treatment systems." In: Proceedings of the $12^{\text {th }}$ National Association of Abandoned Mined Land Cnference, Breckinridge, CO.

Brooks, R. P. (1984). "Optimal Designs for Restored Wetlands." Contribution No. 264, Depart. of Biology, Pennsylvania State University, University Park, PA, 19-29.

Button, K., Stough, R., and Arena, P. (1999). "Dealing with Environmental Legacy Effects: The Economic and Social Benefits of Acid Mine Drainage Remediation." Int. J. Environment and Pollution, Vol. 12, No. 3, 459-475.

Caruccio, F. T., Hossner, L. R., and Geidel, G. (1988). "Pyretic materials: Acid drainage, soil acidity, and liming." Reclam. of Surface-Mined Lands, 1, 159-190.

Chessman, B. C., Robinson, D. P. and Hortle, K. G. (1987). "Changes in the riffle macroinvertebrate fauna of the Tanjil River, South-Eastern Australia, during the construction of Blue Rock Dam." Regulated Rivers Research and Management, 1:317329.

Clesceri, L.S.; Greenberg, A.E.; and Eaton, A.D. (1998). Standard Methods for the Examination of Water and Wastewater, 20 ${ }^{\text {th }}$ Edition, American Public Health Association, American Water Works Association, Water Environment Federation, Baltimore, MD.

Cohen, R. H. and M. W. Staub. (1992). "Technical manual for the design and operation of a passive mine drainage treatment system." Technical report prepared for the U.S. Bureau of Reclamation, December, 1992. 
Eger, P. and Lapakko, K. (1989). "Nickel and copper removal from mine drainage b a natural wetland.” U.S. Bureau of Mines Circular 9183, pp. 301-309.

Faulkner, B., and J Skousen (1998). "Acid Mine Drainage Inventory in West Virginia," Green Lands, 28, 3.

Faulkner, B. B., and J. G. Skousen (1994). "Treatment of acid mine drainage by passive treatment systems." International Land Reclamation and Mine Drainage Conference, U.S. Bureau of Mines SP 06A-94, April 24-29, Pittsburgh, PA, 250.

Ferguson, K. D., and Morin, K. A. (1991). "The prediction of acid rock drainage lessons from the database." Proc., $2^{\text {nd }}$ Int. Conf. on the Abatement of Acidic Drainage, 83-106.

Gray, N. F. (1996). "A substrate classification index for the visual assessment of the impact of acid mine drainage in lotic systems." Water Research, 30(6), 1551-1554.

Hayter, A.J. (1996). Probability and Statistics for Engineers and Scientists, PWS Publishing Co., Boston, MA.

Hedin, R. S. and R. W. Nairn. (1993). Contaminant removal capabilities of wetlands constructed to treat coal mine drainage. p. 187-195. In: G. A. Moshiri (ed.), Constructed wetlands for water quality improvement. Lewis Publishers, Boca Raton, FL.

Hedin, R. S. and G. R. Watzlaf. (1994). The effects of anoxic limestone drains on mine water chemistry. p. 185-194. In: The international land reclamation and mine drainage conference and the third international conference on the abatement of acidic drainage, Pittsburgh, PA, April 24-29, 1994.

Henrot, J., and Wieder, R. K. (1990). "Processes of iron and manganese retention in laboratory peat microcosms subjected to acid mine drainage." J. Environ. Qual., 19, 312320.

Jenkins, M., Wade, E., Fletcher, J., and Hankins, J. (1995). "Economic Analysis of NonTraditional Water Resources for Aquaculture in West Virginia." Technical Report funded in part by Appalachian Regional Commission, West Virginia University, Morgantown, WV.

Joostie, S., and C. Thirion. (1999). "An Ecological risk assessment for a South African acid mine drainage." Wat. Sci. Tech., Vol. 39, No. 10-11, pp. 297-303.

Karr, J. R. (1981). Assessment of biotic integrity using fish communities. Fisheries 6:21-27. 
Karr, J. R., K. D. Faush, P. L. Angermeier, P.P. Yant, and I. J. Schlosser. (1986). Assessing biological integrity in running waters: a method and its rationale. Illinois Natural History Survey Special Publication 5. Champaign, Illinois.

Kuyucak, N., and P. St-Germain (1995). "Evaluation of sulfate reducing bacteria and related process parameters for developing a passive treatment method." Proceedings of the 1995 Engineering Foundation Conference on Minerals Processing II, 287.

Lange, C. R. and Lambert, K. E. (1995). "Biomonitoring.” Water Envirnmenta Research. 67(4), 738-748.

Lewis, G. N. and M. Randall. (1921). Journal of American Chemical Society Vol. 43: 1111.

Maestri, B., and B. N. Lord (1987). "Guide for mitigation of highway stormwater runoff pollution." Science of the Total Environment, 59, 467-476.

Magurran, A. E. (1988). Ecological Diversity and Its Measurements. Princeton University Press, Princeton, NJ.

Meade, J.W. (1989). Aquaculture Management. Van Nostrand Reinhold, New York.

Meek, A. (1991). "Evaluation of acid prevention techniques used in surface mining." Environ. Mngmt. for the 1990's, 167-172.

Mitsch, W. J. and J. G. Gosselink. (2000). Wetlands. $3^{\text {rd }}$ Edition. John Wiley \& Sons Inc., New York, NY.

Murawski, S. (1994). "Heavy metal removal using peat/wetland treatment." National Conference on Environmental Engineering, 408.

Pearson, F. H., and A. J. McDonnell. (1975). "Use of crushed limestone to neutralize acid wastes. No. EE1, Proc. Paper 11131. J. Environ. Eng. Div., Am. Soc. Civil Eng. 101:139-158.

Roth, N. E., M. T. Southerland, G. Mercurio, J. C. Chaillou, P. F. Kazyak, S. S. Stranko, A. P. Prochaska, D. G. Heimbuch, and J. C. Seibel. (1999). State of Streams: 1995-1997 Maryland Biological Stream Survey Results. Maryland Department of Natural Resources: $401 \mathrm{pp}$.

Russell, L. L. Dec, (1976). "Chemical Aspects of Groundwater Recharge with Wastewaters.” Ph.D. Thesis, University of California, Berkeley.

Sikora, F. J., Behrends, L. L., Brodie, G. A., and Bulls, M. J. (1996). "Manganese and trace metal removal in successive anaerobic and aerobic wetlands." Proc., $13^{\text {th }}$ Annual Meeting Amer. Soc. for Surface Mining and Reclamation, Knoxville, TN, 560-579. 
Skousen, Jeffrey G., A. Rose, G. Geidel, J. Foreman, R. Evans, and W. Hellier. (1998). A Handbook of Technologies for Avoidance and Remediation of Acid Mine Drainage. National Mine Reclamation Center, Morgantown, WV.

Skousen, Jeffrey G. and Paul Ziemkiewicz. (1996). Acid Mine Drainage Control and Treatment. $2^{\text {nd }}$ Edition, West Virginia University, Morgantown, WV.

Smith, R., Sobek, A., Arkle, T., Sencindiver, J., and Freeman, J., (1996). Extensive Overburden Potential for Soil and Water Quality, EPA-600/2-76-184, U.S. Environmental Protection Agency, Cincinnati, OH.

Snoeyink, Vernon L. and D. Jenkins. (1980). Water Chemistry. John Wiley \& Sons, Inc, New York, NY.

Sobek, A.A., Schuller, W.A., Freeman, J.R., and Smith, R.M. (1978). Field and Laboratory Methods Applicable to Overburdens and Minesoils. PEA-600/2-78-054. U.S. Environmental Protection Agency, Cincinnati, OH.

SPSS (1997). SigmaStat 2.0 User's Manual, ImageStream Graphics \& Presentation Filters, Chicago, IL.

Stark, L. R., Williams, F. M., Stevens, Jr., S. E., and Eddy, D. P. (1994). "Iron removal and vegetative cover at the Simco constructed wetland: An appraisal through year eight of operation." Proc., 3rd Int. Conf. On the Abatement of Acidic Drainage, 1, April 24-29, 89-98.

Stephens, K. December, (2003). "Characteristics of Wetland Soils in the Beaver Creek Watershed." M.S. Thesis, West Virginia University, Morgantown, WV.

Stumm, Werner and J. J. Morgan. (1996). Aquatic Chemistry Chemical Equilibria and Rates in Natural Waters, $3^{\text {rd }}$ Edition, John Wiley \& Sons, Inc, New York NY.

Thrasher, M.H. (1983). "Highway impacts on wetlands: assessment, mitigation, and enhancement measures." Trans. Res. Rec., 948, 17-20.

Tummala, V. August. (2003). "Hydrology of the Beaver Creek Watershed Using the TR-20 Model and the HEC-HMS Program" M.S. Thesis, West Virginia University, Morgantown, WV.

Turner, D. and D. McCoy. (1990). Anoxic alkaline drain treatment system, a low cost acid mine drainage treatment alternative. p. 73-75. In: D. H. Graves and R. W. DeVore (eds.), Proceedings 1990 National Symposium on Mining. (Lexington, KY, May 14-18 1990).

USEPA (2000). “A stream condition index for West Virginia wadeable streams." U.S. Environmental Protection Agency, Office of Water. 
USEPA (1999). "Monitoring water quality." Volunteer stream monitoring: A methods manual, U.S. Environmental Protection Agency, Office of Water.

USEPA (1998). "Guidance for data quality assessment. Practical methods for data analysis." EPA/600/R-96/084, U.S. Environmental Protection Agency, Office of Research and Development.

United States Environmental Protection Agency. (1997). "Volunteer Stream Monioring: A Methods Manual." EPA 841-B-97-003, U.S. Environmental Protection Agency, Washington, D.C.

Verweij, W., (2002). CHemical Equilibria for AQuatic Systems (CHEAQS),VersionL19.

Vile, M. A., and K. R. Wieder (1993). "Alkalinity generation by Fe (III) reduction versus sulfate reduction in wetlands constructed for acid mine drainage treatment." Water, Air, and Soil Pollution, 69(3-4), 425.

Wieder, R. K. (1988). "Determining the capacity for metal retention in man-made wetlands constructed for treatment of coal drainage." Mine Drainage and Surface Mine Reclam., 1, 375-381.

Wildeman, T. R., Updegraff, D. M., Reynolds, J. S., and Bolis, J. L. (1993). "Passive Bioremediation of Metals from Water Using Reactors or Constructed Wetlands." Emerging Techn. For Bioremediation of Metals, J. L. Means and R. E. Hinchee, eds., Lewis Publishers, Boca Raton, FL.

Yellow Springs Instruments (YSI), Inc. May (1999). Environmental Monitoring Systems Operations Manual.

Ziemkiewicz, P. F., Skousen, J. G., Brant, D. L., Sterner, P. L., and Lovett, R. J. (1997). "Acid mine drainage treatment with armored limestone in open limestone channels." $J$. Environ. Quality, 26(4), 1017-1024.

Ziemkiewicz, P. F., J. Skousen and R. Lovett. (1994). "Open limestone channels for treating acid mine drainage: A new look at an old idea." Green Lands 24:36-41. West Virginia Mining Reclamation Assoc., Charleston, WV.

Zurbach, P. E. (1996). Early results from calcium carbonate neutralization of two West Virginia rivers acidified by mine drainage. In: Proceedings, Seventeenth West Virginia Surface Mine Drainage Task Force Symposium, April 23, 1996, Morgantown, WV. 
APPENDIX A 

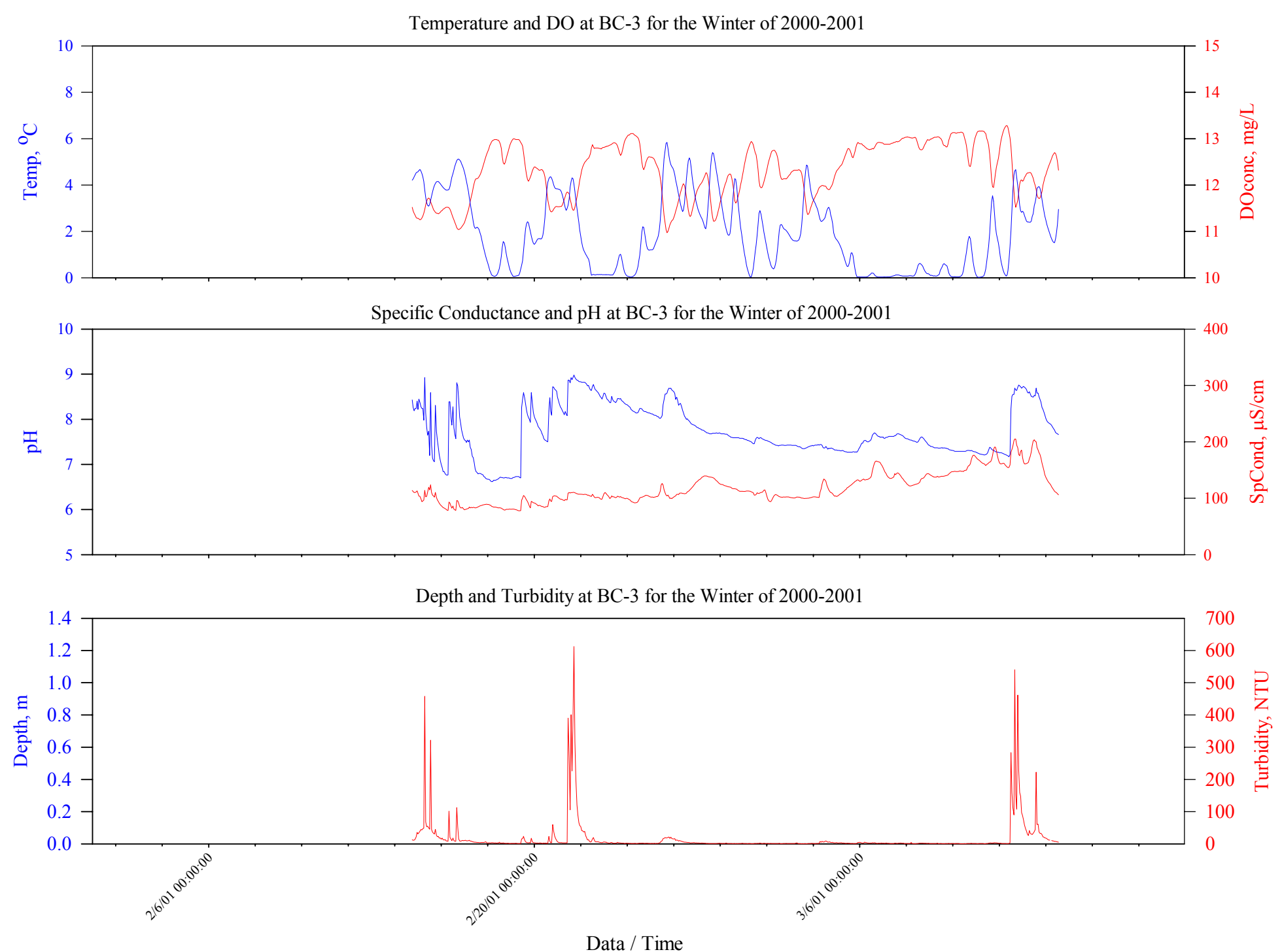

Figure A-1. Revised Sonde Data Collected During the Winter of 2000 to 2001 at BC-3. 

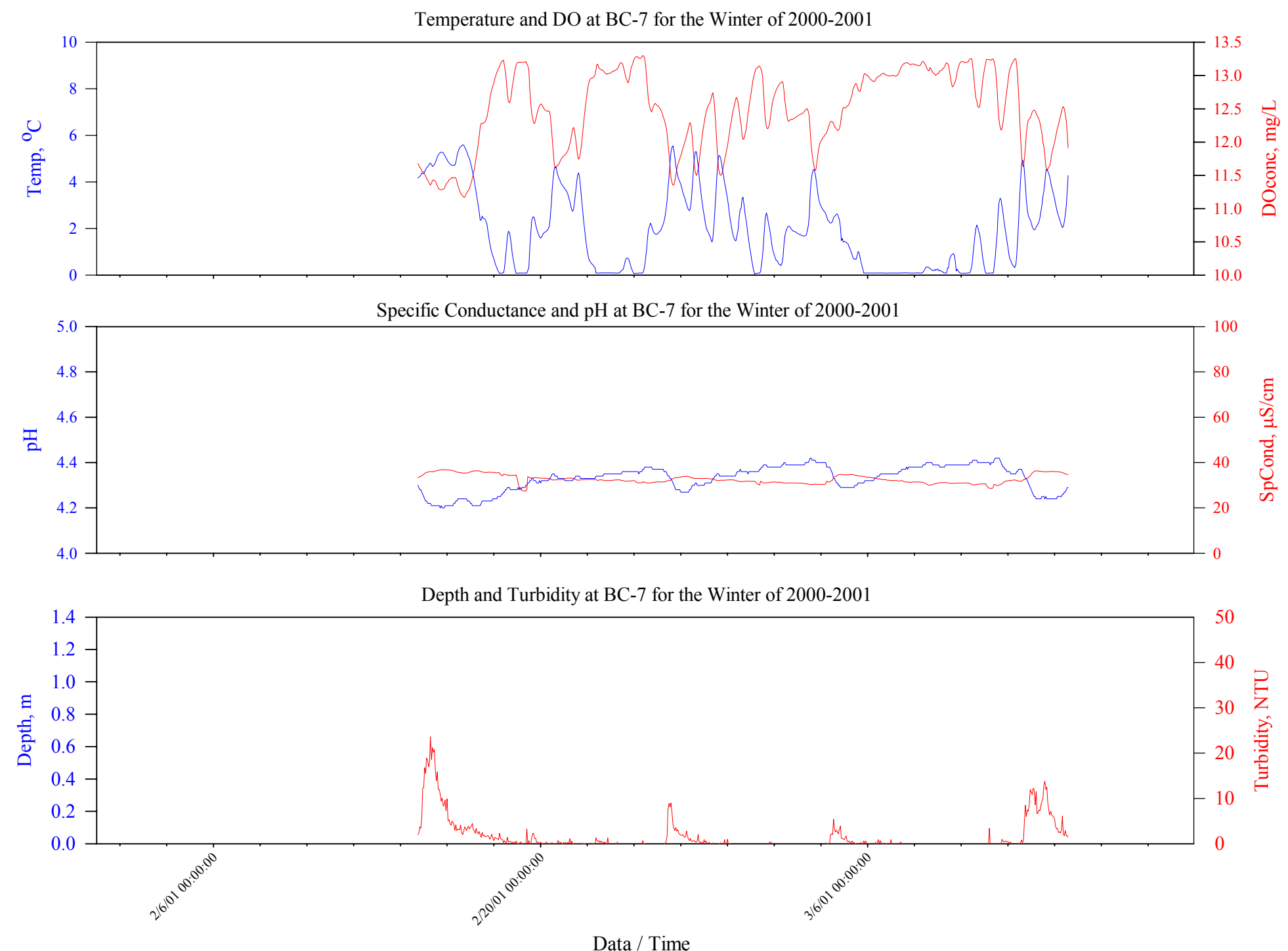

Figure A-2. Revised Sonde Data Collected During the Winter of 2000 to 2001 at BC-7. 

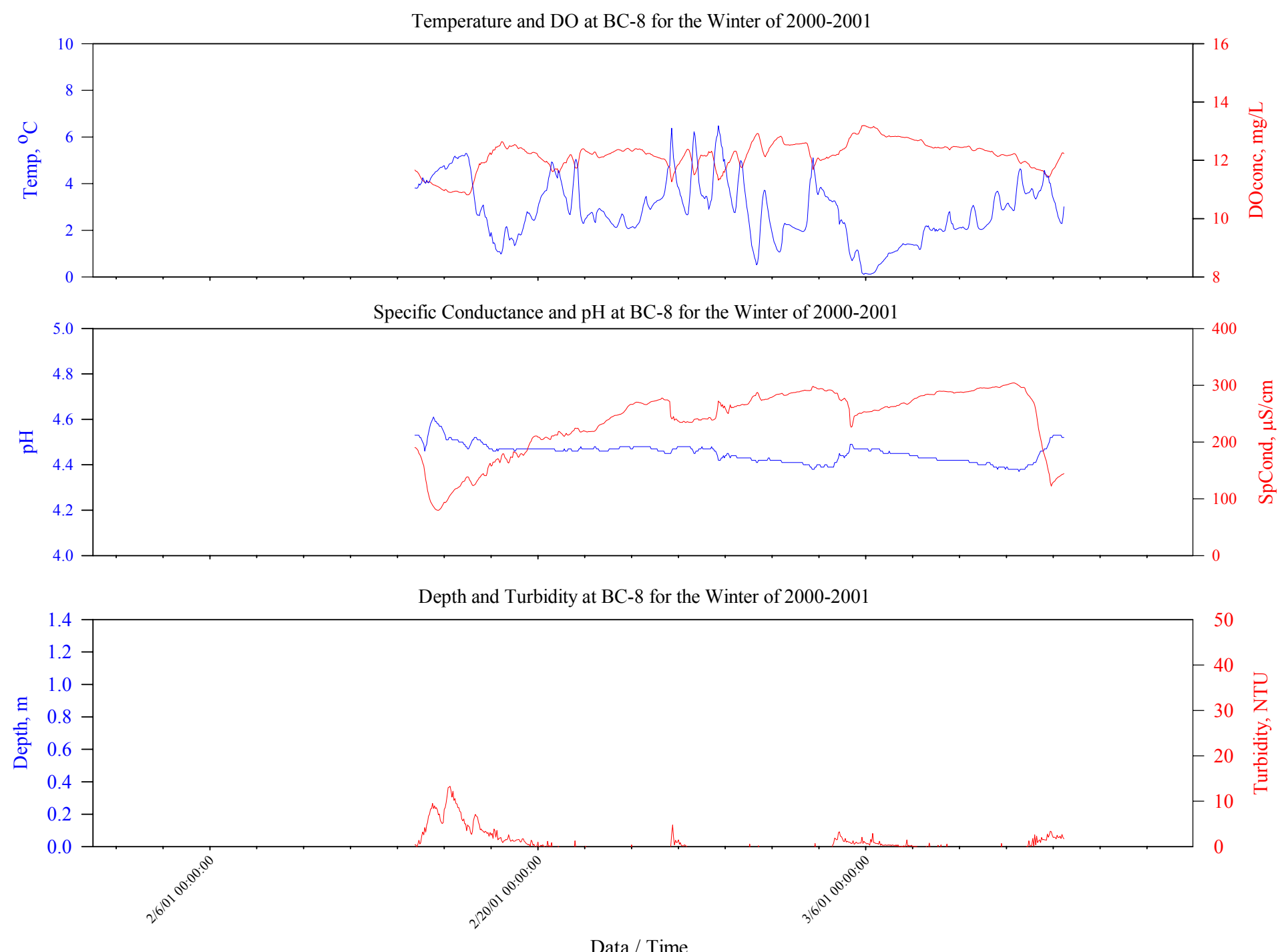

Figure A-3. Revised Sonde Data Collected During the Winter of 2000-2001 at BC-8. 

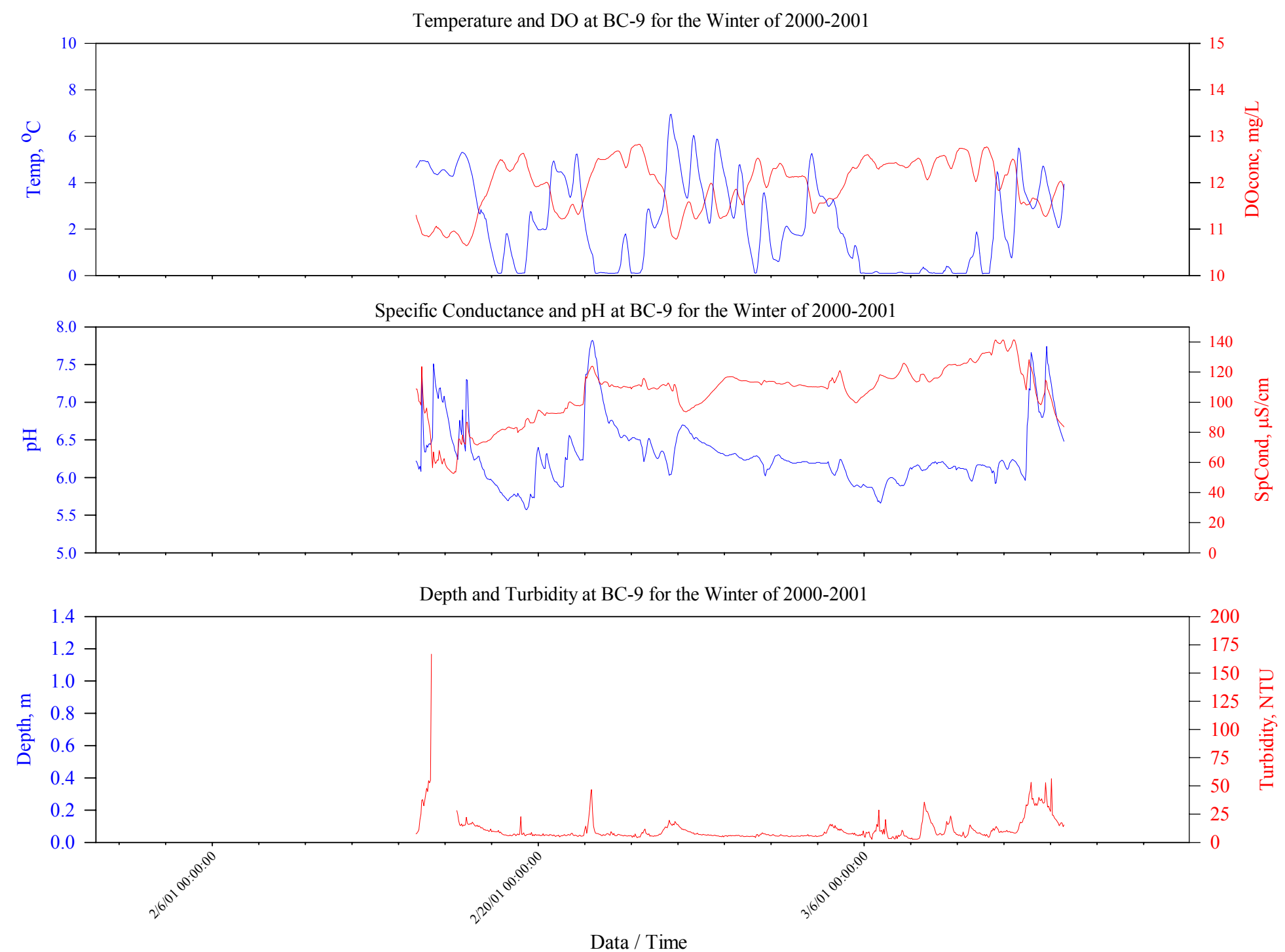

Figure A-4. Revised Sonde Data Collected During the Winter of 2000-2001 at BC-9. 

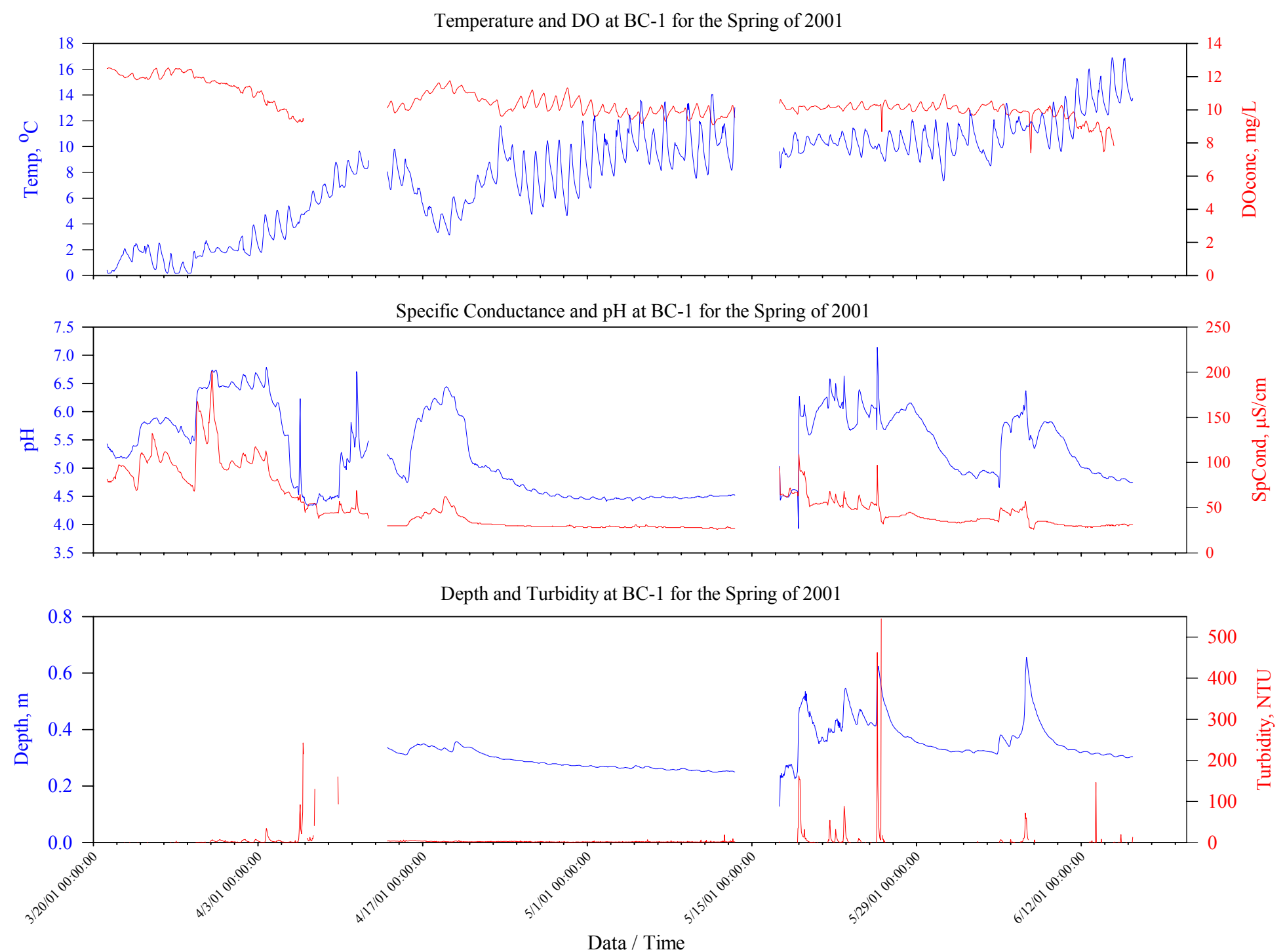

Figure A-5. Revised Sonde Data Collected During the Spring of 2001 at BC-1. 

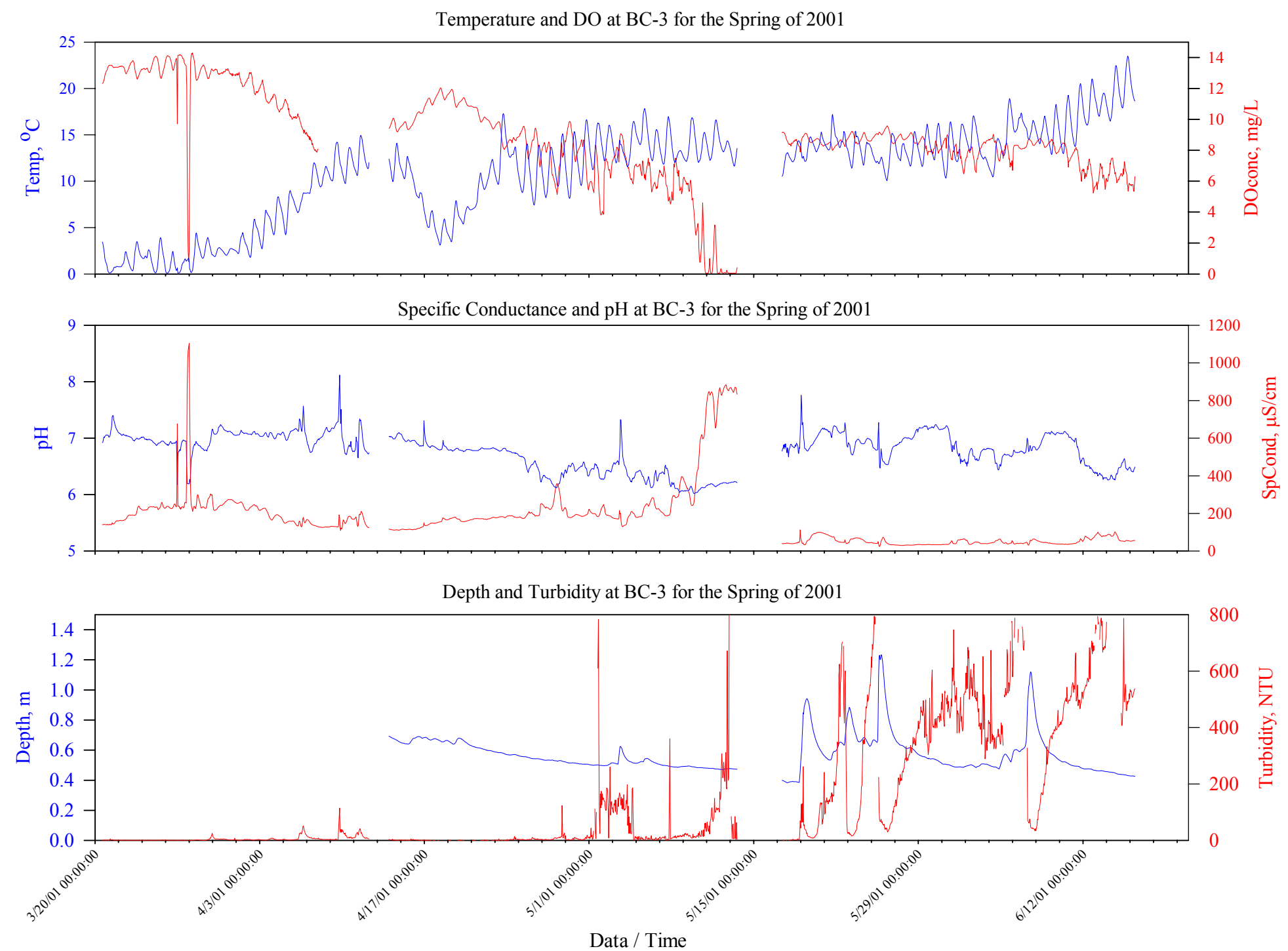

Figure A-6. Revised Sonde Data Collected During the Spring of 2001 at BC-3. 

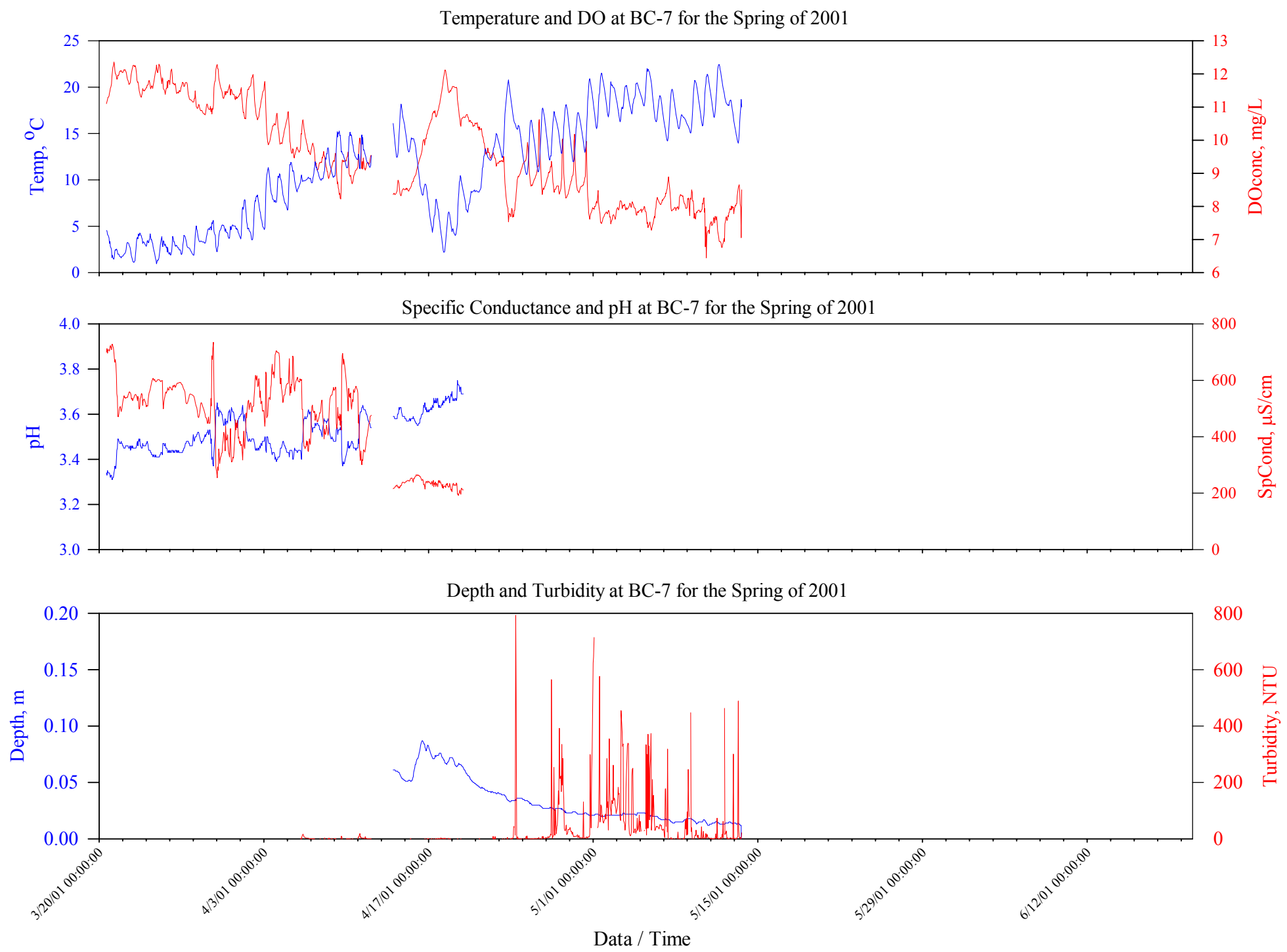

Figure A-7. Revised Sonde Data Collected During the Spring of 2001 at BC-7. 

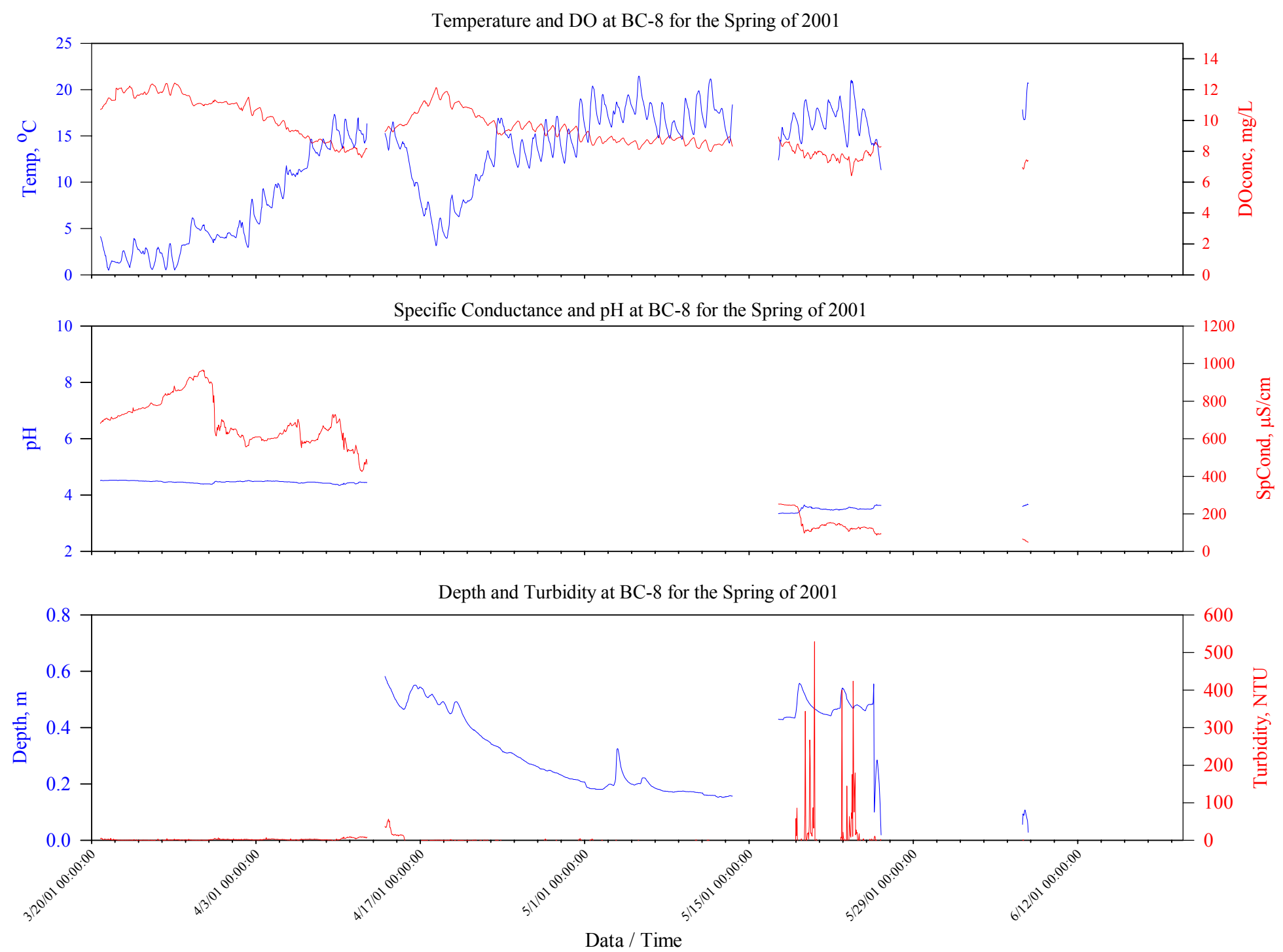

Figure A-8. Revised Sonde Data Collected During the Spring of 2001 at BC-8. 

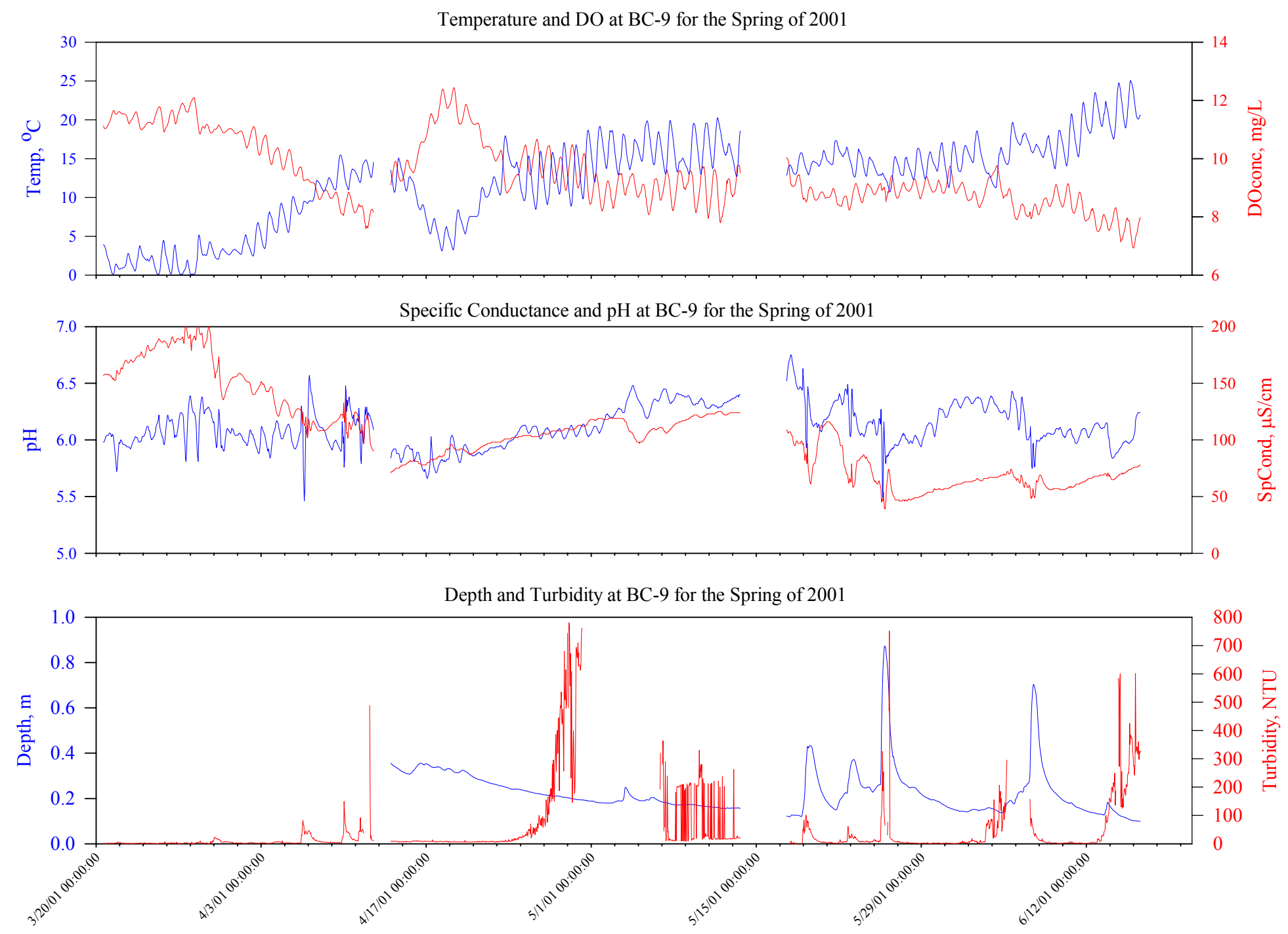

Figure A-9. Revised Sonde Data Collected During the Spring of 2001 at BC-9. 

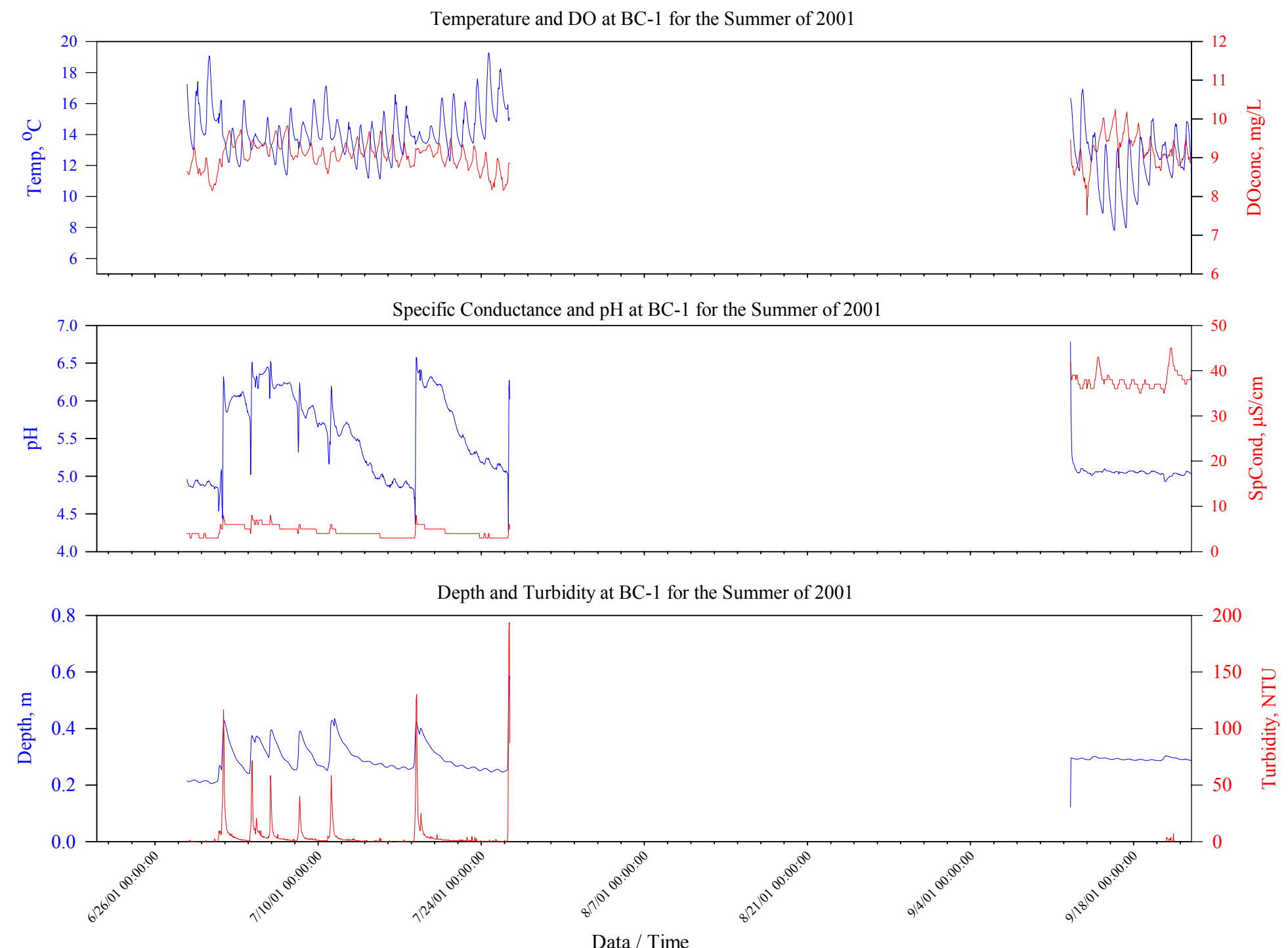

Figure A-10. Revised Sonde Data Collected During the Summer of 2001 at BC-1. 

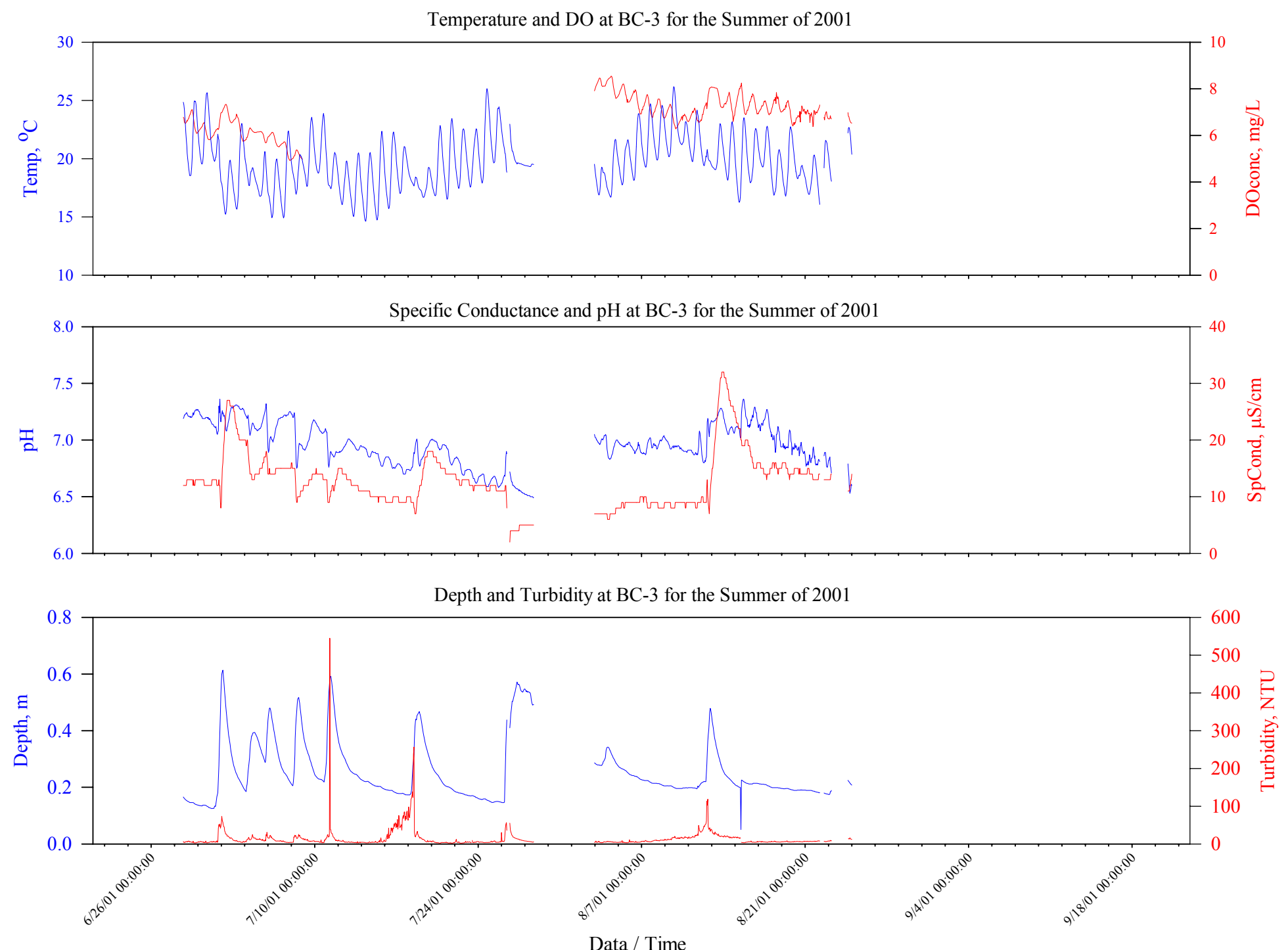

Figure A-11. Revised Sonde Data Collected During the Summer of 2001 at BC-3. 

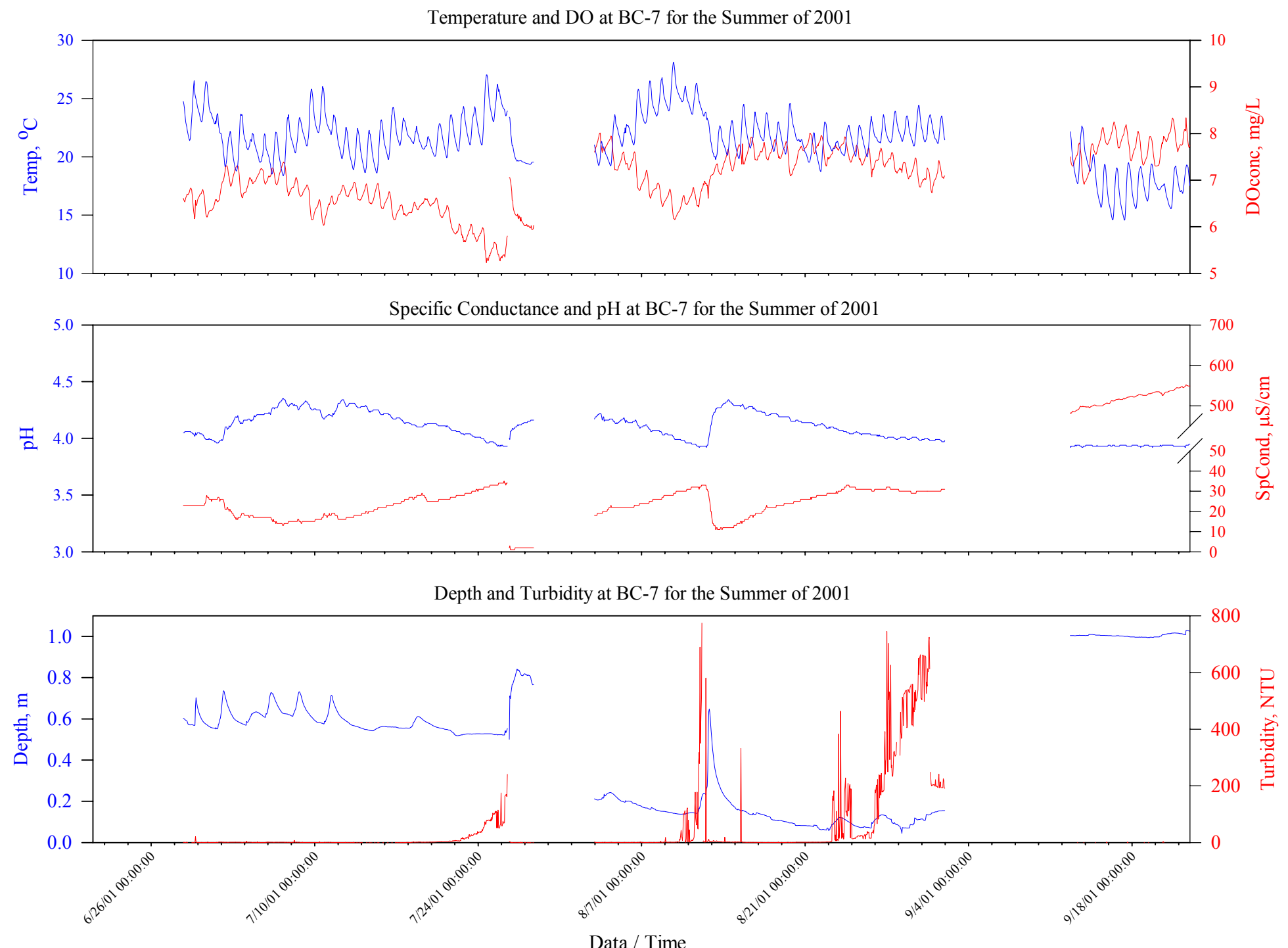

Figure A-12. Revised Sonde Data Collected During the Summer of 2001 at BC-7. 

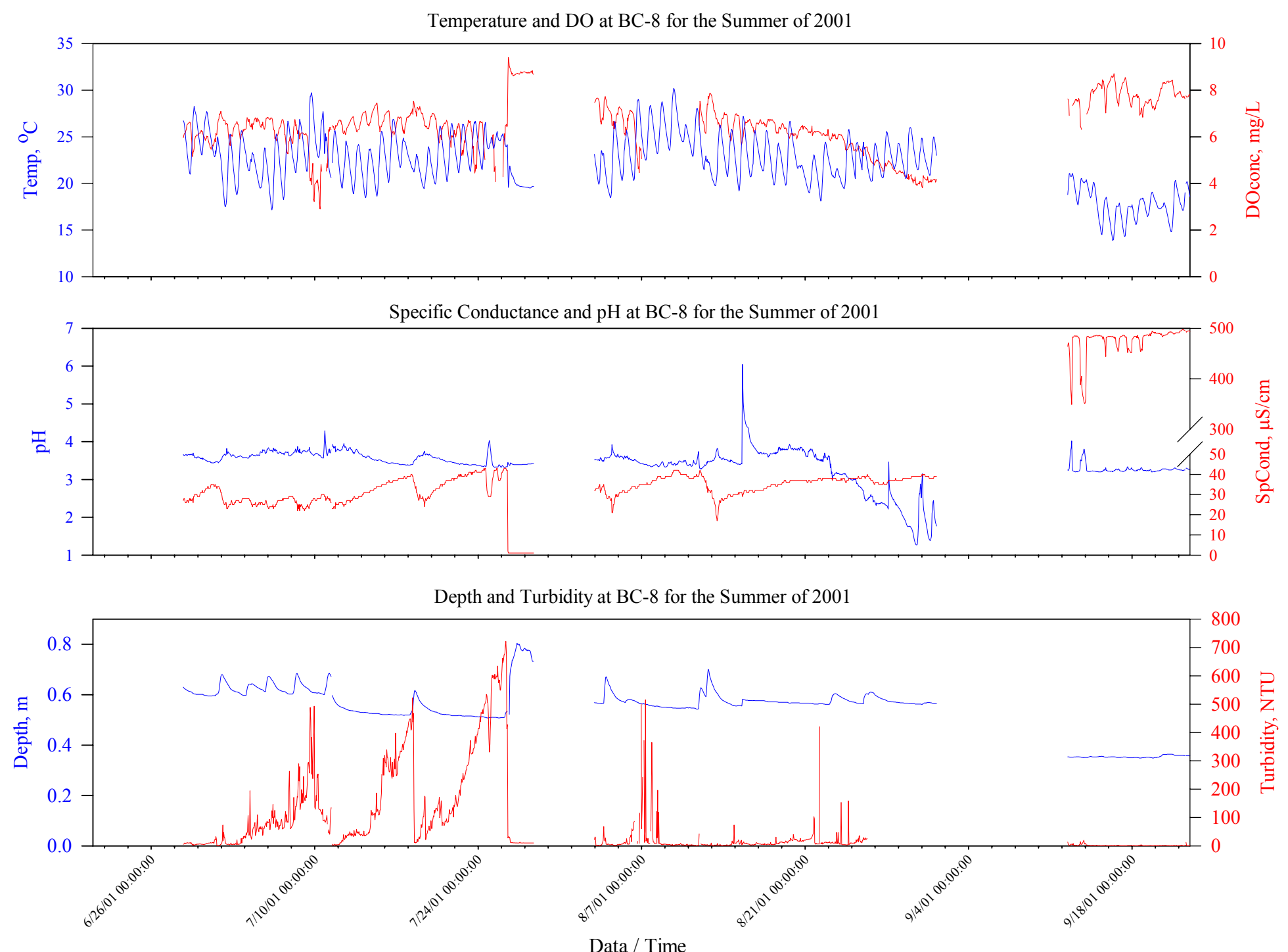

Figure A-13. Revised Sonde Data Collected During the Summer of 2001 at BC-8. 

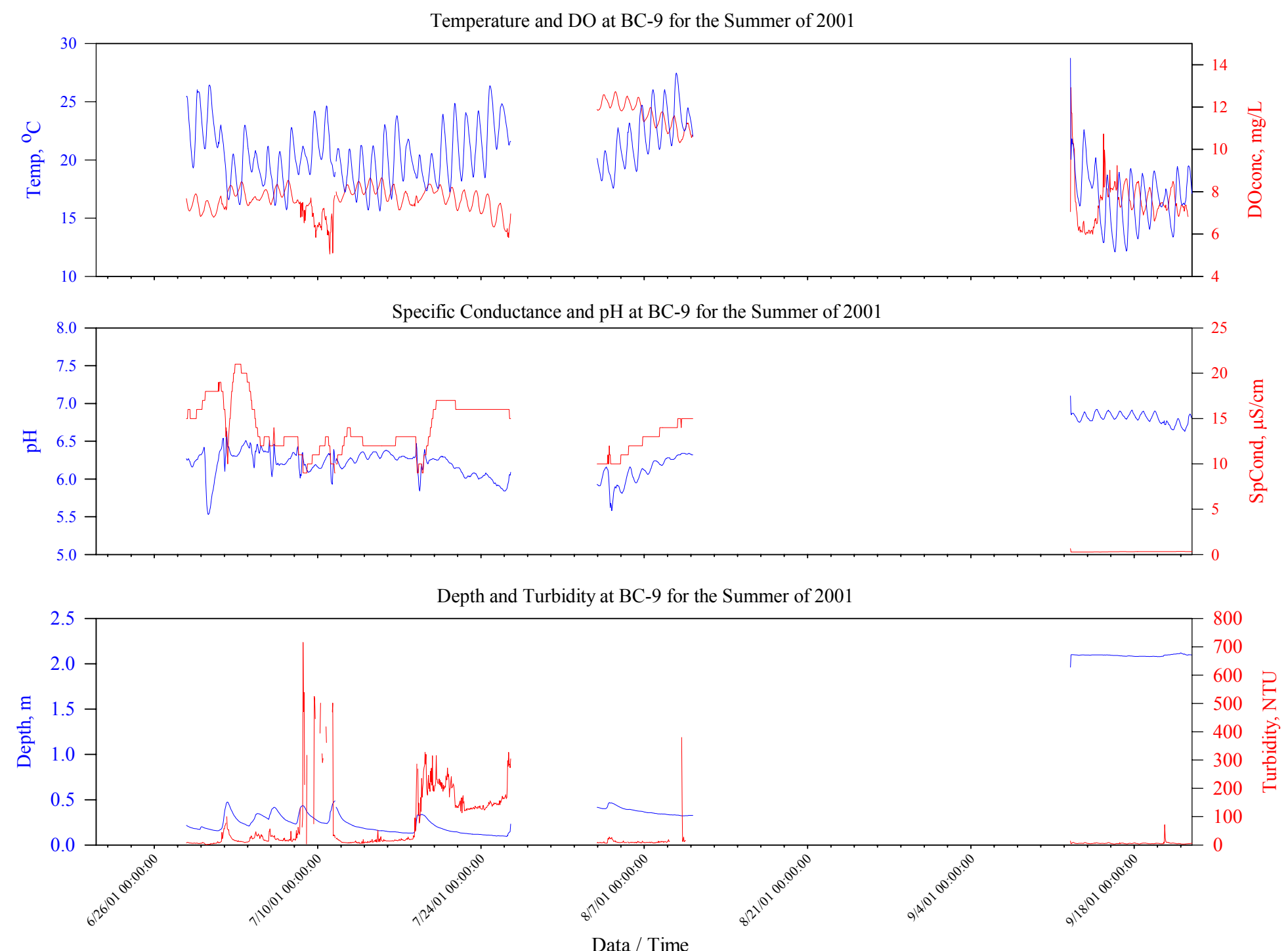

Figure A-14. Revised Sonde Data Collected During the Summer of 2001 at BC-9. 

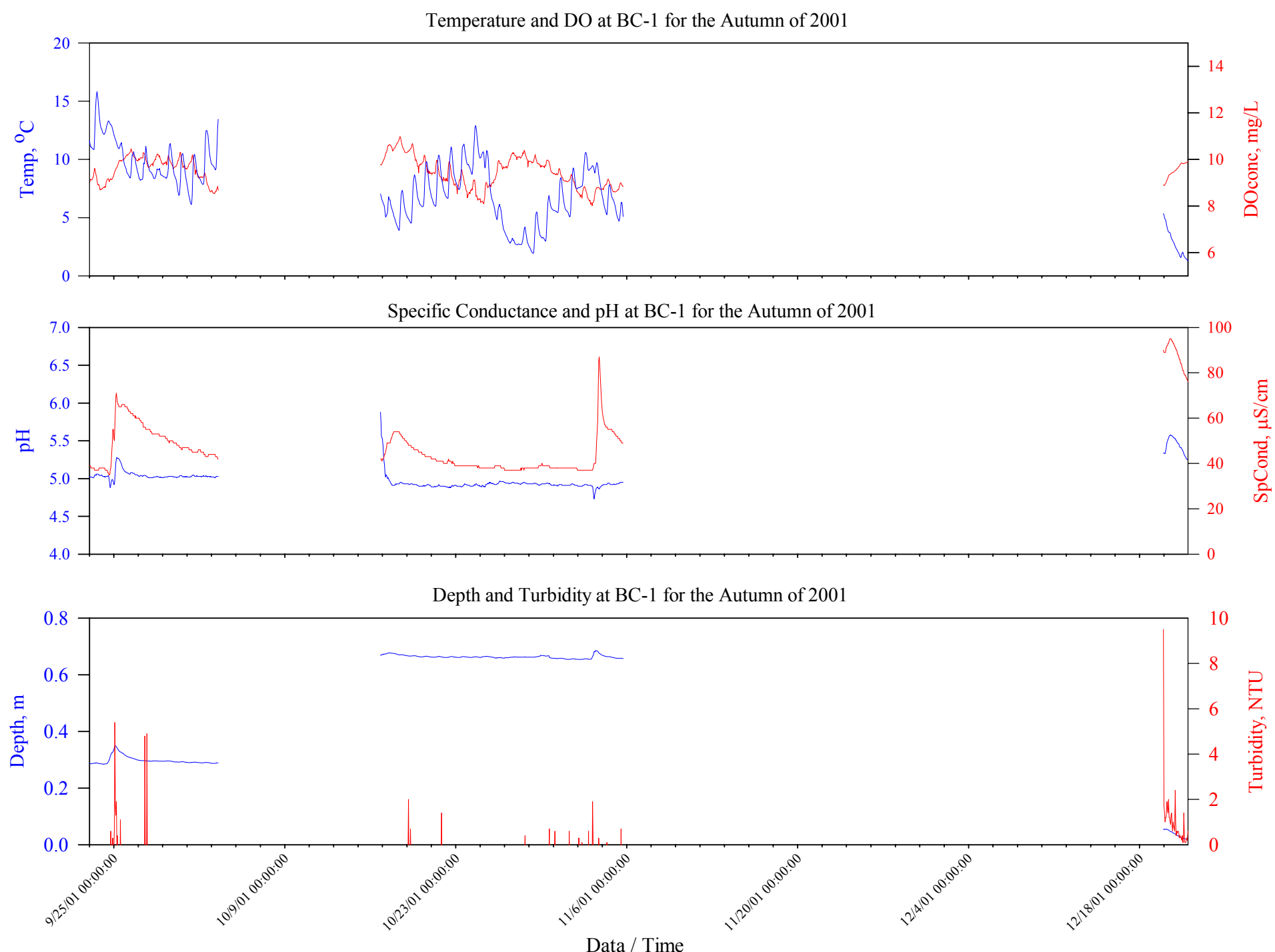

Figure A-15. Revised Sonde Data Collected During the Autumn of 2001 at BC-1. 
Temperature and DO at BC-3 for the Autumn of 2001
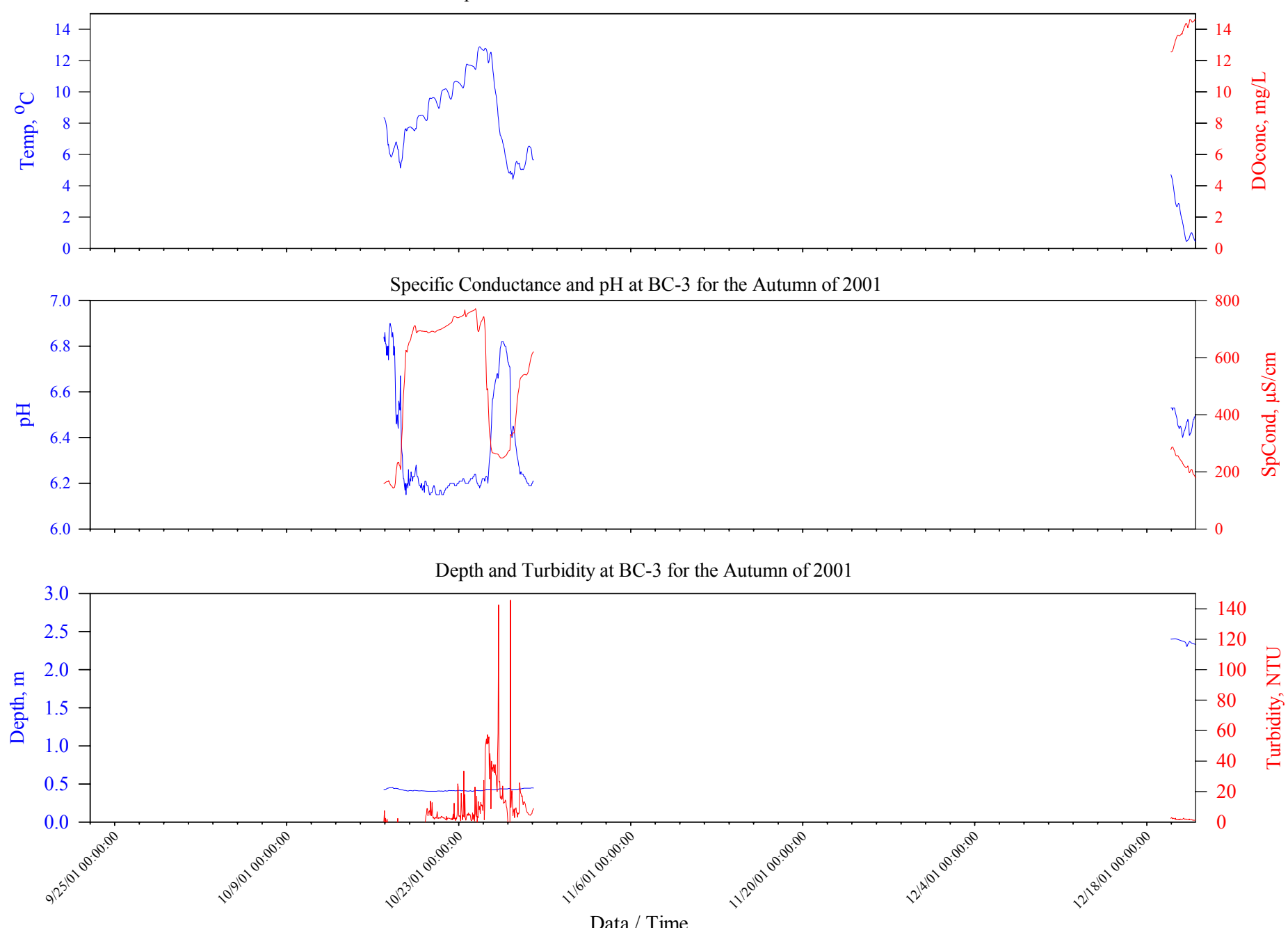

Figure A-16. Revised Sonde Data Collected During the Autumn of 2001 at BC-3. 

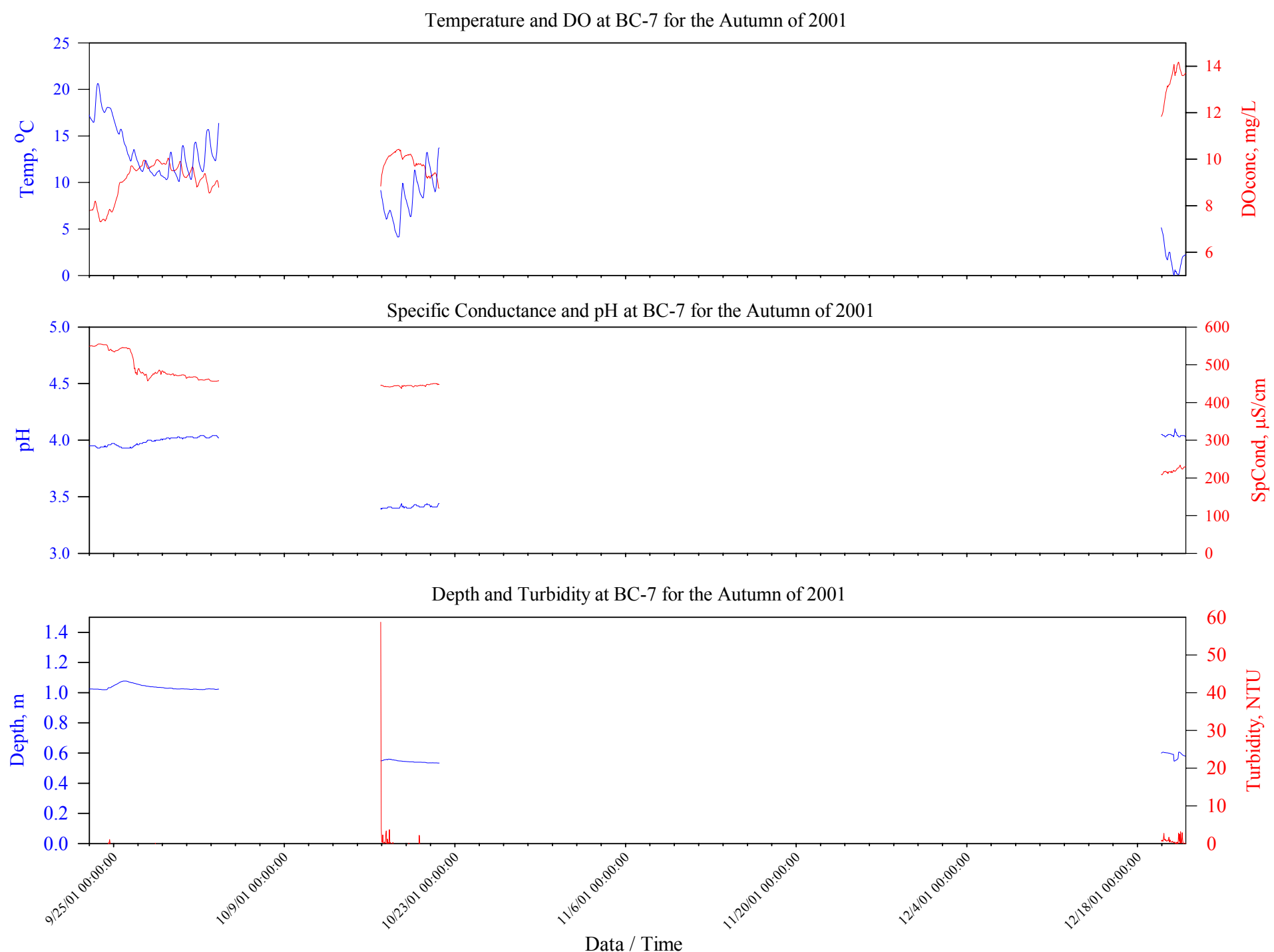

Figure A-17. Revised Sonde Data Collected During the Autumn of 2001 at BC-7. 

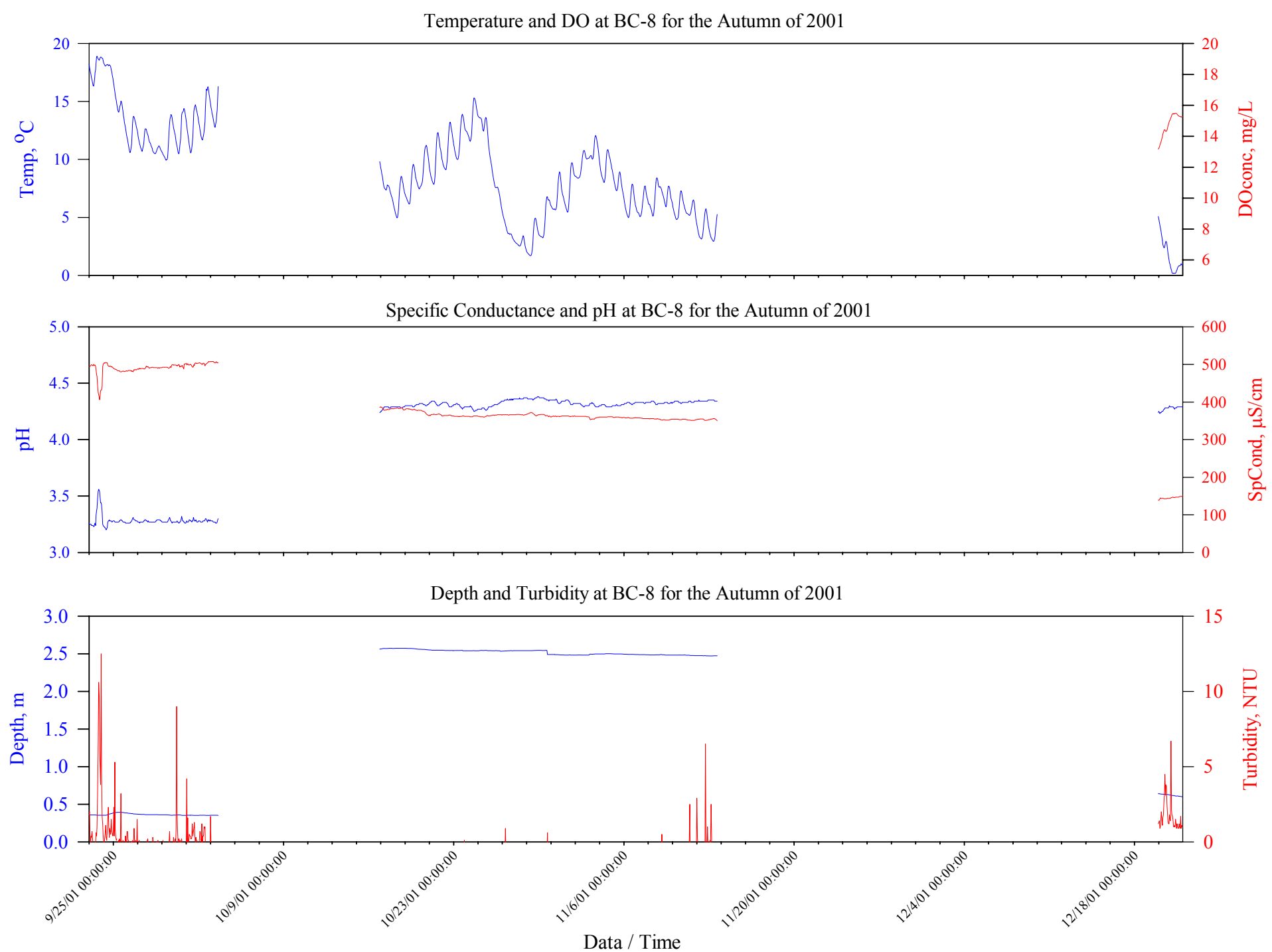

Figure A-18. Revised Sonde Data Collected During the Autumn of 2001 at BC-8. 

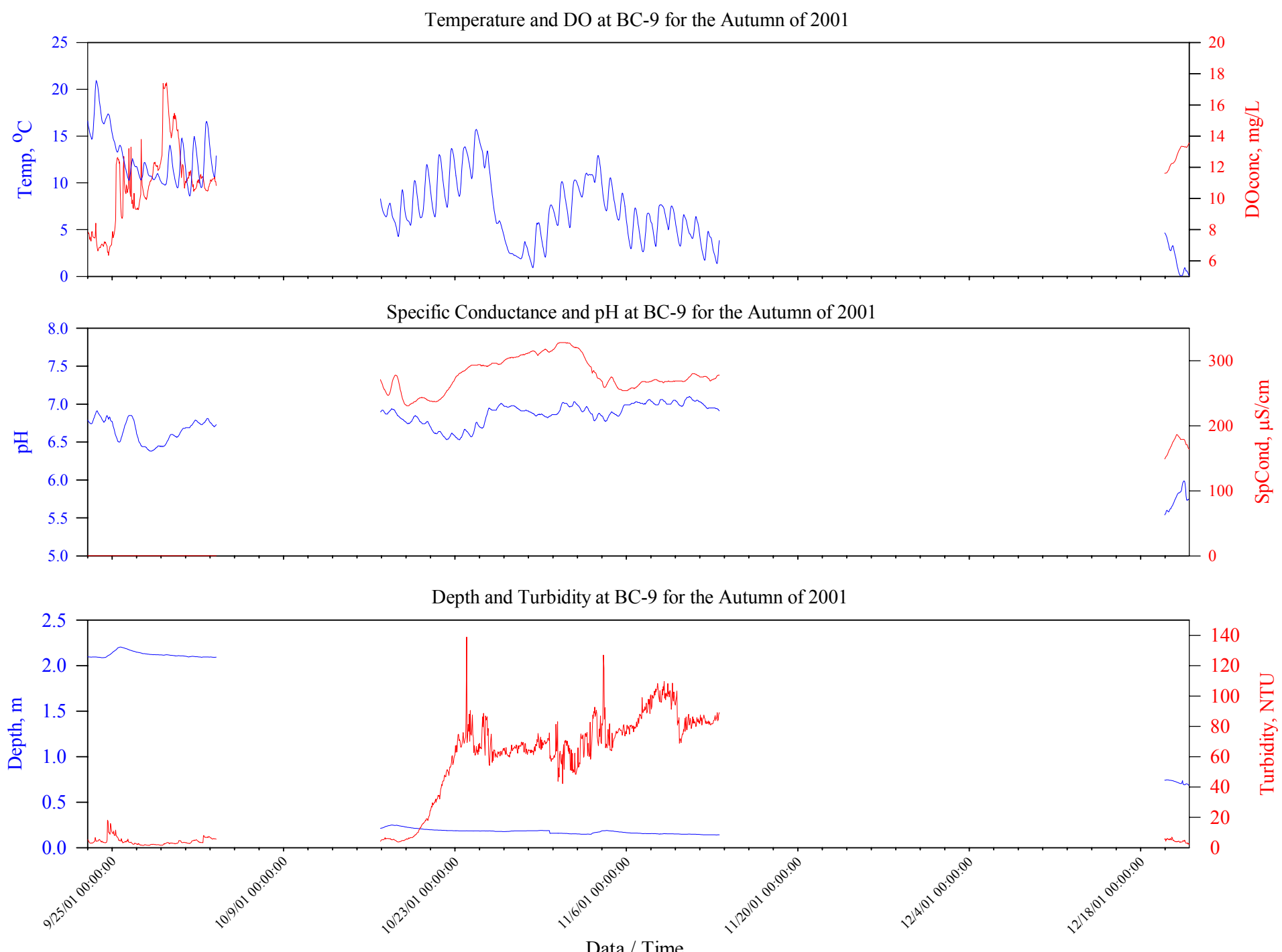

Figure A-19. Revised Sonde Data Collected During the Autumn of 2001 at BC-9. 

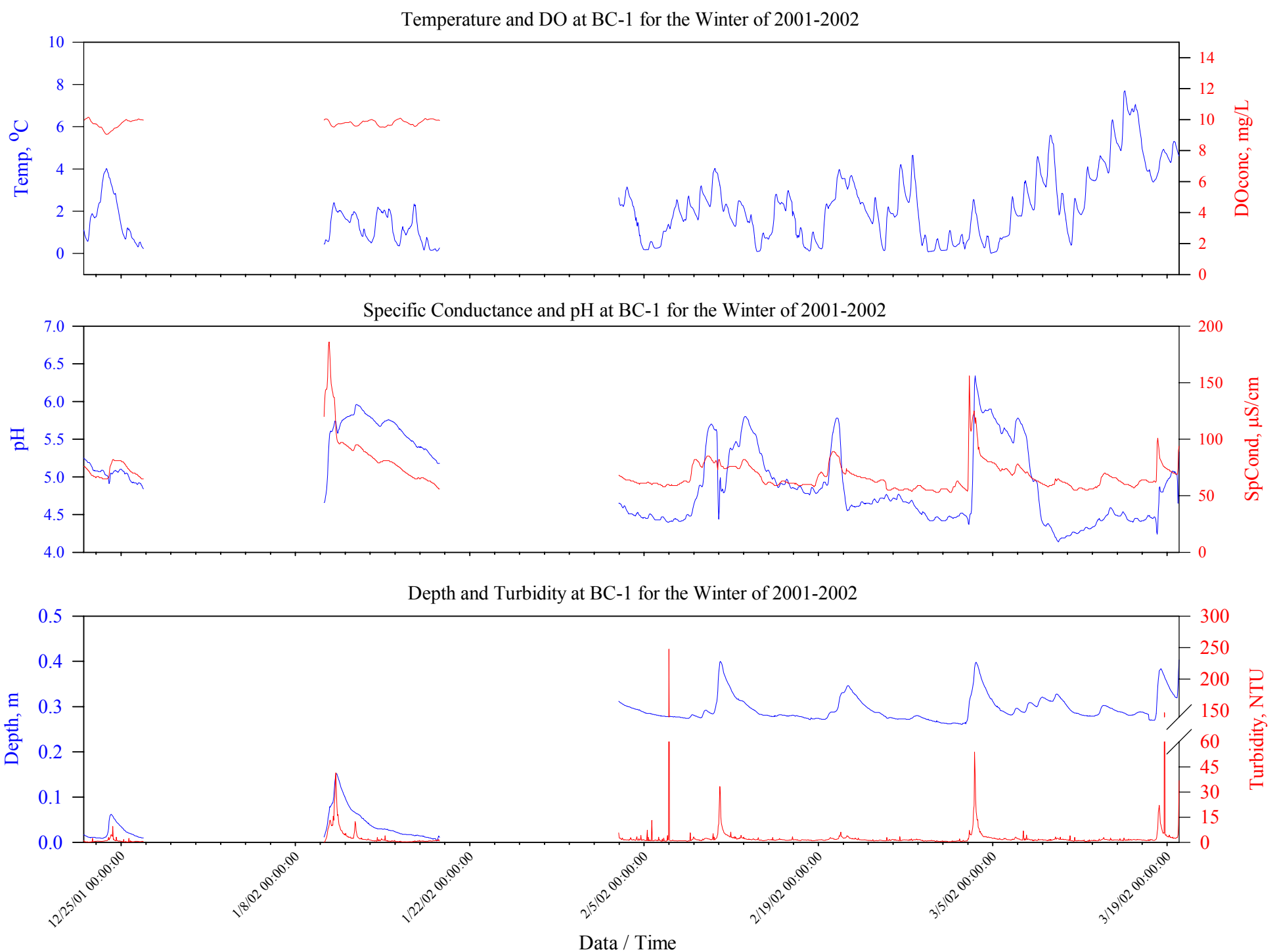

Figure A-20. Revised Sonde Data Collected During the Winter of 2001 and 2002 at BC-1. 

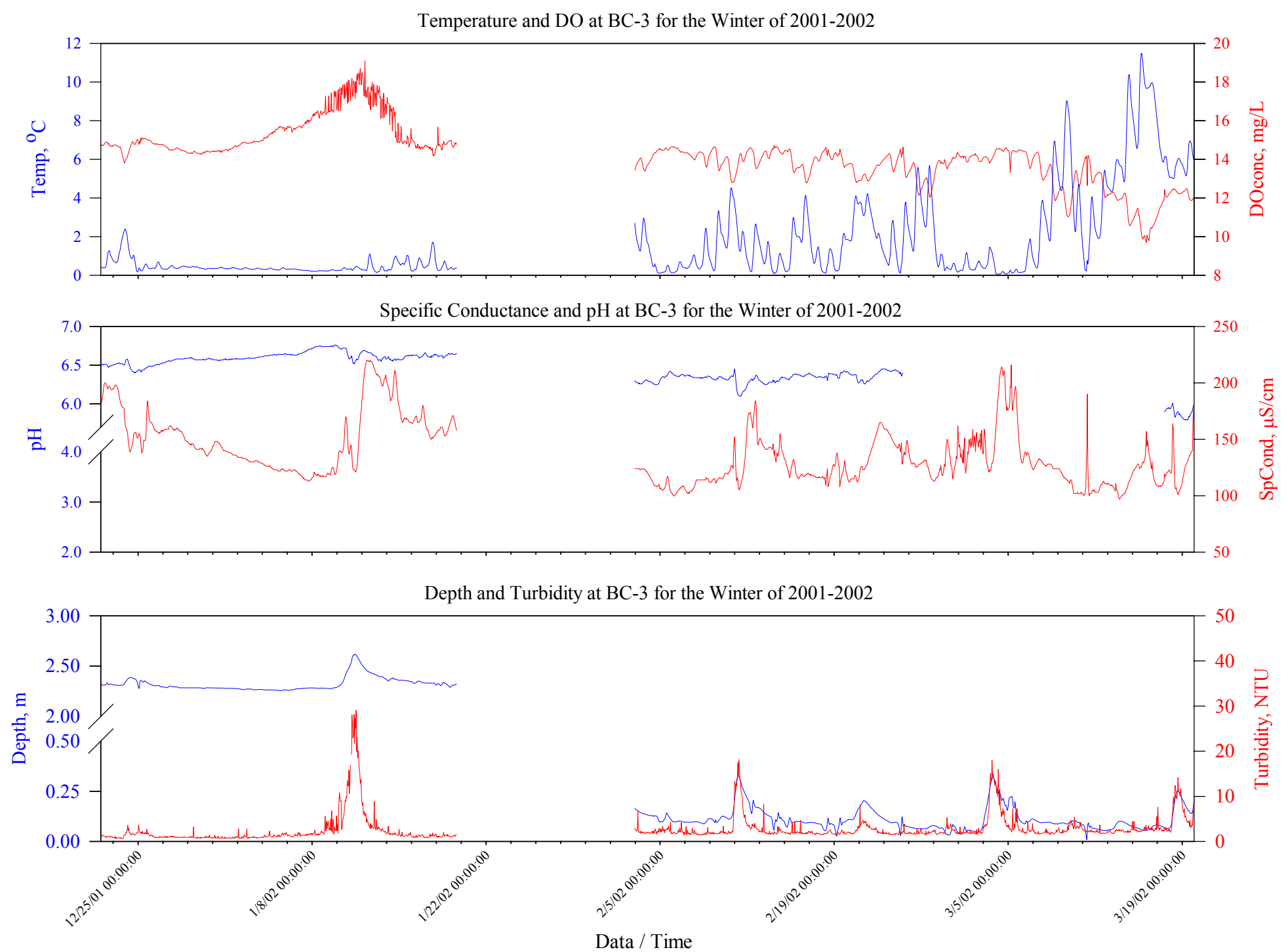

Figure A-21. Revised Sonde Data Collected During the Winter of 2001 to 2002 at BC-3. 

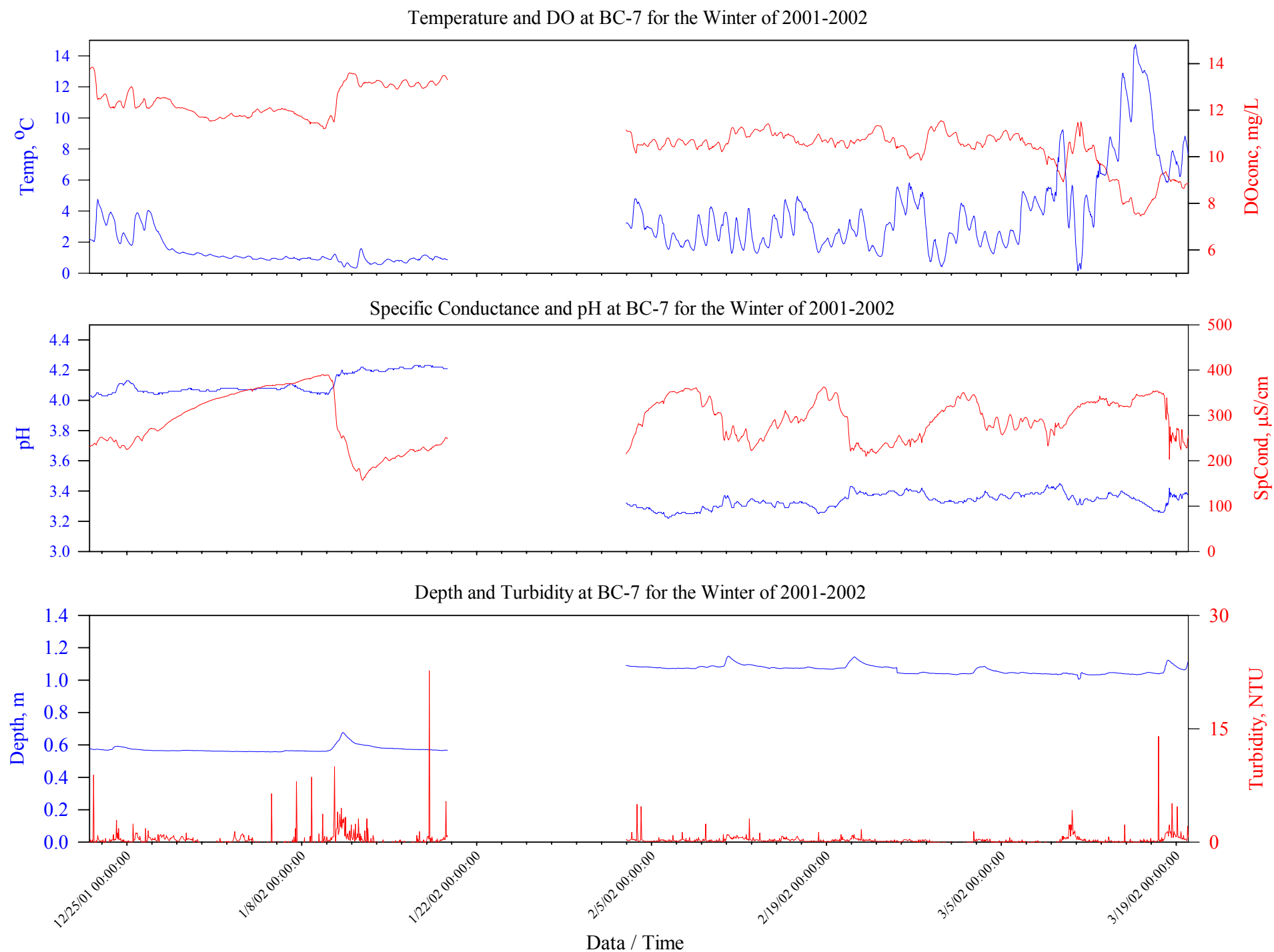

Figure A-22. Revised Sonde Data Collected During the Winter of 2001 to 2002 at BC-7. 

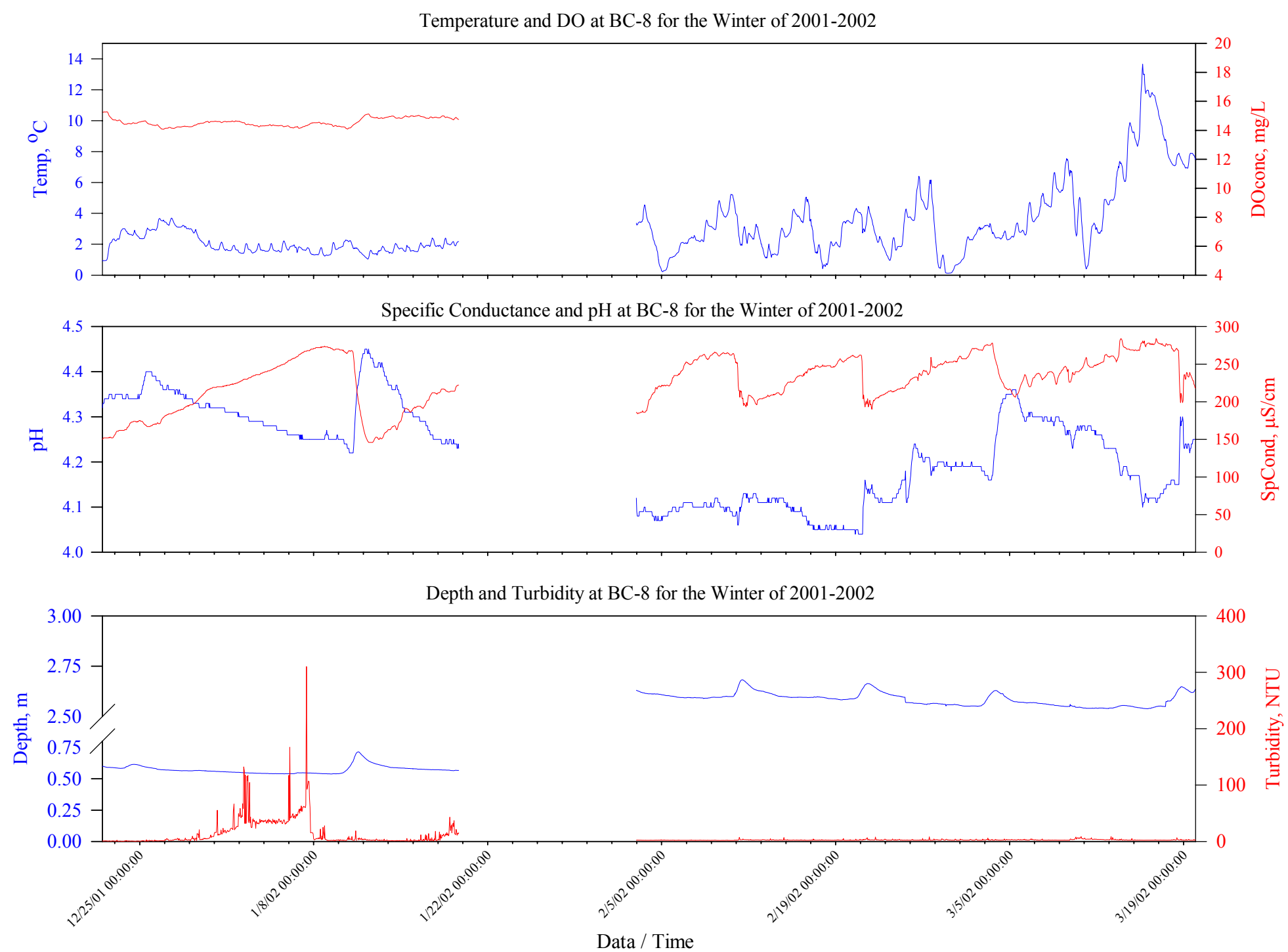

Figure A-23. Revised Sonde Data Collected During the Winter of 2001 to 2002 at BC-8. 

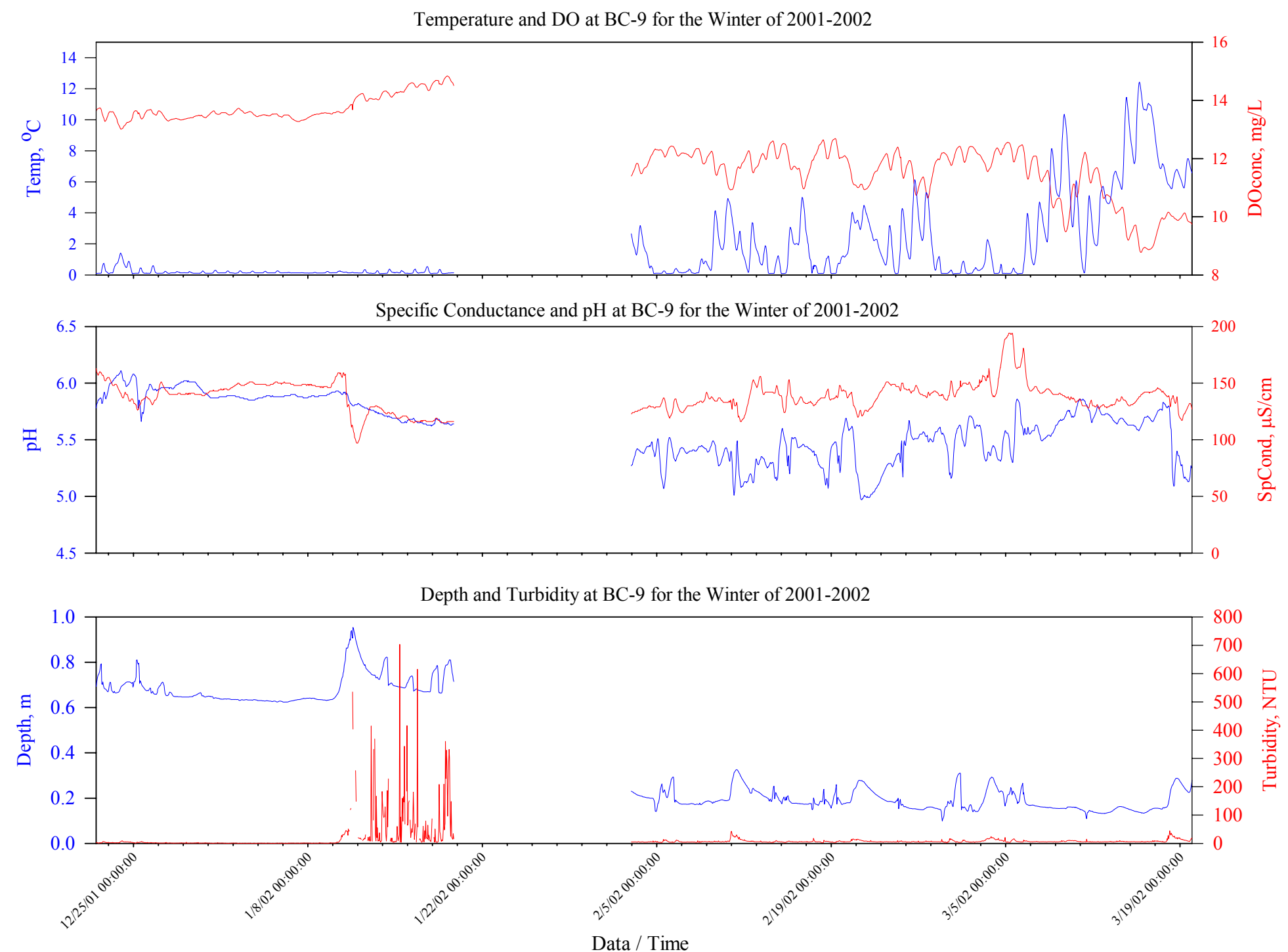

Figure A-24. Revised Sonde Data Collected During the Winter of 2001 to 2002 at BC-9. 

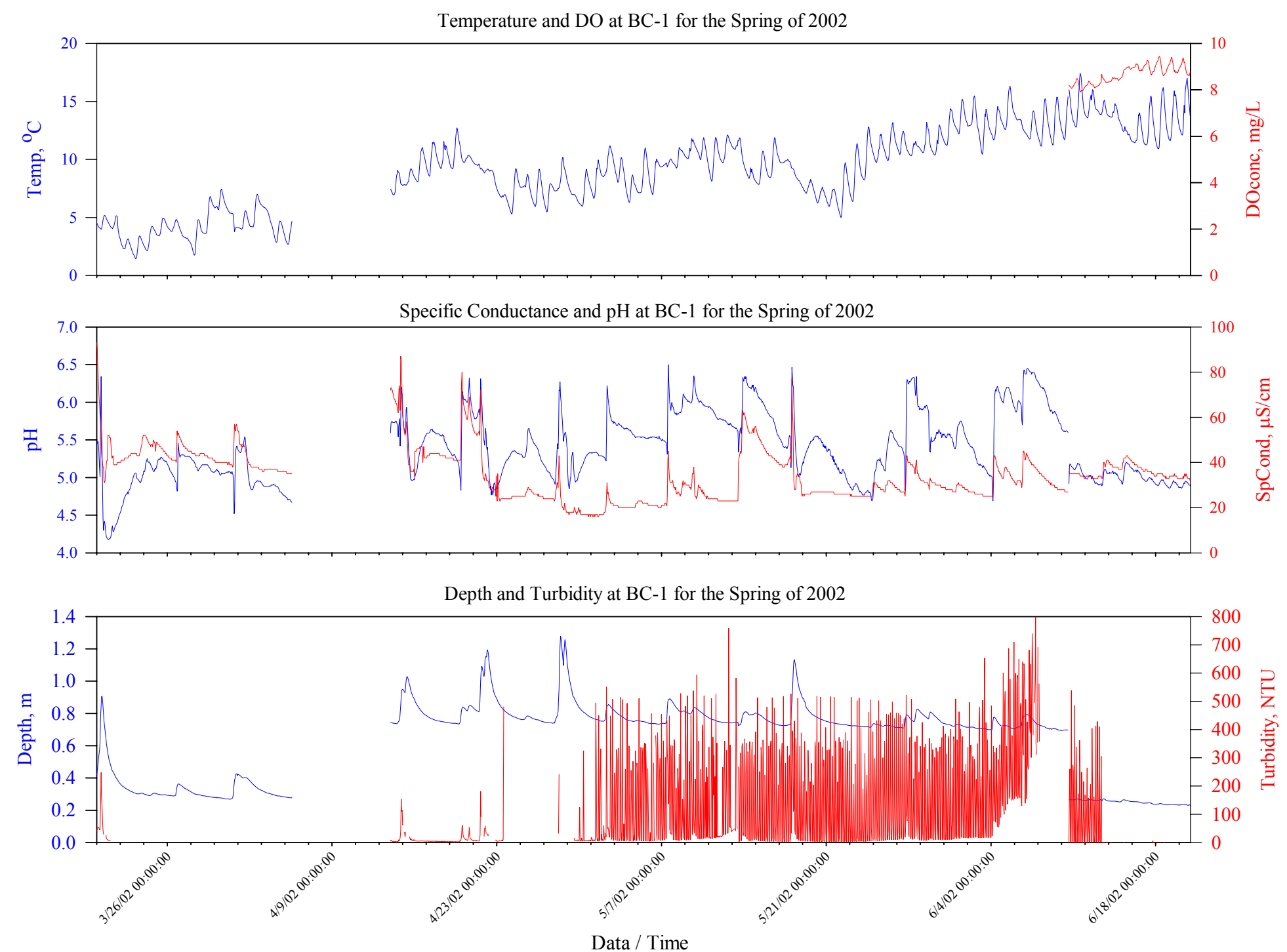

Figure A-25. Revised Sonde Data Collected During the Spring of 2002 at BC-1. 

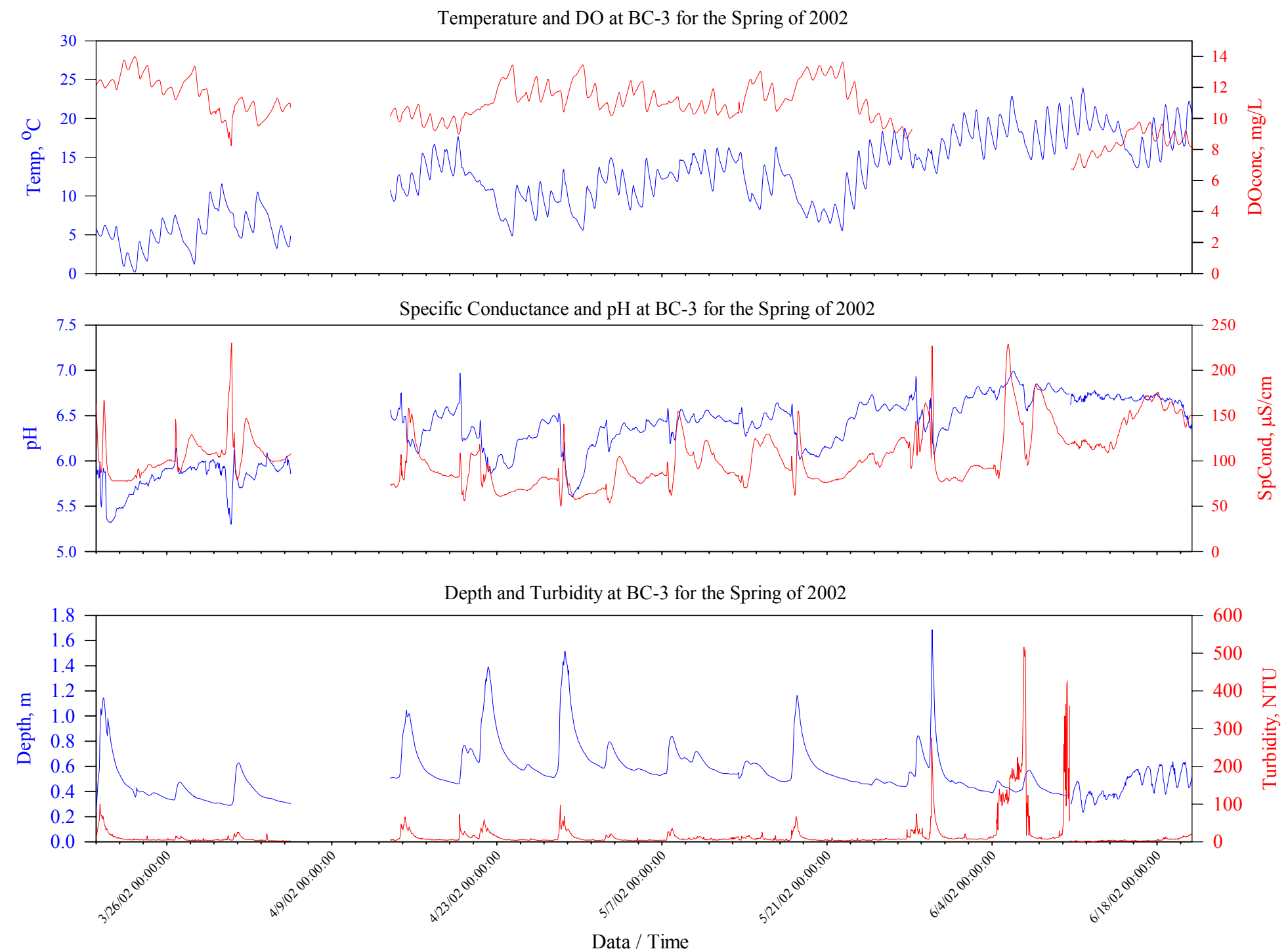

Figure A-26. Revised Sonde Data Collected During the Spring of 2002 at BC-3. 

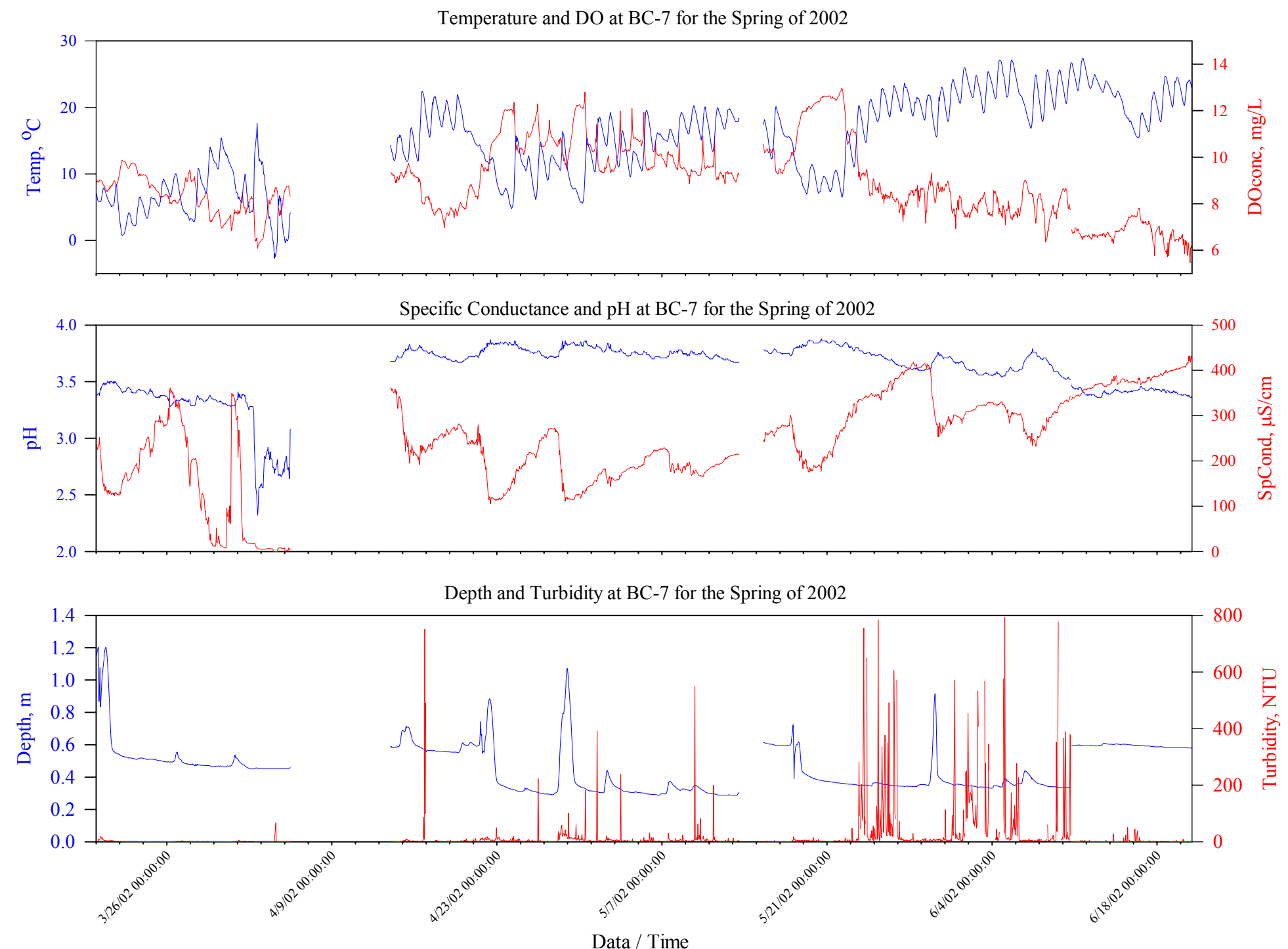

Figure A-27. Revised Sonde Data Collected During the Spring of 2002 at BC-7. 

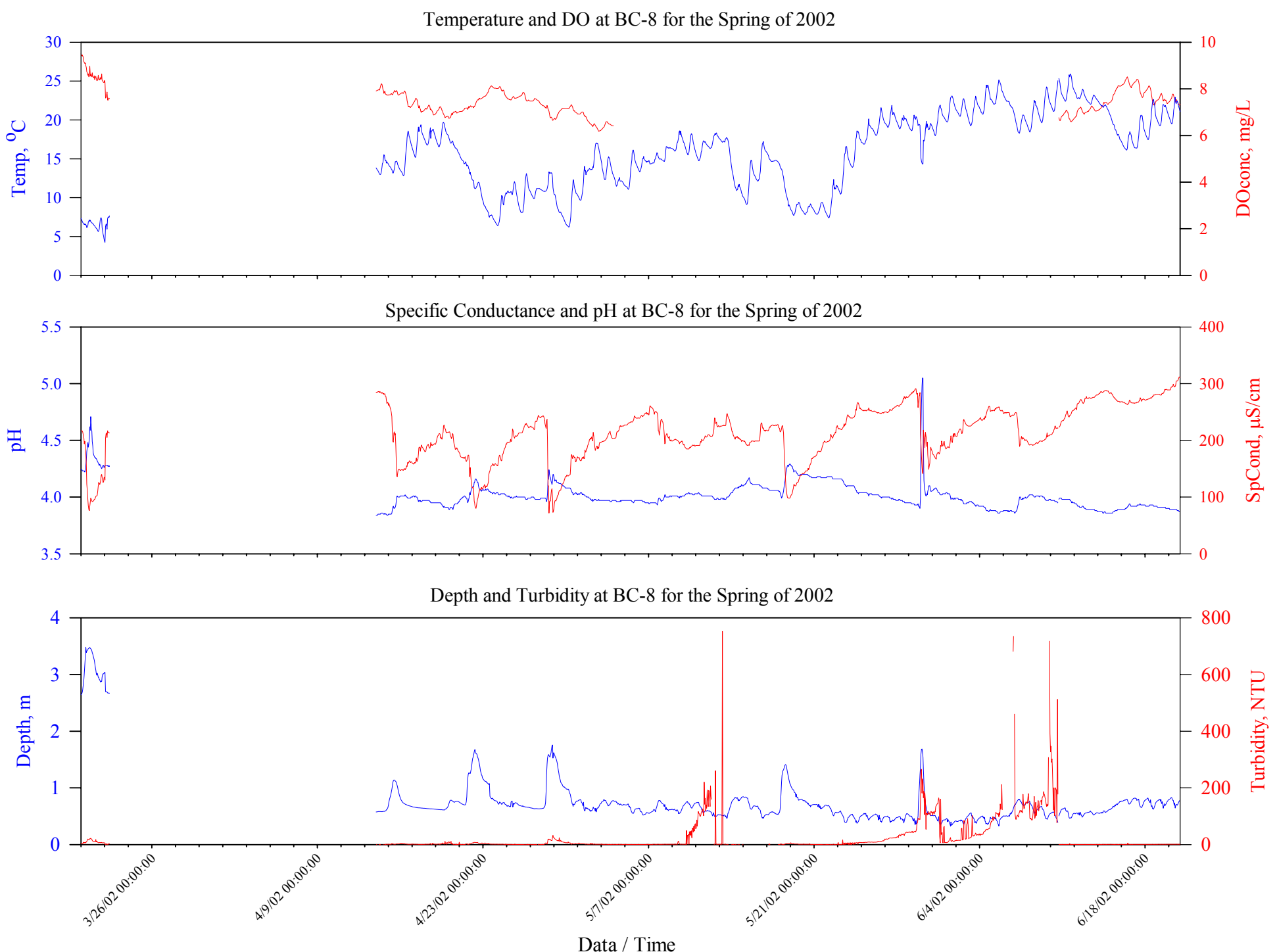

Figure A-28. Revised Sonde Data Collected During the Spring of 2002 at BC-8. 

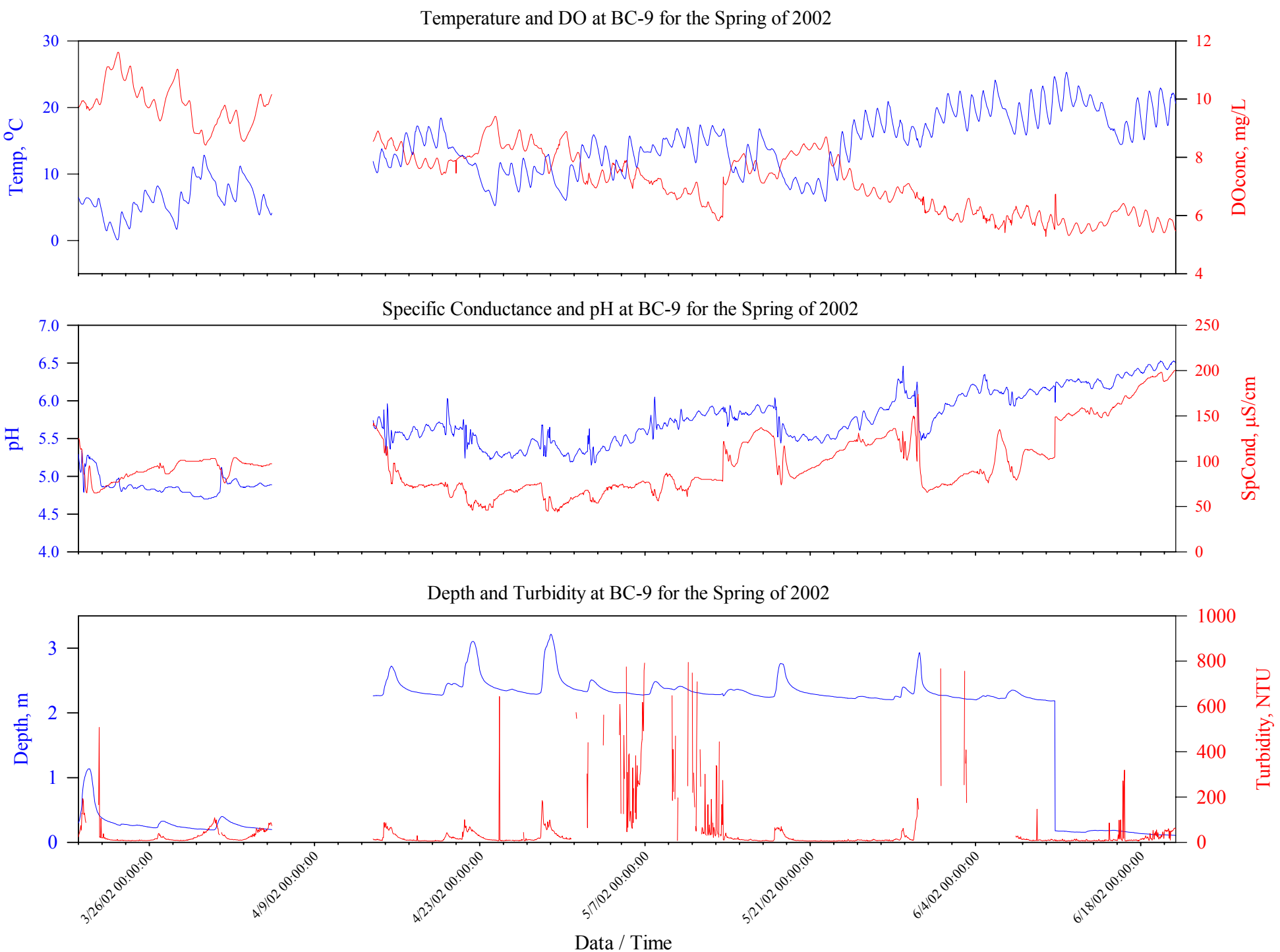

Figure A-29. Revised Sonde Data Collected During the Spring of 2002 at BC-9. 

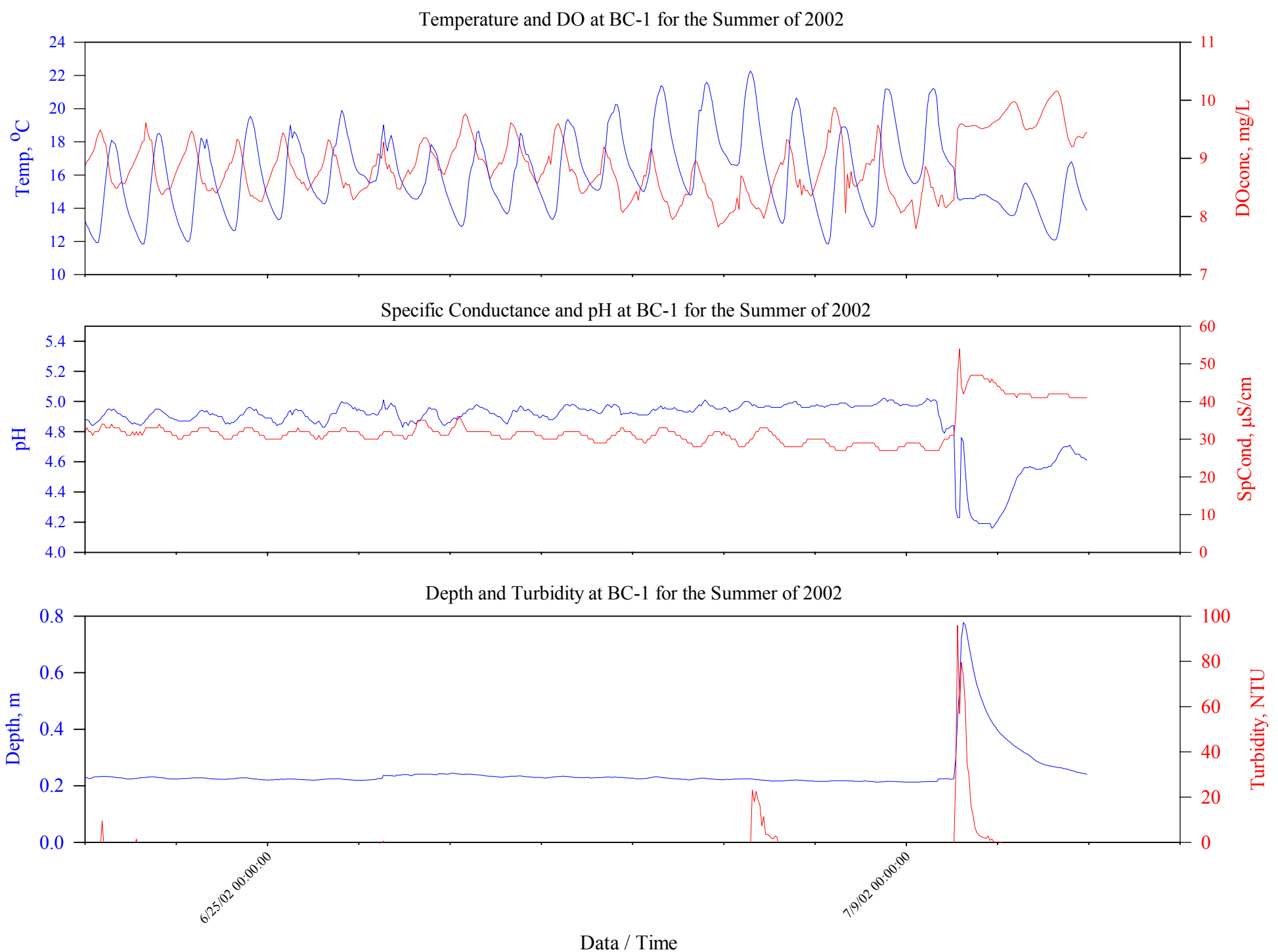

Figure A-30. Revised Sonde Data Collected During the Summer of 2002 at BC-1. 

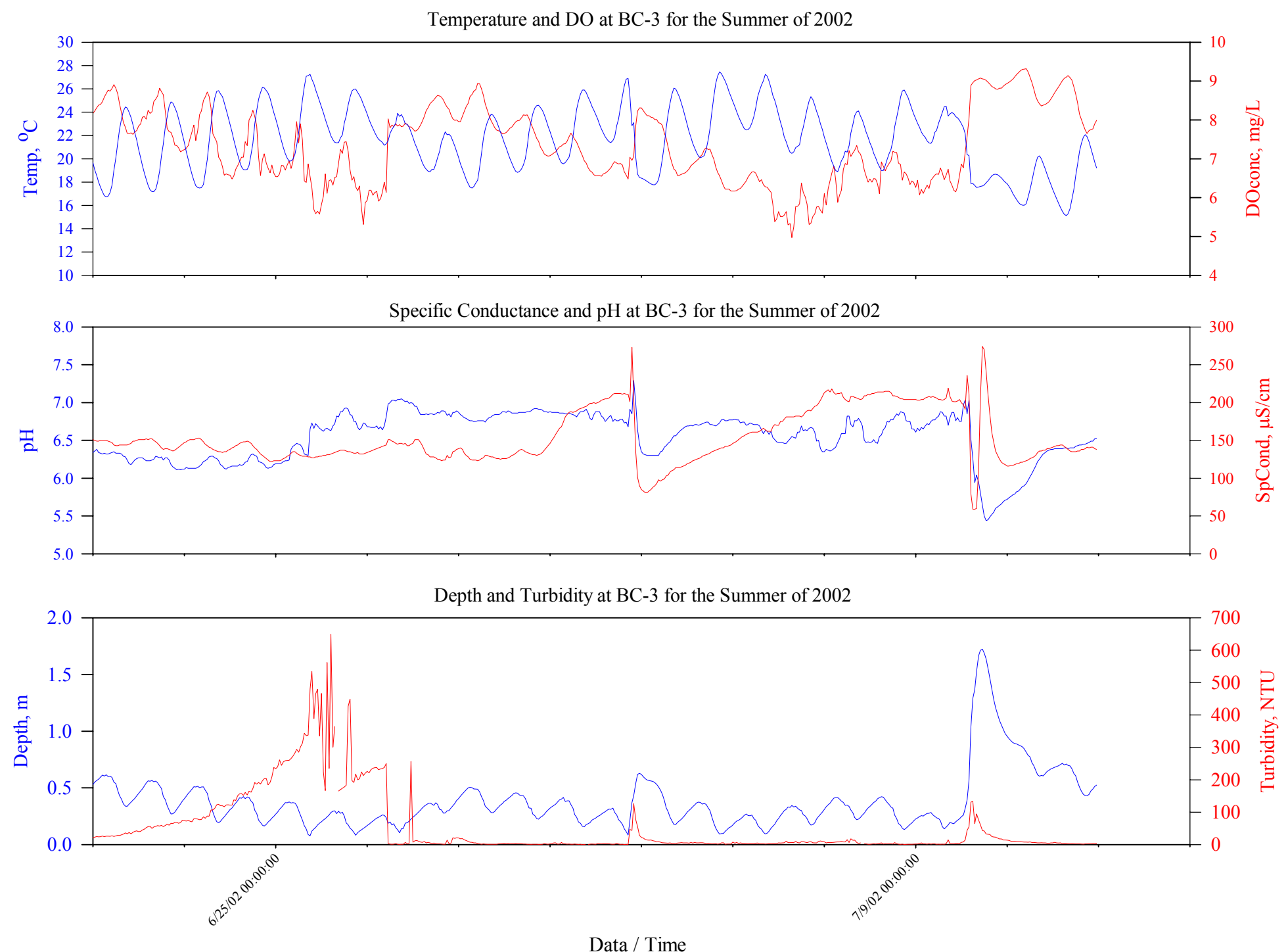

Figure A-31. Revised Sonde Data Collected During the Summer of 2002 at BC-3. 

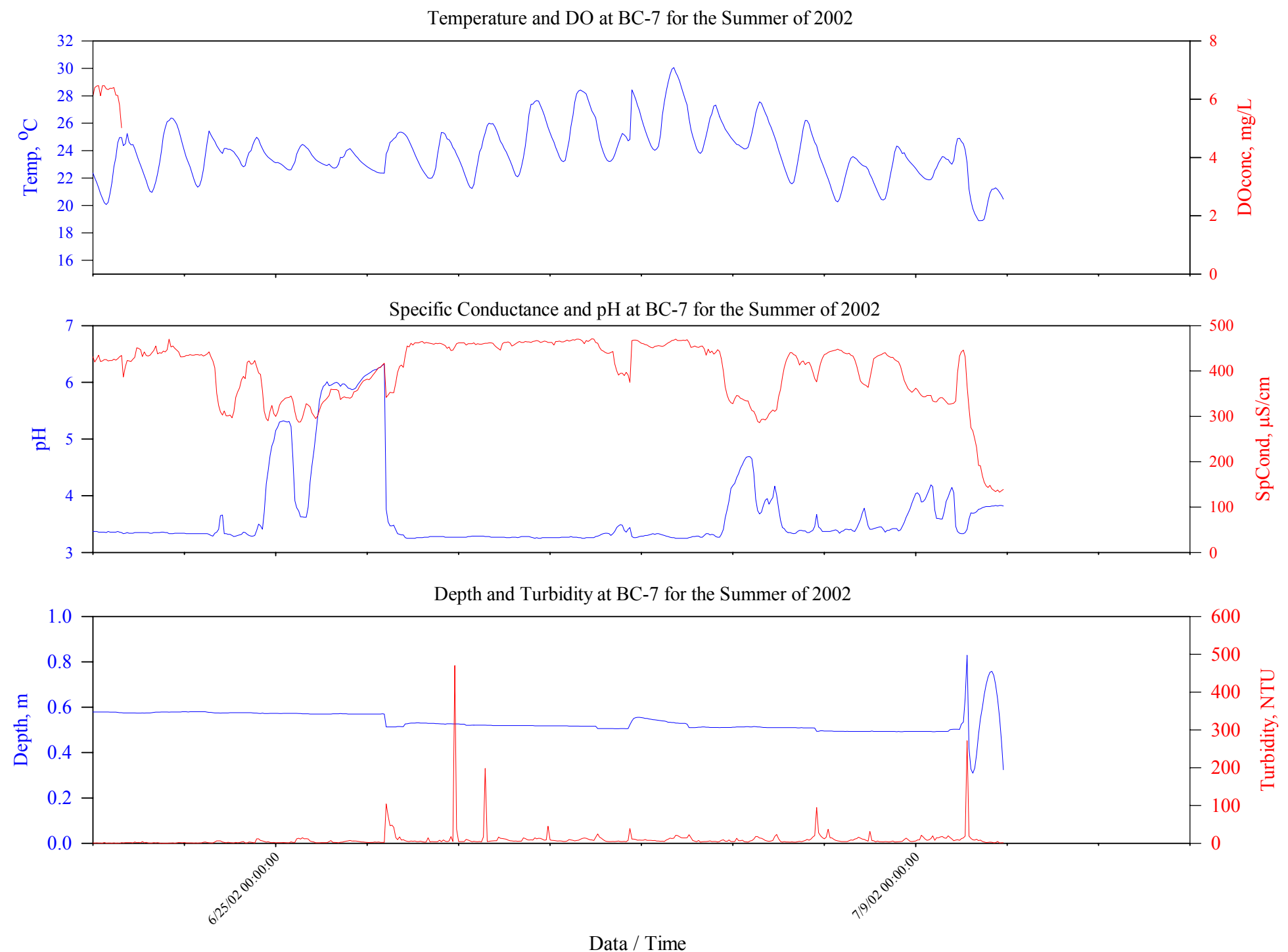

Figure A-32. Revised Sonde Data Collected During the Summer of 2002 at BC-7. 

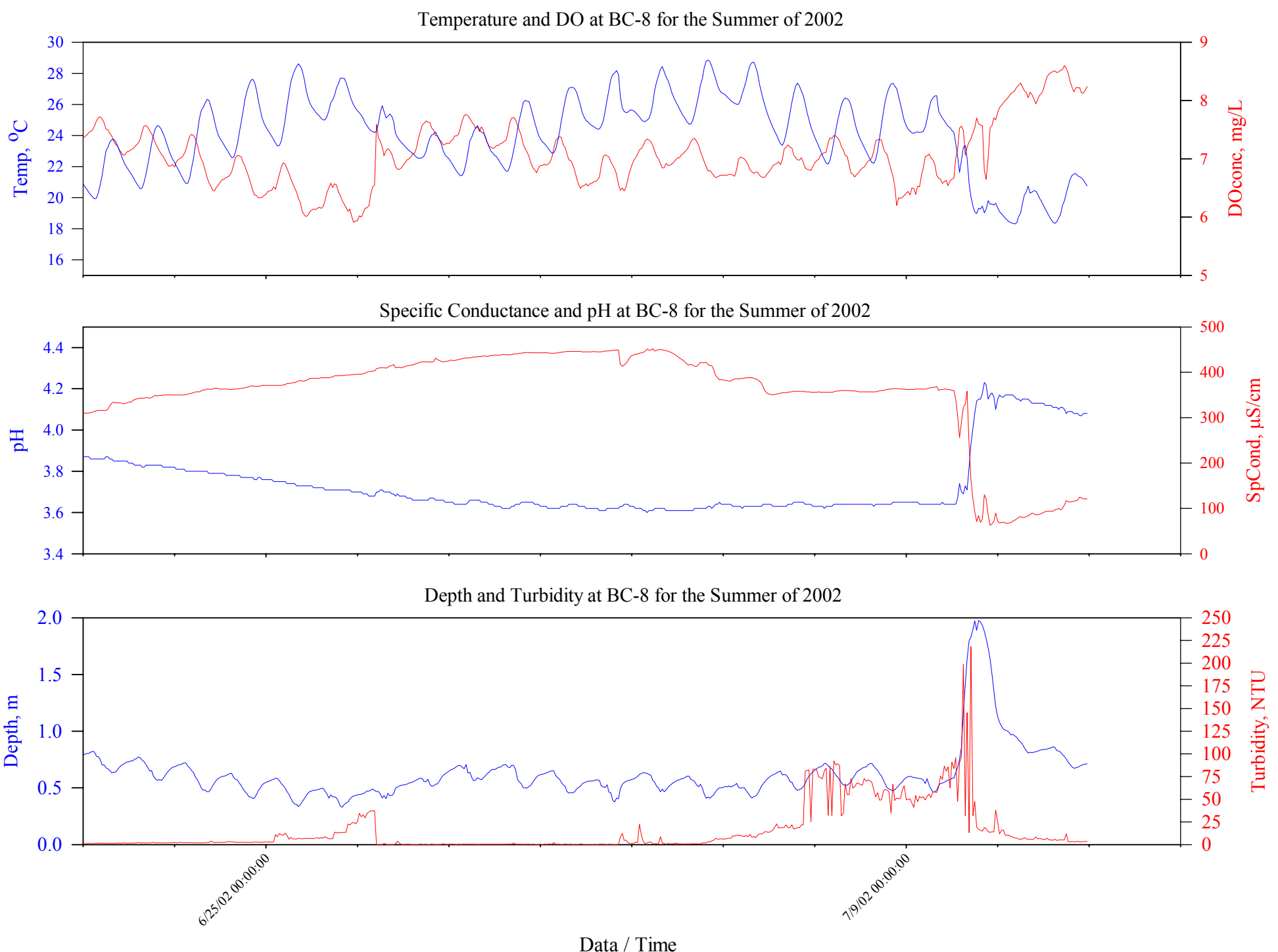

Figure A-33. Revised Sonde Data Collected During the Summer of 2002 at BC-8. 


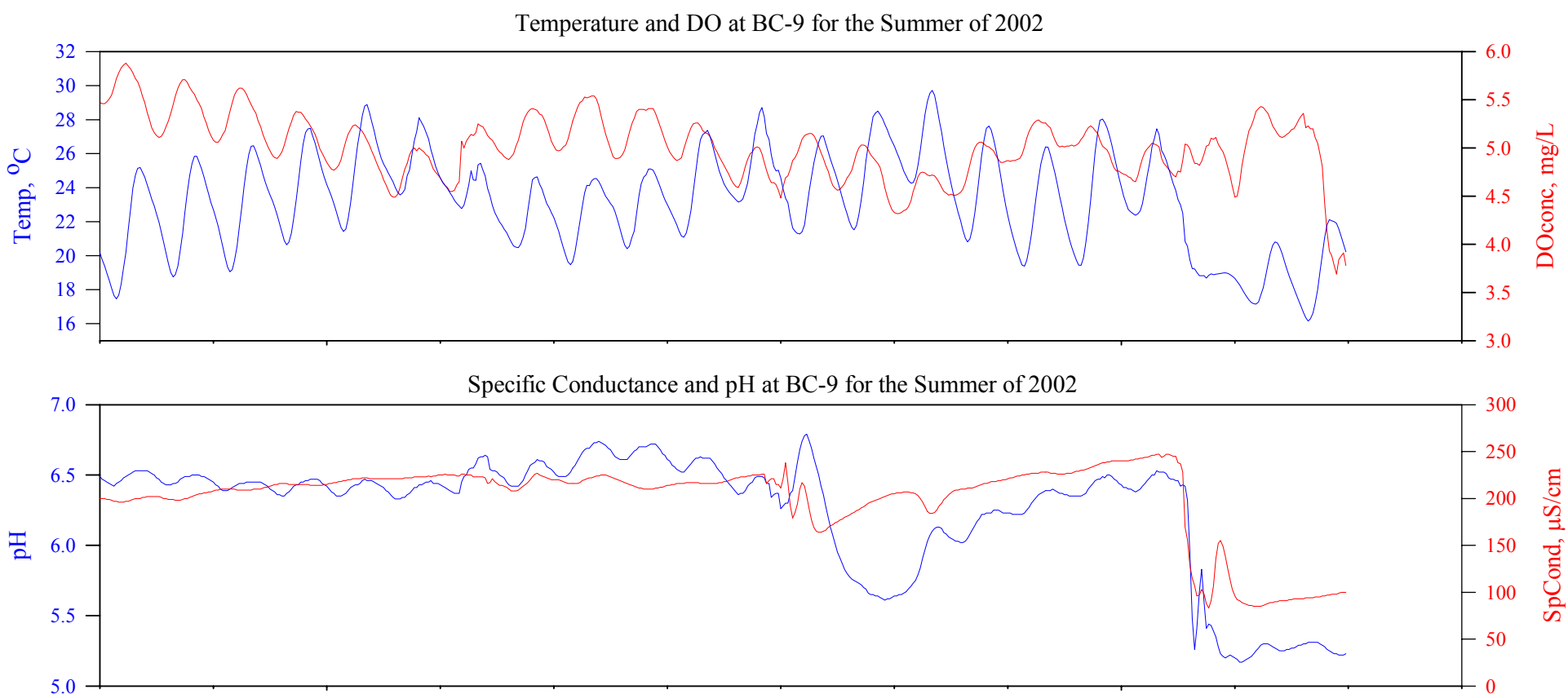

Depth and Turbidity at BC-9 for the Summer of 2002

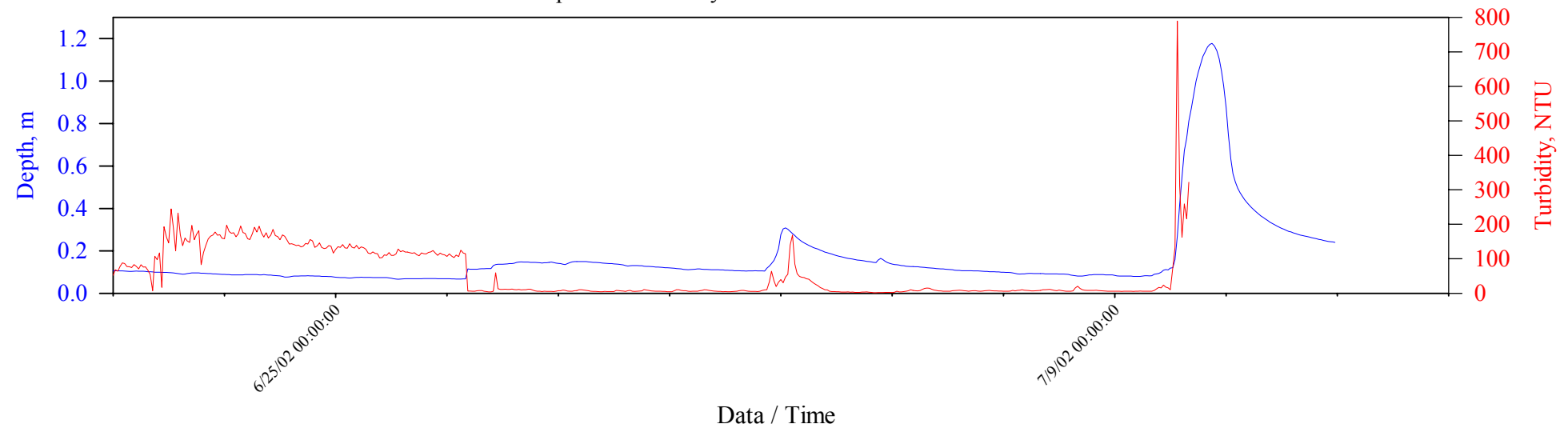

Figure A-34. Revised Sonde Data Collected During the Summer of 2002 at BC-9. 
APPENDIX B 
Table B-1a. Water Quality Grab Sample Data from BC-1.

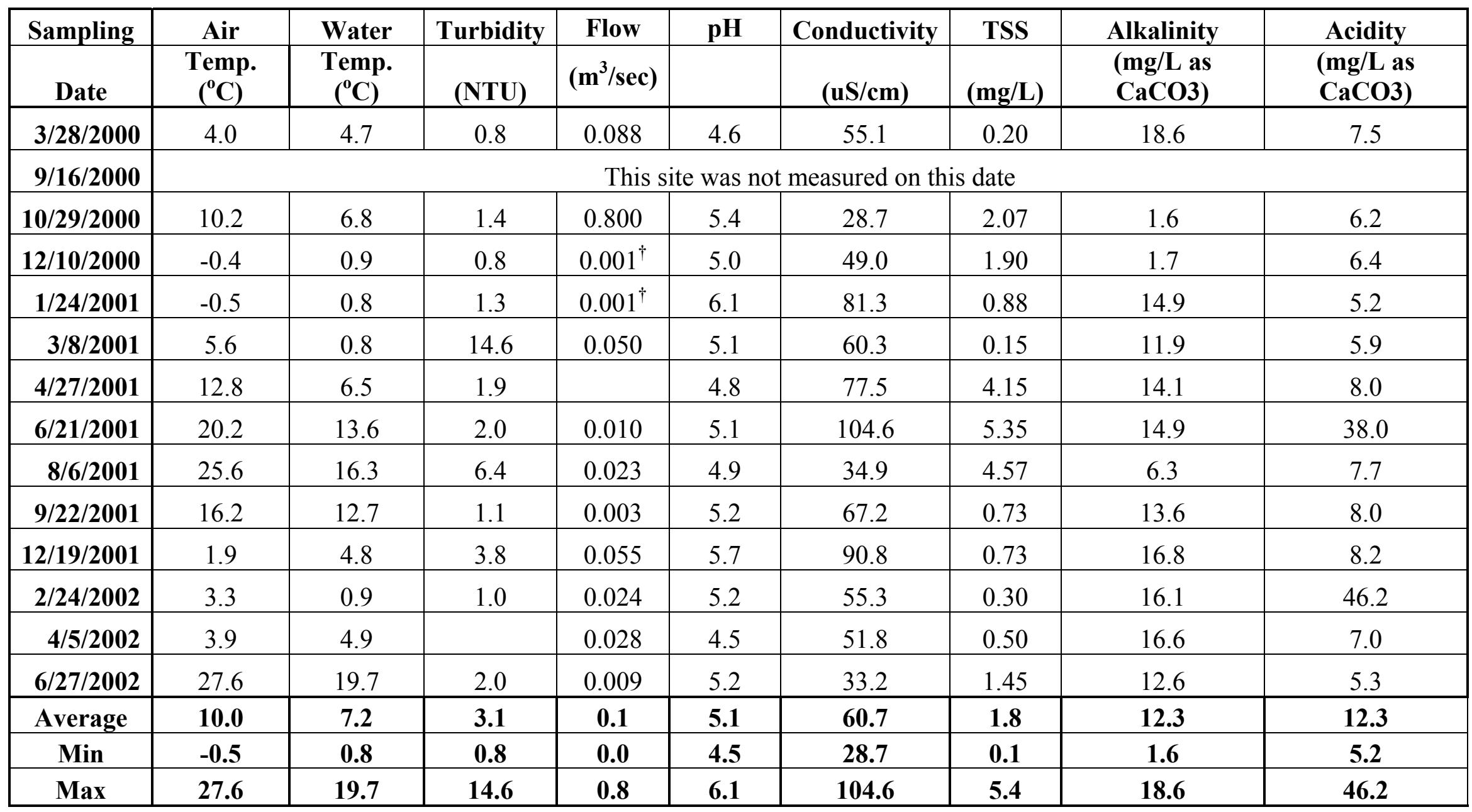

$\dagger$ Value Used for Below Detection Limit (BDL) is recorded as half of the Detection Limit Value

+ The Detection Limit Value for Chlorides before 5/10/2002 was equal to $1.00 \mathrm{mg} / \mathrm{L}$ for Mercuric Nitrate Buret Titration, Method 4500-CL- - C 
Table B-1b. Water Quality Grab Sample Data from BC-1.

\begin{tabular}{|c|c|c|c|c|c|c|c|c|c|c|c|}
\hline Sampling & Sulfate & Chloride & Iron & Calcium & Magnesium & Manganese & Aluminum & Nitrite & Nitrate & Ammonia & Phosphate \\
\hline Date & $(\mathrm{mg} / \mathrm{L})$ & $(\mathrm{mg} / \mathrm{L})$ & $(\mathrm{mg} / \mathrm{L})$ & $(\mathrm{mg} / \mathrm{L})$ & $(\mathrm{mg} / \mathrm{L})$ & $(\mathrm{mg} / \mathrm{L})$ & $(\mathrm{mg} / \mathrm{L})$ & $(\mathrm{mg} / \mathrm{L})$ & $(\mathrm{mg} / \mathrm{L})$ & $(\mathrm{mg} / \mathrm{L})$ & $(\mathrm{mg} / \mathrm{L})$ \\
\hline $3 / 28 / 2000$ & 8.0 & 6.1 & 0.2 & 11.2 & & & & $0.01^{\dagger}$ & $0.01^{\dagger}$ & $0.005^{\dagger}$ & 0.015 \\
\hline $9 / 16 / 2000$ & & 0.5 & & & & & & & & & \\
\hline $10 / 29 / 2000$ & $3.5^{\dagger}$ & 3.0 & 0.2 & 2.4 & 0.3 & $0.05^{\dagger}$ & 0.3 & $0.01^{\dagger}$ & 0.04 & 0.01 & $0.003^{\dagger}$ \\
\hline $12 / 10 / 2000$ & $3.5^{\dagger}$ & & $0.05^{\dagger}$ & 2.7 & $0.05^{\dagger}$ & 0.3 & 0.2 & $0.01^{\dagger}$ & 0.06 & $0.005^{\dagger}$ & 0.027 \\
\hline $1 / 24 / 2001$ & 14.4 & 14.5 & 0.2 & 19.0 & 0.6 & $0.005^{\dagger}$ & 0.3 & $0.01^{\dagger}$ & 0.07 & $0.005^{\dagger}$ & $0.003^{\dagger}$ \\
\hline 3/8/2001 & 8.2 & 9.0 & 0.2 & 2.9 & 0.5 & & 0.1 & $0.01^{\dagger}$ & 0.06 & $0.005^{\dagger}$ & $0.003^{\dagger}$ \\
\hline $4 / 27 / 2001$ & 8.6 & 4.5 & 0.2 & 2.3 & 0.4 & 0.1 & 8.0 & $0.01^{\dagger}$ & 0.04 & $0.005^{\dagger}$ & $0.003^{\dagger}$ \\
\hline $6 / 21 / 2001$ & 7.5 & 2.5 & 0.1 & 1.9 & 0.3 & 0.1 & 0.1 & $0.01^{\dagger}$ & 0.03 & $0.005^{\dagger}$ & $0.003^{\dagger}$ \\
\hline $8 / 6 / 2001$ & 11.2 & 3.7 & 0.3 & 1.6 & 0.2 & 0.0 & 0.3 & $0.01^{\dagger}$ & $0.01^{\dagger}$ & $0.005^{\dagger}$ & 0.005 \\
\hline $9 / 22 / 2001$ & 10.0 & 2.5 & 0.2 & 1.4 & 0.4 & 0.0 & 0.0 & $0.01^{\dagger}$ & $0.01^{\dagger}$ & $0.005^{\dagger}$ & 0.001 \\
\hline $12 / 19 / 2001$ & 23.6 & 6.5 & 0.3 & 7.8 & 0.9 & 0.0 & 0.4 & $0.01^{\dagger}$ & 0.05 & $0.005^{\dagger}$ & $0.003^{\dagger}$ \\
\hline $2 / 24 / 2002$ & 12.6 & 21.7 & 0.2 & 4.1 & 0.6 & 0.1 & 0.3 & $0.01^{\dagger}$ & 0.02 & $0.005^{\dagger}$ & $0.003^{\dagger}$ \\
\hline 4/5/2002 & 12.3 & 5.0 & 0.3 & 2.9 & 0.4 & 0.1 & 0.5 & $0.01^{\dagger}$ & 0.03 & $0.005^{\dagger}$ & $0.003^{\dagger}$ \\
\hline $6 / 27 / 2002$ & 10.1 & 2.8 & 0.2 & 1.9 & 0.4 & 0.0 & 0.3 & $0.01^{\dagger}$ & 0.02 & $0.005^{\dagger}$ & $0.003^{\dagger}$ \\
\hline Average & 11.5 & 6.3 & 0.2 & 4.8 & 0.5 & 0.1 & 0.9 & 0.01 & $\mathbf{0 . 0}$ & $\mathbf{0 . 0}$ & 0.0 \\
\hline Min & 7.5 & 0.5 & 0.1 & 1.4 & 0.2 & 0.0 & $\mathbf{0 . 0}$ & 0.01 & $\mathbf{0 . 0}$ & $\mathbf{0 . 0}$ & 0.0 \\
\hline Max & 23.6 & 21.7 & 0.3 & 19.0 & 0.9 & 0.3 & 8.0 & 0.01 & 0.1 & $\mathbf{0 . 0}$ & $\mathbf{0 . 0}$ \\
\hline
\end{tabular}

$\dagger$ Value Used for Below Detection Limit (BDL) is recorded as half of the Detection Limit Value

* The Detection Limit Value for Chlorides before 5/10/2002 was equal to $1.00 \mathrm{mg} / \mathrm{L}$ for Mercuric Nitrate Buret Titration, Method 4500-CL ${ }^{-}$- C 
Table B-2a. Water Quality Grab Sample Data from BC-2.

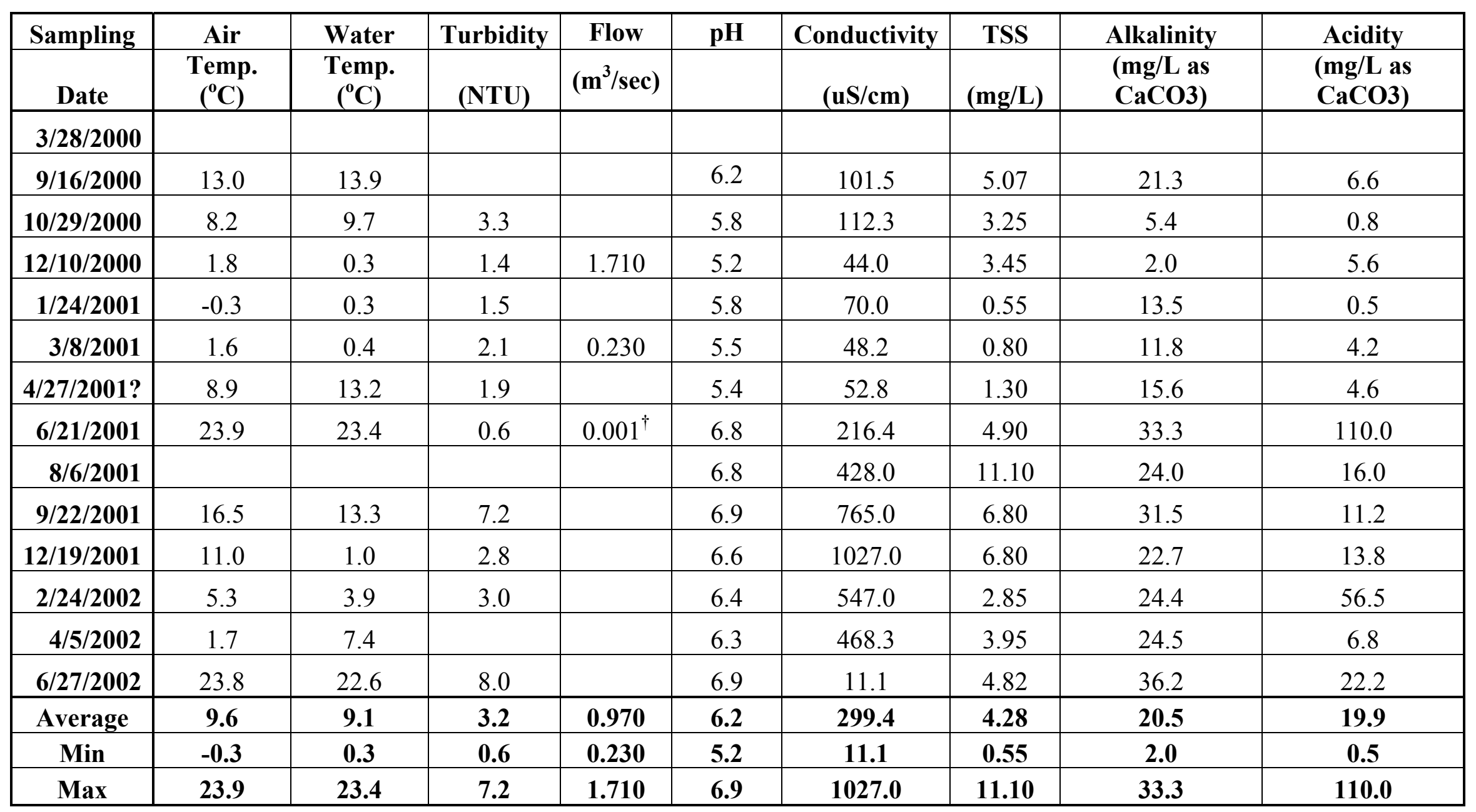

$\dagger$ Value Used for Below Detection Limit (BDL) is recorded as half of the Detection Limit Value

$\ddagger$ The Detection Limit Value for Chlorides before 5/10/2002 was equal to $1.00 \mathrm{mg} / \mathrm{L}$ for Mercuric Nitrate Buret Titration, Method 4500-CL- $-\mathrm{C}$ 
Table B-2b. Water Quality Grab Sample Data from BC-2.

\begin{tabular}{|c|c|c|c|c|c|c|c|c|c|c|c|}
\hline Sampling & Sulfate & Chloride & Iron & Calcium & Magnesium & Manganese & Aluminum & Nitrite & Nitrate & Ammonia & Phosphate \\
\hline Date & $(\mathrm{mg} / \mathrm{L})$ & $(\mathrm{mg} / \mathrm{L})$ & $(\mathrm{mg} / \mathrm{L})$ & $(\mathrm{mg} / \mathrm{L})$ & $(\mathrm{mg} / \mathrm{L})$ & $(\mathrm{mg} / \mathrm{L})$ & $(\mathrm{mg} / \mathrm{L})$ & $(\mathrm{mg} / \mathrm{L})$ & $(\mathrm{mg} / \mathrm{L})$ & $(\mathrm{mg} / \mathrm{L})$ & $(\mathrm{mg} / \mathrm{L})$ \\
\hline \multicolumn{12}{|l|}{$3 / 28 / 2000$} \\
\hline $9 / 16 / 2000$ & & 3.6 & 1.5 & 8.8 & 2.1 & 0.2 & 0.25 & $0.01^{\dagger}$ & 0.05 & 2.11 & $0.003^{\dagger}$ \\
\hline $10 / 29 / 2000$ & 54.3 & 2.2 & 0.8 & 12.7 & 3.4 & 0.5 & 0.23 & $0.01^{\dagger}$ & 0.12 & 2.92 & 0.016 \\
\hline $12 / 10 / 2000$ & 10.9 & & $0.05^{\dagger}$ & 3.1 & $0.05^{\dagger}$ & 0.8 & $0.05^{\dagger}$ & $0.01^{\dagger}$ & 0.12 & $0.005^{\dagger}$ & $0.003^{\dagger}$ \\
\hline $1 / 24 / 2001$ & 15.6 & 8.7 & 0.3 & 34.0 & 0.6 & 0.1 & 0.13 & $0.01^{\dagger}$ & 0.12 & $0.005^{\dagger}$ & $0.003^{\dagger}$ \\
\hline 3/8/2001 & 11.2 & 6.0 & 0.2 & 3.1 & 1.0 & & $0.05^{\dagger}$ & $0.01^{\dagger}$ & 0.12 & $0.005^{\dagger}$ & $0.003^{\dagger}$ \\
\hline 4/27/2001? & 285.0 & 3.0 & 0.2 & 2.0 & 0.9 & 0.1 & $0.05^{\dagger}$ & $0.01^{\dagger}$ & 0.07 & $0.005^{\dagger}$ & $0.003^{\dagger}$ \\
\hline $6 / 21 / 2001$ & 155.7 & $0.5^{\ddagger}$ & 0.6 & 21.3 & 12.0 & 1.5 & $0.05^{\dagger}$ & 0.02 & 0.50 & 0.369 & $0.003^{\dagger}$ \\
\hline $8 / 6 / 2001$ & 140.4 & 1.4 & 1.3 & 31.1 & 9.9 & 1.2 & 0.30 & $0.01^{\dagger}$ & 0.46 & 10.8 & 0.015 \\
\hline $9 / 22 / 2001$ & 282.2 & 2.6 & 1.0 & 65.9 & 15.4 & 1.2 & $0.05^{\dagger}$ & $0.01^{\dagger}$ & 0.34 & 26.3 & 0.010 \\
\hline $12 / 19 / 2001$ & 163.9 & 2.0 & 0.2 & 68.2 & 17.4 & 3.5 & 0.10 & 0.06 & 1.20 & 42.2 & 0.059 \\
\hline $2 / 24 / 2002$ & 132.6 & 2.8 & 0.3 & 4.3 & 14.6 & 4.1 & 0.20 & 0.03 & 0.55 & 18.8 & 0.055 \\
\hline 4/5/2002 & 125.6 & 1.3 & 0.4 & 31.9 & 11.7 & 2.6 & 0.10 & $0.01^{\dagger}$ & 0.68 & & 0.024 \\
\hline $6 / 27 / 2002$ & 198.0 & & 0.8 & 87.0 & 18.0 & 2.6 & 0.20 & $0.01^{\dagger}$ & 0.57 & 50.2 & 0.045 \\
\hline Average & 131.3 & 3.4 & 0.6 & 28.7 & 8.9 & 1.5 & 0.19 & 0.04 & 0.38 & 19.202 & 0.032 \\
\hline Min & 10.9 & 1.3 & 0.2 & 2.0 & 0.6 & 0.1 & 0.10 & 0.02 & 0.05 & 0.369 & 0.010 \\
\hline Max & 285.0 & 8.7 & 1.5 & 68.2 & 17.4 & 3.5 & 0.30 & 0.06 & 1.20 & 42.200 & 0.059 \\
\hline
\end{tabular}

$\dagger$ Value Used for Below Detection Limit (BDL) is recorded as half of the Detection Limit Value

* The Detection Limit Value for Chlorides before 5/10/2002 was equal to $1.00 \mathrm{mg} / \mathrm{L}$ for Mercuric Nitrate Buret Titration, Method 4500-CL ${ }^{-}$- C 
Table B-3a. Water Quality Grab Sample Data from BC-3.

\begin{tabular}{|c|c|c|c|c|c|c|c|c|c|}
\hline Sampling & Air & Water & Turbidity & Flow & pH & Conductivity & TSS & Alkalinity & Acidity \\
\hline Date & $\begin{array}{c}\text { Temp. } \\
\left({ }^{\circ} \mathrm{C}\right) \\
\end{array}$ & $\begin{array}{c}\text { Temp. } \\
\left({ }^{\circ} \mathrm{C}\right) \\
\end{array}$ & (NTU) & $\left(\mathrm{m}^{3} / \mathrm{sec}\right)$ & & $(\mathrm{uS} / \mathrm{cm})$ & $(\mathrm{mg} / \mathrm{L})$ & $\begin{array}{c}(\mathrm{mg} / \mathrm{L} \text { as } \\
\mathrm{CaCO3}) \\
\end{array}$ & $\begin{array}{c}(\mathrm{mg} / \mathrm{L} \text { as } \\
\mathrm{CaCO3}) \\
\end{array}$ \\
\hline $3 / 28 / 2000$ & 2.9 & 5.7 & 1.0 & 1.04 & 5.0 & 83.3 & 0.45 & 18.5 & 5.4 \\
\hline $9 / 16 / 2000$ & 6.8 & 10.2 & & & 6.0 & 236.0 & 3.15 & 32.3 & \\
\hline $10 / 29 / 2000$ & 4.1 & 9.1 & 2.2 & & 5.7 & 381.0 & 2.40 & 9.4 & $0.37^{\dagger}$ \\
\hline $12 / 10 / 2000$ & 1.8 & 0.4 & 2.4 & 3.97 & 5.9 & 91.0 & 1.50 & 6.6 & 0.6 \\
\hline $1 / 24 / 2001$ & -0.2 & 0.4 & 2.3 & & 6.8 & 166.1 & 0.80 & 21.7 & 5.8 \\
\hline $3 / 8 / 2001$ & 3.3 & 0.8 & 3.4 & 0.550 & 7.1 & 118.0 & 1.60 & 21.2 & 2.4 \\
\hline $4 / 27 / 2001$ & 17.2 & 12.0 & 2.2 & & 7.0 & 96.0 & 1.55 & 22.1 & $0.37^{\dagger}$ \\
\hline $6 / 21 / 2001$ & 23.0 & 17.6 & 4.1 & 0.180 & 7.3 & 128.6 & 4.65 & 30.8 & 158.0 \\
\hline $8 / 6 / 2001$ & 34.5 & 20.9 & 4.0 & 0.408 & 7.1 & 76.4 & 2.15 & 24.0 & 4.0 \\
\hline 9/22/2001 & & & 4.6 & 0.059 & 7.2 & 139.7 & 3.20 & 33.5 & 3.2 \\
\hline $12 / 19 / 2001$ & 12.1 & 4.0 & 4.0 & 0.616 & 6.6 & 154.7 & 3.20 & 18.4 & 4.8 \\
\hline $2 / 24 / 2002$ & 0.0 & 1.1 & 2.0 & 0.418 & 6.7 & 116.4 & 0.85 & 20.4 & 6.0 \\
\hline $4 / 5 / 2002$ & 4.4 & 5.2 & & 0.595 & 5.7 & 95.3 & 3.25 & 18.3 & 1.8 \\
\hline $6 / 27 / 2002$ & 24.1 & 21.3 & 5.0 & 0.058 & 7.0 & 143.5 & 7.40 & 34.1 & 3.4 \\
\hline Average & 10.3 & 8.4 & 3.1 & 0.790 & 6.5 & 144.7 & 2.58 & 22.2 & 3.7 \\
\hline Min & -0.2 & 0.4 & 1.0 & 0.058 & 5.0 & 76.4 & 0.45 & 6.6 & 0.6 \\
\hline Max & 34.5 & 21.3 & 5.0 & 3.970 & 7.3 & 381.0 & 7.40 & 34.1 & 6.0 \\
\hline
\end{tabular}

$\dagger$ Value Used for Below Detection Limit (BDL) is recorded as half of the Detection Limit Value

\pm The Detection Limit Value for Chlorides before 5/10/2002 was equal to $1.00 \mathrm{mg} / \mathrm{L}$ for Mercuric Nitrate Buret

Titration, Method 4500-CL- $-\mathrm{C}$ 
Table B-3b. Water Quality Grab Sample Data from BC-3.

\begin{tabular}{|c|c|c|c|c|c|c|c|c|c|c|c|}
\hline Sampling & Sulfate & Chloride & Iron & Calcium & Magnesium & Manganese & Aluminum & Nitrite & Nitrate & Ammonia & Phosphate \\
\hline Date & $(\mathrm{mg} / \mathrm{L})$ & $(\mathrm{mg} / \mathrm{L})$ & $(\mathrm{mg} / \mathrm{L})$ & $(\mathrm{mg} / \mathrm{L})$ & $(\mathrm{mg} / \mathrm{L})$ & $(\mathrm{mg} / \mathrm{L})$ & $(\mathrm{mg} / \mathrm{L})$ & $(\mathrm{mg} / \mathrm{L})$ & $(\mathrm{mg} / \mathrm{L})$ & $(\mathrm{mg} / \mathrm{L})$ & $(\mathrm{mg} / \mathrm{L})$ \\
\hline $3 / 28 / 2000$ & 28.3 & 2.9 & 0.2 & 16.6 & & & & $0.01^{\dagger}$ & $0.01^{\dagger}$ & 0.81 & 0.028 \\
\hline $9 / 16 / 2000$ & & & 1.7 & 25.0 & 9.6 & 1.4 & $0.05^{\dagger}$ & & & & \\
\hline $10 / 29 / 2000$ & 135.1 & $0.5^{\ddagger}$ & 16.6 & 36.4 & 16.8 & 2.9 & 0.2 & $0.01^{\dagger}$ & $0.01^{\dagger}$ & 0.10 & 0.024 \\
\hline $12 / 10 / 2000$ & 24.9 & & $0.05^{\dagger}$ & 8.3 & $0.05^{\dagger}$ & 1.7 & $0.05^{\dagger}$ & $0.01^{\dagger}$ & 0.23 & 1.02 & $0.003^{\dagger}$ \\
\hline $1 / 24 / 2001$ & 49.5 & 7.5 & 0.3 & 33.8 & 0.6 & 0.4 & 0.2 & $0.01^{\dagger}$ & 0.27 & 2.59 & $0.003^{\dagger}$ \\
\hline 3/8/2001 & 36.8 & 6.5 & 0.3 & 13.5 & 2.4 & $\mathrm{~B}$ & 0.1 & $0.01^{\dagger}$ & 0.29 & 1.09 & $0.003^{\dagger}$ \\
\hline 4/27/2001 & 29.7 & $0.5^{\ddagger}$ & 0.5 & 0.5 & 0.5 & 0.5 & 0.5 & 0.48 & 0.48 & 0.48 & 0.477 \\
\hline $6 / 21 / 2001$ & 20.2 & 1.5 & 2.0 & 9.4 & 1.6 & 0.1 & 0.2 & $0.01^{\dagger}$ & 0.57 & 12.50 & 0.048 \\
\hline $8 / 6 / 2001$ & 22.2 & 2.4 & 0.6 & 7.6 & 1.4 & 0.1 & 0.2 & 0.03 & 0.26 & 0.45 & 0.002 \\
\hline $9 / 22 / 2001$ & 33.6 & 2.6 & 1.3 & 15.7 & 2.5 & 0.1 & & $0.01^{\dagger}$ & 0.60 & 1.21 & 0.005 \\
\hline $12 / 19 / 2001$ & 83.3 & 2.0 & 0.8 & 15.0 & 4.2 & 0.7 & 0.3 & $0.01^{\dagger}$ & 0.45 & 4.50 & 0.011 \\
\hline $2 / 24 / 2002$ & 36.3 & 6.9 & 0.4 & 8.2 & 2.1 & 0.3 & 0.1 & $0.01^{\dagger}$ & 0.25 & 2.09 & 0.011 \\
\hline 4/5/2002 & 25.3 & 7.5 & 0.4 & 6.6 & 1.8 & 0.3 & 0.2 & $0.01^{\dagger}$ & 0.28 & 0.95 & 0.002 \\
\hline $6 / 27 / 2002$ & 37.0 & $0.5^{\ddagger}$ & 0.7 & 16.0 & 2.2 & 0.2 & 1.4 & 0.04 & 0.80 & 1.22 & 0.005 \\
\hline Average & 43.2 & 4.4 & 0.8 & 16.3 & 3.8 & 0.7 & 0.3 & 0.18 & 0.41 & 1.38 & 0.061 \\
\hline Min & 20.2 & 1.5 & 0.2 & 6.6 & 0.5 & 0.1 & 0.1 & $\mathbf{0 . 0 3}$ & 0.23 & 0.10 & 0.002 \\
\hline Max & 135.1 & 7.5 & 2.0 & 36.4 & 16.8 & 2.9 & 1.4 & 0.48 & 0.80 & 4.50 & 0.477 \\
\hline
\end{tabular}

$\dagger$ Value Used for Below Detection Limit (BDL) is recorded as half of the Detection Limit Value

* The Detection Limit Value for Chlorides before 5/10/2002 was equal to $1.00 \mathrm{mg} / \mathrm{L}$ for Mercuric Nitrate Buret Titration, Method 4500-CL ${ }^{-}$- C 
Table B-4a. Water Quality Grab Sample Data from BC-4.

\begin{tabular}{|c|c|c|c|c|c|c|c|c|c|}
\hline Sampling & Air & Water & Turbidity & Flow & pH & Conductivity & TSS & Alkalinity & Acidity \\
\hline Date & $\begin{array}{c}\text { Temp. } \\
\left({ }^{\circ} \mathrm{C}\right)\end{array}$ & $\begin{array}{c}\text { Temp. } \\
\left({ }^{\circ} \mathrm{C}\right) \\
\end{array}$ & (NTU) & $\left(\mathrm{m}^{3} / \mathrm{sec}\right)$ & & $(\mathrm{uS} / \mathrm{cm})$ & $(\mathrm{mg} / \mathrm{L})$ & $\begin{array}{c}(\mathrm{mg} / \mathrm{L} \text { as } \\
\mathrm{CaCO3}) \\
\end{array}$ & $\begin{array}{c}(\mathrm{mg} / \mathrm{L} \text { as } \\
\mathrm{CaCO3}) \\
\end{array}$ \\
\hline \multicolumn{10}{|l|}{$3 / 28 / 2000$} \\
\hline $9 / 16 / 2000$ & 7.8 & 11.2 & & & 4.5 & 226.0 & 4.87 & 15.9 & 21.3 \\
\hline $10 / 29 / 2000$ & 7.6 & 7.8 & 5.5 & & 4.1 & 300.0 & 3.15 & $0.37^{\dagger}$ & 21.5 \\
\hline $12 / 10 / 2000$ & 1.2 & -0.2 & 0.8 & & 4.3 & 374.0 & 4.75 & $0.37^{\dagger}$ & 33.4 \\
\hline $1 / 24 / 2001$ & 0.0 & 3.4 & 0.3 & & 3.7 & 456.0 & 0.20 & $0.37^{\dagger}$ & 81.4 \\
\hline $3 / 8 / 2001$ & 4.4 & 7.4 & 0.4 & & 6.2 & 110.0 & 2.25 & 15.3 & 6.1 \\
\hline $4 / 27 / 2001$ & 13.8 & 17.0 & 0.7 & & 3.6 & 429.0 & 1.60 & $0.37^{\dagger}$ & 58.8 \\
\hline $6 / 21 / 2001$ & 22.7 & 15.6 & 0.9 & & 4.6 & 102.8 & 7.35 & 14.9 & 4.0 \\
\hline $8 / 6 / 2001$ & 25.8 & 18.9 & 0.6 & & 3.2 & 384.5 & 3.00 & 20.0 & 6.0 \\
\hline $9 / 22 / 2001$ & 18.4 & 13.5 & 0.6 & & 4.4 & 200.0 & 2.80 & 10.4 & 38.4 \\
\hline $12 / 19 / 2001$ & 3.6 & 5.9 & 4.3 & & 4.7 & 218.0 & 2.80 & 16.7 & 30.8 \\
\hline $2 / 24 / 2002$ & 9.1 & 3.9 & 1.0 & & 4.6 & 223.0 & 2.65 & 15.5 & 35.4 \\
\hline $4 / 5 / 2002$ & 3.7 & 6.5 & & & 2.8 & 430.7 & 0.70 & & 54.0 \\
\hline $6 / 27 / 2002$ & 21.7 & 18.7 & 5.0 & & 4.4 & 271.5 & 2.50 & & 44.0 \\
\hline Average & 10.8 & 10.0 & 1.8 & 0.0 & 4.2 & 286.6 & 3.0 & 15.5 & 33.5 \\
\hline Min & 0.0 & -0.2 & 0.3 & 0.0 & 2.8 & 102.8 & 0.2 & 10.4 & 4.0 \\
\hline Max & 25.8 & 18.9 & 5.5 & 0.0 & 6.2 & 456.0 & 7.4 & 20.0 & 81.4 \\
\hline
\end{tabular}

$\dagger$ Value Used for Below Detection Limit (BDL) is recorded as half of the Detection Limit Value

+ The Detection Limit Value for Chlorides before 5/10/2002 was equal to $1.00 \mathrm{mg} / \mathrm{L}$ for Mercuric Nitrate Buret Titration, Method 4500-CL- $-\mathrm{C}$ 
Table B-4b. Water Quality Grab Sample Data from BC-4.

\begin{tabular}{|c|c|c|c|c|c|c|c|c|c|c|c|}
\hline Sampling & Sulfate & Chloride & Iron & Calcium & Magnesium & Manganese & Aluminum & Nitrite & Nitrate & Ammonia & Phosphate \\
\hline Date & $(\mathrm{mg} / \mathrm{L})$ & $(\mathrm{mg} / \mathrm{L})$ & $(\mathrm{mg} / \mathrm{L})$ & $(\mathrm{mg} / \mathrm{L})$ & $(\mathrm{mg} / \mathrm{L})$ & $(\mathrm{mg} / \mathrm{L})$ & $(\mathrm{mg} / \mathrm{L})$ & $(\mathrm{mg} / \mathrm{L})$ & $(\mathrm{mg} / \mathrm{L})$ & $(\mathrm{mg} / \mathrm{L})$ & $(\mathrm{mg} / \mathrm{L})$ \\
\hline \multicolumn{12}{|l|}{$3 / 28 / 2000$} \\
\hline $9 / 16 / 2000$ & & & 2.0 & 27.4 & 10.0 & 2.4 & 1.6 & & & & \\
\hline $10 / 29 / 2000$ & 136.9 & 1.2 & 1.9 & 27.0 & 9.7 & 2.1 & 1.2 & $0.01^{\dagger}$ & $0.01^{\dagger}$ & 0.02 & $0.003^{\dagger}$ \\
\hline $12 / 10 / 2000$ & 172.6 & & 7.4 & 38.2 & 1.9 & 13.0 & 1.1 & $0.01^{\dagger}$ & 0.02 & 0.02 & 0.039 \\
\hline $1 / 24 / 2001$ & 188.0 & $0.5^{*}$ & 2.4 & 64.2 & 1.0 & 2.3 & 5.1 & $0.01^{\dagger}$ & $0.01^{\dagger}$ & $0.005^{\dagger}$ & $0.003^{\dagger}$ \\
\hline $3 / 8 / 2001$ & 125.0 & 4.0 & 1.4 & 13.7 & 12.1 & & 2.7 & $0.01^{\dagger}$ & $0.01^{\dagger}$ & $0.005^{\dagger}$ & $0.003^{\dagger}$ \\
\hline $4 / 27 / 2001$ & 138.0 & 6.5 & 2.2 & 11.2 & 13.4 & 2.4 & 3.0 & $0.01^{\dagger}$ & $0.01^{\dagger}$ & 0.02 & $0.003^{\dagger}$ \\
\hline $6 / 21 / 2001$ & 40.5 & 2.0 & 3.7 & 17.4 & 6.9 & 1.7 & 0.6 & $0.01^{\dagger}$ & $0.01^{\dagger}$ & $0.005^{\dagger}$ & $0.003^{\dagger}$ \\
\hline $8 / 6 / 2001$ & 100.8 & $0.5^{\ddagger}$ & 3.2 & 11.8 & 10.9 & 2.1 & 2.6 & $0.01^{\dagger}$ & $0.01^{\dagger}$ & $0.005^{\dagger}$ & 0.005 \\
\hline $9 / 22 / 2001$ & 81.8 & $0.5^{*}$ & 1.5 & 15.9 & 5.0 & 1.0 & 0.5 & $0.01^{\dagger}$ & $0.01^{\dagger}$ & 0.03 & $0.003^{\dagger}$ \\
\hline $12 / 19 / 2001$ & 109.3 & $0.5^{\ddagger}$ & 4.0 & 19.3 & 9.0 & 2.3 & 0.8 & $0.01^{\dagger}$ & 0.02 & 0.05 & 0.027 \\
\hline $2 / 24 / 2002$ & 102.9 & 3.8 & 3.7 & 20.2 & 10.8 & 2.3 & 3.4 & $0.01^{\dagger}$ & $0.01^{\dagger}$ & $0.005^{\dagger}$ & 0.044 \\
\hline 4/5/2002 & 115.6 & $0.5^{*}$ & 0.7 & 16.3 & 11.5 & 2.3 & 4.0 & $0.01^{\dagger}$ & $0.01^{\dagger}$ & 0.02 & 0.030 \\
\hline $6 / 27 / 2002$ & 132.6 & & 2.7 & 21.5 & 8.4 & 2.0 & 8.4 & $0.01^{\dagger}$ & 0.03 & 0.04 & 0.021 \\
\hline Average & 120.3 & 3.5 & 2.8 & 20.0 & 8.5 & 2.1 & 2.7 & 0.01 & 0.02 & $\mathbf{0 . 0 3}$ & 0.028 \\
\hline Min & 40.5 & 1.2 & 0.7 & 11.2 & 1.0 & 1.0 & 0.5 & 0.01 & 0.02 & 0.02 & 0.005 \\
\hline Max & 188.0 & 6.5 & 7.4 & 38.2 & 13.4 & 2.4 & 8.4 & 0.01 & $\mathbf{0 . 0 3}$ & 0.05 & 0.044 \\
\hline
\end{tabular}

$\dagger$ Value Used for Below Detection Limit (BDL) is recorded as half of the Detection Limit Value

\$ The Detection Limit Value for Chlorides before 5/10/2002 was equal to $1.00 \mathrm{mg} / \mathrm{L}$ for Mercuric Nitrate Buret Titration, Method 4500-CL- - C 
Table B-5a. Water Quality Grab Sample Data from BC-5.

\begin{tabular}{|c|c|c|c|c|c|c|c|c|c|}
\hline Sampling & Air & Water & Turbidity & Flow & pH & Conductivity & TSS & Alkalinity & Acidity \\
\hline Date & $\begin{array}{c}\text { Temp. } \\
\left({ }^{\circ} \mathrm{C}\right) \\
\end{array}$ & $\begin{array}{c}\text { Temp. } \\
\left({ }^{\circ} \mathrm{C}\right)\end{array}$ & (NTU) & $\left(\mathrm{m}^{3} / \mathrm{sec}\right)$ & & $(\mathrm{uS} / \mathrm{cm})$ & $(\mathrm{mg} / \mathrm{L})$ & $\begin{array}{c}(\mathrm{mg} / \mathrm{L} \text { as } \\
\mathrm{CaCO3}) \\
\end{array}$ & $\begin{array}{c}(\mathrm{mg} / \mathrm{L} \text { as } \\
\mathrm{CaCO3}) \\
\end{array}$ \\
\hline \multicolumn{10}{|l|}{$3 / 28 / 2000$} \\
\hline $9 / 16 / 2000$ & 9.5 & 10.5 & & & 3.1 & 907.0 & 2.12 & $0.37^{\dagger}$ & 146.5 \\
\hline $10 / 29 / 2000$ & 7.7 & 4.0 & 0.3 & & 3.0 & 846.7 & 0.54 & $0.37^{\dagger}$ & 155.6 \\
\hline \multicolumn{10}{|l|}{$12 / 10 / 2000$} \\
\hline $1 / 24 / 2001$ & 0.6 & 0.3 & 1.1 & $0.001^{\dagger}$ & 3.3 & 129.0 & 0.25 & $0.37^{\dagger}$ & 129.3 \\
\hline $3 / 8 / 2001$ & 1.9 & 0.3 & 6.5 & & 3.2 & 480.0 & 6.02 & $0.37^{\dagger}$ & 139.5 \\
\hline $4 / 27 / 2001$ & 14.7 & 13.8 & 0.6 & & 3.0 & 943.0 & 0.55 & $0.37^{\dagger}$ & 94.5 \\
\hline $6 / 21 / 2001$ & 25.0 & 26.8 & 1.0 & $0.001^{\dagger}$ & 3.0 & 142.8 & 8.60 & $0.37^{\dagger}$ & 18.0 \\
\hline $8 / 6 / 2001$ & 26.9 & 25.6 & 0.2 & 0.007 & 2.5 & 859.0 & 1.10 & $0.37^{\dagger}$ & 130.0 \\
\hline $9 / 22 / 2001$ & 18.3 & 15.0 & 0.6 & $0.001^{\dagger}$ & 3.0 & 958.0 & 0.45 & $0.37^{\dagger}$ & 153.6 \\
\hline $12 / 19 / 2001$ & 4.6 & 3.1 & 0.4 & $0.001^{\dagger}$ & 3.2 & 619.0 & 0.45 & & 98.4 \\
\hline $2 / 24 / 2002$ & 8.5 & 1.9 & 10.0 & 0.013 & 3.1 & 753.0 & 1.80 & & 164.6 \\
\hline $4 / 5 / 2002$ & 3.6 & 5.0 & & 0.002 & 2.1 & 911.0 & 1.95 & & 148.2 \\
\hline $6 / 27 / 2002$ & 21.0 & 21.4 & 1.0 & $0.001^{\dagger}$ & 2.8 & 1107.0 & 0.70 & & 171.6 \\
\hline Average & 11.9 & 10.6 & 2.2 & 0.007 & 2.9 & 721.3 & 2.04 & 0.37 & 139.2 \\
\hline Min & 0.6 & 0.3 & 0.2 & 0.002 & 2.1 & 129.0 & 0.25 & 0.37 & 94.5 \\
\hline Max & 26.9 & 26.8 & 10.0 & 0.013 & 3.3 & 1107.0 & 8.60 & $\mathbf{0 . 3 7}$ & 171.6 \\
\hline
\end{tabular}

$\dagger$ Value Used for Below Detection Limit (BDL) is recorded as half of the Detection Limit Value

\pm The Detection Limit Value for Chlorides before 5/10/2002 was equal to $1.00 \mathrm{mg} / \mathrm{L}$ for Mercuric Nitrate Buret Titration, Method 4500-CL- $-\mathrm{C}$ 
Table B-5b. Water Quality Grab Sample Data from BC-5.

\begin{tabular}{|c|c|c|c|c|c|c|c|c|c|c|c|}
\hline Sampling & Sulfate & Chloride & Iron & Calcium & Magnesium & Manganese & Aluminum & Nitrite & Nitrate & Ammonia & Phosphate \\
\hline Date & $(\mathrm{mg} / \mathrm{L})$ & $(\mathrm{mg} / \mathrm{L})$ & $(\mathrm{mg} / \mathrm{L})$ & $(\mathrm{mg} / \mathrm{L})$ & $(\mathrm{mg} / \mathrm{L})$ & $(\mathrm{mg} / \mathrm{L})$ & $(\mathrm{mg} / \mathrm{L})$ & $(\mathrm{mg} / \mathrm{L})$ & $(\mathrm{mg} / \mathrm{L})$ & $(\mathrm{mg} / \mathrm{L})$ & $(\mathrm{mg} / \mathrm{L})$ \\
\hline \multicolumn{12}{|l|}{$3 / 28 / 2000$} \\
\hline $9 / 16 / 2000$ & & & 13.6 & 23.3 & 23.7 & 6.8 & 7.9 & & & & \\
\hline $10 / 29 / 2000$ & 251.1 & $0.5^{\ddagger}$ & 13.0 & 25.1 & 26.4 & 7.0 & 9.3 & $0.01^{\dagger}$ & 0.18 & 0.10 & 0.048 \\
\hline $12 / 10 / 2000$ & 185.2 & 1.2 & 11.3 & & & & & & $0.01^{\dagger}$ & $0.005^{\dagger}$ & 0.005 \\
\hline $1 / 24 / 2001$ & 274.0 & 5.5 & 11.0 & 49.4 & 0.6 & 5.7 & 7.8 & $0.01^{\dagger}$ & $0.01^{\dagger}$ & 0.12 & 0.003 \\
\hline 3/8/2001 & 290.0 & 11.0 & 10.1 & 10.4 & 23.3 & & 6.7 & $0.01^{\dagger}$ & 0.04 & 0.14 & 0.003 \\
\hline 4/27/2001 & 356.0 & $0.5^{\ddagger}$ & 16.3 & 9.2 & 31.7 & 8.1 & 6.5 & $0.01^{\dagger}$ & 0.02 & 0.18 & 0.003 \\
\hline $6 / 21 / 2001$ & 61.2 & $0.5^{\ddagger}$ & 4.4 & 11.6 & 14.6 & 4.2 & 3.4 & $0.01^{\dagger}$ & 0.08 & 0.08 & 0.003 \\
\hline $8 / 6 / 2001$ & 195.3 & $0.5^{*}$ & 3.7 & 6.9 & 13.3 & 4.7 & 4.1 & $0.01^{\dagger}$ & 0.07 & 0.10 & 0.006 \\
\hline $9 / 22 / 2001$ & 238.2 & $0.5^{\ddagger}$ & 4.3 & 14.0 & 24.9 & 6.3 & 7.6 & $0.01^{\dagger}$ & 0.08 & 0.04 & 0.003 \\
\hline $12 / 19 / 2001$ & 138.9 & $0.5^{\ddagger}$ & 4.4 & 9.0 & 13.9 & 3.9 & 5.8 & $0.01^{\dagger}$ & $0.01^{\dagger}$ & 0.03 & 0.078 \\
\hline $2 / 24 / 2002$ & 138.7 & 1.1 & 7.9 & 12.9 & 19.3 & 5.9 & 7.2 & $0.01^{\dagger}$ & $0.01^{\dagger}$ & 0.16 & 0.096 \\
\hline 4/5/2002 & 171.6 & 1.5 & 9.2 & 13.2 & 19.5 & 5.6 & 7.9 & $0.01^{\dagger}$ & $0.01^{\dagger}$ & 0.16 & 0.102 \\
\hline $6 / 27 / 2002$ & 184.3 & & 5.9 & 13.9 & 20.0 & 5.9 & 8.3 & $0.01^{\dagger}$ & 0.09 & 0.05 & 0.107 \\
\hline Average & 220.3 & 4.1 & 8.9 & 16.6 & 21.0 & 5.8 & 6.9 & 0.01 & 0.08 & 0.11 & 0.038 \\
\hline Min & 138.7 & 1.1 & 3.7 & 6.9 & 13.3 & 3.9 & 3.4 & 0.01 & 0.02 & $\mathbf{0 . 0 3}$ & 0.003 \\
\hline Max & 356.0 & 11.0 & 16.3 & 49.4 & 31.7 & 8.1 & 9.3 & 0.01 & 0.18 & 0.18 & 0.107 \\
\hline
\end{tabular}

$\dagger$ Value Used for Below Detection Limit (BDL) is recorded as half of the Detection Limit Value

* The Detection Limit Value for Chlorides before 5/10/2002 was equal to $1.00 \mathrm{mg} / \mathrm{L}$ for Mercuric Nitrate Buret Titration, Method 4500-CL ${ }^{-}$- C 
Table B-6a. Water Quality Grab Sample Data from BC-6.

\begin{tabular}{|c|c|c|c|c|c|c|c|c|c|}
\hline Sampling & Air & Water & Turbidity & Flow & pH & Conductivity & TSS & Alkalinity & Acidity \\
\hline Date & $\begin{array}{c}\text { Temp. } \\
\left({ }^{\circ} \mathrm{C}\right)\end{array}$ & $\begin{array}{c}\text { Temp. } \\
\left({ }^{\circ} \mathrm{C}\right) \\
\end{array}$ & (NTU) & $\left(\mathrm{m}^{3} / \mathrm{sec}\right)$ & & $(\mathrm{uS} / \mathrm{cm})$ & $(\mathrm{mg} / \mathrm{L})$ & $\begin{array}{c}\mathrm{mg} / \mathrm{L} \text { as } \\
\mathrm{CaCO3}) \\
\end{array}$ & $\begin{array}{c}(\mathrm{mg} / \mathrm{L} \text { as } \\
\mathrm{CaCO3})\end{array}$ \\
\hline $3 / 28 / 2000$ & 2.0 & 5.2 & 2.5 & 1.511 & 4.9 & 120.1 & 2.85 & 18.2 & 8.4 \\
\hline $9 / 16 / 2000$ & 9.7 & 13.0 & & & 6.5 & 143.0 & 6.73 & 24.1 & 4.4 \\
\hline $10 / 29 / 2000$ & 9.4 & 7.5 & 3.2 & 1.164 & 6.3 & 141.5 & 5.33 & 3.7 & 3.2 \\
\hline $12 / 10 / 2000$ & 1.6 & 0.3 & 4.6 & 7.810 & 7.8 & 123.0 & 5.91 & 5.6 & 3.6 \\
\hline $1 / 24 / 2001$ & -0.3 & 0.3 & 4.2 & & 6.3 & 191.7 & 4.85 & 19.5 & 8.1 \\
\hline $3 / 8 / 2001$ & 1.8 & 1.2 & 7.5 & & 6.2 & 147.0 & 9.60 & 16.0 & 4.7 \\
\hline $4 / 27 / 2001$ & 16.2 & 14.1 & & & 6.3 & 150.2 & 6.05 & 18.8 & 8.0 \\
\hline $6 / 21 / 2001$ & 25.3 & 25.0 & 3.6 & 0.330 & 6.1 & 135.6 & 5.60 & 17.5 & 30.0 \\
\hline $8 / 6 / 2001$ & \multicolumn{9}{|c|}{ Monitoring Discontinued for this site } \\
\hline Average & 8.2 & 8.3 & 4.2 & 2.704 & 6.3 & 144.0 & 5.86 & 15.4 & 5.8 \\
\hline Min & -0.3 & 0.3 & 2.5 & 0.330 & 4.9 & 120.1 & 2.85 & 3.7 & 3.2 \\
\hline $\operatorname{Max}$ & 25.3 & 25.0 & 7.5 & 7.810 & 7.8 & 191.7 & 9.60 & 24.1 & 8.4 \\
\hline
\end{tabular}

$\dagger$ Value Used for Below Detection Limit (BDL) is recorded as half of the Detection Limit Value

\$ The Detection Limit Value for Chlorides before 5/10/2002 was equal to $1.00 \mathrm{mg} / \mathrm{L}$ for Mercuric Nitrate Buret

Titration, Method 4500-CL'- C 
Table B-6b. Water Quality Grab Sample Data from BC-6.

\begin{tabular}{|c|c|c|c|c|c|c|c|c|c|c|c|}
\hline Sampling & Sulfate & Chloride & Iron & Calcium & Magnesium & Manganese & Aluminum & Nitrite & Nitrate & Ammonia & Phosphate \\
\hline Date & $(\mathrm{mg} / \mathrm{L})$ & $(\mathrm{mg} / \mathrm{L})$ & $(\mathrm{mg} / \mathrm{L})$ & $(\mathrm{mg} / \mathrm{L})$ & $(\mathrm{mg} / \mathrm{L})$ & $(\mathrm{mg} / \mathrm{L})$ & $(\mathrm{mg} / \mathrm{L})$ & $(\mathrm{mg} / \mathrm{L})$ & $(\mathrm{mg} / \mathrm{L})$ & $(\mathrm{mg} / \mathrm{L})$ & $(\mathrm{mg} / \mathrm{L})$ \\
\hline $3 / 28 / 2000$ & 43.3 & 3.3 & 0.3 & 25.0 & & & & $0.01^{\dagger}$ & 0.01 & 0.48 & 0.016 \\
\hline $9 / 16 / 2000$ & & & 1.2 & 12.6 & 3.2 & 0.4 & 0.5 & & & & \\
\hline $10 / 29 / 2000$ & 49.1 & 2.2 & 0.6 & 15.3 & 4.2 & 0.4 & 0.4 & $0.01^{\dagger}$ & 0.15 & 0.30 & $0.003^{\dagger}$ \\
\hline $12 / 10 / 2000$ & 36.1 & & 0.7 & 11.8 & 0.4 & 3.2 & 0.7 & $0.01^{\dagger}$ & 0.23 & 0.54 & 0.036 \\
\hline $1 / 24 / 2001$ & 59.0 & 9.7 & 0.4 & 41.2 & 3.9 & 0.5 & 0.7 & $0.01^{\dagger}$ & 0.26 & 2.08 & $0.003^{\dagger}$ \\
\hline $3 / 8 / 2001$ & 46.6 & 7.5 & 0.3 & 15.7 & 4.4 & & 0.1 & $0.01^{\dagger}$ & 0.27 & 0.54 & $0.003^{\dagger}$ \\
\hline $4 / 27 / 2001$ & 51.4 & 3.5 & 0.7 & 13.0 & 5.1 & 0.7 & 0.9 & $0.01^{\dagger}$ & 0.34 & 0.62 & $0.003^{\dagger}$ \\
\hline $6 / 21 / 2001$ & 39.6 & 2.0 & 1.0 & 13.8 & 5.2 & 0.7 & 0.3 & $0.01^{\dagger}$ & 0.31 & 0.10 & $0.003^{\dagger}$ \\
\hline $8 / 6 / 2001$ & & & & Monitor & ng Discontinu & ed for this site & & & & & \\
\hline Average & 46.4 & 4.7 & 0.6 & 18.6 & 3.8 & 1.0 & 0.5 & 0.01 & 0.2 & 0.7 & 0.026 \\
\hline Min & 36.1 & 2.0 & 0.3 & 11.8 & 0.4 & 0.4 & 0.1 & 0.01 & $\mathbf{0 . 0}$ & 0.1 & 0.016 \\
\hline $\operatorname{Max}$ & 59.0 & 9.7 & 1.2 & 41.2 & 5.2 & 3.2 & 0.9 & 0.01 & 0.3 & 2.1 & 0.036 \\
\hline
\end{tabular}

$\dagger$ Value Used for Below Detection Limit (BDL) is recorded as half of the Detection Limit Value

\$ The Detection Limit Value for Chlorides before 5/10/2002 was equal to $1.00 \mathrm{mg} / \mathrm{L}$ for Mercuric

Nitrate Buret Titration, Method 4500-CL - C 
Table B-7a. Water Quality Grab Sample Data from BC-7.

\begin{tabular}{|c|c|c|c|c|c|c|c|c|c|}
\hline Sampling & Air & Water & Turbidity & Flow & pH & Conductivity & TSS & Alkalinity & Acidity \\
\hline Date & $\begin{array}{c}\text { Temp. } \\
\left({ }^{\circ} \mathrm{C}\right) \\
\end{array}$ & $\begin{array}{c}\text { Temp. } \\
\left({ }^{\circ} \mathrm{C}\right)\end{array}$ & $(\mathbf{N T U})$ & $\left(\mathrm{m}^{3} / \mathrm{sec}\right)$ & & (uS/cm) & $(\mathrm{mg} / \mathrm{L})$ & $\begin{array}{c}\mathrm{mg} / \mathrm{L} \text { as } \\
\mathrm{CaCO3}) \\
\end{array}$ & $\begin{array}{c}(\mathrm{mg} / \mathrm{L} \text { as } \\
\mathrm{CaCO3})\end{array}$ \\
\hline $9 / 16 / 2000$ & 9.7 & 14.1 & & & 3.7 & 439.0 & 3.50 & $0.37^{\dagger}$ & 86.4 \\
\hline $3 / 8 / 2001$ & 3.3 & 2.2 & 2.2 & 0.040 & 4.4 & 260.0 & 6.60 & 9.6 & 36.5 \\
\hline $4 / 27 / 2001$ & 17.3 & 15.2 & 0.5 & & 3.8 & 370.0 & 0.70 & 0.4 & 86.7 \\
\hline $6 / 21 / 2001$ & 28.2 & 25.0 & 4.4 & 0.001 & 3.9 & 148.9 & 8.89 & 0.4 & 16.0 \\
\hline $8 / 6 / 2001$ & 29.8 & 24.4 & 0.4 & 0.254 & 3.8 & 238.0 & 0.80 & 15.0 & 30.0 \\
\hline $9 / 22 / 2001$ & 18.7 & 18.7 & 2.2 & & 3.8 & 369.0 & 3.05 & $0.37^{\dagger}$ & 62.4 \\
\hline $12 / 19 / 2001$ & 11.3 & 4.9 & 4.1 & & 4.0 & 187.1 & 3.05 & & 30.2 \\
\hline $2 / 24 / 2002$ & 8.0 & 5.1 & 1.0 & & 4.2 & 234.0 & 1.20 & 10.1 & 65.0 \\
\hline 4/5/2002 & 3.1 & 5.9 & & & 3.5 & 342.5 & 1.22 & & 78.0 \\
\hline $6 / 27 / 2002$ & 20.5 & 23.5 & 7.0 & $0.001^{\dagger}$ & 3.4 & 458.2 & 2.05 & & 74.6 \\
\hline Average & 15.0 & 13.9 & 2.7 & 0.098 & 3.9 & 304.7 & 3.11 & 7.1 & 56.6 \\
\hline Min & 3.1 & 2.2 & 0.4 & 0.001 & 3.4 & 148.9 & 0.70 & 0.4 & 16.0 \\
\hline Max & 29.8 & 25.0 & 7.0 & 0.254 & 4.4 & 458.2 & 8.89 & 15.0 & 86.7 \\
\hline
\end{tabular}

$\dagger$ Value Used for Below Detection Limit (BDL) is recorded as half of the Detection Limit Value

\$ The Detection Limit Value for Chlorides before 5/10/2002 was equal to $1.00 \mathrm{mg} / \mathrm{L}$ for Mercuric Nitrate Buret Titration, Method 4500-CL ${ }^{-}-\mathrm{C}$ 
Table B-7b. Water Quality Grab Sample Data from BC-7.

\begin{tabular}{|c|c|c|c|c|c|c|c|c|c|c|c|}
\hline Sampling & Sulfate & Chloride & Iron & Calcium & Magnesium & Manganese & Aluminum & Nitrite & Nitrate & Ammonia & Phosphate \\
\hline Date & $(\mathrm{mg} / \mathrm{L})$ & $(\mathrm{mg} / \mathrm{L})$ & $(\mathrm{mg} / \mathrm{L})$ & $(\mathrm{mg} / \mathrm{L})$ & $(\mathrm{mg} / \mathrm{L})$ & $(\mathrm{mg} / \mathrm{L})$ & $(\mathrm{mg} / \mathrm{L})$ & $(\mathrm{mg} / \mathrm{L})$ & $(\mathrm{mg} / \mathrm{L})$ & $(\mathrm{mg} / \mathrm{L})$ & $(\mathrm{mg} / \mathrm{L})$ \\
\hline $9 / 16 / 2000$ & & & 3.1 & 19.1 & 13.4 & 5.7 & & & & & \\
\hline $3 / 8 / 2001$ & 43.0 & $0.5^{*}$ & 0.5 & 13.5 & 12.0 & & 4.0 & $0.01^{\dagger}$ & 0.19 & 0.01 & $0.003^{\dagger}$ \\
\hline $4 / 27 / 2001$ & 161.0 & 1.0 & 1.7 & 3.8 & 12.0 & 0.7 & 8.2 & $0.01^{\dagger}$ & 0.04 & 0.05 & $0.003^{\dagger}$ \\
\hline $6 / 21 / 2001$ & 83.7 & $0.5^{\ddagger}$ & 4.8 & 9.1 & 9.9 & 2.9 & 3.9 & $0.01^{\dagger}$ & $0.01^{\dagger}$ & 0.19 & $0.003^{\dagger}$ \\
\hline $8 / 6 / 2001$ & 85.5 & $0.5^{\dagger}$ & 0.5 & 10.0 & 7.5 & 1.3 & 2.3 & $0.01^{\dagger}$ & 0.04 & 0.02 & $0.003^{\dagger}$ \\
\hline $9 / 22 / 2001$ & 121.4 & & 3.1 & 12.6 & 12.1 & 4.0 & 5.6 & $0.01^{\dagger}$ & $0.01^{\dagger}$ & 1.08 & $0.003^{\dagger}$ \\
\hline $12 / 19 / 2001$ & 75.4 & & 1.4 & 5.5 & 5.0 & 2.2 & 3.0 & $0.01^{\dagger}$ & 0.05 & 0.03 & 0.035 \\
\hline $2 / 24 / 2002$ & 86.6 & 1.9 & 1.2 & 7.3 & 6.7 & 2.6 & 4.8 & $0.01^{\dagger}$ & 0.02 & 0.05 & 0.047 \\
\hline 4/5/2002 & 108.7 & $0.5^{\dagger}$ & 1.4 & 7.0 & 9.1 & 3.3 & 9.6 & $0.01^{\dagger}$ & 0.07 & 0.05 & 0.039 \\
\hline $6 / 27 / 2002$ & 143.7 & & 5.8 & 12.5 & 10.7 & 5.8 & 4.9 & $0.01^{\dagger}$ & 0.05 & 0.57 & 0.051 \\
\hline Average & 101.0 & 1.5 & 2.4 & 10.0 & 9.8 & 3.2 & 5.1 & 0.01 & $\mathbf{0 . 0 7}$ & 0.23 & 0.043 \\
\hline Min & 43.0 & 1.0 & 0.5 & 3.8 & $\mathbf{5 . 0}$ & 0.7 & 2.3 & 0.01 & 0.02 & 0.01 & $\mathbf{0 . 0 3 5}$ \\
\hline Max & 161.0 & 1.9 & 5.8 & 19.1 & 13.4 & 5.8 & 9.6 & 0.01 & 0.19 & 1.08 & 0.051 \\
\hline
\end{tabular}

$\dagger$ Value Used for Below Detection Limit (BDL) is recorded as half of the Detection Limit Value

\$ The Detection Limit Value for Chlorides before 5/10/2002 was equal to $1.00 \mathrm{mg} / \mathrm{L}$ for Mercuric Nitrate Buret Titration, Method 4500-CL - C 
Table B-8a. Water Quality Grab Sample Data from BC-8.

\begin{tabular}{|c|c|c|c|c|c|c|c|c|c|}
\hline Sampling & Air & Water & Turbidity & Flow & pH & Conductivity & TSS & Alkalinity & Acidity \\
\hline Date & $\begin{array}{c}\text { Temp. } \\
\left({ }^{\circ} \mathrm{C}\right)\end{array}$ & $\begin{array}{l}\text { Temp. } \\
\left({ }^{\circ} \mathrm{C}\right)\end{array}$ & (NTU) & $\left(\mathrm{m}^{3} / \mathrm{sec}\right)$ & & (uS/cm) & $(\mathrm{mg} / \mathrm{L})$ & $\begin{array}{c}(\mathrm{mg} / \mathrm{L} \text { as } \\
\mathrm{CaCO3})\end{array}$ & $\begin{array}{l}\text { (mg/L as } \\
\mathrm{CaCO3})\end{array}$ \\
\hline $4 / 27 / 2001$ & 15.0 & 13.8 & 1.6 & & 4.3 & 287.0 & 2.60 & 0.4 & 42.3 \\
\hline $6 / 21 / 2001$ & 23.9 & 23.4 & 0.6 & 0.080 & 4.1 & 159.8 & 5.85 & 0.4 & 46.0 \\
\hline $8 / 6 / 2001$ & 27.3 & 27.8 & 5.1 & & 3.4 & 321.0 & 13.00 & $0.37^{\dagger}$ & 72.0 \\
\hline $9 / 22 / 2001$ & 22.6 & 18.1 & 0.7 & 0.044 & 4.2 & 415.0 & 0.60 & $0.37^{\dagger}$ & 53.6 \\
\hline $12 / 19 / 2001$ & 8.0 & 4.6 & 1.4 & 0.141 & 4.7 & 122.6 & 0.60 & 13.7 & 16.6 \\
\hline $2 / 24 / 2002$ & 5.8 & 3.6 & 1.0 & 0.045 & 4.5 & 210.0 & 1.15 & 14.9 & 36.0 \\
\hline 4/5/2002 & 6.1 & 5.3 & & 0.082 & 3.8 & 247.4 & 0.90 & 16.4 & 31.8 \\
\hline $6 / 27 / 2002$ & 20.5 & 24.1 & 1.0 & 0.028 & 3.9 & 415.0 & 1.00 & & 49.6 \\
\hline Average & 16.2 & 15.1 & 1.6 & 0.070 & 4.1 & 272.2 & 3.21 & 9.2 & 43.5 \\
\hline Min & 5.8 & 3.6 & 0.6 & 0.028 & 3.4 & 122.6 & 0.60 & 0.4 & 16.6 \\
\hline Max & 27.3 & 27.8 & 5.1 & 0.141 & 4.7 & 415.0 & 13.00 & 16.4 & 72.0 \\
\hline
\end{tabular}

$\dagger$ Value Used for Below Detection Limit (BDL) is recorded as half of the Detection Limit Value

† The Detection Limit Value for Chlorides before 5/10/2002 was equal to $1.00 \mathrm{mg} / \mathrm{L}$ for Mercuric Nitrate Buret

Titration, Method 4500-CL- - C 
Table B-8b. Water Quality Grab Sample Data from BC-8.

\begin{tabular}{|c|c|c|c|c|c|c|c|c|c|c|c|}
\hline Sampling & Sulfate & Chloride & Iron & Calcium & Magnesium & Manganese & Aluminum & Nitrite & Nitrate & Ammonia & Phosphate \\
\hline Date & $(\mathrm{mg} / \mathrm{L})$ & $(\mathrm{mg} / \mathrm{L})$ & $(\mathrm{mg} / \mathrm{L})$ & $(\mathrm{mg} / \mathrm{L})$ & $(\mathrm{mg} / \mathrm{L})$ & $(\mathrm{mg} / \mathrm{L})$ & $(\mathrm{mg} / \mathrm{L})$ & $(\mathrm{mg} / \mathrm{L})$ & $(\mathrm{mg} / \mathrm{L})$ & $(\mathrm{mg} / \mathrm{L})$ & $(\mathrm{mg} / \mathrm{L})$ \\
\hline $4 / 27 / 2001$ & 133.0 & $0.5^{\ddagger}$ & 0.5 & 12.2 & 13.9 & 2.1 & 3.9 & $0.01^{\dagger}$ & 0.05 & $0.005^{\dagger}$ & $0.003^{\dagger}$ \\
\hline $6 / 21 / 2001$ & 63.9 & $0.5^{\ddagger}$ & 0.7 & 16.3 & 12.5 & 2.2 & 2.7 & $0.01^{\dagger}$ & 0.03 & 0.12 & $0.003^{\dagger}$ \\
\hline $8 / 6 / 2001$ & 93.6 & $0.5^{\ddagger}$ & 8.3 & 4.5 & 8.6 & 3.4 & 5.9 & $0.01^{\dagger}$ & 0.02 & 0.02 & $0.003^{\dagger}$ \\
\hline $9 / 22 / 2001$ & 133.7 & $0.5^{\ddagger}$ & 0.9 & 26.8 & 18.6 & 2.7 & 5.6 & $0.01^{\dagger}$ & 0.01 & 0.02 & $0.003^{\dagger}$ \\
\hline $12 / 19 / 2001$ & 55.3 & & 0.4 & 6.6 & 4.7 & 0.9 & 1.6 & $0.01^{\dagger}$ & 0.13 & 0.02 & 0.034 \\
\hline $2 / 24 / 2002$ & 87.2 & 1.1 & 0.5 & 12.5 & 7.8 & 1.3 & 2.7 & $0.01^{\dagger}$ & 0.17 & $0.005^{\dagger}$ & 0.042 \\
\hline 4/5/2002 & 95.2 & 4.0 & 0.5 & 10.6 & 7.0 & 1.2 & 3.4 & $0.01^{\dagger}$ & 0.32 & 0.02 & 0.027 \\
\hline $6 / 27 / 2002$ & 157.0 & & 0.9 & 22.0 & 16.7 & 3.6 & 5.9 & $0.01^{\dagger}$ & 0.05 & 0.15 & 0.063 \\
\hline Average & 102.4 & 2.6 & 1.6 & 13.9 & 11.2 & 2.2 & 4.0 & 0.01 & 0.10 & 0.06 & 0.042 \\
\hline Min & 55.3 & 1.1 & 0.4 & 4.5 & 4.7 & 0.9 & 1.6 & 0.01 & 0.01 & 0.02 & 0.027 \\
\hline Max & 157.0 & 4.0 & 8.3 & 26.8 & 18.6 & 3.6 & 5.9 & 0.01 & 0.32 & 0.15 & 0.063 \\
\hline
\end{tabular}

$\dagger$ Value Used for Below Detection Limit (BDL) is recorded as half of the Detection Limit Value

\$ The Detection Limit Value for Chlorides before 5/10/2002 was equal to $1.00 \mathrm{mg} / \mathrm{L}$ for Mercuric Nitrate Buret Titration, Method 4500-CL- - C 
Table B-9a. Water Quality Grab Sample Data from BC-9.

\begin{tabular}{|c|c|c|c|c|c|c|c|c|c|}
\hline Sampling & Air & Water & Turbidity & Flow & pH & Conductivity & TSS & Alkalinity & Acidity \\
\hline Date & $\begin{array}{c}\text { Temp. } \\
\left({ }^{\circ} \mathrm{C}\right)\end{array}$ & $\begin{array}{c}\text { Temp. } \\
\left({ }^{\circ} \mathrm{C}\right)\end{array}$ & (NTU) & $\left(\mathrm{m}^{3} / \mathrm{sec}\right)$ & & (uS/cm) & $(\mathrm{mg} / \mathrm{L})$ & $\begin{array}{c}\mathrm{mg} / \mathrm{L} \text { as } \\
\mathrm{CaCO3}) \\
\end{array}$ & $\begin{array}{c}(\mathrm{mg} / \mathrm{L} \text { as } \\
\mathrm{CaCO3})\end{array}$ \\
\hline $3 / 8 / 2001$ & 0.4 & 0.3 & 22.0 & & 6.1 & 72.8 & 23.20 & 15.3 & 5.6 \\
\hline $4 / 27 / 2001$ & 16.0 & 15.1 & & & 6.4 & 146.0 & 7.92 & 16.4 & 4.7 \\
\hline $6 / 21 / 2001$ & 26.7 & 23.3 & 2.0 & 0.350 & 6.0 & 62.6 & 6.93 & 16.5 & 4.7 \\
\hline $8 / 6 / 2001$ & 23.3 & 19.2 & 8.0 & 0.777 & 5.8 & 127.7 & 10.00 & 14.0 & 4.0 \\
\hline $9 / 22 / 2001$ & 22.9 & 18.6 & 5.0 & 0.090 & 6.9 & 248.0 & 2.45 & 22.1 & 3.2 \\
\hline $12 / 19 / 2001$ & 10.6 & 4.9 & 5.0 & 1.409 & 5.9 & 135.4 & 2.45 & 15.7 & 6.8 \\
\hline $2 / 24 / 2002$ & 13.6 & 1.6 & 7.0 & 0.636 & 5.7 & 137.0 & 9.25 & 16.4 & 10.0 \\
\hline $4 / 5 / 2002$ & 0.1 & 4.3 & & 1.266 & 5.2 & 127.1 & 6.40 & 17.6 & 5.2 \\
\hline $6 / 27 / 2002$ & 19.8 & 22.8 & 6.0 & 0.348 & 6.4 & 223.8 & 3.65 & 19.0 & 3.4 \\
\hline Average & 14.8 & 12.2 & 7.9 & 0.697 & 6.0 & 142.3 & 8.03 & 17.0 & 5.3 \\
\hline Min & 0.1 & 0.3 & 2.0 & 0.090 & 5.2 & 62.6 & 2.45 & 14.0 & 3.2 \\
\hline $\operatorname{Max}$ & 26.7 & 23.3 & 22.0 & 1.409 & 6.9 & 248.0 & 23.20 & 22.1 & 10.0 \\
\hline
\end{tabular}

$\dagger$ Value Used for Below Detection Limit (BDL) is recorded as half of the Detection Limit Value

\$ The Detection Limit Value for Chlorides before 5/10/2002 was equal to $1.00 \mathrm{mg} / \mathrm{L}$ for Mercuric Nitrate Buret

Titration, Method 4500-CL - C 
Table B-9b. Water Quality Grab Sample Data from BC-9.

\begin{tabular}{|c|c|c|c|c|c|c|c|c|c|c|c|}
\hline Sampling & Sulfate & Chloride & Iron & Calcium & Magnesium & Manganese & Aluminum & Nitrite & Nitrate & Ammonia & Phosphate \\
\hline Date & $(\mathrm{mg} / \mathrm{L})$ & $(\mathrm{mg} / \mathrm{L})$ & $(\mathrm{mg} / \mathrm{L})$ & $(\mathrm{mg} / \mathrm{L})$ & $(\mathrm{mg} / \mathrm{L})$ & $(\mathrm{mg} / \mathrm{L})$ & $(\mathrm{mg} / \mathrm{L})$ & $(\mathrm{mg} / \mathrm{L})$ & $(\mathrm{mg} / \mathrm{L})$ & $(\mathrm{mg} / \mathrm{L})$ & $(\mathrm{mg} / \mathrm{L})$ \\
\hline $3 / 8 / 2001$ & 48.0 & 8.0 & 0.3 & 15.2 & 4.0 & & 0.1 & $0.01^{\dagger}$ & 0.26 & 0.52 & 0.050 \\
\hline $4 / 27 / 2001$ & 50.0 & 3.0 & 0.6 & 12.5 & 4.8 & 0.7 & 0.2 & $0.01^{\dagger}$ & 0.33 & 0.56 & $0.003^{\dagger}$ \\
\hline $6 / 21 / 2001$ & 48.0 & 2.0 & 0.3 & 15.8 & 6.3 & 0.8 & 0.1 & $0.01^{\dagger}$ & 0.27 & 0.11 & $0.003^{\dagger}$ \\
\hline $8 / 6 / 2001$ & 42.0 & $0.5^{\ddagger}$ & 1.2 & 9.4 & 3.5 & 0.5 & 0.4 & $0.01^{\dagger}$ & 0.20 & 0.16 & 0.005 \\
\hline 9/22/2001 & 71.0 & 3.0 & 0.6 & 29.7 & 8.7 & 0.5 & 0.1 & $0.01^{\dagger}$ & 0.64 & 0.45 & $0.003^{\dagger}$ \\
\hline $12 / 19 / 2001$ & 47.0 & & 0.8 & 8.3 & 3.0 & 0.5 & 3.5 & $0.01^{\dagger}$ & 0.30 & 1.34 & 0.017 \\
\hline $2 / 24 / 2002$ & 50.0 & 8.0 & 0.8 & 10.2 & 3.2 & 0.5 & 0.6 & $0.01^{\dagger}$ & 0.18 & 1.51 & 0.013 \\
\hline 4/5/2002 & 46.0 & 4.0 & 0.7 & 8.4 & 3.5 & 0.5 & 0.9 & $0.01^{\dagger}$ & 0.27 & 0.43 & 0.005 \\
\hline $6 / 27 / 2002$ & 88.0 & & 0.5 & 20.7 & 6.3 & 0.5 & 0.2 & $0.01^{\dagger}$ & 0.65 & 0.16 & 0.022 \\
\hline Average & 54.4 & 4.7 & 0.6 & 14.5 & 4.8 & 0.6 & 0.7 & 0.01 & 0.34 & 0.58 & 0.019 \\
\hline Min & 42.0 & 2.0 & 0.3 & 8.3 & 3.0 & 0.5 & 0.1 & 0.01 & 0.18 & 0.11 & 0.005 \\
\hline $\operatorname{Max}$ & 88.0 & 8.0 & 1.2 & 29.7 & 8.7 & 0.8 & 3.5 & 0.01 & 0.65 & 1.51 & 0.050 \\
\hline
\end{tabular}

$\dagger$ Value Used for Below Detection Limit (BDL) is recorded as half of the Detection Limit Value

\$ The Detection Limit Value for Chlorides before 5/10/2002 was equal to $1.00 \mathrm{mg} / \mathrm{L}$ for Mercuric

Nitrate Buret Titration, Method 4500-CL - C 